11.

19. Engbersen, E. Snel eg
A. A. Weltevrede

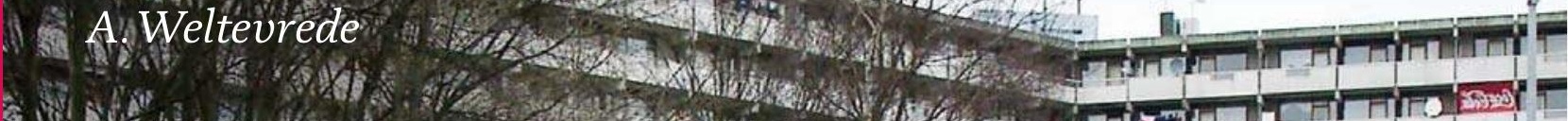

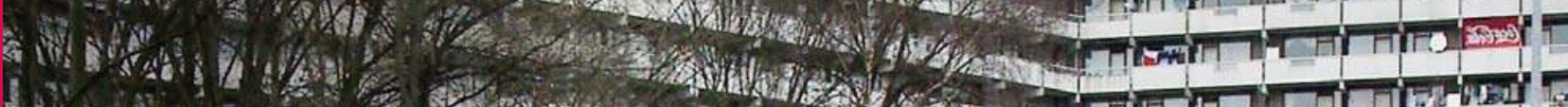

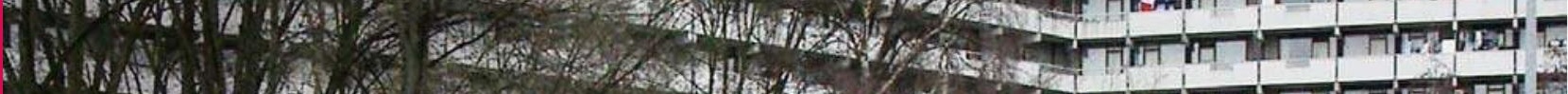

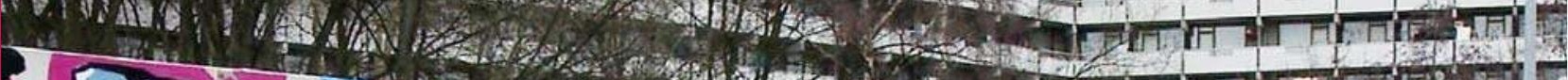

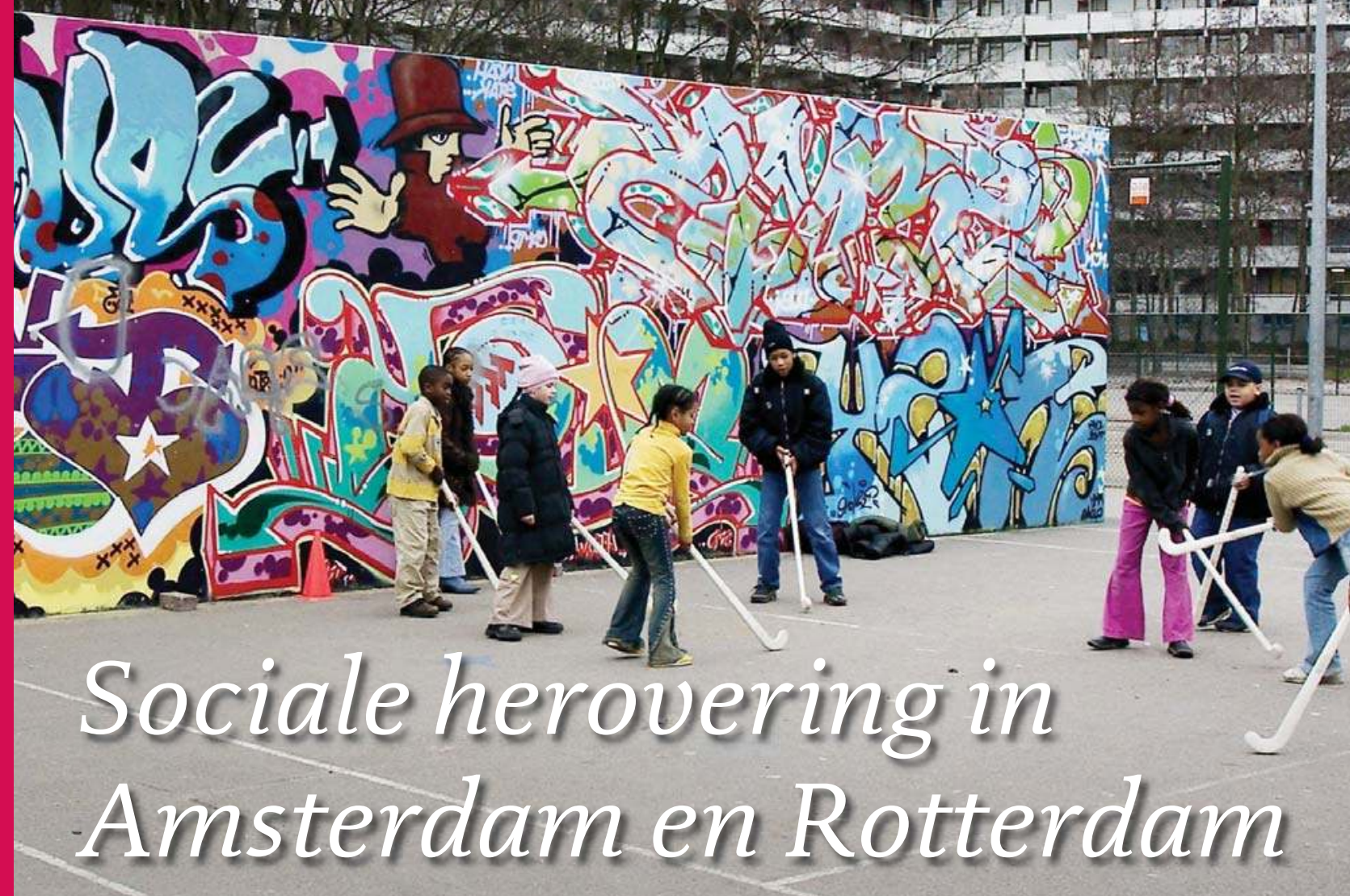

ÉÉN VERHAAL OVER TWEE WIJKEN 
Sociale herovering in Amsterdam en Rotterdam 
De serie 'Verkenningen' omvat studies die in het kader van de werkzaamheden van de WRR tot stand zijn gekomen en naar zijn oordeel van zodanige kwaliteit en betekenis zijn, dat publicatie gewenst is. De verantwoordelijkheid voor de inhoud en de ingenomen standpunten berust bij de auteurs.

Lange Vijverberg 4-5

Postbus 20004

2500 EA 's-Gravenhage

Telefoon 070-356 46 oo

Telefax 070-356 4685

E-mail info@wrr.nl

Website http://www.wrr.nl 


\section{Sociale herovering in Amsterdam en Rotterdam}

ÉÉN VERHAAL OVER TWEE WIJKEN

Godfried Engbersen, Erik Snel en Afke Weltevrede Erasmus Universiteit Rotterdam/Universiteit Twente 
Omslagfoto: Patrick Post/Hollandse Hoogte

Omslagontwerp: Studio Daniëls, Den Haag

Vormgeving binnenwerk: Het Steen Typografie, Maarssen

ISBN 9053567364

NUR 741

(C) WRR/Amsterdam University Press, Den Haag/Amsterdam 2005

Alle rechten voorbehouden. Niets uit deze uitgave mag worden verveelvoudigd, opgeslagen in een geautomatiseerd gegevensbestand, of openbaar gemaakt, in enige vorm of op enige wijze, hetzij elektronisch, mechanisch, door fotokopieën, opnamen of enige andere manier, zonder voorafgaande schriftelijke toestemming van de uitgever.

Voor zover het maken van kopieën uit deze uitgave is toegestaan op grond van artikel 16B Auteurswet $1912 j^{\circ}$ het Besluit van 20 juni 1974, Stb. 351, zoals gewijzigd bij het Besluit van 23 augustus 1985, Stb. 471 en artikel 17 Auteurswet 1912, dient men de daarvoor wettelijk verschuldigde vergoedingen te voldoen aan de Stichting Reprorecht (Postbus 3051, 2130 KB Hoofddorp). Voor het overnemen van gedeelte(n) uit deze uitgave in bloemlezingen, readers en andere compilatiewerken (artikel 16 Auteurswet 1912) dient men zich tot de uitgever te wenden. 


\section{WOORD VOORAF}

De buurt doet er toe bij de aanpak van een groot aantal problemen die van invloed zijn op de leefbaarheid - althans: ze kan ertoe doen als het sociale potentieel dat op kleinschalige niveaus aanwezig is, voldoende ruimte en ruggesteun krijgt. In buurten die goed 'draaien', groeit de hoeveelheid beschikbaar sociaal kapitaal sneller dan waar sociale reserves geheel zijn uitgeput. Daar waar wederzijdse betrokkenheid bestaat, kunnen mensen op eigen initiatief en op maat ondersteund door de overheid en sociale spelers zoals woningcorporaties, politie, welzijnswerk, het nodige aan. Deze notie staat centraal in het rapport Vertrouwen in de buurt, dat de Wetenschappelijke Raad voor het Regeringsbeleid ook in het voorjaar 2005 uitbrengt. De raad tekent daarbij wel aan dat er een grote variëteit in buurten en problematieken bestaat. Vooral veel achterstandsbuurten kennen hardnekkige en omvangrijke problemen (grote doorstroming, lage inkomens, slechte huisvesting), waardoor die buurten zonder gerichte aandacht en ondersteuning moeilijk op eigen kracht de probleemspiralen kunnen doorbreken. In dit soort buurten past een strategie van 'sociale herovering' - dat wil zeggen: een massieve inzet van alle betrokkenen om de leefbaarheid te verbeteren - alvorens er weer een eigen sociaal kapitaal kan worden opgebouwd, zodat er in de buurt voldoende veerkracht en initiatief kan zijn om problemen te voorkomen en aan te pakken.

Ter onderbouwing van de specifieke problematiek van achterstandsbuurten in de grote steden heeft de WRR een onderzoek laten uitvoeren door prof. G. Engbersen, prof. E. Snel en mw. A. Weltevrede (Erasmus Universiteit Rotterdam en Universiteit van Twente). Het verslag van dat onderzoek (Sociale herovering in Amsterdam en Rotterdam) ondersteunt mede het rapport Vertrouwen in de buurt. Vanwege de hoge kwaliteit en de uitgesproken maatschappelijke en beleidsmatige relevantie ervan maakt de WRR deze studie graag beschikbaar voor een breed publiek van geïnteresseerden. Een groot aantal respondenten heeft bijgedragen aan de interessante inzichten die in deze studie naar voren komen. De raad is de auteurs van de studie, de respondenten en de instituties die gegevens en informatie beschikbaar hebben gesteld erkentelijk voor hun bijdrage. Naast de studie die in deze Verkenning is opgenomen, is ook het eigen veldonderzoek (een 28-tal good practices) voor het rapport Vertrouwen in de buurt via de website van de WRR als webpublicatie beschikbaar gesteld:

Hazeu, C.A., N.G.J. Boonstra, M. Jager-Vreugdenhil en P. Winsemius (2005) Buurtinitiatieven en buurtbeleid in Nederland anno 2004. Analyse van een veldonderzoek van 28 casussen, www.wrr.nl, Den Haag: WRR.

Prof. dr. W.B.H.J. van de Donk

Voorzitter WRR 


\section{INHOUDSOPGAVE}

I Centrale bevindingen: sociale herovering in Amsterdam en Rotterdam; één verhaal over twee wijken

1.1 Inleiding

1.2 Macrostructurele ontwikkelingen in Amsterdam en Rotterdam i1

1.3 De twee onderzoeksbuurten: Overtoomse Veld en de Tarwewijk 13

1.4 Sociale herovering in Amsterdam en Rotterdam 19

$\begin{array}{ll}1.5 & \text { Indeling van deze studie }\end{array}$

1.6 Methodische verantwoording 22

2 Macrostructurele ontwikkelingen in Amsterdam en

Rotterdam 25

2.1 Visies op stedelijke ontwikkeling 25

2.2 Het ontstaan van multiculturele steden en buurten 26

$2.3 \quad$ Postindustriële stedelijke economieën? 29

2.4 Spanningen op de stedelijke woningmarkt 32

$\begin{array}{ll}2.5 & \text { Overlast en criminaliteit }\end{array}$

3 Onderzoeksbuurt Overtoomse Veld 43

3.1 De buurt: achtergrond en bewoners 43

$\begin{array}{lll}3.2 & \text { Bewoners en professionals over de buurt } & 45\end{array}$

3.3 De belangrijkste problemen in de buurt 46

3.3.1 Leefbaarheid en veiligheid 46

3.3.2 Woningvoorraad en stedelijke herstructurering 51

3.3.3 Onderwijsachterstand en schooluitval 54

3.3.4 Werkloosheid en uitkeringsafhankelijkheid 58

$\begin{array}{lll}3.4 & \text { Discussie } & 60\end{array}$

$4 \quad$ Onderzoeksbuurt de Tarwewijk $\quad 65$

$\begin{array}{ll}\text { 4.1 De buurt: achtergrond en bewoners } & 65\end{array}$

4.2 De belangrijkste problemen in de buurt 68

4.2.1 Leefbaarheid en veiligheid in de buurt 68

4.2.2 Woningvoorraad en stedelijke herstructurering 72

4.2.3 Onderwijsachterstand en schooluitval 75

4.2.4 Werkloosheid en uitkeringsafhankelijkheid 78

\begin{tabular}{ll}
4.2 .5 & Overige problemen \\
\hline 2
\end{tabular}

4.3 Discussie $\quad 84$

$5 \quad$ De herontdekking van de Tarwewijk $\quad 89$

$\begin{array}{ll}5.1 \quad \text { Inleiding } & 89\end{array}$

5.2 Van 'Nieuw Rotterdam' naar 'Rotterdam in balans' $\quad 89$

5.3 De herontdekking en herovering van de Tarwewijk 91

5.3.1 Het transparant maken van de wijk 92 
5.3.2 Buurtinterventies 94

5.3.3 Vitale coalities en integrale samenwerking 97

5.3.4 Voorbij het wijkniveau 99

$\begin{array}{lll}5.4 & \text { Discussie } & 100\end{array}$

6 Buurtregie in Overtoomse Veld 105

$\begin{array}{lll}6.1 & \text { Inleiding } & 105\end{array}$

$\begin{array}{lll}6.2 & \text { Het transparant maken van de wijk } & 107\end{array}$

$\begin{array}{lll}6.3 & \text { Buurtinterventies } & 114\end{array}$

6.4 Vitale coalities, integraal werken en ketenaanpak 118

$\begin{array}{ll}6.5 & \text { Schaalniveaus } \\ 6.6 & 123\end{array}$

$\begin{array}{lll}6.6 & \text { Discussie } & 123\end{array}$

$7 \quad$ Samenvatting en discussie $\quad 125$

$\begin{array}{lll}7.1 & 125\end{array}$

$\begin{array}{ll}7.2 & \text { Sociale herovering in Amsterdam en Rotterdam } \\ 7.325\end{array}$

$\begin{array}{lll}7 \cdot 3 & \text { Discussie } & 127\end{array}$

$\begin{array}{ll}\text { Literatuur } & 129\end{array}$

$\begin{array}{ll}\text { Bijlage: Lijst respondenten } & 133\end{array}$ 
Deze studie gaat over de grenzen en mogelijkheden van grootstedelijke gebieden om zichzelf te vernieuwen en te verbeteren. $Z e$ is gebaseerd op een vergelijking van stedelijke aanpakken zoals die momenteel plaatsvinden in Amsterdam en Rotterdam, in het bijzonder de buurt Overtoomse Veld in Amsterdam-West en de Tarwewijk in Rotterdam-Zuid. De vraag naar het zelfvernieuwend potentieel van buurten en wijken is een aloude vraag. Ze werd opgeworpen door J.A.A. van Doorn die in 1955 een preadvies schreef Wijk en stad: reële integratiekaders?, maar ze keert ook voortdurend terug in contemporaine debatten over sociale vernieuwing, het grotestedenbeleid en de opkomst van diverse leefbaarheidspartijen bij de gemeenteraadsverkiezingen in maart 2002.

In dit rapport zal de vraag naar de wijk als integratiekader overigens niet centraal staan. Die vraag lijkt afdoende beantwoord: moderne sociale relaties zijn wijken buurtoverstijgend (vgl. Blokland-Potters 1998; Duyvendak en Hurenkamp 2004). De wijk levert één mogelijk kader tot integratie, naast vele andere maatschappelijke sferen (Komter et al. 2000; Engbersen en Gabriëls 1995). Die andere maatschappelijke sferen (arbeid, onderwijs, religie, staatsburgerschap, et cetera) zijn veelal van groter belang dan wijk- of buurtgebonden relaties en activiteiten (Bauman 2001). Daarmee mag de betekenis van de wijk enigszins zijn gerelativeerd, onbelangrijk is zij niet.

Wie meent dat wijk en buurt niet meer belangrijk zijn gaat voorbij aan de realiteit dat voor heel veel mensen de keuze waar zij gaan wonen een heel fundamentele is. De kwaliteit van de dagelijkse woonomgeving wordt door iedereen als heel belangrijk beschouwd (Fischer et al. 1996: 83). Weinig mensen hebben echter de mogelijkheid om hun woonomgeving geheel naar eigen wensen en inzichten te kiezen. Financiële beperkingen begrenzen de woonkeuzes van mensen. Dat geldt in het bijzonder voor de bewoners van stedelijke gebieden waar wij nader verslag van zullen doen in deze studie. Het zijn gebieden waar vooral lage inkomensgroepen wonen (waaronder veel eerste en tweede generatie migranten), waar de doorstroomsnelheid zeer groot is, maar waar ook veel mensen woonachtig zijn die niet in staat zijn de wijk te verlaten. In deze wijken heeft zich een proces afgespeeld dat al door de sociologen van de 'Chicago-school' in de jaren twintig voor de Verenigde Staten is geschetst. De komst van migranten werd door de zittende bevolking gezien als een teken van verval en versterkte de trek naar buiten. Stadsvernieuwing, zeker als dat renovatie betekende, kon dat proces niet tot staan brengen. Degenen die het zich konden veroorloven, trokken naar 'betere' buurten. Zij die bleven, waren niet zelden de eerste slachtoffers van automatisering of reallocatie van industriële productieprocessen; zij raakten werkloos of werden 
afgekeurd. De autochtone bewoners die nu nog woonachtig zijn in oude voor- en naoorlogse wijken bestaan voor een deel uit achterblijvers: mensen die om de een of andere reden de sprong naar een betere buurt niet hebben gemaakt. Doordat de financiële horizon van deze mensen aanmerkelijk minder wijds werd, nam ook hun geografische reikwijdte af. In de Amerikaanse literatuur worden zij the trapped genoemd. De waarden en normen die zij zich eigen hadden moeten maken in het beschavingsoffensief waarvan zij en hun ouders het object waren geweest, worden in hun ogen door de nieuwe bewoners vaak met voeten getreden (Burgers en Engbersen 1994).

Het onbehagen in vooroorlogse en naoorlogse wijken heeft niet alleen te maken met de vestiging van omvangrijke aantallen migranten, maar ook met problemen van leefbaarheid en veiligheid. Deze vraagstukken zijn niet louter te herleiden tot de komst en vestiging van migranten. Ze hebben betrekking op praktijken van huisjesmelkers, illegale bewoning, drugsoverlast, de aanwezigheid van dak- en thuislozen, rondhangende jongeren en op de verloedering van de publieke ruimte die in de jaren tachtig en negentig heeft plaatsgevonden. Tegen deze problemen is lange tijd op een relatief lankmoedige wijze opgetreden. Het zou onjuist zijn om te beweren dat ze niet eerder zijn herkend en beschreven, maar we zien vooral na de opkomst van Pim Fortuyn en de gemeenteraads- en landelijke verkiezingen in 2002 een hernieuwde aandacht voor de situatie in achterstandswijken. Politici worden aangemoedigd om massaal de wijk in te gaan om de kloof tussen burger en politiek te herstellen en hun verloren gezag weer terug te winnen. Zo raakt een ieder weer in de ban van de buurt (Sprinkhuizen et al. 1998).

Het zou ook onjuist zijn om te stellen dat de aandacht voor wijk en buurt van zeer recente datum is. In de eerste periode van het grotestedenbeleid (1996-1999) was de wijkgerichte aanpak al een centraal thema. Deze fascinatie voor buurten en wijken wordt wetenschappelijk begeleid door de actuele aandacht voor de betekenis van de civil society voor vraagstukken van democratie en leefbaarheid. Auteurs als Putman (200o) en Fukuyama (1996) wijzen erop dat landen, staten of regio's zich van elkaar onderscheiden naar de mate waarin burgers in staat zijn zich (vrijwillig) te organiseren voor politieke, economische en altruïstische doelen. Gemeenschappen met een bloeiende civil society (maatschappelijk middenveld) zouden zich kenmerken door een hoogontwikkeld 'sociaal kapitaal', terwijl gemeenschappen met een verschraalde civil society zich kenmerken door een gering 'sociaal kapitaal'. Sociaal kapitaal heeft enerzijds betrekking op de hulpbronnen (contacten, informatie, geld, steun) die mensen weten te destilleren uit de sociale verbanden waar zij deel van uitmaken en heeft anderzijds betrekking op het bestaan van onderling vertrouwen waardoor mensen in staat zijn zich te organiseren en samen te werken. Putnam (2000) gebruikt in dit verband het bekende onderscheid tussen bonding en bridging. Wil sociaal kapitaal bewoners vooruit helpen, dan dienen bruggen geslagen te worden naar mensen van buiten de eigen sociale groep. Kwetsbare groepen in kwetsbare wijken hebben - in meer of mindere mate - de beschikking over ondersteunende netwerken van lotgenoten (bonding), maar zijn echter niet in staat om de bruggen (bridging) te slaan 
naar andere sociale groepen waardoor hun sociaal isolement wordt bestendigd (Engbersen 2003).

De Amsterdamse en Rotterdamse wijken die in deze studie centraal staan, kenmerken zich door een gering sociaal kapitaal. Dat is een gevolg van de snelle doorstroom van bewoners en de zeer grote etnische diversiteit binnen deze wijken, alsmede van de lage inkomenspositie van veel bewoners. Deze constatering roept de vraag op in hoeverre stedelijke vernieuwing van onderop mogelijk is. In deze studie zal worden betoogd dat de sociale vraagstukken die spelen in Amsterdam en Rotterdam van een dusdanige orde zijn dat, naast het ondersteunen van daadkrachtige bewoners, vooral ook andere partijen die vernieuwing dienen te realiseren. Buitenmaatse problemen vragen om een veelomvattende aanpak van indringende wijkgerichte interventies en een bovenstedelijk huisvestings- en vestigingsbeleid. Een dergelijke veelomvattend aanpak dient toegesneden te zijn op het specifieke karakter van steden en wijken. In deze studie komen derhalve ook de verschillen tussen Amsterdam en Rotterdam aan de orde.

\subsection{MACROSTRUCTURELE ONTWIKKELINGEN IN AMSTERDAM EN ROTTERDAM}

In hoofdstuk 2 wordt een beschrijving gegeven van vier macrostructurele factoren die sterk bepalend zijn voor de stedelijke ontwikkelingen in Amsterdam en Rotterdam. De eerste is het proces van voortschrijdende (selectieve) migratie. Het gevolg daarvan is dat binnen afzienbare tijd 'etnische minderheden' (dat wil zeggen eerste en tweede generatie migranten afkomstig uit niet-westerse landen) de meerderheid van de stadsbevolking zullen vormen. In Amsterdam staat dit rond 2030 te gebeuren, in Rotterdam al rond 2017. Deze verkleuring van de stad heeft niet alleen te maken met de instroom van migranten (met name in het kader van familiemigratie), maar ook met de uitstroom van autochtone bewoners naar de randgemeenten. De verwachting is dat in de periode 2003-2020 in beide steden het aantal autochtonen met zo'n 45.000 tot 50.000 zal verminderen (Gemeente Amsterdam, Dienst O\&S en Gemeente Rotterdam, Centrum voor Onderzoek en Statistiek).

Een tweede factor heeft betrekking op het functioneren van de stedelijke economie. De Amsterdamse en Rotterdamse arbeidsmarkten verschillen van elkaar. Ten eerste is de tendens tot postindustrialisering van de arbeidsmarkt in Amsterdam verder voortgeschreden dan in Rotterdam. Ten tweede zijn er verschillen in het niveau van de postindustriële beroepen. In Amsterdam is sprake van een zekere polarisatie van de arbeidsmarkt, vooral in de sfeer van postindustriële beroepen. Dat wil zeggen dat zowel het aandeel personen met een hooggeschoold beroep als met een laag- of ongeschoold beroep is gestegen. De Amsterdamse arbeidsmarkt zal in de toekomst naar alle waarschijnlijkheid sterker in het teken van polarisatie komen te staan. In Rotterdam is de situatie anders. Daar zien we ook een groeiend aandeel postindustriële beroepen, maar vrijwel alleen in de onderste regionen van de arbeidsmarkt. Het Rotterdamse gezicht van polarisatie 
betreft de groeiende tegenstelling tussen enerzijds de nog in Rotterdam wonende beroepsbevolking - die vooral is aangewezen op laaggeschoold werk in de dienstensector en de resterende industrie - en anderzijds de in de omliggende randgemeenten wonende middengroepen en elite die hoogwaardige functies innemen in de Rotterdamse economie. Voor beide stedelijke arbeidsmarkten geldt echter dat zij onvoldoende banen genereren voor de inwoners van Amsterdam en Rotterdam. In de jaren negentig mag het aantal uitkeringsgerechtigden in beide steden fors gedaald zijn, nog altijd herbergen beide steden substantiële aantallen uitkeringsafhankelijken. Wie de cijfers over uitkeringsafhankelijkheid in Amsterdam en Rotterdam op een rij zet, ziet dat er ook op dit punt weinig verschillen zijn tussen beide steden. In zowel Amsterdam als Rotterdam leefde in 2002 iets meer dan 19 procent van alle bewoners in de werkzame leeftijd (15-64 jaar) van een uitkering, anderhalf maal zoveel als landelijk gemiddeld. In Rotterdam zijn er wat meer bijstandsontvangers dan elders, in Amsterdam en in de rest van Nederland zijn er daarentegen verhoudingsgewijs meer arbeidsongeschikten (WAO, WAZ en Wajong) dan in Rotterdam.

Een derde factor heeft betrekking op de stedelijke woningvoorraad. Die van de grote steden bestaat veel meer dan landelijk gemiddeld uit sociale woningbouw, uit goedkope woningen, uit flats en portiekwoningen en uit oudere woningen. Hierdoor oefenen de grote steden een grote aantrekkingskracht uit op werklozen en lage inkomensgroepen die huisvesting kunnen krijgen tegen een relatief redelijke prijs. In de tweede plaats bieden de steden hierdoor mogelijkheden voor immigranten en andere starters om op de woningmarkt relatief goedkope woonruimte te vinden. De woningvoorraad in Amsterdam en Rotterdam verschilt overigens niet fundamenteel van elkaar wanneer deze wordt afgemeten aan de prijsklasse van woningen. De gangbare veronderstelling is dat in Amsterdam het aandeel duurdere woningen substantieel hoger is dan in Rotterdam. Dit blijkt echter niet het geval te zijn. In Rotterdam is het middensegment van de woningvoorraad (huur én koop) wat groter dan in Amsterdam, terwijl in Amsterdam zowel de onderkant als de bovenkant van de woningmarkt iets groter is dan in Rotterdam. Wel is er een groot verschil in woonmilieus. Amsterdam kent veel meer gewilde woonmilieus in en rond het centrum dan Rotterdam. Beide steden proberen inmiddels om via een beleid van stedelijke herstructurering de woningvoorraad meer divers te maken, om zodoende de uitstroom van middengroepen uit de stad tegen te gaan.

Een vierde factor heeft betrekking op vraagstukken van leefbaarheid en veiligheid. In Nederland was het criminaliteitsniveau in de periode 1990-200o redelijk stabiel. De vermogenscriminaliteit is afgenomen, terwijl de geweldscriminaliteit en de vernielingen toenamen (SCP 2002: 217). Recentelijk lijkt de criminaliteit weer wat toe te nemen. Kijken we naar Amsterdam en Rotterdam, dan ligt het criminaliteitsniveau in de eerste stad circa 20 procent hoger dan in de tweede. Wel is de ontwikkeling in het aantal delicten in beide steden anders. In Amsterdam loopt het aantal delicten de laatste jaren (in de periode 2000-2002) geleide- 
lijk terug, terwijl in Rotterdam in dezelfde periode juist een toename van het aantal delicten per duizend inwoners plaatsvindt. Voor beide steden geldt verder dat er een sterke stijging is van geweldsdelicten en van vernielingen en openbare ordedelicten.

Deze vier factoren - selectieve migratieprocessen, stedelijke arbeidsmarkten, een historisch gegroeide woningvoorraad en ontwikkelingen in criminaliteitsniveau - zijn van buurtoverstijgende en deels van landoverstijgende aard. Ze hebben echter wel ingrijpende gevolgen voor de maatschappelijke positie van bewoners en de ontwikkelingskansen van specifieke stedelijke gebieden. Dat blijkt ook als we de situatie in ogenschouw nemen in de buurt Overtoomse Veld in het stadsdeel Slotervaart in Amsterdam-West en in de buurt Tarwewijk in de Rotterdamse deelgemeente Charlois. Deze stedelijke gebieden zijn door ons geselecteerd om twee redenen. Ten eerste omdat zij inzicht geven in de aard, omvang en hardheid van sociale vraagstukken zoals die op buurt-, wijk- en deelraadsniveau spelen in de twee grote steden van Nederland. Ten tweede omdat in beide gebieden in de afgelopen jaren diverse nieuwe initiatieven zijn ontwikkeld om de situatie te verbeteren. Voordat wij verslag doen van de aanpakken zoals die daar plaatsvinden, geven we een korte analyse van de stedelijke ontwikkeling en problemen in beide gebieden. Daarbij gaan we ook nader in op verschillen tussen Amsterdam en Rotterdam.

\subsection{DE TWEE ONDERZOEKSBUURTEN: OVERTOOMSE VELD EN DE TARWEWIJK}

In deze paragraaf proberen we een aantal zaken op een rij te zetten. In hoeverre is de sociale problematiek in buurten als het Rotterdamse Tarwewijk en het Amsterdamse Overtoomse Veld vergelijkbaar? Of is de problematiek in de ene buurt en stad van een heel andere orde dan in de andere buurt en stad? We vatten hier de centrale bevindingen samen van onze beschrijvingen van beide steden en buurten in de hoofdstukken 2 tot en met 4 van dit rapport. Overigens moeten we er wel bij melden dat deze vergelijking soms erg moeilijk is door een gebrek aan vergelijkbare cijfermatige gegevens over beide steden en buurten. Daarnaast proberen we in deze paragraaf verder te gaan dan het enkel presenteren van cijfers, we gaan tenslotte in op enkele achtergronden van de uiteenlopende ontwikkelingen in Amsterdam en Rotterdam zoals die hierboven zijn geduid (zie paragraaf 1.2).

\section{Bevolkingsopbouw}

De bevolkingsopbouw is in de onderzochte gebieden sterk veranderd. Anno 2004 is ruim 70 procent van de bewoners van de Tarwewijk van allochtone afkomst (in de deelgemeente Charlois waar de Tarwewijk deel van is, is dit 50\%). Daaronder bevinden zich vooral mensen uit het Caribische gebied (Surinamers en Antillianen), maar ook groepen Kaapverdianen, Marokkanen en asielmigranten. In Overtoomse Veld is eveneens 70 procent van de bewoners van allochtone afkomst (het stadsdeelpercentage is 50\%). Daarbinnen zijn vooral Marokkanen 
en in mindere mate Turken en Surinamers vertegenwoordigd. In beide gebieden vindt een sterke instroom plaats via patronen van huwelijksmigratie.

\section{Veiligheid}

Misschien wel het meest urgente probleem in de hedendaagse grote steden is de veiligheid. In ieder geval neemt in het politieke debat de overmaat aan overlast en criminaliteit in de steden, met name in die stadsbuurten waar verloedering dreigt, een prominente plaats in. Uit beschikbare gegevens blijkt dat de onveiligheid ongelijk verdeeld is in ons land. In de grote steden ligt het aantal delicten verhoudingsgewijs veel hoger dan landelijk gemiddeld. Zo ligt het totale aantal delicten per duizend inwoners in Rotterdam en Amsterdam respectievelijk 1,4 en 1,7 maal zo hoog als landelijk gemiddeld. Met name geweldsmisdrijven komen verhoudingsgewijs vaker in de grote steden voor dan elders in Nederland. Als men de situatie tussen de beide steden onderling vergelijkt, kan gezegd worden dat de criminaliteit (althans gemeten naar het aantal formeel bij de politie geregistreerde delicten per duizend inwoners) in Rotterdam ongeveer 20 procent lager ligt dan in Amsterdam. Dit geldt voor vrijwel alle delicten, behalve voor vernieling en openbare orde. Deze laatste delictsoort komt in Rotterdam verhoudingsgewijs even vaak voor als in Amsterdam.

Maar ook binnen de stad is de onveiligheid ongelijk verdeeld. Al vele studies hebben uitgewezen dat de overlast en criminaliteit in grootstedelijke achterstandswijken beduidend hoger ligt dan gemiddeld in de stad. Er bestaat veelal een sterk verband tussen de mate van sociale deprivatie in een buurt, het aandeel minderheden onder de buurtbevolking en de mate van geregistreerde criminaliteit (Van der Leun et al. 1998). Dit geldt ook wanneer we naar de situatie in onze beide onderzoeksbuurten in Amsterdam en Rotterdam kijken. De geregistreerde criminaliteit (gemeten naar het aantal delicten per duizend inwoners) ligt in de buurt Overtoomse Veld een fractie hoger dan gemiddeld in Amsterdam. Het maakt hierbij niet veel uit naar welke delictsoort men kijkt. Overigens ligt het aantal delicten in het Amsterdamse stadsdeel Slotervaart lager dan gemiddeld in de stad, vooral omdat dit stadsdeel ook wat betere wijken met relatief weinig criminaliteit kent. In Rotterdam valt vooral op hoe weinig verschil er is tussen de veiligheidssituatie in de Tarwewijk, de deelgemeente Charlois en in Rotterdam gemiddeld. In Tarwewijk ligt het aantal delicten per duizend inwoners zelfs nog iets lager dan gemiddeld in de stad.

Deze bevinding dat de geregistreerde criminaliteit in 'erkende probleemwijken' als Overtoomse Veld of Tarwewijk slechts weinig of zelfs helemaal niet hoger ligt dan gemiddeld in de stad lijkt op het eerste gezicht opmerkelijk, maar is dat bij nader inzien niet. Veel delicten vinden immers plaats in de winkel- en uitgaanscentra van de stad, en die criminaliteit trekt de stedelijke gemiddelden aardig omhoog. Vergelijken we tenslotte het aantal delicten per duizend inwoners in de Rotterdamse Tarwewijk en in Charlois met de situatie in respectievelijk Overtoomse Veld en Slotervaart, dan blijkt aan de ene kant dat de formeel geregistreerde criminaliteit in de buurt Overtoomse Veld beduidend hoger ligt dan 
in de Tarwewijk, terwijl op stadsdeelniveau de criminaliteit in Charlois verhoudingsgewijs wat hoger ligt dan gemiddeld in Slotervaart (omdat Slotervaart, zoals gezegd, ook buurten met verhoudingsgewijs weinig criminaliteit kent).

\section{Leefbaarheid}

Los van de feitelijke criminaliteit (delicten) zijn er in stadsbuurten zoals Tarwewijk en Overtoomse Veld grote problemen op het gebied van leefbaarheid, die in politieke discussies steeds worden benadrukt. De leefbaarheid van een buurt wordt sterk bepaald door de mate waarin buurtbewoners zich prettig en veilig voelen in de openbare ruimte. Verschijnselen als rondhangende jongeren op straat, rondscheurende scooters, drugspanden, prostitutie op straat, enzovoort, vormen een bedreiging voor de leefbaarheid in een buurt. Ook als bewoners niet direct slachtoffer van een delict worden, voelen ze zich door deze verschijnselen steeds minder thuis in de buurt tot het moment dat ze - als ze dat kunnen betalen - de verhuiswagen laten voorrijden om te vertrekken. De trek uit de buurt versterkt echter de leefbaarheidsproblemen weer. Als veel mensen vertrekken en weinig mensen lang in de buurt blijven wonen, gaat dat ten koste van de sociale cohesie in buurten en van de mate waarin bewoners zelf bij machte zijn om het leefklimaat in de buurt naar hun hand te zetten.

Een wijk als de Tarwewijk in de Rotterdamse deelgemeente Charlois is landelijk bekend als een wijk met grote leefbaarheidsproblemen. Bewoners uit deze wijk klagen over vervuiling, drugsoverlast, overlast door jongeren en wat al niet. Uit een veiligheidsenquête onder bewoners in Charlois waar de Tarwewijk deel van is, blijkt dat slechts 59 procent van de bewoners tevreden is met de eigen buurt, in Rotterdam is gemiddeld 74 procent van de bewoners tevreden. De vele leegstaande woningen in deze wijk trekken junks, zwervers en illegale vreemdelingen aan, die voor nog meer overlast op straat en in de buurt zorgen. Junks, zwervers en illegalen zijn bevolkingscategorieën die weinig of geen formele inkomstenbronnen hebben en daarom vaak zijn aangewezen op informele inkomsten (zwart werken, drugshandel, prostitutie) of kleine criminaliteit. Ook in de Amsterdamse buurt Overtoomse Veld en aanpalende buurten klagen veel bewoners over overlast door jongeren op straat. In een enquête uit 2003 waarin bewoners een oordeel over de buurt werd gevraagd, vond ruim een kwart van de respondenten uit het stadsdeel Slotervaart dat overlast door jongeren 'veel' voorkomt in de buurt. In de buurt Overtoomse Veld was zelfs bijna de helft van de respondenten (44\%) deze mening toegedaan.

In beide steden wordt door lokale bestuurders veel beleid ontwikkeld om dergelijke problemen op het gebied van overlast en leefbaarheid te verminderen. In Amsterdam is men met name actief om de situatie te verbeteren rond problematische jeugdgroepen, die door veel bewoners als bedreigend worden ervaren. Dat dit niet altijd succes heeft blijkt uit de recente problemen in de Amsterdamse Diamantbuurt waarin een geïntimideerd echtpaar door toedoen van Marokkaanse jongeren de buurt heeft moeten verlaten (de Volkskrant 2004, 21 oktober). In Rotterdam probeert men overlast rond drugshandel, prostitutie, kleine crimi- 
naliteit en illegale bewoning aan te pakken. Uit de interviews die we in beide steden hebben gehouden, blijkt echter dat het in de Rotterdamse deelgemeente Charlois moeilijker is de leefbaarheidsproblemen te beteugelen dan in het Amsterdamse stadsdeel Slotervaart. Dat komt vooral omdat de context waarin het beleid wordt gevoerd in beide steden zo anders is. Amsterdam is in diverse opzichten een heel andere stad dan Rotterdam. Amsterdam is een aantrekkelijke stad waar ook de hooggeschoolde elite graag wil wonen. Dit veroorzaakt een permanente spanning op de Amsterdamse woningmarkt: de vraag naar woningen is groter dan het aanbod. Dit geldt niet alleen voor de (in sommige delen vrij exclusieve) binnenstad, maar inmiddels ook voor de wijken rond het stadscentrum en zelfs voor de naoorlogse wijken in de stedelijke periferie.

In Rotterdam is dit heel anders. In de deelgemeente Charlois staat een op de tien woningen leeg, in de buurt Tarwewijk zelfs één op de zes woningen. In Amsterdam blijft de leegstand beperkt tot enkele procenten. In beide steden wordt onderkend dat leegstand een groot probleem is. Leegstaande woningen bieden ruimte aan zaken die men liever niet in de buurt heeft, en als men deze woningen vervolgens ontruimt en eventueel dichtspijkert, versterken ze het gevoel bij bewoners dat het niet goed gaat met de buurt. In Amsterdam heeft men daarom een expliciet beleid om leegstand te voorkomen en ervoor te zorgen dat leegstaande woningen zo snel mogelijk opnieuw in gebruik genomen worden. In Amsterdam lukt het redelijk om leegstand te voorkomen, in 2003 bleef de leegstand in het stadsdeel Slotervaart beperkt tot minder dan twee procent. In Rotterdam lukt dit niet omdat er weinig of geen vraag naar dergelijke woningen is. Een specifiek probleem van de Tarwewijk is daarbij het grote aantal particuliere huurwoningen.

In de Tarwewijk bestaat 43 procent van de woningvoorraad uit particuliere huurwoningen, tweemaal zoveel als gemiddeld in Rotterdam. Een bijkomend probleem hiervan is dat particuliere woningbezitters ('huisjesmelkers') in de Tarwewijk en omringende buurten hun huizen onder andere aan illegalen verhuren. Dit is om diverse redenen problematisch: er wonen vaak veel illegalen op één adres en daarbij zijn ze deels aangewezen op informele of zelfs criminele inkomensbronnen - wat weer veel overlast in de buurt veroorzaakt (vgl. Leerkes et al. 2004). Toen het bestuur van de deelgemeente in 2003 de noodklok over Charlois luidde, ging het met name om onrechtmatige bewoning en vestiging van drugsgebruikers, dealers, andere kleine criminelen, illegale vreemdelingen - met andere woorden, voor iedereen die geen toegang heeft tot de reguliere arbeidsmarkt en is aangewezen op wat wel het 'souterrain van de stedelijke woningmarkt' wordt genoemd. Ook dit probleem van illegale bewoning in wijken als in de deelgemeente Charlois is ten dele verbonden met de leegstand in de stad. Ook Amsterdam kent veel buurten met veel particuliere huurwoningen, met name in de oude binnenstad en andere negentiende eeuwse wijken. Aangezien deze wijken zo aantrekkelijk zijn, ook voor hoge inkomensgroepen, zullen Amsterdamse particuliere verhuurders hun woningen niet zo snel aan bijvoorbeeld illegalen en drugsgebruikers verhuren. Ze kunnen hun woningen gemakkelijk en met minder risico kwijt aan goedverdienende yuppies. 


\section{Woningvoorraad en stedelijke herstructurering}

Een algemeen kenmerk van stedelijke achterstandsgebieden als Charlois in Rotterdam en Slotervaart in Amsterdam is de eenzijdig samengestelde bevolking: veel laaggeschoolden, uitkeringsgerechtigden, lage inkomensgroepen en minderheden. Al deze (deels overlappende) kansarme groepen worden aangetrokken door de eenzijdig samengestelde woningvoorraad in de beide steden. Rond 55 procent van alle woningen in zowel Amsterdam als Rotterdam kan tot de sociale woningbouw gerekend worden. Eveneens ruim de helft van alle woningen in beide steden behoorde tot de categorie 'goedkope huur- of koopwoningen'. Het aandeel 'dure huur- of koopwoningen' schommelde tussen 16 en 19 procent (in resp. Rotterdam en Amsterdam; alle cijfers over 2003). Bij onze onderzoeksbuurten ligt het aandeel sociale woningbouw in Overtoomse Veld nog wat hoger dan stedelijk gemiddeld (62\% van alle woningen). In Tarwewijk is het aandeel van de sociale woningbouw beduidend geringer, omdat er - zoals gezegd - zoveel particuliere huurwoningen zijn.

Conform de landelijke beleidsvisie probeert men in zowel Rotterdam als Amsterdam de eenzijdige bevolkingssamenstelling van gebieden als Charlois en Slotervaart te doorbreken door grootschalige ingrepen in de bestaande woningvoorraad. Dit proces van 'stedelijke herstructurering' of 'stedelijke vernieuwing' bestaat overigens niet alleen uit fysieke ingrepen in de woningvoorraad, maar ook uit aanvullende sociale maatregelen om problemen in de buurt te verminderen. Zowel in Charlois als Slotervaart zijn grootscheepse ingrepen in de woningvoorraad gepland. In de Westelijke Tuinsteden in Amsterdam (waartoe ook het stadsdeel Slotervaart behoort) is men voornemens om bijna een derde van de huidige sociale woningvoorraad te slopen en voor een belangrijk deel te vervangen door duurdere woningen. Uiteindelijk doel is om de sociale woningbouw te reduceren van 41 duizend woningen nu (in de hele Westelijke Tuinsteden) tot 29 duizend in 2015. In de Tarwewijk is men van plan om het aantal koopwoningen tussen nu en 2010 te verdubbelen (van 23 tot $50 \%$ van de woningvoorraad). Verder streeft men hier naar meer grotere woningen en meer eengezinswoningen.

Er kunnen verscheidene kanttekeningen geplaatst worden bij deze operatie van stedelijke vernieuwing. In de eerste plaats is het de vraag wat de sloop van goedkope huurwoningen in wijken als Charlois of Slotervaart betekent voor de huidige bewoners. In de beleidsfilosofie van stedelijke vernieuwing zijn de duurdere woningen deels bedoeld voor huidige bewoners die binnen de wijk een betere, en dus duurdere woning willen betrekken. Maar wat gebeurt er met bewoners die de duurdere woningen in de wijk niet kunnen of willen betalen? Recente studies wijzen uit dat de meeste bewoners zullen moeten vertrekken, tenzij er mogelijkheden zijn geschapen om binnen de wijk geherhuisvest te worden. Gedwongen vertrek is niet problematisch voor die groepen die toch al wilden verhuizen, maar dat is een minderheid (zie Kleinhans en Kruythoff 2002; Kleinhans 2003). In de tweede plaats kan men constateren dat een zo omvangrijke sloop- en nieuwbouwoperatie zoals voorgenomen in Charlois en Overtoomse Veld vele jaren gaat duren. Op korte termijn (dat wil zeggen, de komende 
3 of 4 jaar) zal de stedelijke vernieuwing weinig of geen effect hebben op de bevolkingssamenstelling. In de derde plaats heeft het proces van stedelijke herstructurering negatieve gevolgen voor de leefbaarheid in de buurt. Zo is er in Overtoomse Veld al grote vertraging opgetreden in het proces van stedelijke herstructurering. Dit veroorzaakt grote onzekerheid en spanningen bij bewoners die niet kunnen inschatten welke gevolgen de steeds veranderende plannen voor hen persoonlijk hebben. In de Rotterdamse Tarwewijk kan nu al worden waargenomen dat veel huiseigenaren vanwege de geplande herstructurering niet meer van plan zijn nog onderhoud aan hun woningen te verrichten, hetgeen een versneld verval van de woningen oplevert. In de vierde plaats kunnen we constateren dat juist het grote aantal particuliere eigenaren en verhuurders in de Tarwewijk wel eens een complicerende factor bij de herstructurering kan zijn. In ieder geval zal dit tot aanzienlijke vertraging van de plannen leiden (vanwege tijdrovende procedures zoals onteigening).

\section{Werkloosheid en uitkeringsafhankelijkheid}

Een laatste punt in de vergelijking tussen beide steden en beide onderzoeksbuurten betreft de aard en omvang van werkloosheid en uitkeringsafhankelijkheid. In recente beleidsstukken over de problemen in de stad heeft het Rotterdamse gemeentebestuur sterk het accent gelegd op de concentratie van 'kansarme groepen' in de stad als geheel en in achterstandswijken zoals Tarwewijk in het bijzonder. Volgens het Rotterdamse gemeentebestuur gaat het om "een bevolkingsgroep die in sociaal-economisch opzicht minder positieve vooruitzichten heeft. Uit onderzoek blijkt dat de kwalificatie vaak samenhangt met een onevenredig groot beroep op zorgvoorzieningen, een laag opleidingsniveau en inkomen en het veroorzaken van overlast" (Gemeente Rotterdam, 2004a). Tegen deze achtergrond is het interessant om naar de situatie van werkloosheid en uitkeringsafhankelijkheid in de beide onderzoeksbuurten te kijken.

Wanneer we Charlois in Rotterdam vergelijken met Slotervaart in Amsterdam, dan zien we verschillen. In Charlois ligt het aandeel werkenden (als percentage van de potentiële beroepsbevolking) beduidend lager en het aandeel werkzoekenden in Charlois aanzienlijk hoger dan in Slotervaart. Een van de redenen hiervoor is dat het stadsdeel Slotervaart in sociaal opzicht vrij divers is en zowel betere als minder goede buurten kent. Het percentage werkzoekenden in Slotervaart ligt ook beduidend lager dan gemiddeld in Amsterdam. Hetzelfde geldt als we het aandeel bijstandsontvangers in beide stadsdelen vergelijken. In Charlois had in 2003 bijna 15 procent van de totale bevolking in de werkzame leeftijd een bijstandsuitkering, in Slotervaart nog geen 6 procent. De verschillen tussen de beide onderzoeksbuurten, Tarwewijk en Overtoomse Veld, zijn weer wat minder groot. Het aandeel bijstandsontvangers lag in de Tarwewijk precies tweemaal zo hoog als in Overtoomse Veld (18 versus 9\%).

De bovenstaande schets maakt duidelijk dat de problematische gevolgen van de geschetste macrostructurele ontwikkelingen sterk zichtbaar worden in de onderzochte gebieden. Daar is sprake van een permanente instroom van (kansarme) 
migranten, daar liggen de werkloosheids- en bijstandscijfers hoger, daar ondervindt men de gevolgen van de stedelijke herstructureringsoperaties en daar spelen permanent problemen van leefbaarheid en (in mindere mate) criminaliteit. Het zijn vooral de alledaagse problemen van leefbaarheid en veiligheid, in samenhang met de permanente instroom van nieuwkomers, die veel onvrede genereren en die de sociale samenhang in wijken bedreigen. In de volgende paragraaf geven we een beschrijving van de manieren waarop gepoogd wordt om deze problemen het hoofd te bieden.

\section{SOCIALE HEROVERING IN AMSTERDAM EN ROTTERDAM}

Wie de stedelijke ontwikkelingen in Amsterdam en Rotterdam in ogenschouw neemt en de problemen overziet, wordt, ondanks de verschillen tussen de steden en de onderzochte locaties, getroffen door de overeenkomsten in aanpak. Deze stedelijke aanpakken zoals die beschreven zijn in de hoofdstukken 5 en 6 zouden wij willen duiden met het begrip sociale herovering. Sociale herovering staat voor sociale en fysieke interventies gericht op (1) vergroten van de leefbaarheid en veiligheid in de publieke ruimte; (2) het realiseren van een meer evenwichtige samenlevingsopbouw ${ }^{1}$, en (3) het formuleren van gemeenschappelijke competenties en gedragsregels om het alledaagse verkeer tussen bewoners te bevorderen. Deze beleidsstrategie is gericht op die buurten waarin de leefbaarheid en sociale samenhang een kritische grens hebben overschreden en waarin het gangbare beleid te weinig successen heeft geboekt. In de bepaling van deze kritische grens spelen zowel objectiveerbare zaken een rol (veiligheidscijfers, uitkeringsdichtheid, overlast, verdwijnen van winkels, et cetera), alsmede subjectieve zaken die samenhangen met spraakmakende incidenten en met het vermogen van bewoners en bestuurders om wijkspecifieke problemen hoog op de politieke agenda te krijgen.

In het proces van sociale herovering is een bescheiden plaats toebedeeld aan 'klassieke' hulpverleners uit de sfeer van het sociaal beleid, zoals sociale dienstfunctionarissen en welzijn- en maatschappelijk werkers. De centrale actoren zijn nu veiligheids- en justitiefunctionarissen, buurt- en wijkfunctionarissen, interventieteams, maar ook woningbouwcorporaties en andere private partijen, zoals projectontwikkelaars (zie de hoofdstukken 5 en 6). Deze verandering is het gevolg van het sterke beleidsaccent dat nu gelegd wordt op veiligheid en verandering van de woningvoorraad. Deze 'wisseling van de wacht' houdt tegelijkertijd een kritiek in op traditionele beroepsgroepen uit de sociale sector. Hun werksoorten zijn onvoldoende effectief gebleken in het realiseren van een leefbare omgeving.

\section{Herontdekking van stedelijke problemen}

De beleidsstrategie van sociale herovering heeft in Amsterdam en Rotterdam drie gemeenschappelijke kenmerken. Ten eerste is er sprake van een herontdekking van stedelijke problemen. Er is een omslag waarneembaar waarbij bewoners, deelgemeenten, gemeentelijke diensten, politie en justitie, woningbouwcorporaties 
et cetera, met inzet van nieuwe middelen proberen te achterhalen welke gewenste en ongewenste praktijken plaatsvinden in buurten en achter de façades van bedrijven en de voordeuren van pensions en woningen in de wijk. Er wordt geprobeerd om de sociale structuur van de wijk weer transparant te maken. Daarmee kunnen diverse illegale praktijken die overlast en onveiligheid veroorzaken effectief worden bestreden. Ook wordt geprobeerd om een scherper zicht te krijgen op problematische groepen (jeugddelinquenten, schoolverlaters) waardoor een meer gericht beleid mogelijk is.

\section{Indringende aanpak}

De herontdekking van de stad gaat, ten tweede, gepaard met een indringende aanpak. Die aanpak is (1) repressief en (2) normerend van aard en (3) schuwt interventies in de private levenssfeer van mensen niet. Deze aspecten worden vooral zichtbaar in het voorgestane veiligheidsbeleid en integratiebeleid. Een voorbeeld van een repressieve aanpak zijn de integrale controle acties (waaronder preventief fouilleren) in Rotterdam in het kader van de hotspot-benadering die ertoe moeten leiden dat de sociale en veiligheidsproblemen op diverse plekken in Charlois worden aangepakt. Daarbij gaat het om het bestrijden van zaken als illegale kamerverhuur, dealpanden, hennepkwekerijen en illegale seksinrichtingen. Een Amsterdams voorbeeld is de aanpak van een harde kern van criminele jongeren. Het belangrijkste middel om de harde kern te verminderen is het langdurig 'van de straat halen' of 'wegzetten' van criminele jongeren in justitiële inrichtingen of in resocialisatiecentra. De gemeente Amsterdam bijvoorbeeld heeft een aantal plaatsen in resocialisatiecentra gehuurd. Daar kunnen criminele jongeren voor een jaar naar toe worden gestuurd.

\section{Integrale, samenhangende aanpak}

Een derde kenmerk van de Amsterdamse en Rotterdamse benadering is het vorm geven van een integrale, samenhangende aanpak. In het verleden impliceerde een integrale aanpak vaak dat er een extra vergaderniveau bijkwam, nu worden diverse projecten ontwikkeld waarbij daadwerkelijk wordt samengewerkt. Een voorbeeld daarvan zijn de interdisciplinair samengestelde interventieteams die zijn ontwikkeld om het souterrain van de woningmarkt aan te pakken. Een ander voorbeeld zijn de samenwerkingsverbanden die zijn opgezet met woningbouwcorporaties en projectontwikkelaars om grootscheepse herstructureringsprojecten in de volkshuisvesting te realiseren. Deze laatste samenwerkingsverbanden maken duidelijk dat in achterstandswijken relevante publiek-private samenwerkingsconstructies mogelijk zijn.

\section{Hogere en lagere schaalniveaus}

Naast deze drie gemeenschappelijke kenmerken van de Rotterdamse en Amsterdamse aanpak verschillen Amsterdam en Rotterdam van elkaar in de mate waarin zij zich richten op hogere en lagere schaalniveaus om de stedelijke problematiek het hoofd te bieden. Rotterdam wil in samenspraak met het rijk een selectief vestigingsbeleid ontwikkelen dat het mogelijk moet maken om (inkomens)eisen te stellen aan woningzoekenden van buiten de regio Rotterdam. Eind augustus 
2004 heeft het college van Burgemeesters en Wethouders een concreet voorstel gedaan aan de gemeenteraad om per 1 oktober 2004 als experiment in enkele delen van Rotterdam (in delen van Charlois, Feijenoord en Delfshaven) de zogenaamde huisvestingsvergunning in te voeren. In de experimentgebieden worden nieuwe huurders dan verplicht een huisvestingsvergunning aan te vragen, waarbij de aanvraag vervolgens getoetst wordt op inkomen en op overbewoning. Deze aanpak waarbij een gemeente een 'lokaal immigratiebeleid' wenst te voeren is een opvallend kenmerk van de nieuwe Rotterdams aanpak. Andere voorbeelden hebben betrekking op het tot stand brengen van een regionaal huisvestingsbeleid om zodoende tot een meer evenwichtige spreiding te komen van kansarme groepen (waaronder veel migranten).

Dergelijke opvattingen hoort men niet in Amsterdam. De Amsterdamse stadsen stadsdeelbestuurders zijn er redelijk van overtuigd dat ze met alle nieuwe aanpakken goed op weg zijn om verloedering in de achterstandswijken tegen te gaan. In Amsterdam wordt vooral gewezen op de betekenis van een decentrale aanpak op stadsdeelniveau. Een decentraal bestuur, zo is de overtuiging, heeft beter zicht op de specifieke aard van lokale problemen. Van belang zou zijn dat in Amsterdam allerlei diensten en organisaties op stadsdeelniveau georganiseerd zijn, waardoor er een bestuurlijke capaciteit aanwezig is om problemen op te lossen. In Rotterdam onderkent men ook de relevantie van een decentrale aanpak, maar bestaat er meer twijfel over de betekenis van deelgemeenten indien zij onvoldoende greep hebben op de gemeentelijke diensten waar ze gebruik van moeten maken. Ook wordt in Rotterdam - en dit geldt vanzelfsprekend ook voor Amsterdam - gewezen op de verschillen tussen deelgemeenten in politiekbestuurlijke kwaliteit. De deelgemeente Charlois, bijvoorbeeld, heeft een aantal daadkrachtige bestuurders, maar dat geldt niet voor alle deelgemeenten. Daarnaast is men in Rotterdam van mening dat deelgemeenten soms een vorm en een schaal hebben die ongunstig zijn voor de herkenbaarheid. Het zou meer voor de hand liggen om de uitvoering te organiseren via meer herkenbare deelgebieden op het niveau van de buurt en de straat (Vuijsje 2004). Dat is in feite wat bij veel nieuwe Rotterdamse projecten in het kader van 'sociale herovering' ook gebeurt. Datzelfde geldt overigens ook voor Amsterdam.

Voor beide gemeenten geldt dat ze zich bewust zijn van mogelijke spill overeffecten, dat wil zeggen dat ingrepen in een bepaald gebied gevolgen kunnen hebben voor andere straten, buurten, wijken en randgemeenten. Dit bewustzijn leidt ertoe dat samenwerking plaatsvindt tussen stadsdelen (Amsterdam) en deelgemeenten (Rotterdam), bijvoorbeeld op het gebied van veiligheidsbeleid. In geval van Rotterdam leidt het ook tot een sterk pleidooi tot samenwerking met randgemeenten en het rijk.

\subsection{INDELING VAN DEZE STUDIE}

In hoofdstuk 1 wordt het thema ingeleid en de centrale bevindingen van het onderzoek uiteengezet. In hoofdstuk 2 wordt ingegaan op de macrostructurele 
ontwikkelingen die van grote invloed zijn op de stedelijke ontwikkeling in Amsterdam en Rotterdam. Daarbij wordt aandacht besteed aan vier belangrijke maatschappelijke processen: voortschrijdende migratie, economische structuurveranderingen, veranderingen in de stedelijke woningvoorraad en ontwikkelingen in criminaliteit en veiligheid. In hoofdstuk 3 en 4 zal vervolgens ingezoomd worden op twee stedelijke gebieden, respectievelijk de wijk Overtoomse Veld in stadsdeel Slotervaart in Amsterdam en de Tarwewijk in deelgemeente Charlois in Rotterdam. Daarbij laten we onder andere zien wat de gevolgen zijn van de vier beschreven grootstedelijke processen voor de twee onderzochte gebieden. In hoofdstuk 5 en 6 gaan we in op de specifieke manieren waarop in de twee onderzochte gebieden geprobeerd wordt om de sociale en fysieke structuur van de wijk te verbeteren, alsmede de kwaliteit en leefbaarheid van de openbare ruimte. In hoofdstuk 5 wordt de aanpak in de Tarwewijk beschreven. Er wordt ingegaan op de recente ontwikkelingen in het denken over Rotterdam en op de kenmerken van de Rotterdamse aanpak zoals die zichtbaar wordt in de Tarwewijk. In hoofdstuk 6 volgt eenzelfde beschrijving als in hoofdstuk 5, maar dan voor de wijk Overtoomse Veld. We eindigen in hoofdstuk 7 met een korte samenvatting van de belangrijkste kenmerken van de aanpak in Amsterdam en Rotterdam.

\subsection{METHODISCHE VERANTWOORDING}

De empirische basis van het rapport wordt gevormd door eigen onderzoek dat eerder in Rotterdam is verricht, secundaire bronnenanalyse, statistische analyse en semi-gestructureerde interviews (in totaal 21 interviews).

Om een beeld te krijgen van de macro-ontwikkelingen in Amsterdam en Rotterdam en het aldaar gevoerde beleid zijn ten eerste relevante beleidsdocumenten en rapporten bestudeerd en statistische gegevens geanalyseerd en bewerkt. Er zijn enkele personen geïnterviewd om inzicht te krijgen in de achtergronden van de stedelijke contexten van Amsterdam en Rotterdam. Om vervolgens tot een keuze te komen van de wijken voor nader onderzoek, hebben we verschillende kerncijfers van wijken vergeleken en beleidsnota's en verschillende mediabronnen geraadpleegd. De criteria voor de keuze van de wijken waren dat het gesegregeerde wijken moesten zijn (wijken met een grote mate van concentratie van allochtonen) en die verder ook representatief moesten zijn voor de twee grote steden qua aard, omvang en hardheid van de sociale vraagstukken die er spelen. Een ander criterium was dat er in de wijken nieuwe initiatieven ontwikkeld zijn om de situatie te verbeteren.

Als eerste kennismaking met de geselecteerde onderzoeksvelden in Charlois en Slotervaart zijn secundaire bronnen bestudeerd zoals beleidsnota's, onderzoeksrapporten, informatiefolders en gemeentegidsen. Om de problemen en aanpakken in de geselecteerde buurten Overtoomse veld in Amsterdam-West en de Tarwewijk in de Rotterdamse deelgemeente Charlois in kaart te brengen heeft het onderzoeksteam in de periode februari tot en met juni 2004 vervolgens verschillende semi-gestructureerde interviews met sleutelpersonen gehouden en 
zijn er enkele bijeenkomsten bijgewoond. Voor een lijst van de respondenten zie de bijlage. Het betrof bestuurders van de deelgemeente/ het stadsdeel, directeuren van instellingen, et cetera. Deze respondenten zijn geselecteerd op basis van gesprekken met mensen die goed ingevoerd zijn in de thematiek en de onderzoeksvelden. ${ }^{2}$ Naast de interviews zijn ook schriftelijke bronnen als informatiefolders, jaarverslagen, beleidsplannen, begrotingen, bestuursnotulen en internetsites geraadpleegd om aan informatie over initiatieven in de wijken te komen. 


\section{NOTEN}

$1 \quad$ Deze doelstelling wordt overigens zelden geëxpliciteerd. Achter deze doelstellingen gaat veelal de wens schuil om enerzijds middengroepen te behouden en aan te trekken, en anderzijds om sociale problemen te verminderen door middel van het vertrek van specifieke, lage inkomensgroepen. Wij danken allen die hebben meegewerkt aan de totstandkoming van dit rapport. Onze dank gaat in het bijzonder uit naar de respondenten die ons openhartig te woord hebben gestaan. Ook gaat onze dank uit naar enkele sleutelpersonen die een kritische blik hebben geworpen op de conceptversie van het rapport. Dat geldt in het bijzonder voor R. Kleinhans van het Отв. Vanuit de opdrachtgever - de Wetenschappelijke Raad voor het Regeringsbeleid - is er commentaar gekregen van prof. dr. P. Winsemius, dr. C.A. Hazeu en mw. ir. M. Jager-Vreugdenhil (allen verbonden aan het Buurtproject van de WRR). Het onderzoek is uitgevoerd door prof. dr. G. Engbersen, prof. dr. E. Snel en mw. A. Weltevrede, die werkzaam zijn op de Erasmus Universiteit Rotterdam en/of de Universiteit Twente. Zij werden geassisteerd door Ruud Verbeek (student EUR). Wij danken hem voor zijn bijdragen aan dit rapport. 
2 MACROSTRUCTURELE ONTWIKKELINGEN IN AMSTERDAM EN ROTTERDAM

\subsection{VISIES OP STEDELIJKE ONTWIKKELING}

Een van de meest invloedrijke theorieën over stedelijke ontwikkelingen is het werk van Saskia Sassen over global cities. De centrale stelling van Sassen (1991) is dat in het tijdperk van globalisering een beperkt aantal grote steden uit de westerse wereld in toenemende mate fungeert als de sturingscentra van de wereldeconomie. Global cities als New York, Tokyo en Londen zijn belangrijke productieplaatsen voor een groot aantal gespecialiseerde - in het bijzonder financiële - diensten die nodig zijn voor de management- en controlefuncties die zij vervullen. Een van de kenmerken van deze global cities is volgens Sassen tevens de toenemende polarisatie op de arbeidsmarkt. Volgens Sassen genereert de specifieke kennis- en diensteneconomie in deze steden niet alleen gespecialiseerde banen op hoog niveau, maar ook veel laaggekwalificeerd en laagbetaald werk, met name in de sfeer van dienstverlening. Zowel hoogwaardige bedrijven als hun doorgaans goedbetaalde werknemers genereren een vraag naar laagwaardige dienstenarbeid. Bedrijven hebben behoefte aan schoonmakers, bewakers en horecavoorzieningen, hun werknemers maken gebruik van allerlei diensten (horeca, uitgaan, cultuur, persoonlijke dienstverlening zoals kinderoppas, et cetera). Juist deze laaggekwalificeerde dienstenarbeid in de global cities zou, aldus Sassen, nieuwe kansen bieden voor veelal laaggeschoolde migranten die naar de global cities trekken.

Amsterdam wordt wel genoemd als een opkomende global city, onder meer door Sassen zelf. We zien in Amsterdam dan ook zekere polarisatietendensen op de arbeidsmarkt, met name bij de postindustriële beroepen. Amsterdam is enerzijds een plek waar de stedelijke elite graag wil werken én wonen, maar biedt anderzijds ook in toenemende mate laaggeschoolde werkgelegenheid voor de vele migranten en minderheden in de stad (vgl. Snel et al. 2001; Burgers \& Musterd 2002). Gesproken wordt wel van 'tweepoligheid' als typisch kenmerk van de stedelijke ontwikkeling in Amsterdam. Zowel op de arbeidsmarkt als op de woningmarkt is sprake van groei aan de bovenkant én aan de onderkant (Musterd et al. 2001).

In Rotterdam gaat de ontwikkeling vooralsnog een andere richting uit. Typerend voor Rotterdam is dat de hooggeschoolde elite nog wel in de stad werkt, maar er niet woont. Zowel de hogere klassen als de middengroepen hebben de neiging de stad te verlaten. Wat achterblijft zijn degenen met weinig kansen op de hedendaagse arbeidsmarkt, onder wie veel nieuwkomers en minderheden. In Rotterdam zien we niet zozeer een polarisatie, maar veeleer een tendens van degradatie op de arbeidsmarkt. Terwijl een toenemend aandeel van de werkende bevolking van Rotterdam in laag- of ongeschoolde hand- of dienstenberoepen werkt, neemt het aandeel hooggeschoolde professionals in de Rotterdamse bevolking ziender- 
ogen af (Snel et al. 2001). Dit verschil in ontwikkeling tussen Amsterdam en Rotterdam is misschien niet specifiek voor beide steden. In de recente sociaalwetenschappelijke discussie over stedelijke ontwikkeling wordt vaker gewezen op de groeiende verschillen tussen steden in hetzelfde land. Terwijl de eerste stad van een land zich ontwikkelt, treedt in de tweede stad van het land een zekere stagnatie op met als gevolg dat de kloof tussen steden steeds groter wordt (Sassen et al. 2002). Een belangrijke conclusie uit dit hoofdstuk over stedelijke ontwikkelingen in Amsterdam en Rotterdam is dat dit ook voor deze beide steden opgaat. De ontwikkelingen op zowel de arbeidsmarkt als de woningmarkt in Amsterdam zijn anders dan in Rotterdam.

\subsection{HET ONTSTAAN VAN MULTICULTURELE STEDEN EN BUURTEN}

Nederland wordt ten onrechte vaak een multiculturele samenleving genoemd. Men kan grote delen van het land doorkruisen zonder al te veel migranten en

Figuur 2.1 Bevolkingsontwikkeling in Amsterdam (1980-2020) en Rotterdam (1986-2017)
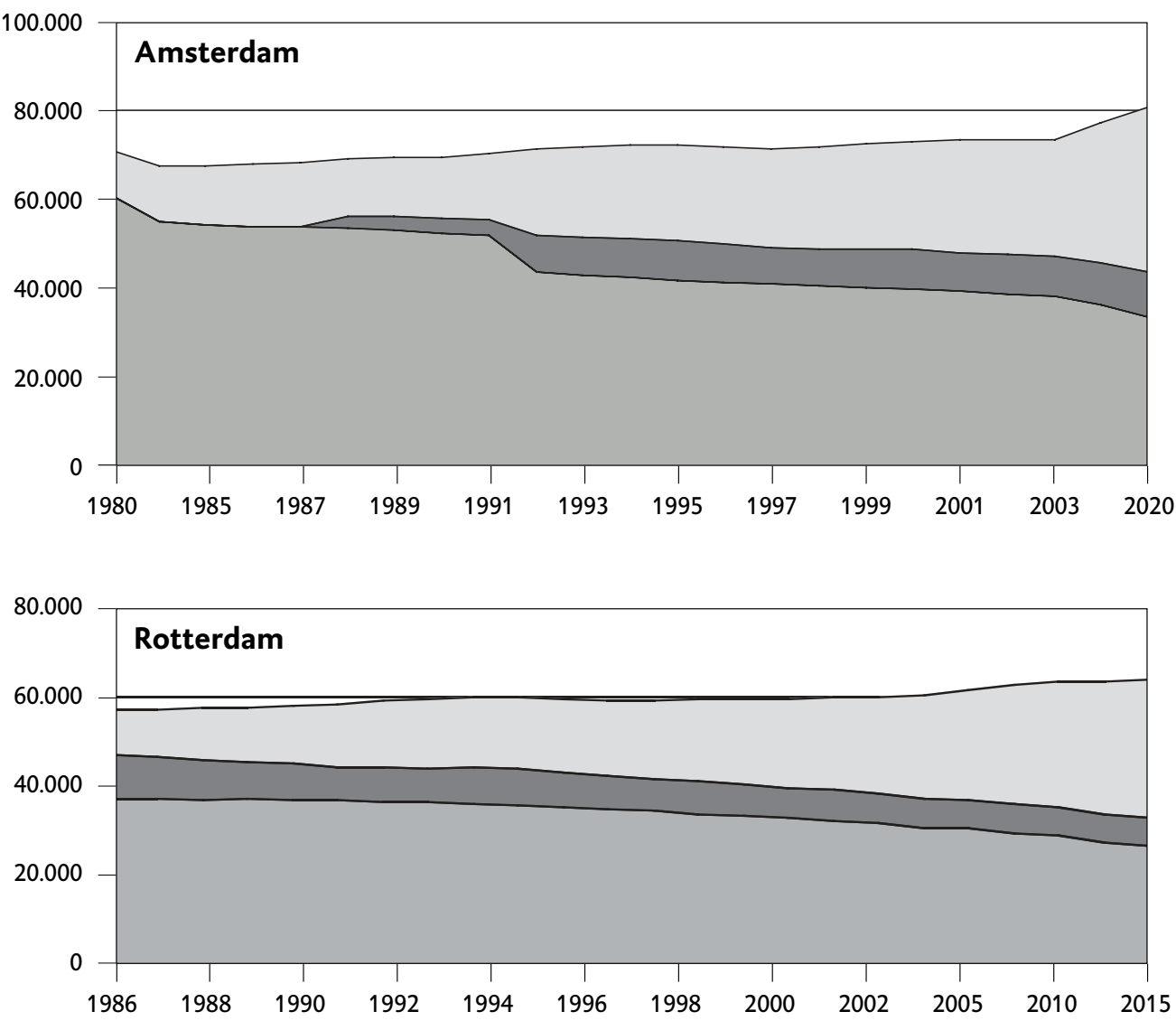
leden van etnische minderheidsgroepen tegen te komen. Dat komt omdat een groot deel van de migranten en minderheden sterk geconcentreerd woont in de grote steden van ons land. Autochtone Nederlanders hebben daarentegen sinds decennia de neiging om uit de grote steden weg te trekken. Het resultaat van dit geheel van selectieve bevolkingsontwikkelingen is dat de grote steden in ons land - Amsterdam en Rotterdam voorop - zich in rap tempo tot multiculturele steden hebben ontwikkeld. In beide steden ontstaat binnen afzienbare tijd de situatie dat de zogenaamde etnische minderheden (dat wil zeggen eerste en tweede generatie migranten afkomstig uit niet-westerse landen) de meerderheid van de bevolking zullen vormen. In Amsterdam staat dit volgens de huidige bevolkingsprognoses ergens rond 2030 te gebeuren, in Rotterdam al eerder (rond 2017). Autochtone Nederlanders vormen dan allang niet meer de meerderheid van de bevolking (figuur 2.1).

Rotterdam telde in 2003 een krappe 600 duizend inwoners en was daarmee de tweede stad van het land. In beide steden was het bevolkingsaantal de afgelopen decennia min of meer stabiel, maar de komende decennia wordt nieuwe bevolkingsgroei verwacht. In Amsterdam zal de bevolking tussen 2003 en 2020 volgens de huidige demografische prognoses groeien van 736 duizend tot ruim 8 oo duizend personen, in Rotterdam van 599 duizend tot 635 duizend (in 2017). ${ }^{1}$ Deze nieuwe bevolkingsgroei in beide steden is vooral te danken aan het snelgroeiende aantal niet-westerse allochtonen (eerste en tweede generatie migranten afkomstig uit niet-westerse landen). Het aantal autochtone bewoners van Amsterdam en Rotterdam zal ook de komende jaren, net als de afgelopen decennia, verder afnemen.

Uit de beide figuren komt duidelijk naar voren dat de verkleuring van de stad niet alleen het gevolg is van de komst van niet-westerse allochtone bewoners, maar ook - en misschien vooral - door het vertrek van autochtonen uit de stad.

Er is met andere woorden op grote schaal sprake van vervanging van de stedelijke bevolking. In 1980 telde Amsterdam nog 600 duizend autochtone bewoners, in 2003 was hun aantal met meer dan een derde verminderd (380 duizend personen). In Rotterdam daalde het aantal autochtone bewoners tussen 1986 en 2003 van 371 duizend tot 318 duizend ( $53 \%$ van de bevolking). De verwachting is dat het aantal autochtonen in beide steden tussen 2003 en pakweg 2020 met nog eens zo'n 45 tot 50 duizend zal verminderen. In Amsterdam bestond de bevolking in 1980 nog voor 85 procent uit autochtonen, in 2003 was dat nog krap de helft (52\%) en in 2020 zal naar verwachting het aandeel autochtonen onder de Amsterdamse bevolking gedaald zijn tot 42 procent. In Rotterdam bestond de bevolking in 1986 nog voor 65 procent uit autochtonen, in 2003 was dat 53 procent en in 2017 naar verwachting nog slechts 44 procent. Men kan concluderen dat autochtonen in versnelde mate de stad verlaten - ze stemmen met de voeten!

Tegelijkertijd neemt het aantal minderheden of niet-westerse allochtonen (beide termen worden hier door elkaar gebruikt) onder de Amsterdammers en Rotterdammers snel toe. In 1988 telde Amsterdam bijna 130 duizend bewoners met een 
niet-westerse allochtone herkomst (vóór die tijd werd in de gemeentelijke statistieken geen onderscheid gemaakt tussen westerse en niet-westerse allochtonen). In 2003 was het aantal niet-westerse allochtonen in Amsterdam opgelopen tot ruim 260 duizend en in 2020 zal het verder gegroeid zijn tot 370 duizend. Ook in Rotterdam groeit het aantal niet-westerse allochtonen onder de bevolking snel. Het aantal Rotterdammers met een niet-westerse allochtone achtergrond groeide van ruim 100 duizend in 1986 tot bijna 214 duizend in 2003 en zal naar verwachting in 2017 zijn opgelopen tot ruim 300 duizend. In zowel Amsterdam als Rotterdam zal dus het niet-westerse allochtonen onder de bevolking in pakweg 30 jaar (bijna) verdrievoudigd zijn. Aan het einde van deze periode zullen de zogenaamde minderheden in beide steden de meerderheid van de bevolking vormen.

De situatie dat minderheden de meerderheid van de bevolking vormen is nu echter al in tal van Amsterdamse en Rotterdamse buurten te zien (zie tabel 2.1). De twee buurten waarin we in dit onderzoek nader ingaan (de buurt Overtoomse Veld in het stadsdeel Slotervaart ${ }^{2}$ in Amsterdam en de buurt de Tarwewijk in de deelgemeente Charlois in Rotterdam) zijn voorbeelden van deze 'gekleurde buurten'. De bevolkingsontwikkeling en problematiek van beide buurten en van de stadsdelen waarin zij liggen, worden in het volgende hoofdstuk uitgebreid besproken.

Tabel 2.1 Buurten in Amsterdam en Rotterdam met verhoudingsgewijs het hoogste minderhedenaandeel ('niet-westerse allochtonen') onder de buurtbevolking (gegevens 2003)

\begin{tabular}{|c|c|c|c|}
\hline Buurten in Amsterdam & $\%$ & Buurten in Rotterdam & $\%$ \\
\hline Bijlmer-Centrum & 82,5 & Spangen & 73,9 \\
\hline De Kolenkit & 81,4 & Feijenoord & 71,8 \\
\hline Bijlmer-Oost & 73,9 & Afrikaanderwijk & 69,9 \\
\hline Overtoomse Veld & 66,2 & Bospolder & 66,3 \\
\hline Indische Buurt-West & 65,9 & Schiemond & 65,9 \\
\hline Osdorp-Midden & 64,8 & Tussendijken & 65,1 \\
\hline Indische Buurt-Oost & 61,8 & Hillesluis & 64,9 \\
\hline Transvaalbuurt & 59,7 & Nieuwe Westen & 59,4 \\
\hline Geuzenveld & 58,6 & Oude Westen & 58,4 \\
\hline Slotermeer-Noordoost & 57,5 & Bloemhof & 52,5 \\
\hline IJ-eiland en omstreken & 57,2 & Oude Noorden & 50,3 \\
\hline Landlust & 56,7 & Agniesebuurt & 50,1 \\
\hline Nieuwendam-Noord & 54,2 & Tarwewijk & 48,7 \\
\hline IJplein/Vogelbuurt & 52,9 & Nieuw-Crooswijk & 48,6 \\
\hline Van Galenbuurt & 52,8 & Oud-Crooswijk & 47,3 \\
\hline
\end{tabular}




\subsection{POSTINDUSTRIËLE STEDELIJKE ECONOMIEËN?}

Nederland heeft een in economisch opzicht zeer gunstige periode achter de rug. Met name in de tweede helft van de jaren negentig kende Nederland een forse economische groei en banengroei. De vraag is of ook de grote steden met hun kwetsbare beroepsbevolking van deze gunstige ontwikkelingen hebben geprofiteerd. Meer algemeen kan gesteld worden dat de situatie in de grote steden op het gebied van werk en inkomen vrij paradoxaal is. Aan de ene kant worden de grote steden vaak als motor van de regionale en landelijke economie gezien, aan de andere kant liggen de werkloosheid en uitkeringsafhankelijkheid hier beduidend hoger dan gemiddeld in Nederland. Dit komt doordat veel werkenden in de grote steden niet in de stad wonen ${ }^{3}$ en omgekeerd, dat veel stedelingen - met name de lager opgeleiden onder hen - niet of niet meer werken.

We kunnen concluderen dat vooral Amsterdam behoorlijk geprofiteerd heeft van de gunstige economische ontwikkeling en banengroei in Nederland in de tweede helft van de jaren negentig. Tussen 1992 en 2002 steeg het totale aantal banen in Amsterdam met 30 procent. Vooral in de zakelijke dienstverlening en de horeca groeide de werkgelegenheid in Amsterdam. In Rotterdam was de banengroei in dezelfde periode aanzienlijk minder (14\%). ${ }^{4}$ Mede als gevolg van deze economische ontwikkeling, en misschien ook van het strengere optreden van sociale diensten en andere uitkeringsinstanties, is het aantal werklozen en andere uitkeringsgerechtigden de afgelopen jaren in steden als Amsterdam en Rotterdam behoorlijk teruggelopen. In 1998 leefde nog bijna een op de vier volwassenen in de werkzame leeftijd (tussen 15 en 64 jaar) in Amsterdam en Rotterdam van een uitkering, in 2002 was het aandeel uitkeringsgerechtigden in beide steden teruggelopen tot ruim 19 procent. Hiermee was het aandeel uitkeringsontvangers in beide steden ongeveer anderhalf maal zo hoog als gemiddeld in Nederland (krap $14 \%$; figuur 2.2).

Wat betreft het aandeel uitkeringsgerechtigden is er dus weinig of geen verschil tussen Amsterdam en Rotterdam. Wel is er enig verschil als we naar het soort uitkeringen kijken. In Rotterdam zijn er verhoudingsgewijs meer bijstandsgerechtigden dan in Amsterdam en veel meer dan in de rest van Nederland. Daar staat echter tegenover dat er in Amsterdam, maar ook in heel Nederland, verhoudingsgewijs meer arbeidsongeschikten (WAO, WAZ en Wajong) zijn dan in Rotterdam.

Tot nog toe lijkt het alsof er weinig verschillen zijn in de sociaal-economische ontwikkeling. Dat is echter afhankelijk van de manier waarop men ernaar kijkt. Kijkt men naar het aandeel stedelingen dat werkloos of anderszins afhankelijk van een uitkering is, dan ziet men weinig verschil tussen beide steden. Kijkt men echter meer algemeen naar alle mensen die in Amsterdam en Rotterdam werken en de beroepen die zij uitoefenen, dan zien we echter wel belangrijke verschillen en verschillende ontwikkelingen. 
Figuur 2.2 Ontvangers van een uitkering (ABW, IOAW/IOAZ, AO en WW) in de vier grote steden en in Nederland als percentage van de totale bevolking in de werkzame leeftijd (15-64 jaar) (2002)

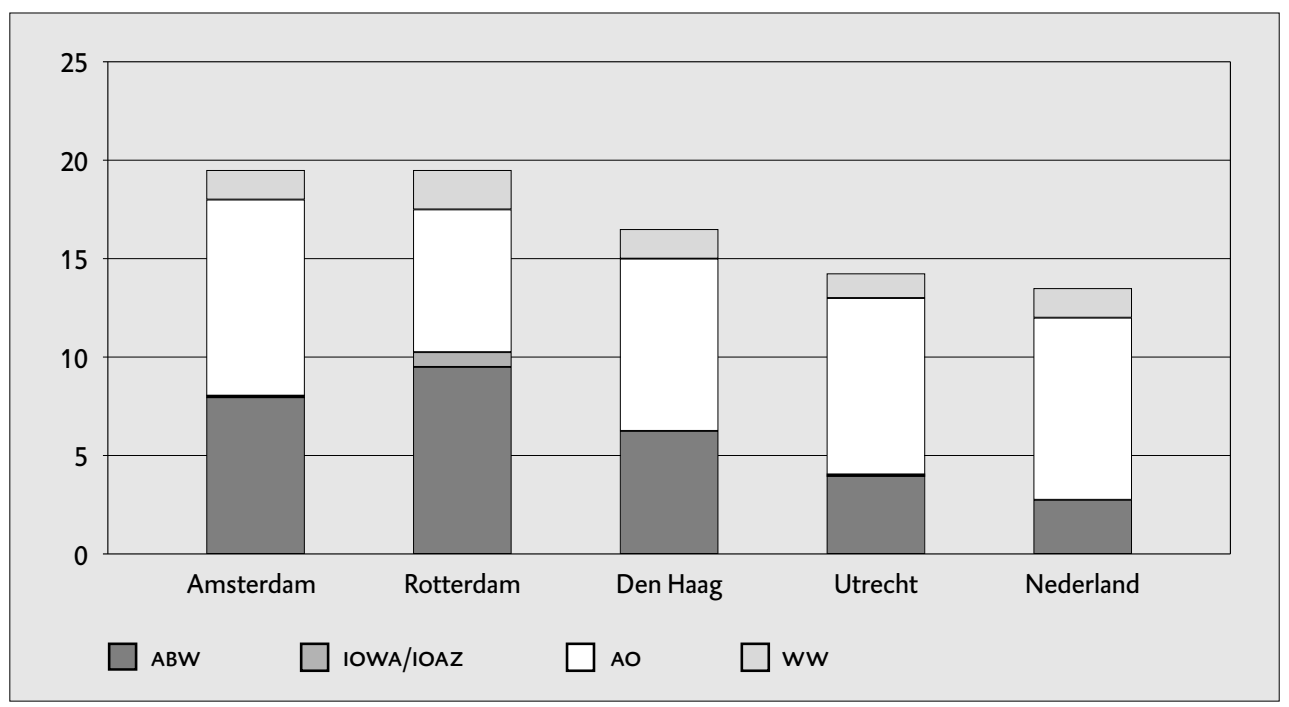

Bron: Nyfer, Atlas voor gemeenten 2003

We komen deze verschillen op het spoor als we teruggaan naar Sassens notie van global cities. Sassen onderscheidt twee kenmerkende ontwikkelingen in de beroepenstructuur van global cities: enerzijds de overgang van een traditionele, industriële beroepenstructuur naar een postindustriële beroepenstructuur en anderzijds een tendens van polarisatie van de beroepenstructuur. Met dit laatste wordt bedoeld dat er op de arbeidsmarkt van global cities sprake zou zijn van groei in zowel het aantal hooggekwalificeerde en goedbetaalde beroepen als in het aantal laaggekwalificeerde en laagbetaalde beroepen. Wat minder belangrijk wordt of misschien zelfs wel verdwijnt, is het middensegment van de stedelijke arbeidsmarkt (de these van de declining middle).

Wanneer men vanuit dit perspectief naar de ontwikkelingen op de arbeidsmarkt in Amsterdam en Rotterdam kijkt, dan ziet men inderdaad opmerkelijke verschillen (vgl. Steijn et al. 2000; Snel et al. 2001; Burgers en Musterd 2002). Allereerst wat betreft de tendens tot postindustrialisering van de beroepenstructuur van beide steden, deze is in Amsterdam verder voortgeschreden dan in Rotterdam. Wanneer men alle hoog- en laaggekwalificeerde dienstenberoepen bij elkaar optelt, dan schommelt het aandeel van de postindustriële beroepen op de totale beroepenstructuur in Nederland rond 40 procent. In zowel Amsterdam als Rotterdam ligt het aandeel postindustriële beroepen echter beduidend hoger dan landelijk gemiddeld. In Amsterdam kan zelfs meer dan de helft (bijna 52\%) van alle beroepen tot de postindustriële beroepen gerekend worden, in Rotterdam ligt het aandeel van de postindustriële beroepen aanzienlijk lager - zij het wel hoger dan landelijk gemiddeld (rond 47\%). 
Gegeven de economische geschiedenis van beide steden is dit verschil in uitkomsten te begrijpen. Rotterdam en Amsterdam hebben de afgelopen decennia zeer verschillende ontwikkelingen doorgemaakt. Rotterdam is vanouds een werkstad, waar echter de industriële werkgelegenheid door het proces van economische herstructurering sterk aan betekenis heeft ingeboet. Hét probleem van Rotterdam is dat de banen die de afgelopen decennia in de haven en industrie verloren zijn gegaan, niet of slechts in beperkte mate zijn opgevuld door nieuwe banen in de stedelijke diensteneconomie. Hoewel er de afgelopen decennia ook in Amsterdam veel banen in de haven en industrie verloren zijn gegaan, was hier tegelijk sprake van een sterke groei in de sfeer van postindustriële beroepen. Dit komt niet alleen door de sterke groei van de stedelijke kennis- en diensteneconomie in Amsterdam (denk aan Amsterdam-Zuid), maar zeker ook door de bloeiende horeca en de cultuur- en vermaakindustrie, die veel werkgelegenheid bieden.

Een ander punt betreft niet zozeer het soort (industrieel versus postindustrieel), maar het niveau van de beroepen. Volgens Sassen kennen de global cities een gepolariseerde beroepenstructuur. De nieuwe stedelijke economieën bieden volgens haar niet alleen werk aan hooggekwalificeerde werknemers, maar ook aan laaggeschoolden (bijv. horeca- en toerismebranche, de schoonmaaksector, beveiliging, persoonlijke dienstverlening, enz.). We hebben bekeken in hoeverre deze polarisatietendensen in de stedelijke beroepenstructuur zichtbaar zijn in Amsterdam en Rotterdam en kwamen tot enkele opmerkelijke bevindingen (vgl. Steijn et al. 2000; Snel et al. 2001).

In Amsterdam is inderdaad een zekere polarisatietendens in de sfeer van postindustriële beroepen zichtbaar: zowel het aantal personen met een hooggeschoold dienstenberoep als het aantal personen met een laag- of ongeschoold dienstenberoep is hier gedurende de jaren negentig gestegen. In Rotterdam zien we een heel andere ontwikkeling, die ook nog eens verschilt als men kijkt naar degenen die in de stad werken (maar er niet per definitie wonen) óf naar degenen die er wonen (maar misschien elders werken). Kijken we naar het beroep van bewoners van Rotterdam, dan zien we een forse groei van het aandeel personen dat ongeschoold werk verricht (zowel in de industriële als in de postindustriële beroepen). Kijken we naar degenen die in Rotterdam werken, maar wellicht elders wonen, dan zien we eerder een tendens van professionalisering van de beroepenstructuur: wat méér hooggeschoolde beroepen en minder ongeschoold werk (met name bij de postindustriële beroepen). Dit is in feite een tendens van degradatie op de arbeidsmarkt.

De conclusie uit de analyse is dat er grote lokale verschillen in de ontwikkeling van de grootstedelijke arbeidsmarkten kunnen zijn. Niet alleen is de tendens tot postindustrialisering van de arbeidsmarkt in Amsterdam verder voortgeschreden dan in Rotterdam, ook zijn er belangrijke verschillen in het niveau van de postindustriële beroepen. In Amsterdam lijkt er - zoals voorspeld in de these van global cities - inderdaad sprake van een zekere polarisatie van de arbeidsmarkt, zeker in de sfeer van postindustriële beroepen. Aangezien we mogen aannemen 
dat het aandeel postindustriële beroepen in de toekomst verder zal toenemen, ligt het voor de hand dat de Amsterdamse arbeidsmarkt steeds sterker in het teken van polarisatie komt te staan. In Rotterdam ligt dit anders. Het meest opmerkelijke in de werkgelegenheidsontwikkeling in Rotterdam is het grote verschil als men naar de werkenden in Rotterdam kijkt of naar de in Rotterdam woonachtige beroepsbevolking. Als we kijken naar de werkenden in Rotterdam (die wellicht elders wonen), dan zien we dat zowel de totale werkgelegenheidsgroei als de groei van het aandeel postindustriële beroepen daarbinnen enigszins achterblijft. Kijken we echter naar de in Rotterdam wonende beroepsbevolking, dan zien we dat er wél sprake is van een groeiend aandeel postindustriële beroepen maar vrijwel alleen in de onderste regionen van de arbeidsmarkt (geschoolde en ongeschoolde dienstenberoepen). Waar de tendens van postindustrialisering van de arbeidsmarkt in Amsterdam samengaat met polarisatie zien we in Rotterdam eerder een tendens tot degradatie in de postindustriële beroepen (o.a. door een scherpe daling van het aandeel personen met een professioneel dienstenberoep).

Het verschil in de ontwikkelingstendenties op de stedelijke arbeidsmarkten in Amsterdam en Rotterdam is te verklaren vanuit het karakter van beide steden. Amsterdam met enerzijds zijn concentratie van hoogwaardige commerciële en financiële activiteiten en anderzijds zijn uitgebreide toerisme en funindustry "...the closest thing to a global city the Netherlands has to offer" (Kloosterman 1996: 471). Aangezien het bij de expansie van de postindustriële beroepen zowel om hoog-als om laagwaardige functies gaat, gaat de tendens tot postindustrialisering van de beroepenstructuur in Amsterdam gepaard met polarisatie. Dat we in Amsterdam - anders dan in Rotterdam - ook onder de in de stad wonende beroepsbevolking een groei van het aandeel hoogwaardige dienstenberoepen zien, heeft te maken met het karakter van de stad. Amsterdam staat immers ook bekend als een aantrekkelijke woonplaats voor de economische en culturele elite. Rotterdam heeft die aantrekkingskracht minder, waardoor de hooggeschoolde elite - ook als men in Rotterdam werkt - er vaker toe neigt om elders te gaan wonen. Hoewel zij de hoogwaardige functies in de Rotterdamse economie innemen, wonen zij liever buiten de stad. De Rotterdamse beroepsbevolking, dat wil zeggen degenen die er wonen, is daarentegen sterk aangewezen op de onderste segmenten van de stedelijke arbeidsmarkt. Voorzover er in de context van de regio Rotterdam sprake is van polarisatie, gaat het om de groeiende tegenstelling tussen enerzijds de nog in Rotterdam wonende beroepsbevolking - die als men al werkt veelal is aangewezen op laaggeschoold werk in de dienstensector en de resterende industrie - en anderzijds de in de omliggende randgemeenten wonende economische elite van de stad.

\subsection{SPANNINGEN OP DE STEDELIJKE WONINGMARKT}

De selectieve migratieprocessen van en naar de grote steden - het vertrek van welgestelde gezinnen en autochtonen uit de stad en de komst van migranten en minderheden naar de stad - zijn voor een belangrijk deel het gevolg van het verschil in samenstelling van de woningvoorraad in de steden én de omliggende gebieden. Daarnaast is de concentratie van minderheden in de grote steden waar- 
schijnlijk ook een zelfstandige factor die de trek naar de stad van deze groepen versterkt ('kettingmigratie').

De stedelijke woningvoorraad bestaat veel meer dan landelijk gemiddeld uit sociale woningbouw, uit goedkope woningen, uit flat- en portiekwoningen en uit oudere woningen (vgl. tabel 2.2).

In de literatuur wordt vaak gewezen op de voordelen van het grote aandeel relatief goedkope woningen in de Nederlandse steden. Hierdoor bieden de steden ruime mogelijkheden voor werklozen en lage inkomensgroepen om een fatsoenlijk huis tegen een redelijke prijs te vinden. In de tweede plaats bieden de steden

Tabel 2.2 Kenmerken van de woningvoorraad in Amsterdam, Rotterdam en Nederland (1998 en 2003)

\begin{tabular}{|c|c|c|c|c|c|c|}
\hline & & 1998 & & & 2003 & \\
\hline & A'dam & R'dam & Ned & $A^{\prime}$ dam & R'dam & Ned \\
\hline Type woning (in \%) & & & & & & \\
\hline Eengezinswoningen & 11 & 21 & 69 & 12 & 22 & 71 \\
\hline Sociale huur & 54 & 59 & 37 & 54 & 55 & 35 \\
\hline Koopwoningen & 16 & 24 & 51 & 17 & 23 & 54 \\
\hline Koop- en huurprijzen (in & & & & & & \\
\hline huur laag & 58 & 47 & 26 & 52 & 42 & 24 \\
\hline huur midden & 19 & 21 & 17 & 21 & 24 & 16 \\
\hline huur hoog & 8 & 8 & 6 & 9 & 8 & 6 \\
\hline koop laag & 3 & 9 & 10 & 3 & 11 & 11 \\
\hline koop midden & 4 & 8 & 18 & 5 & 8 & 17 \\
\hline koop hoog & 8 & 7 & 23 & 10 & 8 & 26 \\
\hline Bouwjaar (in \%) & & & & & & \\
\hline Voor 1944 & 56 & 38 & 24 & 54 & 36 & 22 \\
\hline $1945-1970$ & 22 & 29 & 31 & 21 & 28 & 29 \\
\hline $1971-1990$ & 15 & 25 & 36 & 14 & 24 & 34 \\
\hline 1991 en later & 7 & 7 & 10 & 11 & 12 & 15 \\
\hline
\end{tabular}

Toelichting:

1998 huur: goedkoop = tot 702 gld., midden $=702$ tot 939 gld., duur $=$ vanaf 939 gld .

1998 koop: goedkoop = tot 210.000 gld., midden $=210.00$ tot 300.000 gld., duur $=$ vanaf 300.000 gld .

2003 huur: goedkoop $=$ tot 358 euro, midden $=358$ tot 479 euro, duur $=$ vanaf 479 euro

2003 koop: goedkoop = tot 150.200 euro, midden $=$ duur 150.200 tot 214.500 euro, duur $=$ vanaf 214.500 euro

Bron: Gegevens 1998 uit Van der Woude et al. 2001 (bron: WBO), behalve eengezinswoningen in Rotterdam 1998 en 2003: ter beschikking gesteld door cos. Gegevens 2003 Amsterdam en Rotterdam: COS en O\&S; Nederland (2003=2002): gegevens Ministerie van VROM (bron: woningvoorraadbestand), Gegevens bouwjaar (voor 1998 en 2003) uit ABF Research, Syswov. 
hierdoor mogelijkheden voor immigranten en andere starters op de woningmarkt om relatief goedkope woonruimte te vinden. Ten slotte is de goedkope woningvoorraad in de steden zo groot dat ook de hogere inkomens er gebruik van maken. Betoogd wordt wel dat dit laatste een effectief mechanisme is om extreme vormen van residentiële segregatie naar inkomen en etnische herkomst te vermijden - hoewel de etnische segregatie in een stad als Rotterdam niet minder is dan in andere West-Europese steden (vgl. Dieleman en Kloosterman 2000: 192).

Tegenover deze voordelen van de grote goedkope woningvoorraad in de steden staan echter ook nadelen. Het belangrijkste is wel dat het stedelijke woningaanbod niet aansluit bij de vraag naar woningen die juist gericht is op duurderde koopwoningen, eengezinswoningen en op nieuwbouw. De woningvoorraad uit de randgemeenten rond de grote steden voldoet veel beter aan de woonwensen van de hedendaagse burger, met als gevolg dat de welgestelden de stad verlaten, terwijl hun plaats in de stad wordt ingenomen door een minder koopkrachtig publiek - onder wie veel migranten en minderheden - die juist worden aangetrokken door de goedkope woningen in de steden (Van de Wouden et al. 2001:37-49).

Tabel 2.2 geeft enkele kerncijfers over de woningvoorraad in Amsterdam en Rotterdam en in Nederland weer. Uit de tabel kan ook worden afgelezen of de samenstelling van de woningvoorraad in Amsterdam en Rotterdam de afgelopen vijf jaar (tussen 1998 en 2003) weinig is veranderd. Vooraf moet echter worden opgemerkt dat de veranderingen in de woningvoorraad bijna per definitie zeer marginaal zijn, omdat het bestaande woningenbestand natuurlijk niet van de een op andere dag gewijzigd kan worden. Deze realiteit wordt nog te weinig onderkend in het huidige herstructeringsoffensief. De grote steden voeren momenteel een beleid van stedelijke herstructurering, waarmee geprobeerd wordt de woningvoorraad meer in overeenstemming te brengen met de dominante woonwensen (duurder, meer koop, meer eengezinswoningen).

In de tabel kan worden afgelezen in hoeverre deze gewenste ontwikkelingen de afgelopen jaren al gerealiseerd zijn in Amsterdam en Rotterdam. In de eerste plaats springt de afwijkende samenstelling van de grootstedelijke woningvoorraad duidelijk in het oog. In Amsterdam én Rotterdam bestond in 2003 meer dan de helft van de totale woningvoorraad uit sociale woningbouw, het aandeel koopwoningen lag in beide steden op minder dan een kwart. Het aandeel eengezinswoningen lag in Amsterdam in 2003 op 11 procent en in Rotterdam tweemaal zo hoog (22\%). Ook blijkt duidelijk dat het aandeel goedkope huurwoningen in de beide steden zeer veel hoger ligt dan landelijk gemiddeld. Omgekeerd ligt het aandeel dure woningen (huur én koop) in de grote steden zeer veel lager dan gemiddeld in Nederland.

Wat in de tabel opvalt, is dat het aandeel dure woningen in Amsterdam - ondanks de bijna spreekwoordelijke Amsterdamse grachtengordel als woonplaats van de stedelijke elite - niet wezenlijk hoger ligt dan in Rotterdam. In 1998 was het aandeel dure woningen in beide steden vrijwel gelijk, in 2003 lag het aandeel dure 
woningen in Amsterdam iets hoger dan in Rotterdam. Aan de andere kant telt Rotterdam beduidend meer goedkope koopwoningen dan Amsterdam. Waarschijnlijk gaat het hier zowel om vroegere corporatiewoningen, die aan particulieren zijn verkocht en nu door de eigenaar worden bewoond, als om goedkoop particulier woningbezit dat door de eigenaren wordt verhuurd. Bij deze laatste categorie gaat het deels om de kleine huisjesmelkers die in een stadsdeel als Charlois zoveel overlast bezorgen. In ieder geval komt dit goedkope particuliere woningbezit in Rotterdam vaker voor dan in Amsterdam. Per saldo kan men echter niet zeggen dat de woningvoorraad in de ene stad meer divers is dan in de andere als we kijken naar de verschillende prijsklassen. In Rotterdam is het middensegment van de woningvoorraad (huur én koop) wat groter dan in Amsterdam, terwijl in Amsterdam zowel de onderkant als de bovenkant van de woningmarkt iets groter is dan in Rotterdam. Dit laatste is echter alleen het geval in 2003. Vergelijkt men de cijfers uit beide jaren, dan valt op hoe weinig er in vijf jaar tijd verandert in de woningvoorraad. In Amsterdam is het aandeel duurdere woningen licht gestegen $(+3 \%)$, zoals wordt beoogd door het beleid van stedelijke vernieuwing. In Rotterdam bleef het aandeel dure woningen min of meer gelijk $(+1 \%)$. Ook het aandeel eengezinswoningen bleef de afgelopen vijf jaar in beide steden min of meer stabiel. Als er in het kader van stedelijke vernieuwing al meer eengezinswoningen worden gebouwd, valt dit kennelijk in het niet bij de bouw van andere (meer stedelijke!) woningtypen.

Dit alles wil echter geenszins zeggen dat er op het gebied van de woningmarkt en huisvesting geen verschillen zijn tussen Rotterdam en Amsterdam. Deze verschillen zijn er wel, maar ze liggen kennelijk niet zozeer bij het aanbod van woningen (de bestaande woningvoorraad) maar bij de vraag naar woningen in Amsterdam en Rotterdam. Hiervoor hebben we al opgemerkt dat Amsterdam ondanks de gebruikelijke stedelijke problemen een aantrekkelijke woonplaats is - ook voor beterverdienenden. Zo heeft Amsterdam haar al gememoreerde grachtengordel waar de stedelijke elite zich thuis voelt. Rotterdam heeft zulke buurten niet of in veel mindere mate. Maar niet alleen (delen van) de Amsterdamse binnenstad zijn een gewilde woonplek, hetzelfde geldt inmiddels ook voor de oudere wijken rond de binnenstad. Het gevolg van dit alles is dat Amsterdam, anders dan Rotterdam, een vrij gespannen woningmarkt kent. Amsterdam kent een veel grotere koopkrachtige vraag naar woningen dan Rotterdam. Deze spanning op de woningmarkt breidt zich langzaam uit van de Amsterdamse binnenstad naar andere oudere stadswijken binnen de Amsterdamse ring en in bepaalde gevallen zelfs naar de nieuwere (vroeg-naoorlogse) wijken buiten de ring.

Deze gespannen situatie op de woningmarkt en de voortdurende koopkrachtige vraag naar woningen in Amsterdam heeft grote gevolgen. Het betekent bijvoorbeeld dat woningzoekenden met enig financieel vermogen misschien niet op toplocaties in de Amsterdamse binnenstad terecht kunnen, maar als alternatief daarvoor een huis in de omliggende oude wijken kopen. Het gevolg hiervan is dat huizen in de oude wijken door hun nieuwe bewoners worden opgeknapt en dat gaandeweg de hele buurt verbetert. Als de huizen in de buurt daardoor ook duur- 
der worden, zullen ze misschien onbetaalbaar worden voor nieuwe starters op de woningmarkt. Zij wijken op hun beurt uit naar nog verder van het centrum gelegen wijken en buurten, waar misschien dezelfde mechanismen optreden.

Kortom, door de aantrekkelijkheid van Amsterdam als stad is er sprake van een voortdurende spanning op de woningmarkt, die niet beperkt blijft tot het stadscentrum, maar zich gaandeweg over de hele stad verspreidt. In Rotterdam is de vraag naar woningen veel minder. Het probleem van Rotterdam op het gebied van de woningmarkt is niet zozeer een tekort, maar een kwalitatief overschot aan ongewilde woningen en de daaruit voortvloeiende leegstand.

Deze zeer uiteenlopende ontwikkelingen op de woningmarkten hebben ook gevolgen voor de manier waarop in beide steden met sociale problemen kan worden omgegaan. Twee concrete voorbeelden mogen dit illustreren. In de zomer van 2003 begon de Rotterdamse dagelijks bestuurder van de deelgemeente Charlois, Dominic Schrijer, de discussie over de zijns inziens onhoudbare situatie in zijn deelgemeente. Deze problemen zouden onder meer veroorzaakt worden door de irreguliere vestiging van groepen die geen toegang hebben tot de reguliere arbeidsmarkt, zoals drugsgebruikers, dealers, andere kleine criminelen, en illegale vreemdelingen. Deze vestigen zich veelal in huizen van particuliere eigenaren. Illegale vreemdelingen, bijvoorbeeld, hebben geen toegang tot de sociale zekerheid en de formele arbeidsmarkt en zijn daarom aangewezen op hennepkwekerijen, kleine criminaliteit, prostitutie of andere activiteiten die veel overlast veroorzaken in de buurt. Vervolgens vroegen wij in Amsterdam of zij ook problemen omtrent de irreguliere vestiging van illegalen ervaren. Volgens onze zegslieden is dit niet het geval, maar vooral de daarvoor opgegeven argumenten zijn het vermelden waard.

In het stadsdeel Slotervaart, waar ons Amsterdamse onderzoek zich afspeelt, wonen weliswaar veel illegalen, maar zij wonen niet zelfstandig in huizen van particuliere huisjesmelkers. De reden is dat het stadsdeel Slotervaart vrijwel geen particulier huizenbezit kent. De illegalen in Slotervaart wonen veelal in bij familie en worden deels door hen verzorgd, zodat ze niet zijn aangewezen op informele of criminele inkomsten en dus minder overlast veroorzaken (vgl. ook Leerkes et al. 2004). Maar, vroegen wij vervolgens, zie je deze problematiek dan niet in andere Amsterdamse wijken die - net als het Rotterdamse Charlois - wél veel particulier woning bezit kennen? Dit soort wijken zijn er wel in Amsterdam, bijvoorbeeld de Indische Buurt. Hier wordt echter veelal niet aan illegalen verhuurd, omdat het voor de huiseigenaren aantrekkelijker is om aan koopkrachtige yuppies te verhuren.

Tijdens ons onderzoek viel ook op dat men in Charlois zoveel dichtgetimmerde huizen ziet, terwijl dit in Slotervaart eigenlijk niet voorkomt. Toch is er in beide stadsdelen volop sprake van stedelijke vernieuwing en worden er huizen gesloopt en weer opgebouwd. Het verschil is echter dat in Rotterdam voorafgaand aan dit alles veel huizen langdurig worden dichtgetimmerd en in Amsterdam niet. Op zoek naar een verklaring voor dit verschil werd door onze zegslieden weer gewezen op de verschillende woningmarkten in beide steden. In 
Amsterdam komt vanwege de gespannen woningmarkt ook in perifere stadsdelen als Slotervaart weinig of geen leegstand voor. Als er al eens een woning leegstaat of wordt ontruimd, dan zorgt het stadsdeelbestuur er doorgaans snel voor dat de woning opnieuw wordt gebruikt. Voorkomen van leegstand is expliciet beleid in het stadsdeel en dat is ook mogelijk omdat er altijd wel bewoners of organisaties op zoek zijn naar ruimte.

In Rotterdam en zeker in Charlois is de situatie heel anders. Hier is sprake van een overschot aan woningen waarvoor weinig animo bestaat. In leegstaande woonruimtes vinden vervolgens allerlei ongewenste activiteiten plaats (variërend van illegale bewoning tot hasjkwekerijen en drugshandel). Het bestuur van de deelgemeente reageert hierop door de betreffende woningen te ontruimen en er vervolgens een stalen deur voor te plaatsen. In beide gevallen zien we dus dat de algemene verschillen op de woningmarkt in Amsterdam en Rotterdam van invloed zijn op de mogelijkheden voor effectief ingrijpen in wijken en buurten.

Een belangrijke overeenkomst tussen Amsterdam en Rotterdam is dat er in beide steden grootse plannen voor stedelijke herstructurering bestaan. Stedelijke herstructurering, ook wel stedelijke vernieuwing genoemd, beoogt de eenzijdige samenstelling van de woningvoorraad in de grote steden te veranderen en meer algemeen de leefbaarheid en woonkwaliteit in grootstedelijke achterstandswijken te verbeteren.

Uitgangspunt van het beleid van stedelijke herstructurering is dat de concentratie van sociale achterstand in bepaalde stadswijken doorbroken moet worden. De assumptie hierbij is dat de ruimtelijke concentratie van zaken als armoede en werkloosheid een zichzelf versterkend effect zouden hebben. Er zou sprake zijn van buurteffecten. Een voorbeeld hiervan is het idee dat werklozen in buurten met veel werkloosheid en uitkeringsafhankelijkheid minder kans op een baan hebben dan werklozen uit andere buurten, ongeacht hun persoonlijke achtergrondkenmerken en kwaliteiten. Dit buurteffect zou ontstaan doordat werklozen in buurten met veel andere werklozen zich gemakkelijker aanpassen aan hun situatie en niet meer naar werk zoeken óf doordat werkgevers liever geen werkzoekenden uit zo'n buurt aannemen (dit laatste staat bekend als residentiële discriminatie).

Onderzoekers benadrukken overigens dat dergelijke buurteffecten in Nederland, anders dan in de Verenigde Staten waar echte getto's bestaan, nooit zijn aangetoond (Engbersen en Burgers 2001; Engbersen et al. 200o) Desondanks is het al sinds jaren expliciet overheidsbeleid om de eenzijdige bevolkingssamenstelling van grootstedelijke achterstandswijken te doorbreken en het belangrijkste middel daartoe is het veranderen van de samenstelling van de woningvoorraad in deze wijken, die - zoals we zagen - zeer eenzijdig is samengesteld.

Het centrale doel van stedelijke herstructurering is daarmee het realiseren van in sociaal opzicht beter gemengde buurten. Het belangrijkste middel daartoe is het 
creëren van een meer gevarieerd woningbestand. Om dit te realiseren zijn in tal van steden grootschalige herstructureringsprogramma's afgekondigd: deze programma's bestaan doorgaans uit de sloop van een aanzienlijk deel van de goedkope woningvoorraad in de betreffende buurten en de bouw van een (meestal kleiner) aantal duurdere woningen in de wijk. Inmiddels is echter wel duidelijk geworden dat de beschikbaarheid van duurdere en betere woningen in de stedelijke achterstandswijken niet automatisch betekent dat hogere inkomensgroepen daar ook willen wonen. Vandaar dat naast de fysieke herstructurering van deze buurten sprake is van een beleid gericht op sociale verbeteringen in de buurt. Minister Dekker (VROM) verwoordde de samenhang tussen de fysieke en de sociale kant van stedelijke herstructurering als volgt:

“(...) belangrijk (...) is dat stedelijke vernieuwing niet alleen vorm krijgt in stenen en structuren, maar vooral ook in mensen en in de manier waarop ze samenleven in hun buurt. In onze steden staan we voor grote, gecompliceerde opgaven. (...) Bewoners van achterstandswijken willen in de eerste plaats zien dat er echt wat gebeurt: dat de onveiligheid afneemt, dat voorzieningen zoals een huisarts en een buurtwinkel niet verdwijnen, dat de scholen beter presteren, dat de woningen verbeteren en dat de openbare ruimte schoner wordt en heel blijft. Kortom, de buurt moet weer aantrekkelijker worden voor bewoners met diverse achtergronden én inkomens. De middengroepen die de stad nu nog de rug toekeren, kunnen dan voor de stad behouden blijven." 5

Om dit alles te realiseren, zijn in 2003 in totaal 56 stadswijken geselecteerd waar stedelijke vernieuwing met kracht ter hand genomen moet worden, waaronder de beide wijken die in dit onderzoek centraal staan, de Rotterdamse deelgemeente Charlois en het Amsterdamse stadsdeel Slotervaart. Stedelijke vernieuwing heeft al met al het karakter gekregen van een integrale verbetering van stedelijke achterstandswijken. Het gaat niet meer alleen om de verandering van de woningvoorraad en daarmee van de bevolkingssamenstelling van stadsbuurten (het zogenaamde gemengde bouwen).

Het doel is meer algemeen het tegengaan van verloedering en het bevorderen van de leefbaarheid, veiligheid, een kwalitatief betere woonomgeving en uiteindelijk ook een meer evenwichtige bevolkingssamenstelling in de buurt. Wat betreft het oorspronkelijke doel van stedelijke herstructurering - een minder eenzijdige bevolkingssamenstelling van stedelijke achterstandswijken door een combinatie van sloop en gemengd bouwen - kan tenslotte worden opgemerkt dat dit beleid pas op lange termijn de beoogde resultaten kán hebben. Immers, het veranderen van de woningvoorraad in wijken en buurten is een proces van zeer lange adem, dat pas op een termijn van tien, twintig jaar de beoogde demografische resultaten zal opleveren. Zowel in Charlois als in Slotervaart staat bij lokale bestuurders voorop dat men niet op de (onzekere) uitkomsten van dit proces kan wachten en dat er ook nu ingrijpende interventies nodig zijn om verloedering van de buurt te voorkomen en de leefbaarheid en veiligheid te bevorderen. 


\subsection{OVERLAST EN CRIMINALITEIT}

Misschien wel het meest urgente probleem in de hedendaagse grote steden is de veiligheid. In ieder geval in het politieke debat over grootstedelijke ontwikkelingen en problemen neemt de overmaat aan overlast en criminaliteit in de steden een prominente plaats in. Waar het debat over de stad enkele jaren geleden nog primair ging over sociale achterstand, met name in bepaalde stadsbuurten en bij specifieke categorieën onder de stedelijke bevolking, gaat het nu steeds meer over overlast en criminaliteit. Beschikbare gegevens over de geregistreerde criminaliteit wijzen ook uit dat de onveiligheid zeer ongelijk verdeeld is in ons land. In de grote steden ligt het aantal delicten verhoudingsgewijs veel hoger dan landelijk gemiddeld. In Amsterdam ligt het totale aantal delicten relatief gezien (dat wil zeggen, gerelateerd aan het aantal inwoners tussen 12 en 79 jaar) 1,7 maal zo hoog als gemiddeld in Nederland. In Rotterdam is de geregistreerde criminaliteit wat lager dan in Amsterdam, maar ook hier ligt het aantal delicten per duizend inwo-

Tabel 2.3 Aantal delicten per 100.000 inwoners (tussen 12 en 79 jaar) in Nederland en in de politieregio's Amsterdam-Amstelland en Rotterdam-Rijnmond, (1994-2002)

\begin{tabular}{|c|c|c|c|c|c|c|c|}
\hline & 1994 & 1996 & 1998 & 2000 & 2001 & 2002 & $\begin{array}{r}1994 \\
=100\end{array}$ \\
\hline Nederland & & & & & & & \\
\hline Totaal generaal & 10415 & 9362 & 9542 & 10050 & 10384 & 10813 & 104 \\
\hline Wv. Geweld & 532 & 531 & 598 & 700 & 774 & 830 & 156 \\
\hline Vermogen & 7757 & 6568 & 6570 & 6834 & 7031 & 7192 & 93 \\
\hline Vernieling en openb. orde & 1234 & 1344 & 1397 & 1461 & 1476 & 1575 & 128 \\
\hline $\begin{array}{l}\text { Opiumwet } \\
\text { Regio Amsterdam-Amstelland }\end{array}$ & 35 & 58 & 60 & 58 & 79 & 96 & 274 \\
\hline Totaal generaal & 18035 & 16602 & 17338 & 19835 & 19812 & 18564 & 103 \\
\hline Wv. Geweld & 1235 & 1396 & 1334 & 1726 & 1821 & 1773 & 144 \\
\hline Vermogen & 14878 & 12721 & 13201 & 14349 & 14073 & 12991 & 87 \\
\hline Vernieling en openb. orde & 1144 & 1334 & 1229 & 1841 & 1863 & 1787 & 156 \\
\hline $\begin{array}{l}\text { Opiumwet } \\
\text { Regio Rotterdam-Rijnmond }\end{array}$ & 152 & 153 & 257 & 235 & 325 & 353 & 232 \\
\hline Totaal generaal & 12464 & 9954 & 11050 & 11662 & 12148 & 15069 & 121 \\
\hline Wv. Geweld & 675 & 663 & 809 & 903 & 1070 & 1415 & 210 \\
\hline Vermogen & 9558 & 6575 & 7211 & 7789 & 8213 & 9816 & 103 \\
\hline Vernieling en openb. orde & 1038 & 1379 & 1600 & 1566 & 1466 & 1846 & 178 \\
\hline Opiumwet & 33 & 23 & 46 & 35 & 72 & 126 & 382 \\
\hline
\end{tabular}

Toelichting:

Totaal generaal: Alle misdrijven ter kennis gekomen van de politie door aangifte van burgers of door eigen opsporing. Alleen delicten waarvan proces-verbaal is opgemaakt (incl. wegenverkeerswet etc.). 
ners 1,4 maal zo hoog als gemiddeld in Nederland. Met name geweldsmisdrijven komen verhoudingsgewijs in de grote steden beduidend vaker voor dan elders in Nederland (vgl. tabel 2.3).

De bevinding dat de criminaliteit (althans gemeten naar het aantal formeel bij de politie geregistreerde delicten per duizend inwoners) in Rotterdam lager ligt dan in Amsterdam is enigszins verrassend, zeker gezien alle discussies die de afgelopen jaren in Rotterdam over dit onderwerp zijn gevoerd. Rotterdamse buurten als Spangen, de Tarwewijk en de Millinxbuurt (buurt in de Tarwewijk) zijn de afgelopen jaren landelijk bekend geworden als 'erkende probleembuurten' als het gaat om overlast en criminaliteit. Desondanks ligt het aantal delicten in Rotterdam (afgezet tegen het aantal inwoners) ongeveer 20 procent lager dan in Amsterdam. Dit geldt voor vrijwel alle delicten, behalve voor vernieling en openbare orde. Deze laatste delictsoort komt in Rotterdam verhoudingsgewijs even vaak voor als in Amsterdam. Hierna zullen we nog zien dat dit niet alleen voor de steden als geheel geldt, maar ook voor de specifieke probleembuurten (zoals de Tarwewijk in Rotterdam en Overtoomse Veld in Amsterdam).

Er is bij dit alles nog wel een belangrijk verschil tussen de veiligheidssituatie in Amsterdam en in Rotterdam. Terwijl in Amsterdam het aantal delicten de afgelopen jaren (in de periode 2000-2002) geleidelijk aan terugliep, zien we in Rotterdam in dezelfde periode juist een toename van het aantal delicten per duizend inwoners. 


\section{NOTEN}

I Bron: Gemeente Amsterdam, O\&s, Rotterdam: cos, Prognose bevolkingsgroepen Rotterdam 2017. Rotterdam: COS 2003.

Tot voor kort heette dit stadsdeel Slotervaart-Overtoomse Veld.

Bijna de helft (46\%) van alle werkenden in Amsterdam woont buiten de stad. In Rotterdam woont zelfs meer dan de helft (53\%) van alle werkenden buiten de stad. Gegevens: CBS, ЕВB (2001). Geciteerd: O\&S, pp. 72.

4 Gegevens: Nyfer, Atlas voor gemeenten 2003. Geciteerd: O\&S, pp. 70. Speech van minister Dekker (VROM) op de conferentie 'Sociaalfysieke krachtlijnen van de stedelijke vernieuwing’, 4 december 2003 (www.vrom.nl). 


\section{ONDERZOEKSBUURT OVERTOOMSE VELD}

\subsection{DE BUURT: ACHTERGROND EN BEWONERS}

De buurt Overtoomse Veld behoort tot het stadsdeel Slotervaart, dat op zijn beurt weer tot de zogenaamde Westelijke Tuinsteden wordt gerekend. De Westelijke Tuinsteden is het hele gebied ten westen van de Amsterdamse Ring (Aro) en omvat vier verschillende stadsdelen. Naast Slotervaart zijn dat de stadsdelen Bos en Lommer, Geuzenveld/Slotermeer en Osdorp. Met bijna 16o duizend bewoners vormt dit deel van Amsterdam een forse stad op zich, qua omvang vergelijkbaar met Amersfoort. De A1o vormt in Amsterdam de scheidslijn tussen de oude binnenstad en de naoorlogse stadsuitbreidingen, maar volgens Paul Scheffer (2004) vormt de A1o in toenemende mate ook een sociale scheidslijn in de stad:

"Voor Amsterdam zouden we kunnen zeggen dat zich steeds meer het beeld opdringt van een stad binnen en een stad buiten de ringweg. De Aro vormt niet alleen een fysieke barrière tussen de vooroorlogse en naoorlogse stad, maar ook meer en meer een sociale scheidslijn.” ${ }^{1}$

Overtoomse Veld is een buurt met krap io duizend inwoners, het hele stadsdeel Slotervaart telt 44 duizend inwoners (alle cijfers in tabel 3.1). Overtoomse Veld is een typisch voorbeeld van een naoorlogse stadsuitbreidingswijk, indertijd gebouwd volgens het concept van de 'tuinstad'. Volgens deze filosofie moest er voldoende ruimte, licht en groen in de wijk zijn, terwijl de wijk anderzijds ook zo omvangrijk moest zijn dat er voldoende draagvlak is voor voorzieningen.

Dit alles werd gerealiseerd door veel middelhoge flats met vier of vijf bouwlagen te bouwen. Direct na de bouw waren deze woningen attractief voor gezinnen met kinderen, die de krappe en drukke Amsterdamse binnenstad wilden ontvluchten en grotere woningen wilden hebben. Inmiddels gelden de naoorlogse buurten echter allang niet meer als attractief. Autochtone gezinnen die zich dat financieel konden permitteren, hebben de Westelijke Tuinsteden op grote schaal verlaten en zijn naar buiten de stad verhuisd. Hun plaats werd veelal ingenomen door allochtone gezinnen en andere lage inkomensgroepen, die worden aangetrokken door de goedkope, maar toch ruime woningen in dit deel van de stad.

Overtoomse Veld is een typisch voorbeeld van deze ontwikkeling. De buurt ligt ingeklemd tussen de Aio en de spoorlijn. De buurt stamt uit de late jaren vijftig, vroege jaren zestig en bestaat grotendeels uit woonblokken met vier bouwlagen, met portieken waaraan steeds acht woningen liggen, en die grotendeels het bezit zijn van woningcorporaties (sociale verhuur). Overtoomse Veld telt veel relatief grote woningen. Twee derde van alle woningen in de buurt telt vier of meer kamers, in heel Amsterdam is dat slecht bij één op de drie woningen het geval. Naast de huurprijs is dat waarschijnlijk een van de redenen waarom de buurt vooral in trek is bij (veelal grote) Marokkaanse gezinnen. Eigen woningbezit komt in Overtoomse 
Veld slechts sporadisch voor; wel is er - naast de sociale verhuur - nog een aanzienlijk deel particuliere verhuur. Autochtone Nederlanders vormen nog slechts een minderheid onder de buurtbewoners (28\%). Bijna twee derde van de bevolking

Tabel 3.1 Woningvoorraad en bewoners in Amsterdam, stadsdeel Slotervaart en diverse buurten (2003)

\begin{tabular}{|c|c|c|c|c|c|c|}
\hline & $\begin{array}{c}\text { Sloter- } \\
\text { vaart } \\
\text { R85 }\end{array}$ & $\begin{array}{c}\text { Overtoom- } \\
\text { se Veld } \\
\text { R86 }\end{array}$ & $\begin{array}{l}\text { Westland- } \\
\text { gracht } \\
\text { R87 }\end{array}$ & $\begin{array}{l}\text { Sloter-/ } \\
\text { Riekerp. } \\
\text { R88 }\end{array}$ & $\begin{array}{c}\text { Stadsdeel } \\
\text { Sloter- } \\
\text { vaart }\end{array}$ & $\begin{array}{l}\text { Totaal } \\
\text { Amster- } \\
\text { dam }\end{array}$ \\
\hline Woningvoorraad & & & & & & \\
\hline Totaal & 6964 & 3860 & 2818 & 5295 & 18937 & 374952 \\
\hline wv. (in \%) Eigenaar/bewoner & 19,1 & 5,8 & 18,4 & 49,8 & 24,9 & 17,2 \\
\hline Sociale verhuur & 65,7 & 61,7 & 52,1 & 20,6 & 50,3 & 54,4 \\
\hline Particuliere verhuur & 15,2 & 32,5 & 29,5 & 29,5 & 24,9 & 28,4 \\
\hline wv. (in \%) $1+2$ kamers & 12,9 & 19,9 & 15,9 & 1,9 & 11,7 & 31,0 \\
\hline 3 kamers & 30,8 & 13,3 & 43,5 & 24,2 & 27,3 & 34,7 \\
\hline 4 kamers & 42,3 & 50,0 & 37,1 & 63,9 & 49,1 & 24,9 \\
\hline 5 en meer kamers & 14,0 & 16,8 & 3,5 & 10,0 & 11,9 & 9,4 \\
\hline $\begin{array}{l}\text { Gemiddelde woningbezetting } \\
\text { Bewoners naar leeftijdsgroepen }\end{array}$ & 2,26 & 2,49 & 1,98 & 2,54 & 2,34 & 1,96 \\
\hline Totaal & 15706 & 9622 & 5566 & 13453 & 44347 & 736045 \\
\hline wv. (in \%) Mannen & 46,7 & 48,9 & 49,4 & 49,7 & 48,4 & 49,3 \\
\hline Vrouwen & 53,3 & 51,1 & 50,6 & 50,3 & 51,6 & 50,7 \\
\hline wv. (in \%) 0-19 jaar & 23,9 & 33,4 & 21,4 & 28,1 & 26,9 & 21,0 \\
\hline 20-34 jaar & 20,3 & 24,5 & 29,8 & 15,8 & 21,0 & 27,0 \\
\hline 35-49 jaar & 20,5 & 19,0 & 22,2 & 33,6 & 24,4 & 25,0 \\
\hline $50-64$ jaar & 14,3 & 11,3 & 13,0 & 14,5 & 13,6 & 15,3 \\
\hline 65 jaar e.o. & 21,0 & 11,8 & 13,6 & 8,0 & 14,1 & 11,6 \\
\hline Gezinnen & 39,9 & 40,7 & 30,4 & 51,9 & 42,0 & 30,1 \\
\hline $\begin{array}{l}\text { Alleenstaanden } \\
\text { Bewoners naar etnische groepen }\end{array}$ & 60,1 & 59,3 & 69,6 & 48,1 & 58,0 & 69,9 \\
\hline wv. (in \%) Nederlanders & 50,4 & 28,6 & 46,9 & 66,0 & 50,0 & 51,9 \\
\hline Zuid-Europeanen & 2,2 & 2,0 & 2,5 & 2,3 & 2,2 & 2,4 \\
\hline Overig west. landen & 7,2 & 5,2 & 8,9 & 8,8 & 7,5 & 9,7 \\
\hline Surinamers & 8,5 & 8,4 & 7,7 & 8,3 & 8,3 & 9,8 \\
\hline Antillianen & 0,7 & 0,8 & 1,2 & 1,1 & 0,9 & 1,7 \\
\hline Turken & 7,8 & 13,9 & 7,3 & 2,7 & 7,5 & 5,0 \\
\hline Marokkanen & 13,7 & 30,5 & 12,3 & 2,8 & 13,9 & 8,3 \\
\hline Overig niet-west. landen & 9,4 & 10,6 & 13,1 & 8,0 & 9,7 & 11,3 \\
\hline Totaal minderheden (excl. Z-E) & 40,1 & 64,1 & 41,7 & 22,9 & 40,3 & 36,0 \\
\hline
\end{tabular}

Bron: Gemeente Amsterdam, Dienst O\&S 
(64\%) van Overtoomse Veld behoort tot de etnische minderheden. Wat vooral opvalt, is het grote aandeel Marokkanen in de buurt (30\% versus $8 \%$ gemiddeld in Amsterdam).

Overtoomse Veld kreeg eind jaren negentig landelijke bekendheid vanwege problemen met Marokkaanse jongeren uit de buurt. Enigszins ongelukkig politieoptreden liep in april 1998 uit op een ware opstand van Marokkaanse jongeren op en rond het August Allebéplein, het centrum van de buurt. Hoewel de rellen slechts één avond duurden, zorgde het incident voor veel media-aandacht voor Amsterdam-Nieuwwest en zijn Marokkaanse jeugd. De rellen rond het Allebéplein zijn achteraf uitvoerig geëvalueerd (vgl. Muller 1998; Van Gemert en Fleisher 2002: 19-20; Van Fogteloo en Van Holst Pellikaan 2003). De algemene conclusie van de onderzoeken was dat de rellen niet op zichzelf stonden, maar tekenend waren voor de indertijd zeer verstoorde verhoudingen tussen Marokkaanse jongeren aan de ene kant en diverse instanties in het stadsdeel (met name de politie, maar ook lokale politiek en middenstand) aan de andere. Voor het (net aangetreden) nieuwe stadsdeelbestuur waren de rellen de aanleiding om samen met andere instanties en partijen in de wijk de handen ineen te slaan en te pogen niet alleen de Marokkaanse jongeren uit de buurt weer in het gareel te krijgen, maar meer algemeen om beter contact te krijgen met de Marokkaanse gemeenschap en de buurt te verbeteren.

\subsection{BEWONERS EN PROFESSIONALS OVER DE BUURT ${ }^{2}$}

Wanneer men met bewoners en vertegenwoordigers van diverse instanties uit Overtoomse Veld praat, krijgt men een overwegen negatief beeld van de buurt. Gesproken wordt van 'getto-achtig', 'Marokkaanse buurt' of van een 'doodlopende straat'. Volgens Eva van Kempen, die uitvoerig onderzoek in Overtoomse Veld deed, hoort men echter soms ook positieve geluiden over de buurt. Oudere bewoners (autochtonen en allochtonen) refereren aan de 'goede oude tijd', toen de buurt er nog goed verzorgd uitzag en de diverse etnische groepen in harmonie met elkaar samenleefden. Recentere allochtone bewoners die vanwege de grote huizen naar Overtoomse Veld verhuisden, zien dat nog steeds als een positieve kant van de buurt. Verder noemen sommige allochtone bewoners de sociale contacten en de aanwezigheid van etnische voorzieningen - in de eerste plaats de moskee bij het August Allebéplein - als positieve kanten van de buurt.

In het algemeen overweegt echter de negatieve beeldvorming over Overtoomse Veld. Van Kempen onderscheidt daarbij de volgende facetten. In de eerste wordt de buurt als onveilig gezien. Bijna alle respondenten van Van Kempen hebben incidenten als bedreiging, geweld, overvallen of inbraak aan den lijve meegemaakt. Vooral Marokkaanse jongeren tussen 15 en 25 jaar worden als oorzaak van de onveiligheid in Overtoomse Veld aangemerkt. Sommige Marokkaanse jongeren, die ook zijn geïnterviewd, geven de schuld echter aan de pers vanwege de negatieve beeldvorming over de buurt na de rellen van 1998. Vuil op straat is een tweede, vaak genoemd probleem in Overtoomse Veld. De oorzaak hiervan wordt 
gezocht in het feit dat de buurt relatief veel scholen telt waardoor er overdag veel jongeren rondhangen op straat.

De hoge concentratie minderheden in de buurt wordt ook als negatief gezien, ook door Turkse en Marokkaanse respondenten. Vooral oudere allochtone bewoners spreken veelal geen Nederlands, hetgeen de communicatie in de buurt zeer beperkt. Ook vertellen allochtone buurtbewoners dat ze door de hoge concentratie minderheden vrijwel geen contact met autochtone Nederlanders hebben. Een vierde negatief aspect van Overtoomse Veld is het gebrek aan en lage kwaliteit van voorzieningen in de buurt. Kort na de bouw van de buurt was er een redelijk voorzieningenpeil. Veel winkels zijn echter in de loop der jaren verdwenen en vervangen door kleine allochtone winkels, die echter vaak pakweg dezelfde producten leveren (veel slagers, kruideniers, kappers, enz.). Ooit was er een eigen bioscoop in de buurt, maar die bestaat allang niet meer.

Een vijfde en belangrijke bron van ontevredenheid betreft de huisvesting in de buurt. Zoals gezegd, bestaat het grootste deel van de woningvoorraad in Overtoomse Veld uit portiekwoningen. De trappenhuizen van deze flats, vaak gedeeld door grote gezinnen met een verschillende etnische herkomst, vormen een bron van overlast en ergernis. Verder klagen bewoners over de gebrekkige kwaliteit van de woningen, die vanwege de aangekondigde stedelijke herstructurering al sinds jaren niet of slecht onderhouden worden. De belangrijkste bron van ergernis is echter de zeer langdurige onzekerheid als gevolg van de aangekondigde stedelijke herstructurering volgens welke veel oudere woningen in Overtoomse Veld gesloopt en vervangen zouden worden door duurdere nieuwbouwwoningen. Van Kempen beschrijft hoe al in 1995 de eerste renovatieplannen in Overtoomse Veld werden gelanceerd. Tussentijds (tot begin 2003) is er echter om allerlei redenen concreet nog niet veel gebeurd. Voor bewoners veroorzaakt dit alles veel onzekerheid. Men weet niet wanneer de renovatie zal plaatsvinden en of er daarna nog plek voor hen zal zijn in de buurt.

Een laatste bron van ontevredenheid van bewoners van Overtoomse Veld, zoals bij zoveel andere achterstandswijken, is het zichzelf versterkende effect van de slechte reputatie van de buurt. Vooral Marokkaanse jongeren uit de buurt zeggen de nadelen van het negatieve stigma van de buurt aan den lijve te ondervinden. Als je een Marokkaanse jongere uit Amsterdam-West bent, zo zeggen ze, denken mensen al snel dat je een crimineel bent en krijg je nooit een baan (residentiële discriminatie).

\subsection{DE BELANGRIJKSTE PROBLEMEN IN DE BUURT}

\subsubsection{LEEFBARHEID EN VEILIGHEID}

Het meest evidente probleem in de buurt Overtoomse Veld en elders in het stadsdeel Slotervaart zijn problemen op het gebied van leefbaarheid en veiligheid. Volgens zegslieden in de buurt ligt het probleem vooral bij diverse jeugdgroepen 
die op straat rondhangen en waarbinnen allerlei delinquent gedrag tot ontwikkeling komt. De ‘buurtregisseur' van Overtoomse Veld (door buurtbewoners ook wel wijkagent genoemd) schetste het probleem als volgt:

"De politie heeft nog altijd grote moeite om met deze jeugdgroepen om te gaan. Het is zo ongrijpbaar. Het gaat om jongeren die continu op straat bivakkeren, die daardoor een soort straatinstinct ontwikkeld hebben waardoor ze heel goed aanvoelen hoe ze de macht naar zich toe kunnen trekken. Ze weten precies hoe ze door hun gezamenlijke optreden mensen kunnen intimideren, ze laten zien dat zij bepalen wat er op straat gebeurt. Maar ze kunnen ook door bepaalde subtiliteiten bedreigend zijn voor de politie, waardoor het vooral voor jonge agenten moeilijk is om ze aan te pakken. Je moet 'body' hebben om daarmee om te gaan, en dat heeft niet iedereen. Daarom gaan dingen ook vaak fout, omdat de politie net anders optreedt dan zou moeten. Behalve dat de politie moeite heeft om goed met deze jeugdgroepen om te gaan, worden er ook veel delicten in de wijk gepleegd: berovingen van mobiele telefoontjes, inbraken in scholen waarbij pc's gestolen worden, diefstallen uit auto's, Dit zijn allemaal makkelijk te plegen delicten voor jongeren en de pakkans is minimaal" (Resp. A8)3.

Zowel de politie als lokale politici realiseren zich echter dat de (veelal allochtone) jongeren niet alleen problemen veroorzaken, maar zelf ook een kwetsbare categorie vormen. Stadsdeelvoorzitter Henk Goettsch vertelt dat juist in de periode van snel toenemende werkloosheid - in de jaren tachtig en negentig van de vorige eeuw - veel Marokkaanse gezinnen zich in dit deel van de stad vestigden:

"In die tijd werd de tweede generatie allochtonen geboren. Ik richt mij juist op hen omdat de criminaliteit hier vooral door de allochtone jeugd gepleegd wordt. Ze groeiden op in een situatie dat pa werkloos was, ma de taal niet sprak en het gezin gehuisvest was in een onderkomen dat eertijds weliswaar een verbetering betekende, maar (...) op den duur toch te klein werd. West telde veel goedkope woningen, waar wel in te leven valt, of althans viel, maar die naar moderne maatstaven niet meer door de beugel kunnen."4

Volgens het Jeugdveiligheidsplan 2003-2006, opgesteld door de politie in Amsterdam-West (district 6), ligt het centrale probleem in de wijk in 'het onacceptabele op straat van groepen jongeren tussen 12 en 24 jaar'. Men voegt er echter aan toe:

"Jongeren veroorzaken echter niet alleen overlast maar hebben zelf ook problemen. Bovendien is er voor jongeren weinig ruimte en heerst er vaak een negatieve beeldvorming waardoor (te) snel van overlast wordt gesproken. Het aantal harde kernjongeren schommelt de afgelopen jaren licht maar neemt niet echt af. Hetzelfde geldt voor de licht criminele jongeren.” ${ }_{5}$

De problematiek van overlast en criminaliteit in Overtoomse Veld en de aanpalende buurt Westlandgracht blijkt duidelijk uit gegevens over bij de politie bekende delicten. Het aantal delicten per duizend inwoners ligt in de buurten Overtoomse Veld en Westlandgracht nog beduidend hoger dan het toch al zeer hoge Amster- 
Tabel 3.2 Delicten in het stadsdeel Slotervaart en gemeente Amsterdam, totaal en per duizend inwoners (2000-2002)

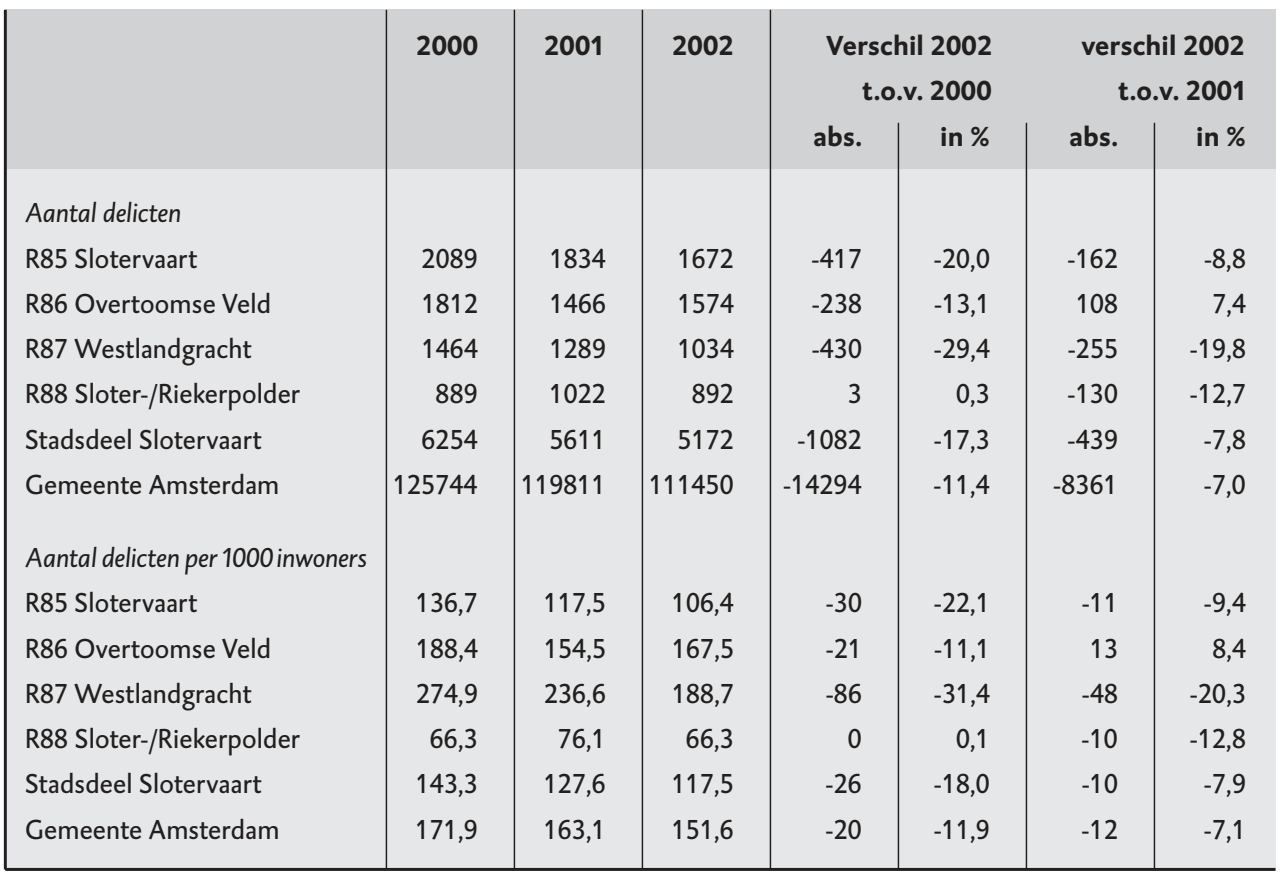

Bron: Dienst O\&S, gemeente Amsterdam

damse gemiddelde. Dit is des te opvallender, omdat veel delicten over het algemeen in de stedelijke uitgaanscentra worden gepleegd en niet in woonbuurten Overtoomse Veld en Westlandgracht. Het aantal delicten per duizend inwoners ligt in beide buurten ook veel hoger dan in vergelijkbare Rotterdamse buurten.

De cijfers laten echter ook zien dat de situatie op het gebied van leefbaarheid en veiligheid de afgelopen jaren wel enigszins is verbeterd. Dit geldt zowel voor heel Amsterdam als voor de betreffende buurten in het stadsdeel Slotervaart. Met name wanneer men de situatie in 2002 vergelijkt met die van twee jaar eerder ziet men duidelijke verbeteringen. In heel Amsterdam daalde het aantal geregistreerde delicten in deze periode met ruim 11 procent. Volgens recente gegevens zette deze verbetering ook in 2003 door. In 2003 was het aantal geregistreerde delicten in Amsterdam afgenomen tot ruim 95 duizend, 17 procent minder dan in 2000. ${ }^{6}$ In het stadsdeel Slotervaart is er met name in de buurt Westlandgracht een scherpe daling van het aantal delicten. In deze buurt daalde het aantal delicten tussen 2000 en 2002 met bijna 30 procent, met dien verstande dat dit aantal hier in 2000 ook wel extreem hoog lag. In Overtoomse Veld daalde het aantal delicten ook, maar minder scherp. Het aantal geregistreerde delicten in Overtoomse Veld daalde tussen 2000 en 2002 met zo'n 13 procent, het aantal delicten per duizend inwoners met ruim 8 procent. 
Tabel 3.3 Delicten naar soorten misdrijven in stadsdeel Slotervaart en gemeente Amsterdam, totaal en per duizend inwoners (2002)

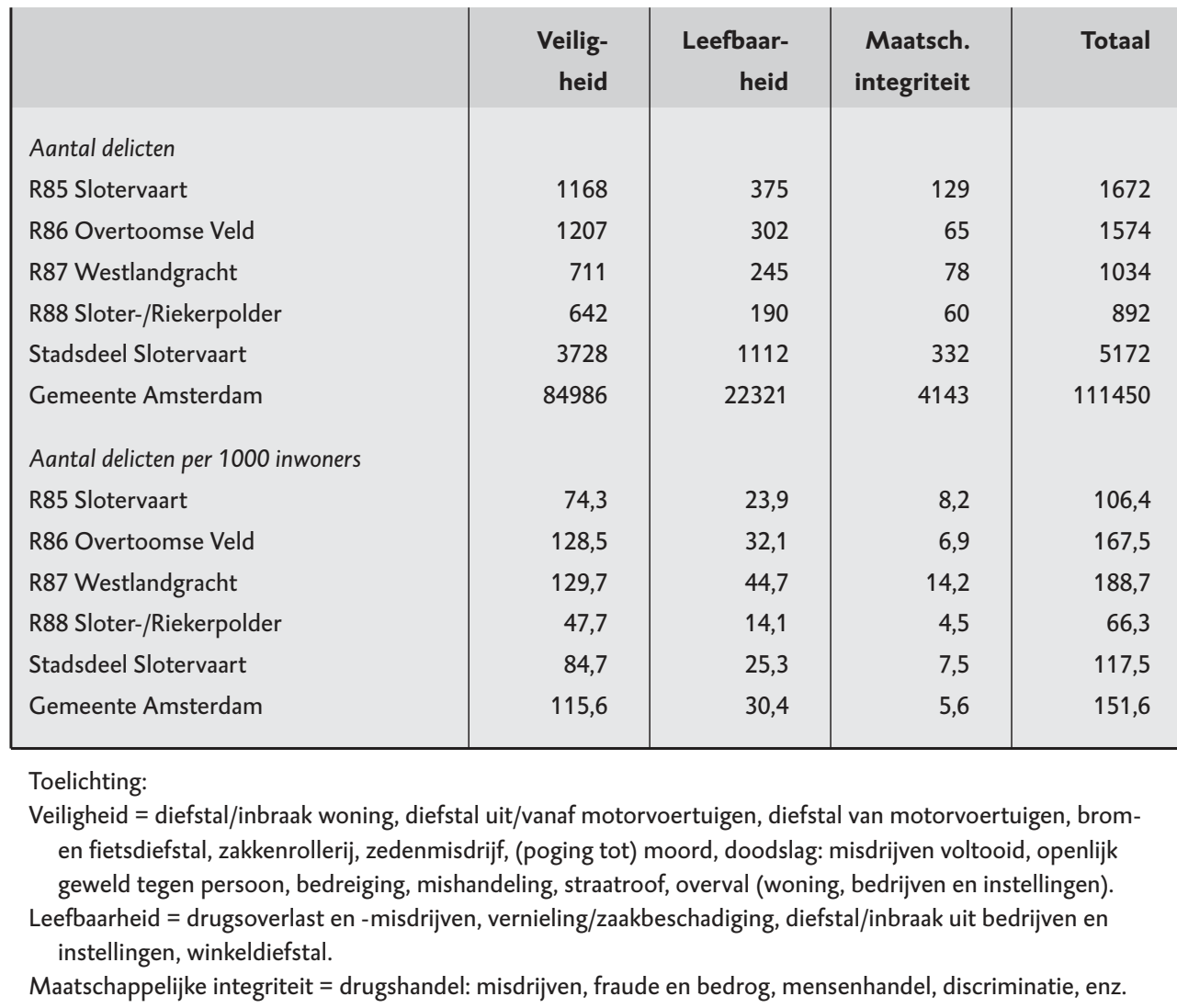

Bron: Dienst O\&S, gemeente Amsterdam (www.os.amsterdam.nl)

Verreweg de meeste gepleegde delicten in Overtoomse Veld betreffen zogenaamde veiligheidsdelicten zoals diefstal en inbraak woning, diefstal van en uit auto's, zakkenrollerij, maar ook geweldsdelicten zoals geweld tegen persoon, bedreiging, mishandeling, straatroof en overvallen. In totaal werden 128 van zulke veiligheidsdelicten per duizend inwoners van Overtoomse Veld geregistreerd. Concreet betekent dit dat gemiddeld één op de acht inwoners van de buurt in 2002 met zo'n delict te maken had.

Desondanks is er sprake van verbetering, niet alleen in het feitelijke aantal delicten, maar ook in de door bewoners ervaren veiligheid in de buurt. Dit wordt wel 'subjectieve veiligheid' genoemd. Dit blijkt uit de zogenaamde Leefbaarheidsmonitor, een enquête die periodiek wordt uitgevoerd in het stadsdeel Slotervaart. Uit tabel 3.4 blijkt duidelijk dat de subjectieve veiligheid in het stadsdeel Slotervaart vooral in de tweede helft van de jaren negentig (tussen 1997 en 2001) dramatisch verslechterde. In 2001 vond ruim 30 procent van de bewoners van 
Tabel 3.4

Aandeel bewoners van Slotervaart dat vindt dat een delict veel voorkomt in de eigen buurt (in \%)

\begin{tabular}{|c|c|c|c|c|c|c|c|c|c|}
\hline & \multicolumn{3}{|c|}{$\begin{array}{c}\text { Stadsdeel } \\
\text { Slotervaart }\end{array}$} & \multicolumn{2}{|c|}{$\begin{array}{l}\text { Overtoomse } \\
\text { Veld }\end{array}$} & \multicolumn{2}{|c|}{$\begin{array}{l}\text { Staalman- } \\
\text { plein }\end{array}$} & \multicolumn{2}{|c|}{$\begin{array}{l}\text { Delfland- } \\
\text { plein }\end{array}$} \\
\hline & 1997 & 2001 & 2003 & 2001 & 2003 & 2001 & 2003 & 2001 & 2003 \\
\hline Fietsendiefstal & 23 & 30 & 27 & 52 & 34 & 27 & 28 & 31 & 23 \\
\hline Diefstal uit auto's & 21 & 41 & 46 & 47 & 55 & 32 & 53 & 64 & 56 \\
\hline Bekladding van muren & 18 & 25 & 23 & 32 & 37 & 35 & 30 & 31 & 34 \\
\hline Overlast van jongeren & 21 & 31 & 27 & 39 & 44 & 31 & 25 & 25 & 30 \\
\hline Inbraak in woningen & 14 & 22 & 21 & 12 & 20 & 22 & 24 & 25 & 19 \\
\hline Beroving op straat & 6 & 17 & 17 & 28 & 23 & 20 & 16 & 14 & 17 \\
\hline Bedreiging & 3 & 12 & 8 & 19 & 11 & 12 & 11 & 12 & 4 \\
\hline Geweldsdelicten & 2 & 8 & 7 & 10 & 13 & 12 & 9 & 12 & 5 \\
\hline Geluidsoverlast verkeer & 28 & 18 & 20 & 22 & 18 & 12 & 29 & 23 & 20 \\
\hline
\end{tabular}

Bron: Leefbaarheidsmonitor Slotervaart/Overtoomse Veld (vgl. SEC april 2001)

Slotervaart dat overlast door jongeren veel voorkomt in hun buurt, meer dan 40 procent van de bewoners vond in 2001 dat diefstal uit auto's veel voorkomt in de buurt. In de buurt Overtoomse Veld waren deze percentages ook in 2001 nog beduidend hoger dan gemiddeld in het stadsdeel. In 2003 vonden over het algemeen wat minder bewoners van Slotervaart dat bepaalde delicten veel voorkomen in hun buurt. Alleen diefstal uit auto's vormt hierop een uitzondering. In Overtoomse Veld ontwikkelde de situatie zich wat minder gunstig dan gemiddeld in het stadsdeel. Bij sommige delicten constateren bewoners een duidelijke verbetering (bijv. bij bedreiging en beroving op straat), bij andere delicten

Figuur 3.1 Aandeel bewoners van Slotervaart dat vindt dat een delict veel voorkomt in de buurt (1997-2003)

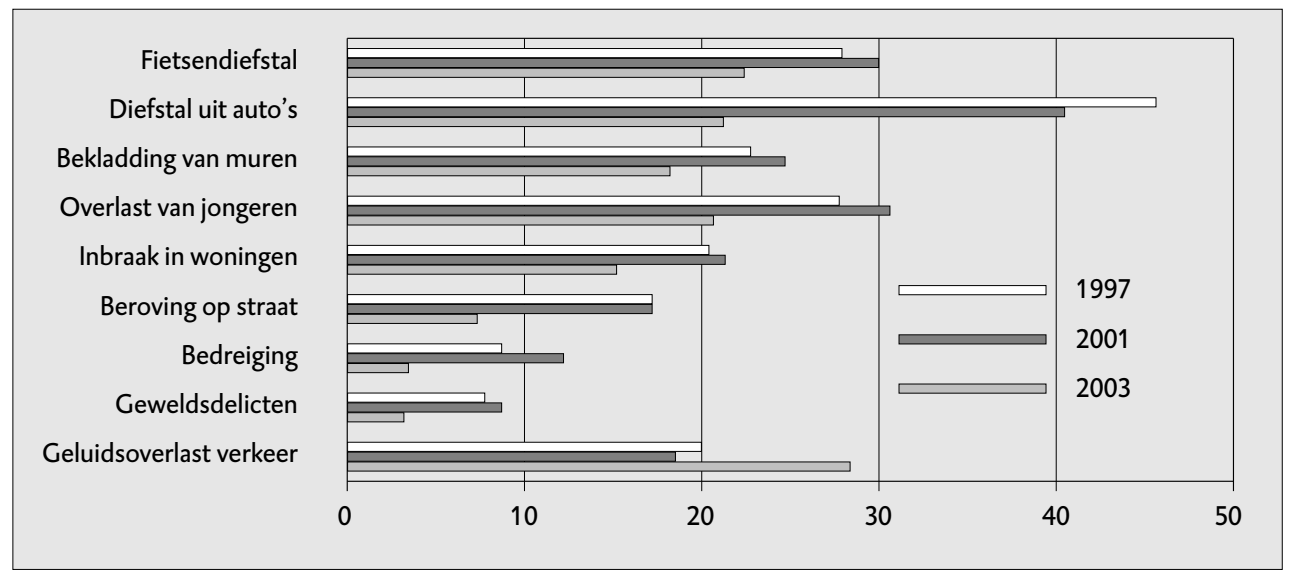

Bron: Leefbaarheidsmonitor Slotervaart/Overtoomse Veld 
verslechterde de situatie verder (overlast door jongeren, diefstal uit auto's). Ook politiefunctionarissen noemen diefstallen uit auto's een ware plaag van de buurt. Het is een delict dat snel en gemakkelijk is gedaan en waaraan zeer veel jongeren zich wel eens wagen.

Bekijkt men de ontwikkeling van de subjectieve veiligheid in het stadsdeel Slotervaart op langere termijn, dan ziet men dat de veiligheidssituatie in de beleving van bewoners in de afgelopen twee jaar wel is verbeterd, maar dat de situatie - afgezien van verkeersoverlast - nog lang niet terug is op het niveau van midden jaren negentig.

\subsubsection{WONINGVOORRAAD EN STEDELIJKE HERSTRUCTURERING}

Amsterdam in het algemeen en de buurt Overtoomse Veld in het bijzonder hebben een eenzijdige woningvoorraad, die steeds minder aansluit bij de vraag naar woningen. De woningvoorraad in Overtoomse Veld bestaat voor 81 procent uit huurwoningen en voor 19 uit koopwoningen. De problemen op de woningmarkt liggen zowel in de aantallen als in het type woningen. Anders dan Rotterdam kent Amsterdam een groot tekort aan woningen. Door de stagnerende nieuwbouw is de woningmarkt nog verder verstopt geraakt en is het voor starters vrijwel onmogelijk geworden een woning te vinden. Daarbij sluit het type woningen vaak niet aan bij de bestaande vraag. Amsterdam, en zeker een buurt als Overtoomse Veld, kent zeer veel goedkope en vaak grote, maar weinig attractieve woningen, terwijl er juist behoefte is aan duurdere en betere woningen. Amsterdam probeert net als andere steden de bestaande woningvoorraad door stedelijke vernieuwing meer in overeenstemming te brengen met de vraag naar woningen.

De centrale doelen van stedelijke vernieuwing in Amsterdam zijn: het verhogen van kwaliteit van woningen door differentiatie van de woningvoorraad (sloop en nieuwbouw, meer eengezinswoningen, enz.), het bevorderen van de leefbaarheid in de stad door een betere woonomgeving, het optimaliseren van het grondgebruik (méér woningen) en een verschuiving van de aandacht en middelen voor stadsvernieuwing van de vooroorlogse stad naar naoorlogse wijken zoals de Westelijke Tuinsteden.7 De eerste plannen voor stedelijke vernieuwing in Overtoomse Veld stammen al uit 1995, maar de uitvoering van deze plannen is aanzienlijk vertraagd door bestuurlijke reorganisaties. In het Stedelijke Vernieuwingsplan van de gemeente Amsterdam uit 1999 werden de Westelijke Tuinsteden als een van de drie aandachtsgebieden voor stedelijke vernieuwing én voor het grotestedenbeleid aangemerkt. Aangezien de Westelijke Tuinsteden zich echter uitstrekken over vier verschillende stadsdelen, vond men het nodig om eerst een nieuwe bestuurlijke eenheid tussen het stedelijke en het stadsdeel niveau te creëren. In 1999 werd daarom Bureau Parkstad opgericht: 
"Parkstad is een samenwerking tussen vier stadsdelen (Slotervaart, Osdorp, Geuzenveld-Slotermeer en Bos en Lommer). We zitten in de vier stadsdelen met dezelfde problematiek: rond dezelfde tijd gebouwd, zelfde bevolking, enzovoorts. En in plaats van dat ieder stadsdeel zijn eigen dingen doet en elkaar daarbij beconcurreert is jaren geleden een initiatief genomen om samen te werken. We noemen dat Parkstad. Parkstad heeft een soort blauwdruk gemaakt van de westelijke tuinsteden en besloten hoe het moet gaan worden. Parkstad fungeert als een soort trechter naar de centrale stad. Bij Parkstad komen de eisen van de centrale stad binnen, zoals de bezuinigingen die eraan zitten te komen, en er wordt dan overleg gevoerd" (Resp. A11) ${ }^{8}$.

Het primaire doel van stedelijke vernieuwing in Overtoomse Veld en elders in de Westelijke Tuinsteden is tweeledig: men wil enerzijds door een grootschalig programma van sloop en nieuwbouw tot een meer gevarieerde woningvoorraad komen en anderzijds het aantal woningen uitbreiden. Dit laatste word t ook wel 'verdichten' genoemd. De gemeente Amsterdam wil meer woningen bouwen op haar grondgebied. Tussen 1998 en 2030 zou het aantal woningen in heel Amsterdam met 90.0oo moeten toenemen (tot circa 455.00o in 2030). Ook het stadsdeel Slotervaart heeft van de centrale stad de opdracht gekregen om te verdichten.

Tabel 3.5 Plannen voor stedelijke herstructurering in de Westelijke Tuinsteden

\begin{tabular}{|c|c|c|c|c|}
\hline Categorie & 2000 & 2015 & $\mathrm{Bij} / \mathrm{af}$ & Door \\
\hline Sociale huur & $41.000(76 \%)$ & $29.000(45 \%)$ & -12.000 & $\begin{array}{l}-13.300 \text { sloop } \\
-3.500 \text { verkoop } \\
-800 \text { omzetting naar dure huur } \\
+5.600 \text { nieuwbouw }\end{array}$ \\
\hline Dure huur & $5.000(9 \%)$ & 10.000 (15\%) & +5.000 & $\begin{array}{l}+4.200 \text { nieuwbouw } \\
+800 \text { omzetting vanuit sociale huur }\end{array}$ \\
\hline Koop & $8.000(15 \%)$ & $26.000(40 \%)$ & +18.000 & $\begin{array}{l}+14.500 \text { nieuwbouw } \\
+3.500 \text { verkoop } \\
\text { huurwoningen }\end{array}$ \\
\hline Totaal & $54.000(100 \%)$ & $65.000(100 \%)$ & +11.000 & \\
\hline
\end{tabular}

Bron: Informatie Amsterdam Parkstad

Stedelijke vernieuwing zal in ieder geval ten koste gaan van de sociale woningbouw in Amsterdam-Nieuwwest. Van het huidige aantal sociale huurwoningen in de Westelijke Tuinsteden (41.0oo woningen) zullen er ruim 13 duizend worden gesloopt. Tegelijkertijd wil men circa 25 duizend nieuwe, veelal duurdere woningen bouwen. Het aantal koopwoningen moet tussen nu en 2015 verviervoudigen (van 8.000 tot 26.000 ). In totaal zouden er door de stedelijke vernieuwing 11 duizend woningen bijkomen in de Westelijke Tuinsteden.

Het doel van stedelijke vernieuwing in Amsterdam-Nieuwwest is nadrukkelijk niet om tot een andere bevolkingssamenstelling van de wijk te komen. Uitgangs- 
punt van het Amsterdamse beleid van stedelijke vernieuwing is dat alle delen van de stad toegankelijk moeten zijn voor alle inkomensgroepen (zij het niet per se overal in dezelfde mate). In elk stadsdeel moet minstens een kwart van de woningen toegankelijk zijn voor lagere inkomens en eveneens minstens een kwart voor hogere inkomensgroepen. Voor een buurt als Overtoomse Veld betekent dit echter dat een aanzienlijk deel van de huidige goedkope woningvoorraad zal moeten verdwijnen en zal worden vervangen door duurdere woningen. Desondanks benadrukt het stadsdeelbestuur dat er voor alle bewoners plaats is in de vernieuwde wijk. Het stadsdeelbestuur heeft de garantie gegeven dat iedereen die na de vernieuwing wil terugkeren in de wijk daartoe de gelegenheid krijgt. Mensen uit de praktijk van stedelijke vernieuwing vragen zich echter af of dit wel mogelijk is:

"Verdichten gaat niet zomaar, dat is het probleem. Bij ons betekent het dat we huizen moeten slopen. Maar je kan natuurlijk niet zomaar zeggen: die en die huizen gaan we slopen. Wij, en ook Parkstad gebruiken de spreuk: 'eerst bouwen, dan slopen'. We vinden dat mensen recht hebben op een vervangende woning. Maar wij hebben toevallig één van de goedkoopste woningvoorraden in heel Amsterdam, dus waar moeten die mensen heen? Dat is heel moeilijk, want wij hebben niet een heel stuk braak liggen, zoals bij Osdorp het geval was. In dat gebied hebben ze allemaal nieuwe woningen neergezet en dan kan je een beetje schuiven met mensen” (Resp. A11).

Volgens haar is er op zijn minst sprake van een spanning tussen enerzijds het inkrimpen van de goedkope woningvoorraad in het stadsdeel Slotervaart en anderzijds het grote aantal bewoners dat is aangewezen op een goedkope woning:

"Waar laat je de mensen? We willen het natuurlijk aardig brengen, maar uiteindelijk moeten veel mensen naar een andere buurt. Hoe zeg je dat tegen mensen? Dat is natuurlijk erg moeilijk” (Resp. A11).

Om bewoners tegemoet te komen, heeft Bureau Parkstad een Sociaal Plan opgesteld, dat bewoners de volgende rechten geeft. ${ }^{9}$

- Voorrang: hoofdhuurders worden 'stadsvernieuwingskandidaat', dat betekent dat zij voorrang krijgen bij het zoeken naar een andere woning. Ze hoeven pas te verhuizen als er een woning is gevonden die passend is bij de gezinsgrootte en inkomen.

- Persoonlijke begeleiding: elke huurder die stadsvernieuwingskandidaat is, krijgt een persoonlijk begeleider. Deze begeleider helpt bij het zoeken naar een andere woning.

- Verhuiskostenvergoeding: hoofdhuurders krijgen een vergoeding van 4.500 euro.

- Huurgewenning: als de huur van het nieuwe huis duurder is dan het oude huis, kan de huurder maximaal 3 jaar korting krijgen op de nieuwe hogere huur.

Ondanks deze tegemoetkoming ligt het echter voor de hand dat een deel van de huidige bewoners van goedkope woningen in de wijk de hogere huren niet zal kunnen betalen en er uiteindelijk zelf voor zal kiezen te vertrekken. De ervaring 
leert overigens dat een deel van de bewoners na stadsvernieuwingsprojecten sowieso niet terugkeert in de oude wijk.

Een ander probleem van de stedelijke vernieuwing in dit deel van Amsterdam is dat het zo lang duurt. De eerste vernieuwingsplannen voor Overtoomse Veld stammen, zoals gezegd, uit het midden van de jaren negentig, maar concreet zijn er door bureaucratische verwikkelingen slechts enkele projecten uitgevoerd. De aangekondigde, maar niet uitgevoerde vernieuwing van de buurt heeft echter grote sociale gevolgen. Bewoners verkeren al sinds jaren in onzekerheid over wat er met hun woning zal gebeuren en of ze nog wel in de wijk kunnen terugkeren. Woningeigenaren plegen vanwege de aangekondigde sloopplannen weinig of geen woningonderhoud meer, met als gevolg de toch al slechte woningen snel in verval raken. Dit leidt vervolgens weer tot meer ontevredenheid en spanningen onder bewoners van de buurt. ${ }^{10}$

\subsubsection{ONDERWIJSACHTERSTANDEN SCHOOLUITVAL}

Een van de grootste gevaren van multiculturele achterstandswijken als Overtoomse Veld is dat sociale achterstand door de tekortschietende schoolresultaten van allochtone kinderen wordt overgedragen van de ene generatie op de andere. Onderzoek laat zien dat allochtone kinderen hun schoolcarrière vaak al met een achterstand beginnen die ze gedurende de basisschoolperiode niet meer inhalen. Het gevolg is dat verhoudingsgewijs veel allochtone kinderen na de basisschool doorstromen naar de lagere schoolsoorten van het middelbaar onderwijs (lager beroepsonderwijs of mavo), al is er de laatste jaren gelukkig ook een grotere doorstroom van allochtone kinderen naar hogere schoolsoorten te zien. Het grootste probleem tijdens de fase van middelbaar onderwijs is de grote voortijdige schooluitval. Het gevolg van dit alles is dat relatief veel allochtone jongeren hun schoolcarrière afsluiten zonder diploma of zonder een minimale startkwalificatie die nodig is om te kunnen functioneren op de arbeidsmarkt. In Overtoomse Veld en elders in het stadsdeel Slotervaart spelen dergelijke problemen volop. Door het vertrek van veel autochtone gezinnen en de komst van allochtonen is de schoolpopulatie in het stadsdeel ingrijpend veranderd. Diverse scholen in Slotervaart kunnen als 'zwarte scholen' gekarakteriseerd worden in de zin dat zij bijna geen autochtone leerlingen meer tellen. Het gevolg hiervan is ook een sterke concentratie van achterstandsleerlingen op de scholen in het stadsdeel. In het Lokaal Onderwijsplan 2002-2006, opgesteld door het stadsdeelbestuur van Slotervaart, wordt de onderwijsproblematiek in het stadsdeel als volgt geschetst.

"Veel scholen hebben hun leerlingenpopulatie zien veranderen en daarmee de gevraagde manier van werken en de aandacht voor specifieke vaardigheden van de leerlingen. Ook de rol van de ouders op school is veranderd. Het is niet meer vanzelfsprekend dat ouders meehelpen op school en betrokken zijn bij het onderwijs aan hun kinderen. Allerlei belemmeringen spelen hierbij een rol: ouders die werken, een taalbarrière, verschillen in visies op de rol van het onderwijs en de rol van de ouders." ${ }_{11}$ 
Ook wordt opgemerkt dat de voorgenomen stedelijke herstructurering een nadelige invloed op het schoolklimaat kan hebben, omdat kinderen en misschien zelfs hele scholen (tijdelijk) moeten verhuizen.

\section{Zwarte scholen}

Precieze gegevens over de etnische herkomst van basisschoolleerlingen in het stadsdeel Slotervaart zijn niet bekend, maar wie op zo'n school rondloopt ziet maar weinig blanke gezichtjes. Volgens de portefeuillehouder onderwijs en welzijn van het stadsdeel, Harro Hoogerwerf, is de onderwijssegregatie op de vele middelbare scholen in het stadsdeel (vmbo, havo/vwo, roc's) nog beduidend verder voortgeschreden dan in het basisonderwijs. Het middelbaar onderwijs in het stadsdeel is 'volledig zwart'. Witte leerlingen worden buiten de wijk naar school gestuurd. Het probleem dat ook allochtone ouders hun kinderen liever niet naar een zwarte school sturen komt volgens Hoogerwerf relatief minder voor. Wel zijn diverse vwo-afdelingen wegens gebrek aan leerlingen gesloten, maar dit zou in de nabije toekomst - door het stijgende onderwijsniveau van allochtone leerlingen - weer kunnen veranderen.

Er zijn wel gegevens bekend over het percentage 'achterstandsleerlingen' op de diverse scholen in Slotervaart. Dit zijn leerlingen van wie op grond van een aantal kenmerken wordt verondersteld dat zij extra aandacht nodig hebben om het onderwijs te kunnen volgen. In het schooljaar 2002/2003 behoorde 49 procent van alle Amsterdamse basisschoolleerlingen tot deze categorie (een zogenaamd leerlinggewicht van 1,9), bijna vier maal zoveel als landelijk gemiddeld (13\%). Op sommige scholen in Overtoomse Veld, zoals de islamitische El Kadisiaschool en aanpalende buurten, zoals de openbare Einsteinschool, bestaat vrijwel het gehele leerlingenbestand uit '1,9-leerlingen'. ${ }^{12}$ Toch tellen niet alle basisscholen zoveel achterstandsleerlingen. Scholen in buurten waar meer autochtonen wonen (met name de buurt Nieuw Sloten) is het aandeel achterstandsleerlingen aanzienlijk geringer.

In tabel 3.7 zijn de basisscholen in het stadsdeel Slotervaart ingedeeld volgens zogenaamde 'schoolscoregroepen'. Op grond van de leerlinggewichten worden scholen in zeven categorieën ingedeeld, variërend van scholen met geen achterstandsleerlingen (schoolscoregroep 1) tot scholen met meer dan 75 procent achterstandsleerlingen (schoolscoregroep 7). Van de twaalf basisscholen in Slotervaart behoren er vier tot deze categorie met de meeste achterstandsleerlingen. Tien van de twaalf basisscholen (83\%) in het stadsdeel behoren tot de schoolscoregroepen $5 / 6 / 7$. Voor deze scholen geldt dat een (ruime) meerderheid van de kinderen tot de achterstandsleerlingen behoort. In heel Amsterdam behoort drie kwart van alle basisscholen tot de schoolscoregroepen 5/6/7, in heel Nederland is dat bij 18 procent van alle basisscholen het geval. ${ }^{13}$ Deze schoolscoregroepen zijn vooral belangrijk om een beeld te vormen over de onderwijsresultaten van scholen. Het ligt voor de hand dat de onderwijsresultaten op scholen met veel achterstandsleerlingen minder zijn dan op scholen met weinig van zulke leerlingen. 


\section{Onderwijsresultaten}

In Amsterdam zijn gedetailleerde gegevens beschikbaar over de zogenaamde Cito-scores van scholen. Deze gegevens zijn gebaseerd op de resultaten van de Cito-toets, die aan het einde van de basisschool wordt afgenomen. Door de resultaten van alle leerlingen en scholen bij elkaar op te tellen, kunnen per school of stadsdeel gemiddelde Cito-scores berekend worden.

Tabel 3.6 Gemiddelde Cito-scores in Nederland, Amsterdam en het stadsdeel Slotervaart (1999-2004)

\begin{tabular}{|l|r|r|r|r|r|r|} 
& $\mathbf{1 9 9 9}$ & $\mathbf{2 0 0 0}$ & $\mathbf{2 0 0 1}$ & $\mathbf{2 0 0 2}$ & $\mathbf{2 0 0 3}$ & $\mathbf{2 0 0 4}$ \\
Stadsdeel Slotervaart & & & & & & \\
Gemeente Amsterdam & 530,6 & 531,4 & 532,7 & 533,2 & 532,3 & 534,0 \\
Nederland & 531,7 & 531,8 & 533,3 & 533,3 & 533,1 & 535,7 \\
Verschil Nl-Adam & 534,2 & 534,0 & 534,9 & 534,8 & 534,7 & 535,9 \\
& 2,5 & 2,2 & 1,6 & 1,5 & 1,6 & 0,2 \\
\hline
\end{tabular}

Bron: O\&S en DMO, Cito-scores in Amsterdam 2004

Tabel 3.6 laat zien dat de gemiddelde Cito-scores in zowel Amsterdam als in het stadsdeel Slotervaart tussen 1999 en 2003 meer zijn gestegen dan landelijk gemiddeld. Ondanks het hoge aandeel (potentiële) achterstandskinderen zijn de onderwijsresultaten in Amsterdam dus gemiddeld niet zoveel slechter dan elders in het land. De cijfers uit 2004 zijn op een andere manier berekend en kunnen daarom niet vergeleken worden met gegevens uit eerdere jaren. ${ }^{14}$ Door de nieuwe berekening van de Cito-scores is het verschil tussen de gemiddelde Cito-score in Amsterdam en in heel Nederland nog slechts minimaal $(535,7$ versus 535,9$)$. De gemiddelde Cito-score van alle basisscholen in het stadsdeel Slotervaart ligt nog wel beduidend lager dan zowel het Amsterdamse als het landelijke gemiddelde $(534,0)$. Tabel 3.7 laat de gemiddelde Cito-scores van de afzonderlijke basisscholen in het stadsdeel Slotervaart zien. De scholen zijn ingedeeld in de al genoemde schoolscoregroepen, zodat de onderwijsresultaten per school kunnen worden afgezet tegen de gemiddelde scores van scholen met vergelijkbare leerlingenpopulatie. In de tabel kan ook worden afgelezen in welke buurten in Slotervaart de scholen gesitueerd zijn.

De eerste conclusie die uit de tabel kan worden getrokken is dat Amsterdamse scholen in bijna alle schoolscoregroepen het beter doen dan vergelijkbare scholen in de rest van Nederland (alleen bij schoolscoregroep 4 is dit niet het geval).

Kennelijk zijn basisscholen in Amsterdam in staat iets betere onderwijsresultaten te boeken met achterstandsleerlingen dan landelijk gemiddeld. Als we vervolgens naar de gemiddelde Cito-scores per school kijken, dan valt in de tweede plaats op dat de onderwijsresultaten niet altijd samenhangen met het aandeel achterstandskinderen op school. Twee scholen met relatief veel achterstandskinderen springen eruit, omdat de Cito-score beduidend hoger ligt dan gemiddeld bij qua sociale achtergrond vergelijkbare scholen in zowel Amsterdam als heel Neder- 
Tabel 3.7 Gemiddelde Cito-score in Nederland, Amsterdam en (scholen in) Slotervaart (2004)

\begin{tabular}{|c|c|c|c|c|c|}
\hline ssg & $\begin{array}{l}\text { Neder- } \\
\text { land }\end{array}$ & $\begin{array}{l}\text { Amster- } \\
\text { dam }\end{array}$ & $\begin{array}{l}\text { Basisscholen in } \\
\text { Slotervaart }\end{array}$ & $\begin{array}{l}\text { Gem. } \\
\text { Cito-score }\end{array}$ & Buurt \\
\hline 1 & 538,4 & 542,2 & - & & \\
\hline 2 & 537,0 & 540,7 & De Zevensprong & 536,5 & Nieuw Sloten \\
\hline 3 & 535,8 & 537,8 & De Mijlpaal & 535,2 & Nieuw Sloten \\
\hline 4 & 533,9 & 532,0 & - & & \\
\hline \multirow[t]{3}{*}{5} & 534,1 & 536,4 & De Vlaamse Reus & 538,0 & Nieuw Sloten \\
\hline & & & Pro Rege & 538,6 & Oostoever/Hemsterhuis \\
\hline & & & 7e Montessorischool & 539,0 & Overtoomse Veld \\
\hline \multirow[t]{3}{*}{6} & 531,8 & 533,6 & Louis Bouwmeester & 529,3 & Slotervaart midden \\
\hline & & & Bisschop Huibers & 532,9 & Oostoever/Hemsterhuis \\
\hline & & & Sint Jan de Doper & 537,3 & Delflandplein/Staalmanplein \\
\hline \multirow[t]{4}{*}{7} & 530,3 & 531,9 & Prof Einstein & 525,3 & Delflandplein/Staalmanplein \\
\hline & & & Ru Paré & 525,3 & Overtoomse Veld \\
\hline & & & El Kadisia & 530,5 & Overtoomse Veld \\
\hline & & & Prof Johan Huizinga & 533,4 & Oostoever/Hemsterhuis \\
\hline
\end{tabular}

Gegevens: DMO, Cito-scores in Amsterdam 2004 (bijlage A: Cito-scores per stadsdeel 2004)

land. Dit zijn de katholieke Sint Jan de Doperschool en de openbare Johan Huizingaschool. Ook mag worden opgemerkt dat de islamitische El Kadisiaschool met maar liefst 97 procent achterstandsleerlingen ('1,9-leerlingen') het verhoudingsgewijs niet slechter doet dan andere scholen met zeer veel achterstandsleerlingen in Nederland.

\section{Schooluitval}

Voortijdige schooluitval vormt een belangrijke oorzaak van het lage scholingsniveau van veel allochtone jongeren. Volgens recente cijfers heeft 21 procent van alle Turkse en 17 procent van alle Marokkaanse jongeren en jongvolwassenen (van 15 tot 34 jaar) in Nederland hun voortgezette opleiding in Nederland zonder diploma verlaten. In 1998 lag het aantal voortijdige schoolverlaters onder Turkse en Marokkaanse jongeren en jongvolwassenen overigens nog beduidend hoger (resp. 27 en 22\%) (Dagevos 2003: 125; Groeneveld en Weijers-Martens 2003: 40). Voortijdige schooluitval komt vooral vaak voor in de lagere regionen van het beroepsonderwijs (vmbo, roc's). Voortijdige schooluitval gaat niet alleen de betreffende leerlingen en scholen aan, maar ook de gemeente.

De gemeente (stadsdeel) heeft enerzijds een wettelijke taak in de handhaving en uitvoering van de leerplichtwet (voor jongeren van 5 tot 17 jaar) en wil anderzijds stimuleren dat ook wat oudere jongeren een minimale startkwalificatie halen. Een minimale startkwalificatie is (volgens Europese normen!) een diploma op minimaal het niveau van havo/vwo of mbo niveau 2. De overheid kan niet garanderen dat iedereen een minimale startkwalificatie haalt, omdat niet iedereen over 
de benodigde cognitieve mogelijkheden beschikt. Het stadsdeel Slotervaart ziet echter wel een inspanningsverplichting om jongeren tot 23 jaar te begeleiden tot ze een minimale startkwalificatie hebben behaald. ${ }^{15}$ Het gaat hier overigens om een wettelijke taak ingevolge de RMC-wet.

Sinds midden jaren negentig speelt de gemeente een centrale rol bij de handhaving van de leerplicht en het terugdringen van voortijdige schooluitval. Anders dan in veel andere gemeenten weet men in Amsterdam vrij nauwkeurig hoeveel en welke jongeren niet meer op school zitten en ook geen minimale startkwalificatie hebben behaald. Op het moment van schrijven van deze rapportage had men dat uitgezocht voor alle 17-jarigen in Amsterdam, maar de bedoeling is dat men dit uiteindelijk voor alle jongeren tot 23 jaar uitzoekt. Figuur 3.2 laat zien dat 13 procent van alle Amsterdamse 17-jarigen zonder minimale startkwalificatie van school is gegaan. In het stadsdeel Slotervaart ligt het aandeel voortijdige schoolverlaters iets lager dan gemiddeld in de stad (11 procent).

\section{Figuur 3.2 Percentage 17-jarigen zonder minimale startkwalificatie}

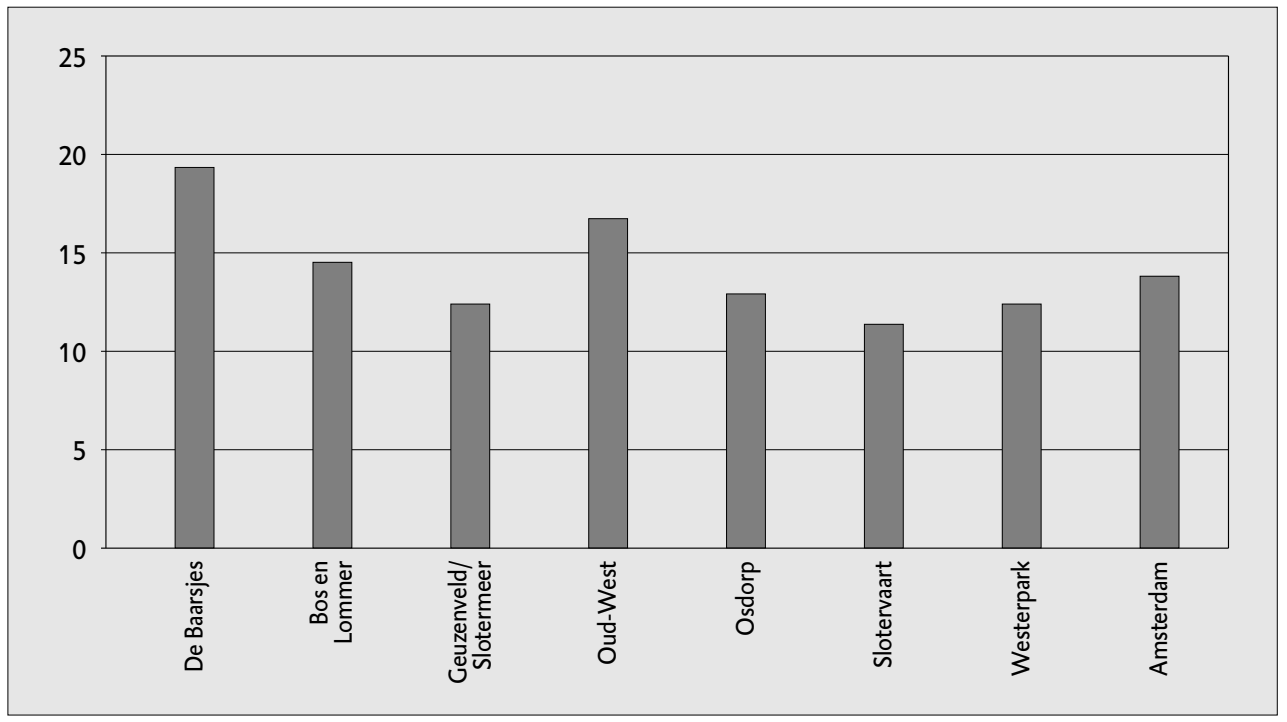

Bron: RMC, stadsdeel Slotervaart

\subsubsection{WERKLOOSHEID EN UITKERINGSAFHANKELIJKHEID}

Een laatste, maar zeker niet het minst belangrijke probleem in buurten als Overtoomse Veld is de problematiek van werkloosheid, uitkeringsafhankelijkheid en armoede.

Gegevens over deze onderwerpen laten overigens zien dat het stadsdeel Slotervaart zeker niet als een homogene achterstandswijk mag worden beschouwd. Naast meer problematische buurten zoals Overtoomse Veld en Westlandgracht met verhoudingsgewijs veel werklozen en uitkeringsgerechtigden kent het stads- 
deel ook 'betere buurten', zoals met name de nieuwbouwwijk Sloter- en Riekerpolder. In deze buurt zijn de werkloosheid en uitkeringsdichtheid uitgesproken laag. Als gevolg daarvan ligt het aandeel werklozen en uitkeringsgerechtigden in het hele stadsdeel Slotervaart ook lager dan gemiddeld in de stad. Als we het hele stadsdeel overzien, kan zeker niet van een achterstandswijk gesproken worden. Dit geldt echter wel voor buurten als Overtoomse Veld.

Tabel 3.8 Werk, werkloosheid en uitkeringsafhankelijkheid in Amsterdam en het stadsdeel Slotervaart (2003)

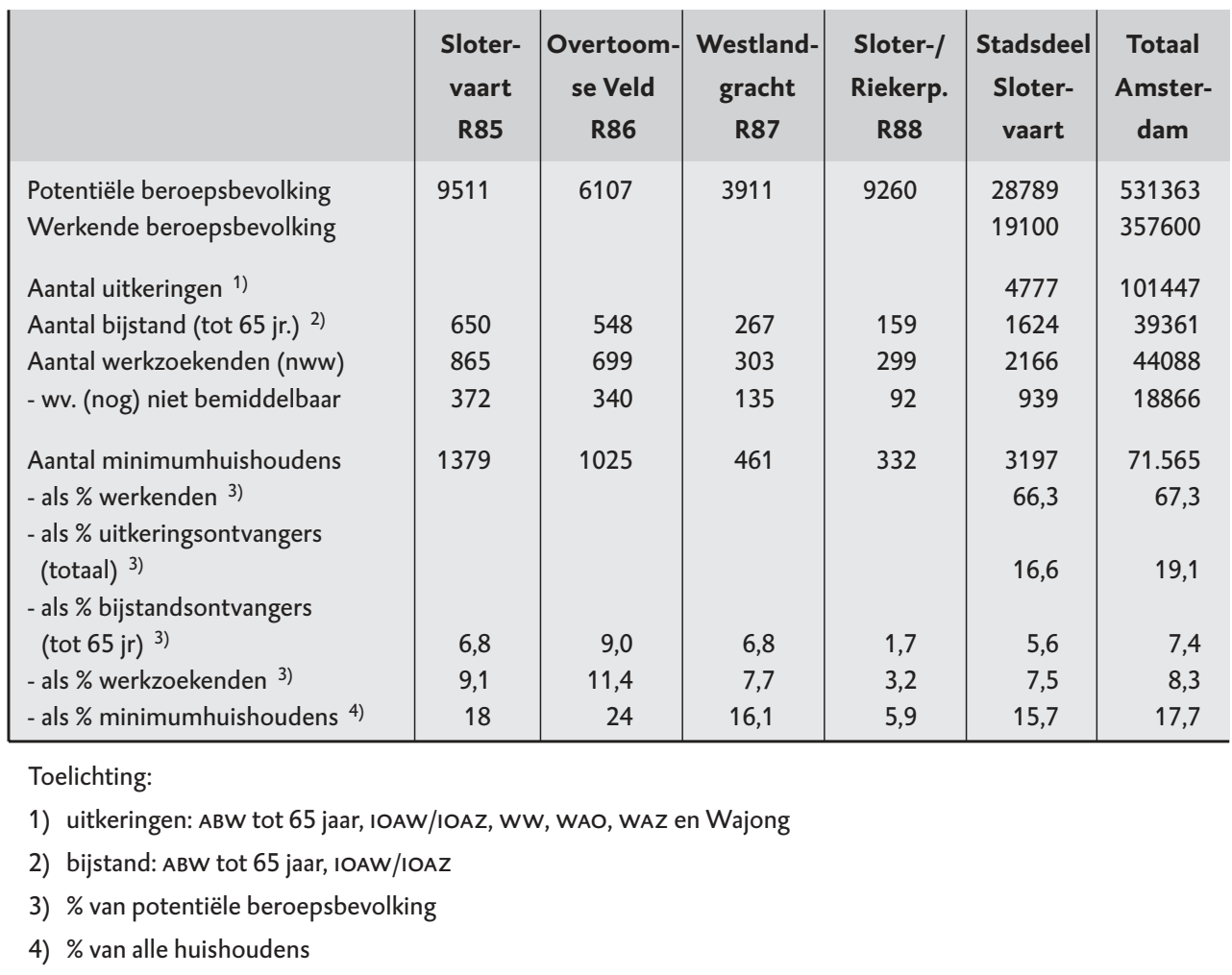

\section{Bron: Gemeente Amsterdam, Dienst O\&S}

Opmerkelijk is dat het aandeel werkenden (ook wel netto-arbeidsparticipatie genoemd), evenals het aandeel werkzoekenden, in het stadsdeel Slotervaart op vergelijkbaar niveau ligt als het stedelijk gemiddelde. In de buurt Overtoomse Veld liggen het aandeel werkzoekenden bij bijstandsgerechtigden echter beduidend hoger dan gemiddeld in de stad. Overtoomse Veld kent relatief veel bijstandsgerechtigden ( $9 \%$ van de totale bevolking in de werkzame leeftijd heeft een bijstandsuitkering) en werkzoekenden (ruim 11\% van de bevolking in de werkzame leeftijd). Vooral het aantal minimumhuishoudens in Overtoomse Veld ligt erg hoog. Maar liefst een op de vier huishoudens in de buurt moet rondkomen van een inkomen onder of rond het sociaal minimum. 


\subsection{DISCUSSIE}

De naoorlogse wijken in Amsterdam-West worden de laatste jaren steeds vaker een van de meest problematische delen van de stad genoemd. Het idee dat sociale problemen vooral voorkomen in de oude wijken van de stad is in Amsterdam al sinds jaren achterhaald. De oude binnenstad van Amsterdam is geliefd bij de nieuwe stedelijke elite, terwijl de minder draagkrachtigen - onder wie allochtone huishoudens - in toenemende mate aangewezen zijn op goedkope, naoorlogse woningen buiten de Amsterdamse ring (A10). Toch is een stadsdeel als Slotervaart zeker geen homogene achterstandswijk. Naast 'slechte' buurten als Overtoomse Veld en Westlandgracht met veel werklozen, bijstandsontvangers en arme huishoudens kent het stadsdeel ook uitgesproken 'goede' buurten, zoals de nieuwbouwwijk Nieuw Sloten.

Het meest evidente probleem van het stadsdeel Slotervaart is zonder meer de zeer hoge criminaliteit. Afgaande op criminaliteitscijfers van de politie ligt het aantal delicten per duizend inwoners in buurten Overtoomse Veld en Westlandgracht nog hoger dan het toch al zeer hoge stedelijk gemiddelde in Amsterdam en zeker veel hoger dan elders in Nederland (ook beduidend hoger dan in Rotterdam). Veel delicten zijn het werk van Marokkaanse jongeren en jongerengroepen die op straat rondhangen. De problematiek van Marokkaanse jongeren in Overtoomse Veld kreeg landelijke bekendheid door de rellen van 1998. Voor de politie en andere lokale autoriteiten waren deze rellen echter aanleiding om de problematiek in de wijk harder en gerichter aan te pakken. Deze aanpak van problemen, die hierna wordt besproken, was in zoverre succesvol dat de criminaliteitscijfers in Overtoomse Veld - hoewel ze nog steeds zeer hoog zijn - de afgelopen jaren wel wat zijn gedaald. Ook bij de door bewoners ervaren veiligheid in de buurt ('subjectieve veiligheid') lijkt sprake van enige verbetering, hoewel de situatie nog lang niet terug is op het niveau van midden jaren negentig.

Verreweg de meeste gepleegde delicten in Overtoomse Veld vallen in de categorie 'veiligheidsdelicten' zoals diefstal en inbraak woning, diefstal van en uit auto's, zakkenrollerij, maar ook geweldsdelicten zoals geweld tegen persoon, bedreiging, mishandeling, straatroof en overvallen. In 2002 werden in totaal 128 van zulke veiligheidsdelicten per duizend inwoners van Overtoomse Veld geregistreerd. Concreet betekent dit dat gemiddeld één op de acht inwoners van de buurt te maken had met zo'n delict. Dit is, hoewel minder dan in de jaren daarvoor, nog altijd erg veel.

Naast criminaliteitsbestrijding is stedelijke vernieuwing een tweede prioriteit in het gevoerde stedelijk beleid. De gemeente Amsterdam beoogt door stedelijke vernieuwing tot een meer gevarieerde woningvoorraad, tot een betere leefomgeving, maar ook tot meer woningen te komen. In heel Amsterdam moeten er de komende decennia 90 duizend woningen bijkomen, in de Westelijke Tuinsteden (waaronder het stadsdeel Slotervaart) moet het aantal woningen met 11 duizend toenemen ('verdichting'). Op deze wijze probeert men wat te doen aan het 
woningtekort en de al sinds jaren overspannen woningmarkt in de hoofdstad. Tegelijk worden veel goedkope en kwalitatief minder goede woningen gesloopt. In de Westelijke Tuinsteden gaat zelfs een derde van de totale goedkope woningvoorraad tegen de vlakte. Hoewel er ook goedkope nieuwbouw is gepland, zal de totale goedkope woningvoorraad in dit deel van Amsterdam met ongeveer een derde verminderen.

Het stadsdeelbestuur van de Slotervaart heeft echter de garantie gegeven dat iedereen die na de verbouwing van de buurt wil terugkeren dat ook mag. De vraag is echter of de huidige bewoners de duurder wordende woningen in de wijk - ondanks toegezegde maatregelen zoals een huurgewenningsregeling - wel kunnen betalen. In ieder geval bestaat er een spanning tussen enerzijds het inkrimpen van de goedkope woningvoorraad in het stadsdeel Slotervaart en anderzijds het grote aantal bewoners uit de wijk dat is aangewezen op een goedkope woning.

Een ander groot probleem van de voorgenomen stedelijke vernieuwing is dat het proces zolang duurt. De eerste vernieuwingsplannen stammen al uit het midden van de jaren negentig, maar tot dusver is er - door allerlei bureaucratische verwikkelingen - concreet nog maar weinig gebeurd. De steeds weer uitgestelde vernieuwing heeft echter onbedoelde gevolgen. Zo ontstond er onder bewoners grote onzekerheid over wat er met hun woning gebeurt en of ze nog wel in de buurt kunnen terugkeren. Woningeigenaren stopten met het oog op de aangekondigde sloopplannen met woningonderhoud, waardoor de toch al vaak slechte woningen in Overtoomse Veld nog sneller in verval zijn geraakt.

Onderwijssegregatie is een ander gevolg van de opkomst van multiculturele buurten als Overtoomse Veld. Het ontstaan van 'zwarte' scholen wordt om meerdere redenen ongewenst geacht. Ten eerste komen allochtone kinderen op zwarte scholen niet of nauwelijks meer in contact met autochtone kinderen. Ten tweede zou de concentratie van allochtone kinderen (onder wie veel achterstandsleerlingen) op bepaalde scholen tot (nog) slechtere schoolresultaten leiden. Het uiteindelijke gevolg daarvan zou kunnen zijn dat sociale achterstand door de tekortschietende schoolprestaties van allochtone kinderen van de ene generatie wordt overgedragen aan de andere.

De in dit hoofdstuk gepresenteerde gegevens over onderwijsresultaten (gemiddelde Cito-scores) van Amsterdamse basisscholen laten echter zien dat dit laatste niet per definitie het geval is. Uiteraard boeken scholen met veel (potentiële) achterstandsleerlingen minder resultaten dan scholen met minder van zulke leerlingen. Des te opvallender is het dat de gemiddelde Cito-score van alle Amsterdamse basisscholen (waarvan bijna de helft van het leerlingenbestand uit achterstandsleerlingen bestaat) nog nauwelijks afwijkt van het landelijk gemiddelde. Amsterdamse scholen met veel achterstandsleerlingen doen het over het algemeen beter dan vergelijkbare scholen elders in Nederland. Kennelijk heeft men geleerd redelijke onderwijsresultaten te boeken mét achterstandsleerlingen. Van de basisscholen in de buurt Overtoomse Veld sprongen er twee uit. De bijna 
volledig 'zwarte' Johan Huizingaschool boekte beduidend betere resultaten dan het landelijke én stedelijke gemiddelde van scholen met veel achterstandsleerlingen. Vermeldenswaard is ook dat de (eveneens vrijwel volledig 'zwarte') islamitische basisschool El Kadisia het verhoudingsgewijs niet slechter doet dan scholen met veel achterstandsleerlingen elders in Nederland.

Multiculturele achterstandsbuurten als Overtoomse Veld worden ten slotte gekenmerkt door hoge aantallen werklozen, uitkeringsgerechtigden en arme huishoudens. Ongeveer een op de tien volwassenen in Overtoomse Veld (tussen 15 en 64 jaar) is werkloos, eveneens ongeveer een op de tien volwassen bewoners leeft van een bijstandsuitkering en maar liefst een op de vier huishoudens moet rondkomen van een inkomen onder of rond het sociaal minimum. Hiermee ligt het aantal minimumhuishoudens in de buurt meer dan 2,5 maal zo hoog als landelijk gemiddeld. 


\section{NOTEN}

1 Scheffer, P., Integratie kun je bouwen. In: NRC Handelsblad, d.d. 26 juni 2004.

2 Deze paragraaf is in belangrijke mate gebaseerd op het rapport van E. van

Kempen i.s.m. S. Kamp (2003), Neighbourhood Governance Capacity for Social Integration. The Dutch case study: Overtoomse veld. Amsterdam: Department of Geography and Planning.

3 Resp. A8 (Resp. verwijst naar de lijst respondenten in Bijlage 1, p. 123): Buurtregisseur, Politie Amsterdam-Amstelland.

4 Geciteerd in SEC tijdschrift over samenleving en criminaliteitspreventie, april 2001.

5 Jeugdveiligheidsplan district 6 (2003-2006), d.d. 28 november 2002. Het politiedistrict 6 omvat de vier stadsdelen in Amsterdam-West: Slotervaart, Osdorp, De Baarsjes en Geuzenveld-Slotermeer.

6 Persbericht Gemeente Amsterdam, Amsterdam wordt veiliger, d.d. 25-6-2004.

7 Amsterdams wonen na morgen - Een ambtelijk essay over de toekomst van het wonen. SwD katern.

8 Resp. A11: Procesmanager Stedelijke Vernieuwing in het stadsdeel Slotervaart.

9 Informatiekrant Stedelijk Vernieuwing.

10 Dit hele proces is uitvoerig beschreven door Van Kempen (2003).

11 Stadsdeelbestuur Slotervaart, Leren in een breed verband. Lokaal onderwijsplan 2002-2006 Slotervaart/ Overtoomse Veld (vastgesteld februari 2002).

12 Gegevens: O\&S, De staat van de stad 2003, p. 55; Stadsdeel Slotervaart, Lokaal onderwijsplan 2002-2006.

13 Gegevens: DMO, Citoscores in Amsterdam 2004 (juli 2004).

14 In 2004 worden de schoolresultaten van leerlingen die praktijkonderwijs of leerweg ondersteunend onderwijs gaan volgen - in praktijk de zwakste leerlingen van de basisscholen - niet meer meegerekend bij de gemiddelde scores per school en per stadsdeel.

15 Interview Resp. A4: lid van dagelijks bestuur van het stadsdeel Slotervaart, portefeuille: Onderwijs, Welzijn, Buurtbeheer, Werk, Burgerzaken, Personeelszaken. 


\section{ONDERZOEKSBUURT DE TARWEWIJK}

\subsection{DE BUURT: ACHTERGROND EN BEWONERS}

De Rotterdamse deelgemeente Charlois is de afgelopen tijd veelvuldig op negatieve wijze in het nieuws geweest. Een van de buurten in deze deelgemeente, de Millinxbuurt, kreeg landelijke bekendheid als een van de meest problematische stadsbuurten van Nederland. Enkele decennia geleden was de Millinxbuurt nog een nette middenklassebuurt 'op zuid'. Eind jaren zeventig begint echter de trek van de meer welgestelde bewoners van de Millinxbuurt naar de randgemeenten rond de stad, een proces dat nog wordt versneld door de aanleg van de metro dwars door de buurt (Desmet et al. 2003). De buurt begint te verpauperen, het aantal verhuizingen neemt toe, evenals de leegstand en de buurt komt in een neerwaartse spiraal terecht. In de jaren tachtig wordt een renovatieplan voor de buurt afgeblazen, mede omdat eigenaren het te veel risico vinden om in de buurt te investeren. Er komen zogenaamde huisjesmelkers, die hun woningen voor veel geld verhuren. Als gevolg van dit alles wordt de buurt min of meer overgenomen door junks, drugshandelaren en kleine criminelen.

De geschiedenis van de Millinxbuurt is echter ook een 'verhaal van verzet en hoop' genoemd. Op een gegeven moment komen de bewoners in opstand tegen het verval van de buurt, en de gemeente en politie besluiten tot actie over te gaan. De buurt wordt overhoopgehaald, drugspanden worden gesloten en tal van dealers werden opgepakt. De fouilleringsactie eind $1999 \mathrm{krijgt}$ veel aandacht in de media (vgl. HP/De Tijd 2003: 19 sept; СОT 2000).

De Millinxbuurt (slechts acht straten groot) maakt deel uit van de Tarwewijk, een wijk die op haar beurt samen met acht andere wijken ${ }^{1}$ deel uitmaakt van de deelgemeente Charlois. De Tarwewijk telt zo'n 12 duizend inwoners, waarvan twee derde tot de etnische minderheden gerekend kan worden (tabel 4.1). In heel Charlois behoort momenteel 44 procent van de inwoners tot een etnische minderheid. De verwachting is echter dat het minderhedenaandeel onder de bevolking van Charlois in 2017 zal zijn opgelopen tot zo'n 75 procent. De Tarwewijk en dan met name de Millinxbuurt heeft een aantrekkingskracht op mensen uit het Caribische gebied. Zo wonen er in de Tarwewijk relatief 3 keer zoveel Antillianen als in heel Rotterdam.

Het aantal Antillianen in de Tarwewijk is bovendien in 5 jaar met bijna 42 procent toegenomen ( $\operatorname{van} 897$ Antillianen in 1999 naar 1271 in 2004²). Opvallend is verder de groene bevolkingssamenstelling van de Tarwewijk; er is een relatief groot aandeel jongeren (tot 35 jaar) en een klein aandeel ouderen (55 plus).

De Tarwewijk is in de jaren twintig en dertig van de vorige eeuw gebouwd voor de arbeiders die werkzaam waren in de haven en de opkomende petroleumbedrijven. De Rotterdamse haven en aanverwante bedrijven trokken veel arbeiders aan van buiten de regio, waardoor zich veel Brabanders, Zeeuwen en Groningers in 


\begin{tabular}{|l|r|r|r|} 
& Tarwewijk & Charlois & Rotterdam \\
Bevolking naar leeftijdsgroepen & & & \\
Totaal aantal inwoners & 12018 & 66684 & 599544 \\
wv. 0 t/m 34 jaar (in \%) & 60,3 & 51,1 & 48,1 \\
$35 \mathrm{t} / \mathrm{m}$ 54 jaar (in \%) & 26,5 & 25,3 & 27,7 \\
55 jaar en ouder (in \%) & 13,2 & 23,5 & 24,3 \\
Bevolking naar etnische groepen (in \%) & & & \\
wv. Nederlanders & 28,4 & 48 & 54,8 \\
Zuid-Europeanen & 3,1 & 3,7 & 3,1 \\
Overig west. landen & 3,5 & 4,4 & 5,7 \\
Surinamers & 13,7 & 9,6 & 8,8 \\
Antillianen & 10,6 & 7 & 3,4 \\
Kaapverdianen & 2,5 & 1,7 & 2,5 \\
Turken & 12,7 & 7,5 & 7,5 \\
Marokkanen & 7,8 & 5,9 & 5,9 \\
Overig niet-west. landen & 17,7 & 12,3 & 8,4 \\
Totaal minderheden* in 2003 & 65,0 & 44,0 & 36,5 \\
Verwacht aandeel minderheden* in 2017 & $n . b$. & 75,8 & 48,0 \\
\hline
\end{tabular}

Toelichting:

* Minderheden = Surinamers, Antillianen/Arubanen, Kaapverdianen, Turken, Marokkanen en overig arm. Naar geboorteland van de persoon zelf of diens vader of moeder.

Bron: Gemeente Rotterdam, cos

Charlois vestigden. ${ }^{3}$ Men treft in de Tarwewijk veel portiekwoningen van drie of vier woonlagen, waarvan de bewoners het trappenhuis delen. Het woningaanbod in de buurt wordt tegenwoordig als onaantrekkelijk beschouwd, aangezien de woningen klein en vaak slecht onderhouden zijn. Kenmerkend voor de buurt is verder dat er veel particuliere huurwoningen zijn (tabel 4.2). Rond 1990 waren de particuliere woningen veelal nog eigendom van grote eigenaren en beleggers, maar mede vanwege de oplopende onderhoudskosten verkochten zij hun eigendom op grote schaal aan kleine beleggers die minder rendementseisen stellen. Vandaar dat je de ouderwetse huisbaas (iemand die een klein aantal panden bezit en deze met winstoogmerk verhuurt) hier nog volop aantreft. Een steeds groter deel van de huisbazen zijn speculanten en huisjesmelkers (Aalbers 2004).

Wanneer we naar de kenmerken van de woningvoorraad in de Tarwewijk en heel Charlois kijken, dan vallen drie dingen op: ten eerste het grote aandeel woningen in particulier bezit ( $43 \%$ van de totale woningvoorraad), ten tweede de aanzienlijke leegstand en ten derde het grote aandeel bewoners dat binnen één jaar weer 
verhuisd is. Dit laatste cijfer geldt algemeen als een indicator dat bewoners ontevreden met hun buurt zijn. Weliswaar woont nog altijd 43 procent van de bewoners van de Tarwewijk vijf jaar of langer in de buurt, maar begin jaren negentig lag het aandeel bewoners dat zo lang in de buurt woont nog beduidend hoger (48\%, gegevens niet in de tabel 4.2 ).

Tabel 4.2 Kenmerken van de woningvoorraad in Tarwewijk, Charlois en Rotterdam (2003)

\begin{tabular}{|l|c|c|c|} 
& Tarwewijk & Charlois & Rotterdam \\
Eigendom woningen (in \%) & & & \\
Koopwoningen & 21 & 21 & 23 \\
Particulieren & 43 & 28 & 21 \\
Gemeente/corporatie & 35 & 50 & 55 \\
Bezetting woningen (in \%) & & & \\
Passend & 70 & 77 & 75 \\
Onderbezet & 9 & 11 & 15 \\
Overbezet & 3 & 2 & 0 \\
Sterk overbezet & 1 & 0 & 8 \\
Administratief leeg & 17 & 10 & 19 \\
Verblijfsduur op adres (in \%) & & & 22,5 \\
(minder dan) 1 jaar & 28,7 & 23,2 & 58,5 \\
Tussen de 2 en 4 jaar & 28,4 & 25,2 & \\
(meer dan) 5 jaar & 43 & 51,5 & \\
\hline
\end{tabular}

Bron: Gemeente Rotterdam, cos

De impopulaire Tarwewijk met haar lage huren, veel leegstand en vele particuliere verhuurders bleek een aantrekkelijke vestigingsplaats voor de lokale onderwereld. In de loop van de jaren negentig komt een steeds groter aantal woningen in handen van drugsgebruikers en dealers, overigens mede omdat zij elders in de stad werden weggejaagd en Perron Nul in 1994 gesloten werd. Later vestigen zich ook steeds meer illegalen en andere 'kansarme' migranten in de Tarwewijk en elders in de deelgemeente Charlois. Dominic Schrijer, dagelijks bestuurder van de deelgemeente, stelt over de vele kansarme bewoners in Charlois:

"Door de weinig perspectiefrijke omstandigheden waarin deze mensen zich bevinden, zijn zij aangewezen op de hulp van lotgenoten, maar ook op mensen die hun situatie uitbuiten (huisjesmelkers, illegaal werk zoals drugshandel en prostitutie). Voor andere mensen in deze wijken veroorzaken deze mensen niet zelden - bewust of onbewust - veel overlast" (Schrijer 2003). 
Volgens Schrijer is de achteruitgang van de deelgemeente Charlois heel snel gegaan en zijn de problemen in de Tarwewijk het meest pregnant:

"Charlois is begin jaren negentig altijd de meest gemiddelde deelgemeente van Rotterdam geweest. Het had stadsvernieuwing, je had wat probleembuurtjes, je had een naoorlogse wijk waar het goed mee ging, maar je had ook het Zuidplein, Ahoy en grootstedelijk voorzieningen. Begin jaren zeventig was Charlois af, het was klaar. Maar in de loop van de jaren negentig bleek dat we niet meer bij de middenmoot van de lijstjes van Rotterdam hoorden, dat we afzakten naar het niveau van Delfshaven, Feijenoord. Pendrecht is het beste voorbeeld van de achteruitgang: Pendrecht was in Charlois de wijk die qua onderwijsscores, opleidingsniveau, werkgelegenheidscijfers, veiligheid en vastgoedwaarde altijd bovenaan stond. En in tien jaar tijd zijn ze afgezakt naar de op een na laagste plaats. Alleen de Tarwewijk scoort slechter dan Pendrecht” (Resp. R8)4.

\subsection{DE BELANGRIJKSTE PROBLEMEN IN DE BUURT}

In Rotterdam werd de stedelijke problematiek vanouds meestal gedefinieerd in termen van armoede, werkloosheid en sociale achterstand. In de hedendaagse Rotterdamse discussie en zeker in buurten als de Tarwewijk liggen de meest evidente problemen op het gebied van veiligheid, leefbaarheid en volkshuisvesting. Het accent in onze probleembeschrijving ligt dan ook met name op deze terreinen.

\subsubsection{LEEFBARHEID EN VEILIGHEID IN DE BUURT}

Veiligheid wordt volgens Schrijer, dagelijks bestuurder van de deelgemeente Charlois, gezien als primaire voorwaarde om een wijk of buurt te kunnen verbeteren.

“Als een buurt niet veilig is, als een buurt volledig gedomineerd wordt door de Antilliaanse, Marokkaanse, Turkse drugsmaffia, dan slaan initiatieven als Opzoomeren, sociaal investeren, moeders naar taalles sturen, leuke dingen met kinderen doen nergens op. Je moet eerst zorgen dat er een basisniveau van veiligheid en leefbaarheid is. Als overheid moet je dat kunnen garanderen voordat je naar bewoners toegaat om te zeggen dat ze hun woning moeten opknappen. Want zo'n bewoner zegt dan terecht: 'Ik mijn woning opknappen? Sodemieter op! Zorg jij maar dat je de boel hier op orde hebt, en als jij het veilig hebt, ga ik wel investeren in mijn woning.' Want zo'n man krijgt een investering in een onveilige buurt nooit terug. Sterker nog, hij krijgt geeneens een hypotheek of lening. Ondernemers en bouwbedrijven zeggen: 'Wij gaan hier niet werken, want alles wordt onder onze konten gejat. We gaan hier alleen werken als er's nachts bewaking is'” (Resp. R8).

In Rotterdam wordt de veiligheid in de stad jaarlijks gemeten aan de hand van een veiligheidsindex. Deze index bestaat uit zowel objectieve indicatoren, afkomstig uit gegevens van politie, justitie en gemeentelijk diensten, als subjectieve indicatoren, verkregen uit een enquête over veiligheid die is afgenomen onder bewoners. 
Uit al deze gegevens krijgen wijken een cijfer toegekend variërend tussen de nul en tien, waarvoor geldt: hoe hoger het cijfer, des te veiliger is de wijk. Over Charlois werd geconcludeerd dat het zich in 2003 in de zogenaamde 'bedreigde zone' bevindt (zie tabel 4.3). Binnen Charlois scoort de Tarwewijk met een cijfer van slechts 3.5 het laagst op de veiligheidsindex. De Tarwewijk wordt dan ook als een 'onveilige wijk' geclassificeerd en is de op drie na onveiligste wijk van heel Rotterdam. ${ }^{5}$ Wanneer wij dit cijfer van de Tarwewijk afzetten tegen het Rotterdamse gemiddelde $(6,2 \%)$, dan zien we dat de Tarwewijk met een groot veiligheidsprobleem heeft te kampen. Verder valt op dat de veiligheidssituatie in zowel heel Rotterdam en in de deelgemeente Charlois tussen 2001 en 2003 enigszins is verbeterd, maar dat dit niet geldt voor de Tarwewijk.

Tabel 4.3 Veiligheidsindex 2001-20036

\begin{tabular}{|c|c|c|c|c|}
\hline & $\begin{array}{c}\text { Positionering } \\
2003\end{array}$ & 2001 & 2002 & 2003 \\
\hline \multicolumn{5}{|l|}{ Wijk } \\
\hline Tarwewijk & Onveilig & 3.6 & 3.5 & 3.5 \\
\hline Zuidplein & Onveilig & 2.9 & 2.7 & 3.7 \\
\hline Pendrecht & Probleem & 4 & 3.9 & 4.3 \\
\hline Oud-Charlois & Bedreigd & 5 & 5.4 & 5 \\
\hline Carnisse & Bedreigd & 5 & 4.4 & 5.6 \\
\hline Zuidwijk & Aandacht & 5.4 & 5.4 & 6.3 \\
\hline Heijplaat & Veilig & 7.5 & 8.2 & 7.6 \\
\hline Wielewaal & Veilig & 8 & 7.9 & 8.2 \\
\hline Charlois & Bedreigd & 4.7 & 4.7 & 5.1 \\
\hline Rotterdam & Aandacht & 5.6 & 5.6 & 6.2 \\
\hline
\end{tabular}

Bron: Veiligheidsindex Rotterdam, 2004

Los van de Veiligheidsindex kunnen we de veiligheidssituatie in de Tarwewijk, Charlois en Rotterdam ook beoordelen aan de hand van het aantal delicten dat bij de politie Rotterdam-Rijnmond bekend is. Tabel 4.4 geeft inzicht in zowel het totale aantal delicten als in het aantal delicten per duizend inwoners. De belangrijkste bevinding uit de tabel is dat het politieoptreden in de Tarwewijk sinds eind jaren negentig in zoverre succesvol was dat het aantal delicten per duizend inwoners in deze wijk behoorlijk is teruggelopen (met bijna $7 \%$ ). De ontwikkeling in de Tarwewijk is hiermee beduidend gunstiger dan in heel Charlois (een kleine daling van het aantal delicten per duizend inwoners met ongeveer I procent) en in heel Rotterdam (een kleine stijging van het aantal delicten per duizend inwoners). Wanneer we alleen kijken naar de delicten op het gebied van veiligheid (zoals diefstal en inbraak woning, diefstal van en uit auto's, zakkenrollerij, maar ook geweldsdelicten zoals geweld tegen persoon, bedreiging, mishandeling, straatroof en overvallen), dan is de verbetering in de Tarwewijk nog meer evident. Wat verder opvalt in deze tabel is dat het aantal delicten in de Tarwewijk verhoudingsgewijs lager ligt dan in heel Charlois en heel Rotterdam. 
Op basis van deze gegevens lijkt de veiligheidssituatie in de Tarwewijk dus minder ernstig te zijn dan we op basis van de score op de Veiligheidsindex zouden verwachten. Echter, we moeten de onveiligheid in de Tarwewijk op basis van deze gegevens niet al te veel relativeren. In de eerste plaats is het bekend dat er in stadscentra over het algemeen veel meer delicten plaatsvinden dan in woonbuurten als de Tarwewijk. In de tweede plaats is het goed mogelijk dat lang niet alle in de Tarwewijk gepleegde delicten bij de politie bekend zijn. Statistische gegevens over aantallen verdachten of delicten hebben altijd te maken met een darknumber, en het ligt voor de hand dat deze niet geregistreerde criminaliteit in een buurt als de Tarwewijk groter is dan elders in de stad.

De gemeente vindt het veiligheidsprobleem in de Tarwewijk in ieder geval dusdanig dringend dat er van de negen in Rotterdam aangewezen 'hotspot-gebieden' maar liefst drie in de Tarwewijk liggen. Hotspot-gebieden zijn "die straten of buurten die zich bevinden of terecht dreigen te komen in de negatieve spiraal waarin criminaliteit, verloedering en vervuiling het beeld bepalen"7. De hotspotgebieden in de Tarwewijk zijn de Dordtselaan, de Bas Jungeriusstraat en de Katendrechtse Lagendijk.

\section{Tevredenheid met de buurt}

Onderzoek laat zien dat de bewoners van Charlois relatief vaak ontevreden zijn met de buurt. Zo is in Charlois slechts 59 procent van de bewoners tevreden met de eigen buurt, terwijl 74 procent van de bewoners van Rotterdam dat is. Als grootste buurtproblemen in Charlois worden vuil naast de container, overlast van groepen jongeren en vervuiling op straat genoemd. Verder wordt drugsoverlast als groot probleem ervaren. Ruim een op de vijf bewoners vindt drugsoverlast een veelvoorkomend buurtprobleem, terwijl bijna een op de zes bewoners van Rotterdam dit zo ervaart (Gemeente Rotterdam, 2004). Binnen de Tarwewijk worden met name de Millinxbuurt en de Dordtselaan met drugsoverlast geconfronteerd. De buurtconciërge zegt hierover:

“De Millinxbuurt is altijd een buurt voor junks en zwervers geweest. Die willen 's nachts onderdak, dus ze pakken het eerste wat leegstaat. Ze braken dus altijd leegstaande panden open. En het is niet erg als ze kraken, maar ze maken er zo'n teringzooitje van. Om de haverklap lagen er junks te slapen en wat kom je tegen in opgebroken panden? Ja, spuiten, vuilniszakken... Als bewoner irriteert het je als het elke keer wordt opengebroken. Als je 's morgens langsloopt, dan zie je dat het weer opengebroken is. Ja, dan moet je weer de woningcorporatie of deelgemeente waarschuwen” (Resp. R7) ${ }^{8}$.

In Desmet et al. (2003) schat een respondent dat er zo'n dertig à veertig drugsdealers in de buurt actief zijn. Desmet et al. (2003) beschrijft overigens dat er ondanks alle problemen toch aardig wat bewoners tevreden zijn met hun woonsituatie. Zo wordt het contact met de buren als positief ervaren, evenals de aanwezigheid van familie; tevens blijkt dat met name de geïnterviewde bewoners van buitenlandse afkomst die nog niet zo lang in de buurt wonen, geen verval 
Tabel 4.4 Aantal delicten bij de politie bekend in Tarwewijk, Charlois en Rotterdam (1999-2003)

\begin{tabular}{|c|c|c|c|c|c|c|}
\hline & 1999 & 2000 & 2001 & 2002 & 2003 & $\begin{array}{r}1999 \\
=100\end{array}$ \\
\hline \multicolumn{7}{|l|}{ Tarwewijk (buurt 71) } \\
\hline 1. Veiligheid & 1275 & 1236 & 1260 & 1077 & 1148 & 90.0 \\
\hline 2. Leefbaarheid & 158 & 146 & 186 & 204 & 276 & 174.7 \\
\hline 3. Maatschappelijke integriteit & 29 & 38 & 18 & 17 & 32 & 110.3 \\
\hline Totaal aantal delicten Tarwewijk & 1462 & 1420 & 1464 & 1298 & 1456 & 99.6 \\
\hline Aantal inwoners & 11396 & 11306 & 11380 & 11842 & 12142 & 106.5 \\
\hline Delicten per 1000 inwoners & & & & & & \\
\hline 1. Veiligheid & 111.9 & 109.3 & 110.7 & 90.9 & 94.5 & 84.5 \\
\hline 2. Leefbaarheid & 13.9 & 12.9 & 16.3 & 17.2 & 22.7 & 164.0 \\
\hline 3. Maatschappelijke integriteit & 2.5 & 3.4 & 1.6 & 1.4 & 2.6 & 103.6 \\
\hline Totaal Tarwewijk & 128.3 & 125.6 & 128.6 & 109.6 & 119.9 & 93.5 \\
\hline \multicolumn{7}{|l|}{ Deelgemeente Charlois } \\
\hline 1. Veiligheid & 6999 & 7340 & 6499 & 5996 & 6445 & 92.1 \\
\hline 2. Leefbaarheid & 1083 & 877 & 1202 & 1252 & 1629 & 150.4 \\
\hline 3. Maatschappelijke integriteit & 146 & 141 & 128 & 98 & 184 & 126.0 \\
\hline Totaal aantal delicten Charlois & 8228 & 8358 & 7829 & 7346 & 8258 & 100.4 \\
\hline Aantal inwoners & 65876 & 66296 & 66341 & 66851 & 66983 & 101.7 \\
\hline Delicten per 1000 inwoners & & & & & & \\
\hline 1. Veiligheid & 106.2 & 110.7 & 98.0 & 89.7 & 96.2 & 90.6 \\
\hline 2. Leefbaarheid & 16.4 & 13.2 & 18.1 & 18.7 & 24.3 & 147.9 \\
\hline 3. Maatschappelijke integriteit & 2.2 & 2.1 & 1.9 & 1.5 & 2.7 & 123.9 \\
\hline Totaal Charlois & 124.9 & 126.1 & 118.0 & 109.9 & 123.3 & 98.7 \\
\hline \multicolumn{7}{|l|}{ Gemeente Rotterdam } \\
\hline 1. Veiligheid & 61289 & 67784 & 66266 & 65453 & 60031 & 97.9 \\
\hline 2. Leefbaarheid & 10565 & 9581 & 12541 & 14264 & 13517 & 127.9 \\
\hline 3. Maatschappelijke integriteit & 1311 & 1257 & 1156 & 1399 & 1825 & 139.2 \\
\hline Totaal aantal delicten Rotterdam & 73165 & 78622 & 79963 & 81116 & 75373 & 103.0 \\
\hline Aantal inwoners & 592597 & 592660 & 595389 & 598467 & 599859 & 101.2 \\
\hline Delicten per 1000 inwoners & & & & & & \\
\hline 1. Veiligheid & 103.4 & 114.4 & 111.3 & 109.4 & 100.1 & 96.8 \\
\hline 2. Leefbaarheid & 17.8 & 16.2 & 21.1 & 23.8 & 22.5 & 126.4 \\
\hline 3. Maatschappelijke integriteit & 2.2 & 2.1 & 1.9 & 2.3 & 3.0 & 137.5 \\
\hline Totaal Rotterdam & 123.5 & 132.7 & 134.3 & 135.5 & 125.7 & 101.8 \\
\hline
\end{tabular}

Toelichting:

Veiligheid = diefstal/inbraak woning, diefstal uit/vanaf motorvoertuigen, diefstal van motorvoertuigen, bromen fietsdiefstal, zakkenrollerij, zedenmisdrijf, (poging tot) moord, doodslag: misdrijven voltooid, openlijk geweld tegen persoon, bedreiging, mishandeling, straatroof, overval (woning, bedrijven en instellingen). Leefbaarheid = drugsoverlast en -misdrijven, vernieling/zaakbeschadiging, diefstal/inbraak uit bedrijven en instellingen, winkeldiefstal.

Maatschappelijke integriteit = drugshandel: misdrijven, fraude en bedrog, mensenhandel, discriminatie, enz.

Bron: Politie Rotterdam-Rijnmond 
waarnemen en tevreden zijn over de buurt. Echter, over het specifieke deel van de Millinxbuurt werden door de respondenten geen sterke punten genoemd.

De ontevredenheid met de buurt komt ook tot uiting in de hoge mutatiegraad van de bewoners. Bijna één op de drie (29\%) bewoners van de Tarwewijk woont slechts 1 jaar of minder in de buurt en verhuist dan weer (in Rotterdam 19\%). Het percentage adressen in de Tarwewijk waar 5 of meer jaar dezelfde bewoners wonen is slechts 43 procent, terwijl dit in Rotterdam 59 procent is (zie tabel 4.2). Een grote doorstroom van bewoners bemoeilijkt het ontstaan van sociale cohesie. Buren kennen elkaar amper, omdat ze er maar kort wonen. Volgens Dominic Schrijer is de sociale cohesie in de Millinxbuurt dermate weggevloeid dat er sprake is van:

“totale onleefbaarheid en totale afwezigheid van vitaliteit” (Resp. R8).

De sociale controle vermindert waardoor de leefsituatie van de achterblijvers steeds onzekerder wordt. Bewoners en professionals vertellen hierover:

“De goede bewoners vertrekken. Mensen die de mogelijkheden hebben de buurt te verlaten, doen dat. Het enige belang dat voor deze mensen nog telt is hun huis zo gunstig mogelijk verkopen, zoals aan huisjesmelkers, zodat het verlies beperkt blijft. Dit proces is al jaren aan de gang en gaat tot op de dag van vandaag nog steeds door."9

"Wat ook een verontrustende ontwikkeling is, is dat verschrikkelijk veel mensen het idee hebben dat ze daar niet thuishoren. Er is een enorm grote mutatiegraad van mensen die tijdelijk wonen en dan vervolgens weer verhuizen. De sociale cohesie is zoek in dit soort gebieden. Want ze kennen hun eigen buren niet. Wat ook weer tot gevolg heeft dat er allerlei onveiligheidsgevoelens spelen. Dat is natuurlijk lastig" (Resp. R5) ${ }^{10}$.

Bewoners willen niet investeren in de woning en in sociale contacten in de buurt, omdat ze denken snel weer te vertrekken:

“Een belangrijk aspect is een hele hoge mobiliteit van mensen in bijvoorbeeld Tarwewijk. Gemiddeld was in zo'n wijk, en dan praat je over zo'n twaalf duizend bewoners, in nog geen twee jaar tijd 47 procent van die bevolking verhuisd, 47 procent, moet je eens voorstellen wat dat betekent! Maar het totale aantal blijft hetzelfde. Hoe kan dan zoiets als een portiekgesprek werken: een gesprek met de buurman van gisteren, met die van vandaag, of met die van morgen. Het is anoniem, mensen hebben dus geen hechting" (Resp. $\left.\mathrm{R}_{3}\right)^{11}$.

\subsubsection{WONINGVOORRAAD EN STEDELIJKE HERSTRUCTURERING}

Volgens deskundigen hangen de veiligheids- en leefbaarheidsproblemen in de Tarwewijk en in heel Charlois sterk samen met de structuur van de woningvoor- 
raad en de woningmarkt in dit gebied. De huurprijzen in de Tarwewijk zijn relatief laag, wat lage inkomensgroepen aantrekt. Met name de Millinxbuurt heeft aantrekkingskracht op bewoners die behoefte hebben aan een 'lage huur en een huisbaas die geen vragen stelt' (Aalbers 2004).

Door de lage huren en het grote aantal kleine particuliere eigenaren is de Millinxbuurt een aantrekkelijke locatie voor drugsgebruikers, dealers, andere kleine criminelen, illegale vreemdelingen - met andere woorden, voor iedereen die geen toegang heeft tot de reguliere arbeidsmarkt en is aangewezen op wat wel het 'souterrain van de stedelijke woningmarkt' wordt genoemd. Huizen waar voorheen gezinnen woonden worden opgesplitst in kleine kamertjes die apart verhuurd worden. In sommige kamers, soms zelfs zonder raam, is er slechts plaats voor een bed en een kledingkast. Het toilet en de douche worden gedeeld door de bewoners. (Botman en Van Kempen 200o). Zo wordt geschat dat in de deelgemeente Charlois in 2000 ten minste 300 panden voor de huisvesting van illegalen gebruikt werden. In sommige straten gaat het om een derde van de woningen (Aalbers 2004). De meeste illegalen in de Millinxbuurt blijken bovendien met meerdere personen een kamer te delen. Soms wordt een appartement gedeeld door vijf tot vijftien personen. Voor de huisjesmelkers is de verhuur aan illegale migranten een lonende activiteit; de gemiddelde prijs per bed bedraagt 50 tot 100 euro per week. Met name de kleine drugsdealers vertonen crimineel gedrag en trekken weer andere mensen uit het criminele circuit aan (Botman en Van Kempen 2001).

Wat het allemaal nog complexer maakt is de grote leegstand in de buurt. Zoals gezegd, vertrekken veel bewoners van de Tarwewijk weer snel uit de wijk. De verlaten huizen worden vervolgens moeilijk verhuurd, waardoor veel panden (tijdelijk) leeg komen te staan. De administratieve leegstand is in de Tarwewijk bijna tweemaal zo hoog als in heel Rotterdam (tabel 4.2). Juist in de leegstaande panden ontstonden veel problemen, zoals het openbreken door drugsverslaafden. Het leegstaan van panden heeft bovendien een zichzelf versterkende werking: naarmate meer panden leegstaan in een straat, wordt het minder aantrekkelijk om er te wonen, waardoor er meer mensen verhuizen en er zich minder mensen zullen vestigen, waardoor er uiteindelijk weer meer panden leeg komen te staan. De leegstand wordt mede veroorzaakt door de slechte woningmarkt in de Tarwewijk, waardoor het voor kopers een te groot risico is om een pand te kopen en op te knappen.

"De vastgoedontwikkeling is zo slecht dat het niet rendabel is om hier een pand te kopen, op te knappen en weer te verkopen of verhuren. Dus de benodigde investering een pand hier weer geschikt te maken voor bewoning, is zo groot dat het niet meer terug te verdienen valt. En daarom staan ze leeg. Je ziet dat ook in Liverpool, waar een derde van alle woningen leeg staat. Niemand wil die troep hebben. Ik bedoel, als de koopkracht weg is uit de stad, is er ook geen vraag naar woningen. In Amsterdam zit de vastgoedmarkt anders in elkaar. Daar is meer vraag naar woningen en dat maakt het ook lucratief om in huizen te investeren en ze weer op te knappen en te 
verkopen. Je weet dat je je investering er binnen enkele jaren dik uithaalt, op een legale of illegale manier. De prijs per vierkante meter op de Dordtselaan (in de Tarwewijk) is maar de helft of een derde ten opzichte van Blijdorp (in Rotterdam-Noord) en in Amsterdam. Voor de prijs van een klein uitgewoond appartement in de Pijp kun je in de Tarwewijk een heel pand kopen” (Resp. R8).

Een ander probleem is de hypotheekverstrekking voor mensen die toch een woning willen kopen in buurten als de Tarwewijk. Eind jaren negentig verstrekten banken niet of nauwelijks hypotheken voor woningen in de Millinxbuurt. Dit verschijnsel wordt wel redlining genoemd. Zo gebruikte een bank een plattegrond waarop bepaalde gebieden (waaronder de Tarwewijk) rood waren gekleurd, waarvoor geen hypotheek mocht worden afgegeven. Een andere bank had een postcodelijst waarbij achter de postcode 3081 (van de Tarwewijk) stond 'niet financieren'. Financiële instellingen wensen in deze buurten geen hypotheken te verstrekken, omdat ze vrezen dat de woningprijzen er verder zullen zakken en ertoe kan leiden dat de koper de hypotheek niet kan aflossen. Redlining leidt tot vraaguitval en daarmee tot nog lagere prijzen op de formele woningmarkt, wat ertoe leidde dat veel woningen in het bezit kwamen van de onderwereld (Aalbers 2004).

Vooral panden die onrechtmatig of overbewoond worden en in het bezit zijn van malafide huiseigenaren veroorzaken veel problemen binnen de Tarwewijk. Wanneer een klein aantal overlast gevende panden wordt aangepakt, heeft dat een enorme uitwerking op de rest van de buurt.

“Kijk, mijn eerste opdracht was vijf jaar gelden op de Dordtselaan. Er waren toen om een voorbeeld te noemen 130 appartementen in het bezit van verkeerde huurders. Die 130 appartementen zijn nu opgekocht door de wijkontwikkelingsmaatschappij Tarwewijk. Van die 130 appartementen staan er nu 30 leeg. Die worden opgeknapt en particulier verkocht. Dat heeft een enorme impact. Die 30 appartementen die we gesloten hebben, vormen maar 1o procent van het hele woningbestand dat we aangepakt hebben. Maar die 10 procent veroorzaakte misschien wel 90 procent van de overlast in de buurt” (Resp. R5).

Veel van bovengeschetste problemen waren in eerste instantie alleen zichtbaar in een deel van de Tarwewijk, in de Millinxbuurt. De omringende buurten lijken echter te kampen met een spill-over-effect: door de vele aandacht voor en inspanningen in de Millinxbuurt verplaatsen problemen van criminaliteit, drugsoverlast, et cetera, zich ten dele naar aangrenzende buurten als bijvoorbeeld de Tarwebuurt (Botman en Van Kempen 2001). Daarom worden er nu bijvoorbeeld ook interventieteams en buurtconciërges ingezet in omliggende wijken als in OudCharlois en Carnisse.

Ondanks alle problemen in de Tarwewijk is deze wijk pas in 1999 door de gemeente aangewezen als gebied voor het grotestedenbeleid. De middelen zullen met name aangewend worden voor fysieke maatregelen, zoals de herstructurering van de wo- 
ningvoorraad. Het doel van de stedelijke herstructurering in de Tarwewijk is meer variatie in de woningvoorraad, waarbij ingezet word t om de bewoners die er wonen te behouden. Een toename van variatie van de woningvoorraad bied t bewoners de mogelijkheid tot een wooncarrière. Het plan is om het eigenwoningbezit tussen 2001 en 2010 zal toenemen van 23 tot 50 procent. Het aantal grote woningen (met 4 of meer kamers) zal vermeerderen van 27 tot 40 procent. Het aandeel eengezinswoningen moet toenemen van 5 tot 15 procent. In veel delen van de Tarwewijk wordt nu gerenoveerd. De gemeente koopt particuliere huurwoningen aan, die worden afgebroken of opgeknapt om ze daarna te verhuren of te verkopen. In de Millinxbuurt is er een groot contrast waarneembaar. Zo zijn er blokken die wachten op renovatie of afbraak. Deze staan (bijna) leeg en zijn dichtgetimmerd. En er zijn woningen soms letterlijk aan de overkant van de straat, die nieuw gebouwd zijn of opgeknapt (Botman en van Kempen 2002).

Over het algemeen duurt het proces van herstructurering of renovatie in de Tarwewijk lang, omdat men hier met vele (particuliere) eigenaren te maken heeft. De bewoners zijn de laatste jaren voortdurend in afwachting geweest van een stadsvernieuwing en hebben daarom niet meer in hun huis willen investeren waardoor de buurt in een korte periode snel verpauperde.

"Niemand investeert een spijker in zijn huis dat op de nominatie staat eens gesloopt te worden. De wijk holt vervolgens achteruit." 12

\subsubsection{ONDERWIJSACHTERSTAND EN SCHOOLUITVAL}

Zoals al aangegeven is, is een van de gevaren van een achterstandswijk dat sociale achterstand wordt overgedragen van de ene op de andere generatie doordat allochtone leerlingen onvoldoende schoolresultaten behalen. Allochtone leerlingen beginnen hun basisschoolcarrière vaak met een achterstand die ze nadien moeilijk inhalen en stromen derhalve gemiddeld vaker door naar de lagere niveaus van het middelbaar onderwijs. De Tarwewijk heeft een relatief jonge bevolking, een hoog percentage allochtonen en veel zwarte scholen. De lage huurprijzen in de wijk trekken bovendien veel asielzoekers en illegale vreemdelingen aan. Het effect is dat veel scholen in de Tarwewijk geconfronteerd worden met leerlingen met leerproblemen: zoals moeite met de Nederlandse taal of een gebrek aan algemene kennis.

Het basisonderwijs in Rotterdam en in Charlois in het bijzonder kent veel 'zware leerlingen'. Hiermee wordt gedoeld op het leerlinggewicht van kinderen. Kinderen van ouders met een laag opleidings- of beroepsniveau en/of een allochtone herkomst krijgen een hoger leerlinggewicht toegekend (maximaal 1,9). Een school met meer achterstandsleerlingen krijgt meer financiële middelen. Het Cito gebruikt deze gegevens over leerlinggewichten van kinderen om scholen in te delen in zeven schoolgroepen. Hoe meer achterstandsleerlingen een school telt, des te hoger de schoolgroep. In Rotterdam behoort bijna 45 procent van alle 
basisscholen tot groep 7 (d.w.z. een school met minstens 75 procent 1,9-leerlingen), in de Tarwewijk behoren drie van de vier basisscholen tot deze groep 7. Landelijk behoort slechts rond 5 procent van alle basisscholen tot deze groep met de meeste achterstandsleerlingen. ${ }^{13}$

In Nederland worden de schoolresultaten van basisschoolleerlingen nauwkeurig bijgehouden, en is er van iedere basisschool de gemiddelde Cito-score bekend. Omdat het weinig zinnig is om resultaten van scholen met veel en met weinig achterstandsleerlingen met elkaar te vergelijken, worden in tabel 4.5 de gemiddelde Cito-scores per schoolscoregroep (SSG) weergegeven. In de tweede en derde kolom van de tabel ziet men de gemiddelde Cito-scores van scholen in Rotterdam en heel Nederland. Uit de gegevens leren we dat Rotterdamse basisscholen met de minste achterstandsleerlingen (SSG 1 en 2) betere resultaten behalen dan vergelijkbare scholen in de rest van Nederland. Dit geldt echter niet voor alle andere scholen. Bij alle overige categorieën (SSG $3 \mathrm{t} / \mathrm{m}$ 7) zien we steeds dat de gemiddelde Cito-scores van Rotterdamse scholen wat lager liggen dan landelijk gemiddeld. Met andere woorden, de Rotterdamse basisscholen in deze categorieën doen het qua Cito-score gemiddeld wat minder goed dan vergelijkbare scholen in de rest van Nederland. In de derde en vierde kolom kan worden afgelezen hoe de basisscholen in de deelgemeente Charlois het doen.

We zien dat verreweg de meeste basisscholen in Charlois tot de onderste schoolscoregroepen behoren, met andere woorden tot scholen met relatief de meeste achterstandsleerlingen. De scholen uit Charlois in schoolscoregroep 5 doen het gemiddeld iets beter dan vergelijkbare scholen in heel Rotterdam en heel Nederland. De scholen in Charlois met de meeste achterstandsleerlingen (sSG 6 en 7) doen het daarentegen wat slechter dan vergelijkbare scholen in de hele stad en in het hele land. Er zijn hierop echter wel een aantal uitzonderingen. Bij de openbare basisschool De Toermalijn (SSG 6) ligt de gemiddelde Cito-score ruim boven het stedelijk en landelijk gemiddelde in dezelfde categorie. Hetzelfde geldt voor de openbare basisschool De Kameleon, de islamitische basisschool Ibn-i-Sina en de protestants-christelijke basisschool De Akker (SSG 7). Wat betreft de basisscholen in de Tarwewijk kunnen we constateren dat drie van de vier scholen een lagere gemiddelde Cito-score hebben dan vergelijkbare scholen in heel Rotterdam en heel Nederland. De gemiddelde Cito-score van alle basisscholen in de Tarwewijk bedraagt uiteindelijk 525,9 en dat is ruim 1,5 tot 2 punten lager dan de gemiddelde Cito-score van alle basisscholen met de meeste achterstandsleerlingen (SSG 7) in respectievelijk heel Rotterdam en heel Nederland.

De uiteindelijke conclusie moge luiden dat basisscholen in de Tarwewijk niet alleen beduidend meer achterstandsleerlingen hebben dan scholen elders in de stad en in Nederland, maar het, uitzonderingen daargelaten, gemiddeld ook wat slechter doen dan vergelijkbare scholen elders in de stad en in het land. 
Tabel 4.5 Gemiddelde Cito-scores van scholen in de Tarwewijk, Charlois, Rotterdam en Nederland, per schoolscoregroep (2003)

\begin{tabular}{|c|c|c|c|c|c|}
\hline $\begin{array}{l}\text { School- } \\
\text { scoregroep }\end{array}$ & Nederland & Rotterdam & Scholen in Charlois & $\begin{array}{r}\text { Gem. } \\
\text { Cito-score }\end{array}$ & Buurt \\
\hline 1 & 537,9 & 542,1 & & & \\
\hline 2 & 536,7 & 537,6 & REFBS Het Kompas & 542,5 & \\
\hline 3 & 535 & 534,7 & & & \\
\hline 4 & 533,1 & 532,2 & KBS Elisabeth & 532,6 & \\
\hline \multirow[t]{5}{*}{5} & \multirow[t]{5}{*}{532,6} & \multirow[t]{5}{*}{530,8} & Gemiddelde Charlois ssg 5 & 534,8 & \\
\hline & & & PCBS De Klaver (disl) & 541,2 & \\
\hline & & & PCBS Steven Stemerding & 533,7 & \\
\hline & & & PCBS Wilhelmina & 532,7 & \\
\hline & & & PCBS De Klaver & 531,6 & \\
\hline \multirow[t]{6}{*}{6} & \multirow[t]{6}{*}{529,4} & \multirow[t]{6}{*}{528,4} & Gemiddelde Charlois ssg 6 & 528,8 & \\
\hline & & & OBs De Toermalijn & 535,9 & \\
\hline & & & OBs De Toermalijn (dep) & 528,5 & \\
\hline & & & ICBS De Hoeksteen & 528 & \\
\hline & & & PCBS Elout van Soeterwoude & 526,7 & Tarwewijk \\
\hline & & & OBS De Triangel & 524,9 & \\
\hline \multirow[t]{11}{*}{7} & \multirow[t]{11}{*}{528,2} & \multirow[t]{11}{*}{527,5} & Gemiddelde Charlois ssg 7 & 526,3 & \\
\hline & & & OBS De Kameleon & 529,6 & \\
\hline & & & IBS Ibn-i-Sina & 529,5 & \\
\hline & & & PCBS De Akker & 529,3 & Tarwewijk \\
\hline & & & РСBS Beatrix & 528,6 & \\
\hline & & & OBs Over de Slinge & 528,5 & \\
\hline & & & OBs De Globe (dep) & 527 & Tarwewijk \\
\hline & & & OBS Charlois & 522,6 & \\
\hline & & & овs De Globe & 520,6 & Tarwewijk \\
\hline & & & KBS Cristophoor & 520,6 & \\
\hline & & & Gemiddeld Tarwewijk & 525,9 & \\
\hline
\end{tabular}

Toelichting: SSG is schoolscoregroep (SSG $7=$ scholen met minstens 75 procent achterstandsleerlingen)

Bron: Verhelst 2003 (eigen bewerking)

Een ander probleem is de grote behoefte aan nevenvoorzieningen in scholen zoals tussen- en naschoolse opvang. Een respondent werkzaam in het basisonderwijs geeft aan dat er op zijn school (in Pendrecht) een grote behoefte is aan tussenschoolse opvang, volgens haar vanwege de grote groep Antilliaanse alleenstaande moeders: 
"We zitten juist te springen om tussentijdse opvang. Het aantal overblijvers op school is waanzinnig hoog. Dat heeft te maken met de bevolkingssamenstelling, 59 Antilliaanse gezinnen [in Pendrecht]. Daarvan kun je haast zeggen dat er 58 alleenstaande moeders zijn, die op het ogenblik ook een cursus gaan volgen. Die kinderen blijven sowieso al over. Als je kijkt per dag: tussen de 60 en de 70 leerlingen. Daar heb je eigenlijk een accommodatie voor nodig, afgezien van de professionaliteit van de overblijfmoeders. Voor een kind is het ook wel eens goed om uit die ruimte te zijn. Er zijn kinderservicehotels, maar er staan ook kinderen op straat hoor, want het is voor een heleboel ouders ook onbetaalbaar. En kinderen zwerven dan op straat” (Resp. Rio) ${ }^{14}$.

Een derde probleem op onderwijsgebied betreft de veelvoorkomende voortijdige schooluitval uit het middelbare onderwijs. Tabel 4.6 laat zien dat circa 13 procent van de 15-23-jarigen in Charlois voortijdig zijn of haar schoolcarrière beëindigt. Men heeft derhalve geen minimale startkwalificatie, hetgeen een groot risico voor de latere arbeidsmarktkansen van een persoon vormt. In Rotterdam heeft een kleine tien procent van alle 15-23-jarigen geen startkwalificatie. Van alle deelgemeenten die met dit probleem te kampen hebben, neemt Charlois de vierde plaats in. In sommige deelgemeenten (Centrum, Noord en Kralingen-Crooswijk) ligt het percentage schoolverlaters zonder minimale schoolverlaters nog wat hoger dan in Charlois. Tevens kent de Tarwewijk in vergelijking met andere deelgemeenten een hoog percentage spijbelaars (zie Relatief verzuim in tabel 4.6). Samen met Stadscentrum kent Charlois met 3.9 procent het hoogste percentage leerplichtige leerlingen dat spijbelt. Ook heeft Charlois het hoogste percentage 'Absoluut verzuim', wat inhoudt dat de leerling op geen enkele school staat ingeschreven. Qua percentage bemiddelingen neemt Charlois de tweede plaats in van de 13 deelgemeenten. Bij bemiddeling is er sprake van een problematische situatie tussen school, kind en ouders, waar een leerplichtambtenaar preventief in actie komt om uitval te voorkomen. Kortom, Charlois heeft in vergelijking met de andere deelgemeenten van Rotterdam in een hoge mate te kampen met schooluitval, spijbelen, überhaupt niet naar school gaan en problematische situaties tussen school, ouder en kind waar een leerplichtambtenaar in actie moet komen.

\subsubsection{WERKLOOSHEID EN UITKERINGSAFHANKELIJKHEID}

In het verleden werkten veel van de bewoners van Charlois in de haven of aanverwante bedrijven. Doordat bedrijven wegtrokken en de havenactiviteiten gerationaliseerd, geautomatiseerd en gecomputeriseerd werden, is de werkgelegenheid in dit gebied sterk afgenomen. Dit leidde tot hoge werkloosheid in de Tarwewijk. De lokale economie in de Tarwewijk van nu biedt weinig mogelijkheden tot een baan. Het gebied telt rond 3 oo bedrijven, waaronder veel kleine ondernemingen. Door onder andere de lage huurprijzen biedt de Tarwewijk echter mogelijkheden voor etnisch ondernemerschap. Het aantal migrantenondernemers nam de laatste vijf jaar toe (dit geldt overigens voor veel wijken in Rotterdam). De lokale economie van de Tarwewijk is ongunstig vanwege het geringe aantal winkels in de wijk. Veel winkeliers waren genoodzaakt hun winkel te sluiten, deels door het groeiende aantal gezinnen met een laag inkomen, maar deels ook door de overlast 


\begin{tabular}{|c|c|c|c|c|c|c|}
\hline & \multicolumn{2}{|c|}{$\begin{array}{l}\text { Voortijdige } \\
\text { schoolverlaters } \\
\text { 5-23-jarigen }\end{array}$} & \multicolumn{4}{|c|}{$\begin{array}{l}\text { Verzuim en bemiddelingen onder } \\
\text { leerplichtige leerlingen (5-16 jarigen) }\end{array}$} \\
\hline & $\begin{array}{l}\text { Aantal } \\
\text { vsv'ers }\end{array}$ & $\begin{array}{c}\% \\
\text { vsv'ers }\end{array}$ & $\begin{array}{c}\text { Aantal } \\
\text { LPL }\end{array}$ & $\begin{array}{c}\text { \% Relatief } \\
\text { verzuim }\end{array}$ & $\begin{array}{l}\text { \% Bemid- } \\
\text { delingen }\end{array}$ & $\begin{array}{c}\% \text { Aboluut } \\
\text { verzuim }\end{array}$ \\
\hline Stadscentrum & 966 & 17.2 & 2577 & 3.92 & 1.20 & 0.93 \\
\hline Noord & 1457 & 13.2 & 6209 & 3.95 & 1.13 & 0.45 \\
\hline Kralingen/Crooswijk & 1600 & 13.2 & 7070 & 3.34 & 1.37 & 0.55 \\
\hline Charlois & 2032 & 12.6 & 8883 & 3.88 & 1.19 & 1.04 \\
\hline Delfshaven & 2339 & 11.4 & 12459 & 3.61 & 0.94 & 0.71 \\
\hline Feijenoord & 1875 & 9.6 & 12938 & 3.43 & 0.90 & 0.78 \\
\hline IJsselmonde & 1063 & 7.5 & 9777 & 2.87 & 1.04 & 0.70 \\
\hline Overschie & 234 & 7.1 & 2230 & 2.96 & 0.94 & 0.54 \\
\hline Hillegersberg/ Schiebroek & 497 & 6 & 5858 & 1.40 & 0.96 & 0.34 \\
\hline Hoogvliet & 487 & 5.8 & 6168 & 1.77 & 0.96 & 0.57 \\
\hline Prins Alexander & 992 & 5.7 & 12808 & 1.45 & 0.87 & 0.20 \\
\hline Pernis & 52 & 5.4 & 688 & 3.78 & 0.73 & 0.44 \\
\hline Hoek van Holland & 104 & 5.2 & 1421 & 0.77 & 0.70 & 0.35 \\
\hline Buiten Rotterdam & & & 68 & 8.82 & 11.76 & 11.76 \\
\hline Rotterdam & 13698 & 9.8 & 89169 & 2.90 & 1.02 & 0.62 \\
\hline
\end{tabular}

Toelichting:

Aantal vsv'ers $=$ Aantal voortijdige schoolverlaters: jongeren tot 23 jaar die het onderwijs hebben verlaten zonder startkwalificatie.

Aantal LPL $=$ Aantal leerplichtige leerlingen (5-16-jarigen).

$\%$ Relatief verzuim $=$ Relatief verzuim als percentage van het aantal leerplichtige leerlingen: leerling spijbelt.

$\%$ Bemiddelingen $=$ Bemiddelingen als percentage van het aantal leerplichtige leerlingen: vaak problematische situatie tussen school, kind en ouders. De leerplichtambtenaar komt dan preventief in actie om uitval te voorkomen.

$\%$ Absoluut verzuim $=$ Absoluut verzuim als percentage van het aantal leerplichtige leerlingen: leerling staat op geen enkele school ingeschreven.

Bron vsv: Dienst Stedelijk Onderwijs, 2003. De Rotterdamse Monitor Voortijdig Schoolverlaten, 2-meting. Binnen is winnen, Rotterdam: Dienst Stedelijk Onderwijs

Bron verzuim: Dienst Stedelijk Onderwijs, 2003

en criminaliteit in de wijk. In met name de Millinxbuurt bleven veel klanten weg uit angst om beroofd te worden. In de winter sloten er sommige winkels vroeger, om niet aangevallen te worden in het donker. Klanten vroegen de winkelbedienden of ze mee wilden lopen naar hun auto en nieuwe klanten durfden de buurt niet meer in. De bewoners van de Tarwewijk doen hun meeste inkopen in het winkelcentrum Zuidplein (Botman en van Kempen 2001). 


\begin{tabular}{|c|c|c|c|c|c|c|}
\hline & \multicolumn{2}{|c|}{ Tarwewijk } & \multicolumn{2}{|c|}{ Charlois } & \multicolumn{2}{|c|}{ Rotterdam } \\
\hline & 2000 & 2003 & 2000 & 2003 & 2000 & 2003 \\
\hline aantal inwoners $15 \mathrm{t} / \mathrm{m} 64$ jaar & 8363 & 8989 & 44092 & 45298 & 398823 & 408536 \\
\hline aantal bijstand tot 65 jaar $^{1}$ ) & 1426 & 1662 & 6057 & 6519 & 44540 & 42259 \\
\hline$\%$ werkenden (netto participatie) & - & - & 56 & 55 & 57 & 58 \\
\hline$\%$ bijstand tot 65 jaar & 17,1 & 18,5 & 13,7 & 14,4 & 11,2 & 10,3 \\
\hline$\%$ geregistreerde werklozen ${ }^{2}$ ) & - & - & 5 & 14 & 6 & 13 \\
\hline$\%$ huishoudens met een laag & & & & & & \\
\hline & 32 & - & 25 & - & 22 & - \\
\hline
\end{tabular}

Toelichting:

1) Bijstand: ABW tot 65 jaar, IOAW/ IOAZ (tot 65 jaar)

2) $2003=2002$

Bron: Gemeente Rotterdam, cos

Er zijn geen gegevens beschikbaar over het aantal werkenden en werklozen in de Tarwewijk. In de deelgemeente Charlois ligt het aandeel werkenden (nettoarbeidsparticipatie) niet veel lager dan gemiddeld in de stad en verschilt ook het werkloosheidscijfer in Charlois niet veel van het stedelijk gemiddelde. De gegevens laten zien hoe snel de werkloosheid in zowel Charlois als heel Rotterdam in de afgelopen jaren is gestegen. In Charlois is het aantal werklozen tussen 2000 en 2003 bijna verdrievoudigd.

Het grootste probleem in de Tarwewijk is het hoge aantal bijstandsontvangers: 17 procent van alle volwassenen tussen 15 en 64 jaar ontvangt er een bijstandsuitkering, tegen 14,5 procent in Charlois en ruim 10 procent in heel Rotterdam. Een respondent geeft aan dat het aantal uitkeringen op de Dordtselaan zorgwekkend is.

“Nou, waar je je natuurlijk zorgen over kunt maken is dat er verschrikkelijk veel mensen wel woonachtig zijn, maar niet werken. Het is een arm gebied. Ik bedoel, op de Dordtselaan komen zo tussen de 200 en 250 uitkeringen binnen van de 800 appartementen die er zijn. Trek daar de oudere mensen van af, trek daar de WAO'ers van af, dan zullen er maar weinig mensen werken op de Dordtselaan. Dat is een zorgwekkende ontwikkeling” (Resp. R5).

De reïntegratie op de arbeidsmarkt van uitkeringsontvangers blijkt een moeilijke opgaaf voor de (deel)gemeente. Een strenge controle aan de poort, dus bij de aanvraag van uitkeringen, blijkt echter wel zijn vruchten af te werpen. Zo worden in Charlois jongeren die een uitkering aanvragen op gesprek gevraagd wanneer zij een aanvraag doen. Hierdoor besluit een deel van hen de aanvraag toch niet door te zetten en valt een deel 'door de mand'. Het aantal uitkeringsaan- 
vragen van jongeren is op deze manier afgenomen. ${ }^{15}$ De gemeente wil in heel Rotterdam met dit doel een huisbezoek afleggen bij een deel van de uitkeringsaanvragers. ${ }^{16}$

Een ander, hiermee samenhangend probleem, betreft het hoge aantal huishoudens met een laag inkomen. Een op de drie huishoudens in de Tarwewijk moest in 2000 rondkomen van een 'laag inkomen' (dat overigens wel hoger is dan het sociaal minimum). In heel Rotterdam heeft één op de vijf huishoudens een dergelijk laag inkomen. De reden van het hoge aantal lage inkomens in de Tarwewijk is onder meer het woningaanbod (veel goedkope huur- en koopwoningen), dat veel starters en mensen met weinig geld aantrekt.

Volgens zegslieden is de hoge werkloosheid in Charlois niet alleen te wijten aan de krappe arbeidsmarkt:

"Er is hier in de buurt genoeg vraag naar laaggeschoold werk. Alleen moeten mensen wel een handleiding kunnen lezen, op tijd komen en normale omgangsvormen met hun baas ontwikkelen. Dus aan de meest basale voorwaarden om te kunnen werken. Bij veel werkzoekenden in Charlois ontbreekt het hieraan. Want een vorkheftruck rijden is leuk werk, maar je moet wel kunnen lezen en schrijven en je aan de regels van het bedrijf kunnen houden. Dan vallen al heel wat jongeren af, dat is heel triest. Dat komt niet omdat ze het niet kunnen hoor. Als ze zelf willen, kunnen ze het best" (Resp. R8).

Met name onder Antilliaanse jongeren ligt de werkloosheid hoog, wat volgens Henry Breeveld, directeur van Stichting Welzijnsbevordering Antillianen/Arubanen, deels te wijten is aan onjuiste beeldvorming van een beroep.

"Het werk wat ze kunnen doen sluit wel aan bij de opleiding die ze hebben, maar niet bij de perceptie van die jongeren, bij hun beroepsbeeld (...). Het beroepsbeeld wordt gevormd vanuit de percepties zoals die op de Antillen zijn. (...) Je moet als hulpverlener heel duidelijk weten wat het beroep op de Antillen inhoudt, welk beeld de jongeren daarvan hebben en aan de hand daarvan probeer je dat beeld bij te stellen. Op de Antillen is de bouw bijvoorbeeld heel anders georganiseerd dan in Nederland. Hier zijn het allemaal segmenten, specialistisch en daar word je bij alles betrokken; je gaat de ene keer metselen en de andere keer ramen inzetten” (Resp. R2) ${ }^{17}$.

Er zijn in het verleden verscheidene projecten ondernomen om jongeren uit Charlois weer aan het werk te krijgen. Helaas zijn de meeste projecten echter beëindigd. Een van de problemen bij de bestrijding van de werkloosheid onder jongeren door de Dienst SoZaWe blijkt de hoge mutatiegraad van de jongeren die een uitkering hebben. 
"De verhouding ligt dat er in Charlois rond de 16 oo jongeren (tussen 16 en 23) ingeschreven staan die werkzoekend zijn. En op dit moment zijn er zo rond de 525 die een uitkering hebben. Dus het overgrote deel heeft geen uitkering, doet daar geen beroep op, is wel werkzoekend, maar zit misschien op school, werkt parttime, of wil verbetering. (...) Van een bestand van 7oo jongeren in de bijstand is er een mutatiegraad van rond de 600 op jaarbasis. Dus dan heb je er met 1300 te maken, maar voor 700 krijg je een formatie” (Resp. $\mathrm{R}_{3}$ ).

\subsubsection{OVERIGE PROBLEMEN}

\section{Onjuiste gegevens}

Een ander probleem dat aangegeven wordt, is dat veel gemeentelijke instellingen over onjuiste gegevens of over een gebrekkige administratie beschikken. Veel instellingen zijn voor hun uitvoering afhankelijk van die gegevens, en wanneer die onjuist blijken te zijn, kan de uitvoering moeizaam, inefficiënt en ineffectief verlopen. Zo wordt een groot deel van de uitkeringen onrechtmatig verstrekt, doordat mensen onjuiste adressen opgeven en dit niet bekend is bij de gemeente.

“Als ik hier naar de overkant kijk, daar staan 36 mensen ingeschreven op die 1o panden en ik kan op basis van documenten zo 23 namen schrappen die er niet kunnen wonen. Hetzij omdat er een ijzeren plaat voor de deur zit, nou daar kom je niet doorheen, hetzij een pand wat in de zomer op de veiling leeg verkocht is, dus de volgende periode kun je er niet wonen. (...) Er zijn een heleboel organisaties die afhankelijk zijn van de plek waar iemand ingeschreven staat. Ja, dan kan je als Dienst Stedelijk Onderwijs bijvoorbeeld honderd brieven sturen, maar die gaan nooit door die ijzeren plaat heen en die jongen is daar ook niet, die ga je nooit bereiken ook. En waarom niet? Omdat die daar gewoon niet woont. Maar dat genereert wel werk. En als dan ook blijkt dat vooral in oude stadswijken GBA, de burgerregistratie, grote onregelmatigheden vertoont: kan je nagaan wat een enorme berg werk dat oplevert, wat je in feite zo van tafel kunt schuiven, omdat het per definitie waardeloos is, omdat die figuur er niet woont. (...) Op een gegeven moment waren ze in de Millinxstraat de hele gevelwand aan het renoveren. Daar kon je dus dwars door heen kijken. Bij de Sociale Dienst stonden daar mensen ingeschreven” (Resp. R3).

"En we kennen zelf in de Millinxbuurt het geintje dat er een, twee jaar na de sloop van een aantal panden, op dat adres bij burgerzaken nog steeds mensen ingeschreven stonden. Dat in het pand van het projectbureau 14 mensen stonden ingeschreven als woonachtig en die dus uitkering kregen ook. Toen hebben ze doorgezocht dat zelfs op het stadhuis mensen stonden ingeschreven. Op Coolsingel nummer zoveel. Ja, ze proberen het, en ze krijgen het. Je lacht je toch rot als je zo makkelijk geld kunt verdienen” (Resp. R8).

"Het scheelt al heel erg op het moment dat de boel opgeschoond wordt. De eerste ervaringen in Charlois zijn dat 30 of 40 procent van de uitkeringen onrechtmatig wordt verstrekt, 30 of 40 procent. Maar dan heb je het echt over de slechtste stukken van de Tarwewijk. Ik denk dat in heel Rotterdam 20 tot 25 procent van je uitkeringsbestand kunt opschonen. Op jaarbasis is dat vele honderden miljoenen euro's die je bespaart. Als je die nou inzet voor een begeleiding van je werkzoekenden” (Resp. R3). 


\section{Jongeren}

Charlois blijkt te kampen met een grote groep risicojongeren. Anno 2003 wordt het aantal risicojongeren geschat op 5 tot 15 procent van het totaal aantal jongeren van 0-24 jaar dat in Charlois woont, wat neerkomt op 1050 tot 3150 risicojongeren. ${ }^{18}$ Door bewoners en winkeliers wordt er veel geklaagd over hanggroepjongeren en criminaliteit. Dit gedrag wordt relatief vaker vertoond door Antilliaanse jongeren wat volgens Henry Breeveld vaak wordt veroorzaakt door problemen binnen het gezin.

"De groep waar we ons vanuit de projecten nu voornamelijk op richten is de groep van jongeren van 16,18 tot 23 jaar. Daar richten de meeste projecten zich op. Terwijl het probleem vaak zit binnen de gezinnen. Het zijn de wat ouderen, rond de 35 jaar. En dat zijn de mensen die ook het verste van de Nederlandse samenleving afstaan. Als je groepjes jongeren op straat tegenkomt, is een groot deel daarvan leerplichtig. Als je ze's avonds op straat tegenkomt is dat omdat dat de plek is waar ze de ruimte vinden om met elkaar te kunnen praten. Dat lukt thuis niet. Thuis is het een rotzooi, zijn er grote gezinnen. En het hele gebeuren binnen dat gezin speelt zich in feite af op de Antillen. Maar die kinderen zitten in Nederland, die zitten op een Nederlandse school. En dat sluit niet altijd even goed aan. Dus zij kiezen voor de straat. Vaak hebben deze ouders minder scholing genoten dan hun kind van 12 jaar nu heeft. Die hebben geen vat meer op de situatie" (Resp. R2).

Andere problemen die voorkomen bij een beperkt deel van de Antilliaanse bevolking zijn een hoog aantal jonge alleenstaande moeders en een schuldenproblematiek, waardoor men in sommige gevallen overgaat tot criminele activiteiten.

"Het komt eigenlijk op één ding neer: dat mensen om allerlei redenen in financiële problemen komen en niet overweg kunnen met het Nederlandse stelsel, nooit hebben gedacht in termen van het houden van potjes of budgetteren of wat dan ook en dan gigantisch in de problemen komen: schulden. En dan zelf naar oplossingen gaan zoeken. Dat dringt helemaal door in het hele gezin en alles wat daarmee samen hangt (...)" (Resp. R2).

Met name de schulden die in het grijze en zwarte circuit plaatsvinden, vormen een groot probleem voor sommige jongeren die soms geen andere weg zien dan drugs te gaan transporteren. Henry Breeveld zegt hierover:

"Er zijn ook afspraken die ze binnen de gemeenschap met derden hebben. Dat zijn onderlinge leningen, transporten die hebben plaatsgevonden, alles in het grijze en zwarte circuit. De inkoop van spullen, op afbetaling gekocht, spullen die gestolen zijn die je dan voor de halve prijs kan kopen, waar je ook bonnetjes voor kan tekenen. Deze schulden, daar krijg je heel moeilijk vat op. Deze schulden, daar ligt de zwaarte in afrekening” (Resp. R2).

Schrijer benadrukt dat deze schuldenproblematiek bovendien door alle opleidingslagen heen loopt. 
"En wat met name schokkend is dat goeie Antillianen, die in potentie de mogelijkheid hebben zich daaraan te onttrekken, er toch met name via de schuldenproblematiek en intimidatieproblematiek weer ingezogen worden. Gedwongen worden om in het criminele circuit toch hand-en spandiensten te verrichten, door dat systeem van lenen en schulden over en weer in de eigen groep" (Resp. R8).

\section{Bovenmatige concentratie van problemen}

Van alle bovengenoemde problemen maakt niet één specifiek probleem, maar juist de concentratie van velerlei problemen dat bepaalde delen van Charlois in een neerwaartse spiraal terecht zijn gekomen. Dominic Schrijer zegt hierover:

“Op een gegeven moment gaat alles rood doordat er te lang niet is ingegrepen. Dan heb je drugs, kamerverhuur, een winkelcentrum wat weg is, een of twee scholen die slecht functioneren, te veel ellende bij elkaar." Dit is ook de reden voor zijn pleidooi voor een stop op de komst van nog meer kansarme groepen naar Charlois: "We willen niet dat er een concentratie komt van kansarme mensen met weinig geld, grote problemen, werkloosheid, laag inkomen. (...) Dat zijn namelijk van die indicatoren; als er te veel mensen zijn die slecht scoren op het gebied van laag inkomen, eenoudergezin, geen werk, uitkering, slechte taalbeheersing. Als dat bij elkaar woont, dat is vragen om problemen. En dan kan je ze stimuleren, opleiden, en coachen wat je wil, maar of het zal helpen (...)” (Resp. R8).

\subsection{DISCUSSIE}

In de Tarwewijk spelen er veel problemen op het gebied van leefbaarheid en veiligheid die in sterke mate gerelateerd zijn aan de kenmerken van de woningvoorraad en woningmarkt in de wijk. Overlast van drugspanden, prostitutie, hanggroepjongeren, vervuiling van de straat et cetera, maken dat veel bewoners ontevreden zijn met hun buurt waardoor zij deze na korte tijd de rug toekeren. Het relatief hoge aantal verhuizingen gaat ten koste van de sociale cohesie.

Was de Tarwewijk oorspronkelijk een buurtje voor arbeiders die werkten in de haven of aanverwante bedrijven waar de buurtbewoners elkaar kenden, de laatste decennia is het een buurt geworden waar veel migranten, mensen met een laag inkomen of uitkering, illegalen, drugsgebruikers, dealers et cetera zich hebben gevestigd. Door deze variëteit in achtergronden in de buurt is het moeilijk sociale cohesie te creëren en is er in sommige gevallen een gebrek aan sociaal kapitaal. Er is sprake van geringe banden (bonding) tussen de buurtbewoners, waarmee bedoeld wordt dat er slechts in beperkte mate onderlinge ondersteuning is in de vorm van netwerken van lotgenoten. Ook zijn bewoners niet in staat bruggen te slaan naar andere sociale groepen (bridging) waardoor hun sociaal isolement wordt bestendigd (Engbersen 2003). 
Naast de leefbaarheidsproblemen en de gebrekkige sociale cohesie is de onveiligheid een ander veelgenoemd probleem. De omvang van het veiligheidsprobleem verschilt echter wanneer we ons op verschillende bronnen baseren. Wanneer wij de Veiligheidsindex als uitgangspunt nemen is de Tarwewijk de op drie na onveiligste wijk van Rotterdam. De Veiligheidsindex is gebaseerd op objectieve gegevens en resultaten uit een veiligheidsenquête die gehouden is onder bewoners.

De Tarwewijk scoort hier laag op en wat verder opvalt is dat de veiligheidssituatie in zowel heel Rotterdam en in de deelgemeente Charlois tussen 2001 en 2003 enigszins is verbeterd, maar dat dit niet geldt voor de Tarwewijk. Wanneer we het aantal delicten dat bij de politie bekend is als uitgangspunt nemen, lijkt de onveiligheid relatief minder groot. Het aantal delicten in de Tarwewijk ligt verhoudingsgewijs lager dan in heel Charlois en heel Rotterdam. Bovendien is het aantal delicten per duizend inwoners in de wijk enorm teruggelopen, met name het aantal delicten op het gebied van veiligheid zoals diefstal en inbraak in woning, diefstal van en uit auto's, zakkenrollerij, maar ook geweldsdelicten zoals geweld tegen personen, bedreiging, mishandeling, straatroof en overvallen. De gemeente vindt de veiligheidssituatie in ieder geval dermate ernstig dat zij drie zogenaamde hotspot-gebieden in de wijk heeft aangewezen, waarin zij extra maatregelingen neemt ter bestrijding van de onveiligheid.

Kenmerkend voor de Tarwewijk is ook de specifieke woningvoorraad. Een achterstandswijk als de Tarwewijk trekt door de lage huurprijzen veel laaggeschoolden, uitkeringsgerechtigden, lage inkomensgroepen en minderheden aan. De lage huurprijzen in samenhang met het grote aandeel woningen in particulier bezit ( $43 \%$ van de totale woningvoorraad) en de vele leegstaande panden, maken het bovendien een aantrekkelijke locatie voor drugsgebruikers, dealers, kleine criminelen en illegale vreemdelingen - met andere woorden voor iedereen die aangewezen is op het 'souterrain van de stedelijke woningmarkt'. De particuliere woningbezitters verhuren hun woningen vaak per kamer of soms zelfs per bed aan illegalen, wat vaak overlast veroorzaakt voor omwonenden, omdat er veel personen op één adres wonen (vgl. Leerkes et al. 2004).

De grote leegstand wordt mede veroorzaakt door de slechte woningmarkt in de Tarwewijk, waardoor het voor kopers een te groot risico vormt om een pand te kopen en op te knappen. De leegstaande woningen trekken junks, zwervers en illegalen aan, wat bovendien versterkt werd door maatregelingen van de gemeente Rotterdam om deze groepen uit het centrum te weren. Het leegstaan van panden heeft een zichzelf versterkende werking: naarmate meer panden leegstaan in een straat, wordt het minder aantrekkelijk om er te wonen, waardoor er meer mensen verhuizen en er zich minder mensen zullen vestigen, waardoor er uiteindelijk weer meer panden leeg komen te staan. Daarnaast vormde met name eind jaren negentig 'redlining' een probleem voor de mensen die toch een woning wilden kopen in de Tarwewijk. Banken wilden niet of nauwelijks hypotheken verstrekken voor woningen in bijvoorbeeld de Millinxbuurt, omdat ze vreesden dat de woningprijzen er verder zouden zakken waardoor kopers mogelijkerwijs de hypotheek niet konden aflossen. 
Veel van bovengeschetste problemen waren in eerste instantie alleen zichtbaar in een deel van de Tarwewijk, namelijk in de Millinxbuurt. Inmiddels lijken de omringende buurten te kampen met een spillover-effect. Problemen als criminaliteit en drugsoverlast verplaatsen zich ten dele van de Millinxbuurt naar de aangrenzende buurten (Botman en van Kempen 2001). Ondanks alle problemen in de Tarwewijk is deze wijk pas in 1999 door de gemeente aangewezen als gebied voor het grotestedenbeleid. Het doel van de stedelijke herstructurering die nu in gang is gezet, is om meer variatie in de woningvoorraad te krijgen waarbij ingezet wordt om de bewoners die er wonen te behouden. Het is moeilijk om dit alles op korte termijn te realiseren. Er zijn immers vele particuliere eigenaren waarmee een regeling getroffen moet worden voordat met een herstructurering aangevangen kan worden. In afwachting van een herstructurering worden veel woningen verwaarloosd, omdat investeren immers niet meer rendabel lijkt, waardoor de buurt (tijdelijk) nog meer dreigt te vervallen.

Een ander aspect waar we in de buurten van ons onderzoek naar hebben gekeken is onderwijs. De toekomstkansen van de jonge bewoners hangen immers voor een groot deel af van het niveau dat bereikt wordt op de basisschool en middelbare school. Bij de basisscholen hebben we gekeken naar het aantal achterstandsleerlingen en de behaalde Cito-scores. De scholen in de Tarwewijk hebben relatief veel leerlingen met ouders met een laag opleidings- of beroepsniveau en/of een etnische herkomst en behalen een iets lagere gemiddelde Cito-score dan scholen met een vergelijkbaar aantal achterstandsleerlingen elders in Rotterdam en in Nederland. De kansen voor kinderen in de basisschoolleeftijd in de Tarwewijk lijken dus iets minder gunstig dan elders in de stad en in Nederland te liggen. Wat betreft het middelbaar onderwijs hebben we gekeken naar de voortijdige schooluitval, het absoluut en relatief verzuim en het aantal bemiddelingen. Charlois heeft in vergelijking met de andere deelgemeenten van Rotterdam in een zeer hoge mate te kampen met voortijdig schooluitval, spijbelen (relatief verzuim), überhaupt niet naar school gaan (absoluut verzuim) en problematische situaties tussen school, ouder en kind waar een leerplichtambtenaar in actie moet komen (bemiddelingen). Dit alles vormt een risico voor de arbeidsmarktkansen van de 16-23-jarigen uit Charlois.

Het vierde aspect waarop we de Tarwewijk en Charlois hebben bekeken is de hoogte van de werkloosheid en de uitkeringsafhankelijkheid. Een fundamenteel probleem in de Tarwewijk vormt het hoge aantal bijstandsontvangers. Er zijn geen gegevens beschikbaar van het aantal werkenden en werklozen in specifiek de Tarwewijk, maar voor Charlois geldt dat de werkloosheid groot is, maar dat deze niet veel afwijkt van het stedelijke gemiddelde. Wat verder opvallend is voor de Tarwewijk is het hoge aantal gezinnen dat rond moet komen van een laag inkomen.

Een deel van de werkloosheid is volgens onze respondenten te wijten aan het feit dat sommige bewoners niet aan basisvoorwaarden als lezen en schrijven voldoen. Daarnaast hebben sommige groepen, bijvoorbeeld Antillianen, een onrealistisch beroepsbeeld. Voor de dienst Sociale Zaken en Werkgelegenheid vormt boven- 
dien de hoge mutatiegraad van de jongeren die een uitkering hebben een probleem bij de bestrijding van de werkloosheid.

Naast bovengenoemde problemen spelen ook andere zaken een rol. Onjuiste gegevens en een gebrekkige administratie van gemeentelijke instellingen zorgen dat de uitvoering van instellingen die afhankelijk zijn van die gegevens in sommige gevallen moeizaam, inefficiënt en ineffectief verloopt. Daarnaast kent Charlois een grote groep risicojongeren, waarvan een aanzienlijk deel van Antilliaanse afkomst is. Het overlast gevend gedrag blijkt vaak voort te komen uit problematische situaties thuis. Andere problemen die spelen binnen de Antilliaanse gemeenschap zijn de hoge aantallen jonge alleenstaande moeders en een schuldenproblematiek, waardoor men in sommige gevallen overgaat tot criminele activiteiten.

Van alle bovengenoemde problemen maakt niet één specifiek probleem, maar juist de concentratie van velerlei problemen dat bepaalde delen van Charlois, waaronder de Tarwewijk, in een neerwaartse spiraal terecht zijn gekomen. 


\section{NOTEN}

I De deelgemeente Charlois bestaat uit de wijken: Tarwewijk (buurtnummer 71), Carnisse (72), Zuidwijk (73), Oud Charlois (74), Wielewaal (75), Zuidplein (76), Pendrecht (77), Zuiderpark (78), Heijplaat (93).

2 Gegevens: Gemeente Rotterdam, cos.

3 Deelgemeente Charlois. http://www.deelgemeenten.rotterdam.nl/.

4 Resp. R8: Dagelijks bestuurder deelgemeente Charlois, portefeuillehouder Ruimtelijke Ontwikkeling, Beheer \& Wijkzaken. Gegevens: Gemeente Rotterdam (2004) Veiligheidsindex 2004. Meting van de veiligheid in Rotterdam. Rotterdam: Gemeente Rotterdam.

6 De Veiligheidsindex is samengesteld uit een groot aantal gegevens, zowel feitelijke gegevens als bewonersoordelen. Cijfers over het aantal aangiften en meldingen, ervaren buurtproblemen, slachtofferschap, maar ook omgevingskenmerken als het gemiddelde inkomen en verhuisbewegingen vormen tezamen de Veiligheidsindex. De Veiligheidsindex geeft voor de hele stad en alle wijken in de stad een rapportcijfer. Het rapportcijfer loopt van 1 (onveilig) tot 10 (veilig). Er zijn vijf categorieën te typeren: onveilig (score lager dan 3,9), probleem (score van 3,9 tot 5,0 ), bedreigd (score van 5,0 tot 6,0 ), aandacht (score van 6,o tot 7,1 ) en (redelijk) veilig (score van 7,1 of hoger).

Geciteerd in Desmet et al. 2003.

8 Resp. R7: Buurtbewoner, buurtconciërge, Charlois.

9 Een bewoner uit de Millinxbuurt, citaat uit Desmet et al. 2003.

10 Resp. R5: Laanmanager en projectleider interventieteams, Charlois.

11 Resp. R3: Directeur Transfer Informatie Punt, Charlois.

12 Een bewoner uit de Millinxbuurt, geciteerd in Desmet et al. 2003.

13 Gegevens: N.D. Verhelst, (2003), Resultaten van de Rotterdamse scholen op de Eindtoets Basisonderwijs 2003.

14 Resp. Rio: Adjunct-directeur basisschool De Beatrixschool.

15 Interview Resp. R1: Hoofd Sociale Wetenschappelijke afdeling Dienst Sociale Zaken Rotterdam. Interview Resp. R6: Buurtbewoner Charlois, gemeenteraadslid (PvdA) Rotterdam.

16 Interview Resp. R6; Gemeente Rotterdam, Voorjaarsnota 2004. Rotterdam: Gemeente Rotterdam.

17 Resp. R2: Directeur Stichting WelzijnsBevordering Antillianen/Arubanen.

18 Informatieflyer TIP 2004. 


\section{DE HERONTDEKKING VAN DE TARWEWIJK}

\subsection{INLEIDING}

In het voorbije jaar heeft de Rotterdamse aanpak van stedelijke vraagstukken veel aandacht gekregen en veel stof doen opwaaien. Het gedachtegoed van het huidige college is neergelegd in het Collegeprogramma 2002-2006 Het nieuwe elan van Rotterdam... En zo gaan we het doen (2002) en in de latere nota Rotterdam zet door. Op weg naar een stad in balans (2003). In deze laatste nota wordt mede gereageerd op het rapport Bevolkingsprognose Rotterdam 2017 van het Centrum voor Onderzoek en Statistiek (COS) over de bevolkingsontwikkeling in Rotterdam. Kern van deze nota is dat de komende jaren het aantal autochtone Rotterdammers verder zal afnemen en dat er een grote toename zal zijn van het aantal mensen uit de Antillen en 'overige arme landen'. Het gevolg daarvan zal zijn dat in 2017 bijna de helft van Rotterdamse bevolking zal bestaan uit Surinamers, Antillianen, Kaapverdianen, Turken, Marokkanen en overige 'arme landen'.

In het rapport Rotterdam zet door. Op weg naar een stad in balans worden voorstellen gepresenteerd om tot een meer evenwichtige samenlevingsopbouw te komen. Belangrijk elementen daarin zijn het voeren van een selectief vestigingsbeleid (in samenwerking met het rijk) en het realiseren van een regionaal huisvestingsbeleid voor kansarme groepen (in samenwerking met de randgemeenten).

Voordat het huidige Rotterdamse college met het rapport Rotterdam zet door beleidsmatig reageerde op de geschetste demografische ontwikkelingen van Rotterdam, had een 'noodkreet uit de lokale praktijk' geklonken. Dominic Schrijer, wethouder van de deelgemeente Charlois, wees er met klem op dat een blijvende toestroom van kansarmen de draagkracht van zijn deelgemeente verre te boven ging. Hij pleitte derhalve voor een eerlijker spreiding van kansarme bewoners over stad, regio en land. Ook zijn voorstellen en de actuele aanpak in de deelgemeente Charlois komen in dit hoofdstuk kort aan de orde

Eerst gaan we in op recente ontwikkelingen in het denken over de stad en de sociale vragen waarmee de stad Rotterdam wordt geconfronteerd (paragraaf 5.2). Vervolgens gaan we nader in op de kenmerken van de Rotterdamse aanpak, zoals die zichtbaar wordt in de Tarwewijk in de deelgemeente Charlois (paragraaf 5.3).

\subsection{VAN 'NIEUW ROTTERDAM' NAAR 'ROTTERDAM IN BALANS'}

In 1987 verscheen het rapport Nieuw Rotterdam (1987) van de Adviescommissie Sociaal-Economische Vernieuwing Rotterdam (ook wel commissie-Albeda genoemd). In dit rapport werd een visie gepresenteerd over de toekomst van de Rotterdamse economie. Het interessante van dit rapport was dat de rapporteur van deze commissie Pim Fortuyn was die 15 jaar later verantwoordelijk zou zijn 
voor het politieke succes van Leefbaar Rotterdam bij de gemeenteraadsverkiezingen in Rotterdam in 2002. In het rapport van de commissie-Albeda werd een groot aantal voorstellen gedaan om de Rotterdamse economie te vernieuwen en de stedelijke werkloosheid te bestrijden. De Rotterdams haven zou moeten uitgroeien van een overslag naar een hightechwereldhaven. Er zou meer aandacht moeten komen voor het midden- en kleinbedrijf. Ook zou moeten worden nagedacht over de ontwikkelingen bij verzekeringsbedrijven en banken, de rol van kennis en technologie, de ontwikkeling van Rotterdam Airport en het bestrijden van de werkloosheid. Ten slotte werden voorstellen gedaan om de culturele positie van Rotterdam te versterken.

Een jaar later zal als aanvulling het rapport Het nieuwe Rotterdam in sociaal perspectief (1989) verschijnen van de Commissie Sociale Vernieuwing (ook wel commissie-Idenburg genoemd). In de verantwoording van haar rapport schrijft de commissie-Idenburg dat zij vier belangrijke overtuigingen heeft, namelijk dat: (1) economische en sociale vernieuwing samengaan; (2) sociale vernieuwing alle Rotterdammers raakt, (3) sociale vernieuwing een zaak is van de lokale gemeenschap en niet van 'Den Haag' en (4) de sleutel tot sociale vernieuwing gezocht moet worden in de herijking en herverdeling van verantwoordelijkheden van burger, stedelijke gemeenschap en de overheid. Wat sociale vernieuwing precies behelst bleef overigens nogal vaag (vgl. Schuyt 1991). Het rapport over de sociale vernieuwing heeft niettemin de nodige invloed gehad in en buiten Rotterdam als het gaat om het ontwikkelen van projecten die vanuit bewoners worden opgezet om de leefbaarheid in buurten te vergroten. Het archetypische voorbeeld van sociale vernieuwing in Rotterdam werd het Opzoomeren, waarbij burgers zelf bijdragen aan de leefbaarheid en veiligheid van hun straat (Duyvendak en Van der Graaf 2001) .

Ook de ideeënontwikkeling rond het rapport Nieuw Rotterdam heeft zijn invloed gehad, bijvoorbeeld in de planvorming over de haven, de ontwikkeling van grote economische en culturele projecten en de vormgeving van de nieuwe skyline van Rotterdam. De stedelijke innovaties die daaruit zijn voortgekomen worden door bezoekers van buiten gewaardeerd. Het jaar 2003 bleek voor Rotterdam een topjaar met ruim 17 miljoen bezoekers. De Rotterdamse podia en musea trokken meer bezoekers en dat geldt ook voor jaarlijkse festivals en evenementen. In deze cijfers kan men een voorzichtige rechtvaardiging zien van wat in 2001 een opmerkelijke uitverkiezing leek: Rotterdam als een culturele hoofdstad van Europa. Opvallend in de oudere rapporten is - en dat geldt overigens ook voor het programma waarmee Rotterdam zich presenteerde als culturele hoofdstad van Europa - het relatief positieve zelfbeeld van een dynamische, multiculturele stad. In het rapport Nieuw Rotterdam werd zelfs het idee geopperd om voor de 35.0oo islamieten in Rotterdam een kasba te bouwen die tevens dienst zou kunnen doen als toeristische trekpleister.

De rapporten Nieuw Rotterdam en Het nieuwe Rotterdam in sociaal perspectief zijn typerend voor hun tijd: er worden grootse en meeslepende visies ontvouwd en nieuwe beleidsbegrippen geïntroduceerd. Er is ook veel aandacht voor het 
bestrijden van de langdurige werkloosheid die eind jaren tachtig omvangrijke proporties heeft aangenomen. ${ }^{1}$ Tevens is er de nodige aandacht voor de ruimtelijke concentratie en achterstand van allochtone groepen, maar is er weinig aandacht voor de alledaagse problemen van leefbaarheid en integratie en voor de grimmige kanten van een arme, multiculturele samenleving die zowel economisch als demografisch razendsnel van karakter verandert.

Wie de recente nota's Het nieuwe elan van Rotterdam (2002) en Rotterdam zet door (2003) doorneemt treft een heel andere toonzetting aan. Het visionaire economische perspectief van Nieuw Rotterdam is afwezig, evenals het abstracte sociaal-wetenschappelijke idioom van Het Nieuwe Rotterdam in sociaal perspectief. Wel probeert Rotterdam via de oprichting van een Economic Development Board Rotterdam (EDBR) strategisch aandacht te besteden aan structuurveranderingen binnen de Rotterdamse grootstedelijke economie. In de bovengenoemde rapporten is er echter vooral veel aandacht voor alledaagse problemen van veiligheid, integratie en sociale verbondenheid en wordt een dwingend beleid voorgesteld om de stedelijke sociale problemen het hoofd te bieden. Het beleid kan in de eerste plaats gezien worden als een poging om de eigen stad weer te herontdekken en te heroveren. Daarbij wordt een sterk accent gelegd op de uitvoering en doelmatigheid van het beleid. Vandaar ook het formuleren van collegedoelstellingen waarop men afgerekend wil worden. Opvallend is verder dat een beroep wordt gedaan op andere partijen en hogere schaalniveaus (rijk en regio) om de Rotterdamse problematiek het hoofd te bieden. De zienswijze zoals die verwoord stond in de nota Het nieuwe Rotterdam in sociaal perspectief (1989) dat vernieuwing van de stad vooral een 'lokale aangelegenheid' is, wordt radicaal opzijgezet. Men wil in samenspraak met het rijk een selectief vestigingsbeleid ontwikkelen dat het mogelijk moet maken om (inkomens)eisen te stellen aan woningzoekenden van buiten de regio Rotterdam. Een ander kernpunt is het tot stand brengen van een regionaal huisvestingsbeleid om zodoende tot een meer evenwichtige spreiding te komen van kansarme groepen (waaronder asielzoekers en migranten die vanwege gezinsvorming hier naar toe zijn gekomen).

\subsection{DE HERONTDEKKING EN HEROVERING VAN DE TARWEWIJK}

In hoofdstuk 4 is een schets gegeven van de sociale structuur en problemen van de Tarwewijk. Deze problemen maken duidelijk hoe zeer de in hoofdstuk 2 geschetste sociaal-structurele processen hun weerslag hebben op de deelgemeente Charlois en de Tarwewijk. Het nieuwe sociale beleid richt zich in het bijzonder op het vergroten van de leefbaarheid en veiligheid van de wijk en, als onderdeel daarvan, op het veranderen en verbeteren van de woningvoorraad.

Het beleid in Charlois kan worden geduid met het begrip 'sociale herovering': het is een poging om onrechtmatige praktijken terug te dringen, de leefbaarheid en veiligheid in de publieke ruimte te vergroten en tot een meer evenwichtige samenlevingsopbouw te komen. Daarbij poogt men aan te sluiten bij het specifieke karakter en de specifieke ligging van deze stedelijke 'buitenwijk'. De aanpak 
in Charlois is een weerspiegeling van de planvorming zoals die wordt ontwikkeld op het gemeentehuis. De motiveringen die ten grondslag liggen aan diverse projecten zijn soms anders dan die van het Rotterdamse college, maar in de uitwerking zien we dat er een grote overeenkomst bestaat over de aard en prioriteiten van de aanpak. Overigens dient te worden benadrukt dat een aantal initiatieven zoals ze in deze paragraaf worden beschreven al waren ontwikkeld voordat het nieuwe college in Rotterdam aantrad. Dat geldt bijvoorbeeld voor de 'interventieteams'. Wel zijn dergelijke initiatieven door het huidige college geïntensiveerd.

\subsubsection{HET TRANSPARANT MAKEN VAN DE WIJK}

Een eerste kenmerk van aanpak in de Tarwewijk is het transparant maken van de wijk. In de jaren tachtig en negentig zijn diverse informele en onrechtmatige praktijken gegroeid, naast allerlei vormen van verloedering van publieke ruimten, die nu krachtig worden aangepakt. Het gaat om zaken als drugsoverlast, hanggroepjongeren, onrechtmatige bewoning (overbewoning, bewoning door illegalen, etc.), graffiti, overlast gevende horeca, belwinkels, hennepkwekerijen, rattenplagen, verwaarloosde achtertuinen tot het tegengaan van schooluitval. Veel (semi-)publieke instellingen die in direct contact staan met bewoners hebben zich in de loop van de jaren tachtig en negentig ontwikkeld tot street-level bureaucratieën die sterk naar binnen waren gericht en zich deels afschermden van het publiek en de straat. Met bewoners en klanten werden vooral administratieve en bureaucratische relaties onderhouden.

Een eenvoudig voorbeeld is de Rotterdamse Sociale Dienst die tot op heden niet in staat is om huisbezoeken af te leggen bij al haar Rotterdamse bijstandsklanten. Hetzelfde geldt voor veel woningbouwcorporaties, scholen, politie-instellingen en zelfs buurtverenigingen. Middelenproblemen spelen overigens een belangrijke rol in dit sociale terugtrekgedrag van instellingen. Die situatie is veranderd. Street-level bureaucratieën ontwikkelen steeds meer een street-level beleid om alledaagse problemen te bestrijden en de relaties met bewoners, ouders, jongeren, uitkeringsgerechtigden weer te herstellen. Het street-level beleid in de deelgemeente Charlois krijgt gestalte in het op orde krijgen van relevante 'databestanden' van bewoners en uitkeringsgerechtigden en in nieuwe beroepen als buurtconciërges, stadsmariniers en laanmanagers. Ook zien we de inzet van interventieteams die hotspot-gebieden aanpakken, of het optreden van gastvrouwen die in ouderkamers een brug proberen te slaan tussen de school en allochtone ouders.

\section{De buurtconciërge}

Leo Pas woont al 23 jaar in de Tarwewijk. Vanaf 1998 ziet hij de Millinxbuurt verpauperen. Er komen steeds meer panden leeg te staan, die opengebroken worden door drugsgebruikers en die er een puinhoop van maken. Als bewoner ergert hij zich hieraan. Hij besluit de panden te gaan controleren, door elke dag een ronde te lopen, rapportages te maken en de politie te bellen. Hij zit 
op dat moment in de WAO. Hij wil 'een pandenbeheer' in de Millinxbuurt oprichten. De deelgemeente waardeert het initiatief en stelt Leo Pas aan als een zogenaamde buurtconciërge die betaald wordt vanuit de Werkmaatschappij Charlois, en later door stichting Omij. De leegstaande panden worden in eerste instantie met hout afgesloten, maar doordat dit makkelijk blijkt open te breken worden er sinds een paar jaar stalen deuren geplaatst.

Wanneer er een stadsmarinier wordt aangesteld in de buurt besluit deze om ook een buurtconciërge op Zuidplein aan te stellen. Inmiddels zijn er in totaal 5 buurtconciërges: in de Tarwewijk, Pendrecht, Zuidplein één en in Oud-Charlois twee. Leo Pas is nu overgeplaatst naar Carnisse om daar ook als buurtconciërge te beginnen (zijn functie in de Tarwewijk wordt overgenomen door een nieuwe buurtconciërge).

Een buurtconciërge houdt zich met name bezig met het fysieke aspect van de buurt: de straat, het trottoir, de vuilnisbakken, controle van achtertuinen. Als er sprake is van overbewoning, dan speelt hij dat weer door aan de deelgemeente of aan de interventieteams. Tevens is een buurtconciërge een aanspreekpunt voor de bewoners. "Je neemt contact op met bewoners en als mensen vragen hebben moet je die beantwoorden, of moet je ze doorsturen naar de juiste instantie. Je bent eigenlijk een hulpverlener voor de hele wijk (...). Als buurtconciërge moet je goed aanspreekbaar zijn, ook voor problemen (...). Sommige mensen durven niet naar de politie. Waar kan je dan het beste mee praten: met een buurtconciërge. Je bouwt een vertrouwensband op met alle mensen die hier wonen. Dan gaan ze je vertrouwen en dan gaan ze meer dingen vragen, om hulp vragen en dan stuur je ze gewoon door."

\section{De laanmanager}

Op de Dordtselaan is een laanmanager werkzaam die de opdracht heeft de laan schoner, heler, veiliger en socialer te maken. Dit wordt gedaan in samenwerking met een aantal belangrijke partners als de politie, de Gemeente Reinigingsdienst, Roteb, Gemeentewerken, stadstoezicht, de Sociale Dienst en de deelgemeente. "We zijn bezig met die vier thema's schoon, heel, veilig en sociaal. En schoon en heel zien er goed uit. In veilig zijn we nu nog aan het investeren, maar in een periode van een maand of 6 à 7 heb ik dus zo'n dertig illegale pensions gesloten en een aantal bedrijfsruimtes ingehuurd waar we goede ondernemers voor zoeken. We hebben op de veiling een aantal overlast gevende appartementen ingekocht in samenwerking met het Wijk Ontwikkelings Maatschappij. We hebben het 'broken windows' project gedraaid met bouw en woningtoezicht, waarbij alle gevels zeer nauwkeurig geïnspecteerd en hersteld zijn, dus het vervangen van de ramen en dat soort zaken. We hebben een rattenproject gedraaid in samenwerking met een aantal bewoners. We hebben een bewonerspanel ingesteld. Dat is een groep mensen van de Dordtselaan die een keer per twee maanden bij elkaar komt en waarmee we een aantal thema's bespreken. Gisteren hebben we toevallig zo'n bijeenkomst gehad waar dan ook Dick Lockhorst van de deelgemeente aanwezig is, de stadsmarinier en zo'n 20, 25 bewoners en ondernemers. Gisteren was het thema veiligheid. De politie heeft een uitleg gegeven: van nou die extra inzet van ons zit zo en zo in elkaar en merken jullie daar nou wat van? Dus dan praat je daar op een positieve en leuke manier over met bewoners" (Resp. R5).

Daarnaast zien we dat ideeën die veel eerder ontwikkeld zijn in het kader van Sociale Vernieuwing, de Brede School of het grotestedenbeleid meer en meer handen en voeten krijgen. Het herontdekken van de stad gaat gepaard met een 
toenemende praktische wijsheid en regelconform handelen van publieke en private diensten en organisaties. Sociale diensten hebben eerder in de gaten dat groepen geen recht op een uitkering hebben, het jongerenwerk weet Antilliaanse probleemgroepen te bereiken en in het gareel te houden en interventieteams slagen erin om illegale bewoning terug te dringen.

Opvallend is ook de herpositionering van traditionele bewonersorganisaties. In de Tarwewijk gaat de 'Bewonersorganisatie Tarwewijk' (вот) zich omvormen tot een 'organisatie van en door bewoners' (OvdB). De bewonersvereniging nieuwe stijl zal daarom 'OvdB Tarwewijk' gaan heten. Ook traditionele buurt-organisaties dienen nadrukkelijker dan voorheen hun buurtbasis te versterken om niet aan legitimiteit te verliezen bij de bewoners.

Naast de deelgemeente, politie, woningcorporaties, scholen en bewonersorganisaties nemen bewoners zelf ook initiatieven om de buurt meer transparant te maken. Er wordt gepoogd bruggen te slaan tussen de bewoners in de wijk en de sociale cohesie te vergroten door bijvoorbeeld een initiatief als de Vereniging Millinxtheater. Ook wordt getracht om de afstand tussen bewoners en de politiek kleiner te maken door een initiatief als de Jongerenantennes. Een aantal jongeren is hierbij aangewezen als antenne en zij vormen een schakel tussen de jongeren onderling en tussen de jongeren en de politiek. De antennes brengen wensen, meningen en ideeën van de jongeren uit de wijk onder de aandacht van de deelgemeente en toetsen de ideeën van de politiek bij de jongeren uit de wijk, zodat ook voor de politiek inzichtelijk is wat de jongeren wel en niet willen. Ook worden zij betrokken bij discussies over de toekomst van de wijk.

\section{De Vereniging Millinxtheater}

De Vereniging Millinxtheater is opgericht op 1 mei 2001 na het spelen van de Millinxsoap. Deze soap was bedoeld als uitlaatklep voor de bewoners. De bewoners konden hun verhaal over het leven in de Millinxbuurt middels toneelspelen overbrengen aan medebewoners en professionals, zonder dat zij onderbroken konden worden. Een ander doel hiervan was dat bewoners elkaar en de buurt via deze soap beter leerden kennen.

Vanaf januari 2002 komt er elke donderdagavond een toneelgroep bijeen in het Cultuurhuis voor toneellessen. De toneelstukken gaan met name over de Millinxbuurt. De Vereniging Millinxtheater streeft door middel van allerlei culturele activiteiten het leefklimaat in de buurt te verbeteren. Het motto van het Cultuurhuis is dan ook "voor bewoners, door bewoners". Behalve toneelspelen heeft de vereniging allerlei culturele feesten georganiseerd, zoals het suikerfeest en thema-avonden als het paasfeest en een spelletjesavond. Ook zijn er plannen voor allerlei cursussen in houtbewerking, schilderen en fotolessen.

\subsubsection{BUURTINTERVENTIES}

In de deelgemeente Charlois keren de trias 'repressief, normerend en interventies in de privé-sfeer' ook terug. De krijgsmetaforen van stadsmariniers, hotspot-gebieden, interventieteams maken duidelijk dat bepaalde sociale ruimten heroverd moeten worden. Er is een zwaardere inzet van politie en een hardere aanpak van 
regelovertreders in geval van forse wijkproblemen. Er worden stalen deuren geplaatst om de toegang tot overlast gevende panden te blokkeren en huisjesmelkers worden snel en streng beboet. Ook wordt in sommige gevallen overgegaan tot preventief fouilleren. In de periode oktober 2002 tot december 2002 is de Tarwewijk als 'veiligheidsrisicogebied' aangewezen waardoor de officier van justitie in die periode kon gelasten om verpakkingen van goederen, met inbegrip van reisbagage, te openen, vervoermiddelen te onderzoeken en eenieder aan de kleding te onderzoeken op wapens en munitie.

\section{Stadsmariniers}

In Rotterdam is een zogenaamd mariniersmodel ingesteld. In vier gebieden, te weten Centrum/ Centraal Station, Feijenoord, Delfshaven en Charlois, zijn vijf stadsmariniers aangesteld om de veiligheid in de stad te vergroten. Deze ambtenaren dienen de smeerolie te zijn tussen de partijen die verantwoordelijk zijn voor de uitvoering van de projecten ten behoeve van de veiligheid in een gebied, zoals tussen gemeente, politie, justitie en andere instanties. Bovendien moeten de stadsmariniers de voortgang en de uitvoering van de targets bewaken in 'onveilige gebieden'² en 'hotspots'3. Het einddoel is om eind 2005 geen onveilige wijken meer te hebben in Rotterdam. 4 De stadsmarinier kan volgens Belderbos (de stadsmarinier die gestationeerd is in Charlois) het volgende toevoegen aan alle inzet die al op de laan wordt gepleegd: "De stadsmariniers worden afgerekend op concrete resultaten, op uitvoering. Dat is nieuw. De inzet van verschillende diensten kan gerichter en de samenwerking is nog niet optimaal. Daarom is het goed afstemmen van de uitvoering tussen verschillende diensten cruciaal. En dat is met name het surplus dat de stadsmariniers moeten leveren."5

De stadsmarinier is weer opdrachtgever van de laanmanager.

\section{Hotspot-gebieden 6}

Hotspot-gebieden zijn gebieden waar criminaliteit, vervuiling en verloedering het beeld bepalen en veiligheid ver te zoeken is/was. In 2002 zijn er negen hotspots aangewezen die in de periode 2003 2008 moeten worden aangepakt. Het gaat om gebieden in de deelgemeenten Charlois, Feijenoord en Delfshaven. Voor de aanpak van de negen hotspots heeft de gemeente een bedrag van bijna 33 miljoen euro beschikbaar gesteld. Dit budget wordt via het programma 'Hot Spots' ingezet.

De gemeente investeert er extra in achterstallig onderhoud aan panden en aan de buitenruimte. In samenwerking met verschillende ((deel)gemeentelijke) diensten, eigenaren, corporaties e.d. worden panden opgeknapt, aangekocht, gesloopt en nieuw gebouwd. Naast de fysieke aanpak is er ook een sociale en economische aanpak van de hotspots. Er komen bijvoorbeeld betere voorzieningen op het gebied van educatie, kunst, sport en recreatie.

De stadsmariniers vervullen een regiefunctie binnen de hotspot-gebieden. In de Tarwewijk zijn er drie hotspotgebieden aangewezen, te weten de Dordtselaan, de Bas Jungeriusstraat en de Katendrechtse Lagendijk.

\section{Interventieteams ${ }^{7}$}

De interventieteams werden als eerste actief op de Dordtselaan. Daar begon de 'sociale ellende' met overbewoning en onrechtmatige bewoning wat veel geluids- en criminaliteitsoverlast gaf 
voor de omwonenden. Het interventieteam begon met het systematisch in kaart brengen en in de gaten gehouden van alle panden, eerst op de Dordtselaan, later ook in de Millinxbuurt. Het team werd bemand met een medewerker van bouw- en woningtoezicht, van de sociale dienst, van de afdeling openbare orde en veiligheid van de deelgemeente Charlois, een politieagent en de zorgcoördinator van de buurt. Geholpen door meldingen van geluidsoverlast op de klachtenmeldlijn, en gewapend met betrouwbare vermoedens van illegale verhuur, klopte het team aan op verdachte deuren. Het hoefde geen geweld te gebruiken, het 'belde gewoon aan'. In 99 procent van de gevallen werd de deur gewoon opengedaan.

Wanneer het team achter de deur 'onregelmatigheden' aantrof, zoals opgesplitste kamertjes, dan werd de huiseigenaar in staat gesteld de woning (dikwijls huur) binnen twee maanden in de oude staat terug te brengen en in de normale verhuur aan een gezin te doen. Als vervolgens bij een herbezoek bleek dat er niets was gebeurd, en hij ook weigerde voor een gesprek te verschijnen, dan werd een stalen deur geplaatst, die een jaar op z'n plaats bleef, en de huisjesmelker pardoes afsneed van zijn lucratieve inkomen.

Met de onwrikbare, stalen deur hield het niet op. De voorzitter van deelgemeente Charlois dhr. Lockhorst zegt hierover: "Die deur wordt aangebracht op grond van de burgemeestersluiting (artikel 174a van de Gemeentewet). De basis is herhaalde (drugs)overlast, maar wij passen dit dus óók toe voor overlast door overbewoning. Daarnaast krijgt de eigenaar een bestuurlijke boete op basis van een recente APV van de Gemeente Rotterdam, die voor 6 maanden bepaald wordt en op kan lopen tot 15 .000 euro."

In 2003 heeft het gevreesde team 200 panden bezocht en 101 daarvan bleken illegale pensions. Inmiddels zijn tientallen stalen deuren geplaatst en is op honderd plekken een definitief einde aan de illegale verhuur gemaakt.

Lockhorst zegt over wat er met de bewoners gebeurde: “Dat loste zich vanzelf op. Illegalen willen anoniem blijven, dus die vluchtten weg, soms letterlijk via de dakgoot. Zo ging het in 90 procent van de gevallen. In enkele zeer schrijnende gevallen - bijvoorbeeld complete gezinnen in kleine kamertjes met geldige verblijfspapieren - willen wij bemiddelen. Dan zorgen we er via de woningbouwcorporaties natuurlijk voor dat zij huisvesting krijgen." Naast het terugdringen van de overlast en het herstellen van de veiligheid is er ook een ander bijkomend doel van het opjagen van huisjesmelkers, namelijk het verwerven van panden. Zo kan er meer grip op de huizenmarkt gekregen worden en kunnen er gemakkelijker renovaties uitgevoerd worden. Er waren tot februari 2004 al 128 panden aangekocht door de (deel)gemeente of de Wijkontwikkelingsmaatschappij (WOM) en doorgesluisd naar de deelnemende corporaties voor hun herstructureringsplannen. De intensiteit van de aanpak van het Charloise interventieteam is bijzonder. Hele woonblokken zijn in kaart gebracht die streng in de gaten worden gehouden. Voor de Dordtselaan is een laanmanager aangesteld, die elke dag alles controleert. Hij kijkt al lopend of er panden te koop staan, maar houdt dat ook bij via het kadaster en veilingen. Alle mutaties zijn zo bekend. Bij verkoop heeft de gemeente het voorkeursrecht en zo is zij aan 128 panden gekomen. Inmiddels komen huisjesmelkers hun bezit uit zichzelf aanbieden. Door de stalen deuren en hoge bestuurlijke boetes voelen ze de hete adem in hun nek. Maar niet alleen de huisjesmelkers treffen een harde overheid tegenover zich, ook de huurders kunnen niet meer zo makkelijk tijdelijke bedden beslapen. Lockhorst: "Per 1 februari schrijven wij geen mensen meer in in panden, zonder dat wij ook bij ze thuis zijn gaan kijken. Die panden moeten eerst op orde zijn gebracht. Zolang dat niet het geval is, blijven de huurders uit de bevolkingsadministratie en kunnen zij bijvoorbeeld geen uitkering krijgen."8 
Ten tweede wordt in diverse programma's een 'intrusive' beleid gehanteerd. Een goed voorbeeld daarvan was een werkgelegenheidsproject voor werkloze Antilliaanse jongeren waarbij de projectleider hoogstpersoonlijk de jongens ophaalden als ze niet op kwamen dagen.

"Ik haalde 's morgens die jongens in een oude Mercedes van hun bed af. Nou, er is natuurlijk geen ambtenaar die om half zes die jongens uit hun bed gaat lopen halen. Die gaat om negen uur zitten wachten tot ze op hun opleiding komen. Nou, als ze dan niet komen, dan hebben ze de hele dag een probleem. Maar goed, ik ben natuurlijk ook een zelfstandig ondernemer, dus mijn insteek is ook anders" (Resp. R5).

Voorbeelden van een normerende aanpak vinden we bijvoorbeeld bij de Beatrixschool die 7 basisregels heeft geformuleerd voor ouders en kinderen beginnend bij de eerste schooldag van 4 -jarigen tot de laatste schooldag.

"De kinderen in deze wijk vragen om een heldere structuur, daarna komt pas de rest. Als je het eerste mist, kun je het onderwijs wel op de helling zetten” (Resp. R9)9.

De zeven basisregels van de Beatrixschool

1. Je komt op tijd.

2. Je luistert naar je juf of meester.

3. Je luistert naar elkaar.

4. Je bent rustig.

5. Je helpt elkaar.

6. Je stoort elkaar niet, je pest elkaar niet.

7. Je lost ruzie op door met elkaar te praten.

\subsubsection{VITALE COALITIES EN INTEGRALE SAMENWERKING}

Een derde kenmerk heeft betrekking op het ontstaan van vruchtbare samenwerkingsverbanden die een meer integrale aanpak van problemen en vraagstukken mogelijk maken. In het kader van het grotestedenbeleid is voortdurend benadrukt dat een integrale aanpak van stedelijke problemen en ontwikkelingen noodzakelijk is. Verbetering van de fysieke en economische situatie in de grote steden, bijvoorbeeld door ingrepen in de fysieke leefbaarheid of het stimuleren van de stedelijke werkgelegenheid, kan niet zonder aanvullende sociale interventies. In deelgemeente Charlois en de Tarwewijk zien met name samenwerkingsverbanden waar het gaat om de fysieke pijler (vernieuwing van de woningvoorraad) en de sociale pijler (vergroten van de leefbaarheid en veiligheid). Ook zien we dat er projecten worden ontwikkeld waar publieke en private partijen samenwerken. In het verleden zijn private partijen, met uitzondering van woningcorporaties, amper betrokken bij het oplossen van sociale problemen. Daarin tekent zich een verandering af. Een voorbeeld is de Wijkontwikkelingsmaatschappij 
Tarwewijk (WOM) die recent is opgericht en die bestaat uit projectontwikkelaar Amstelland MDC, het OntwikkelingsBedrijf Rotterdam en woningbouwcorporatie de Nieuwe Unie. In totaal wordt er zo'n 80 miljoen geïnvesteerd in de Tarwewijk. Daarnaast levert ook het ministerie van vROM een bijdrage. Bijzonder is dat projectontwikkelaar Amstelland MDC deelneemt aan dit project waarbij in de komende zeven jaar ruim 1.200 woningen op het programma staan, zowel nieuwbouw als renovatie.

\section{Wijkontwikkelingsmaatschappij Tarwewijk}

Op 29 april 2003 is er een overeenkomst voor de verbetering van de woningvoorraad in de Tarwewijk getekend tussen Projectontwikkelaar AM (Amstelland MDC), de Nieuwe Unie en OntwikkelingsBedrijf Rotterdam (OBR), waarbij de Wijkontwikkelingsmaatschappij (WOM) is opgericht. Het plan is om in de eerste fase tot 2011 circa 1.200 woningen aan te pakken, zowel sloop, nieuwbouw als renovatie. De wом Tarwewijk richt zich in eerste instantie op de aanpak van circa 550 woningen, waarvan de helft nieuwbouwwoningen. De bedoeling is om meer variatie in de woningvoorraad aan te brengen. Door de toevoeging van koopwoningen in de wijk hoopt men de woon- en verblijfskwaliteit te verbeteren. Met nieuwbouwwoningen, maar ook door samenvoeging van bestaande woningen zullen bijvoorbeeld ruimere eengezinswoningen en appartementen beschikbaar komen. Het plan van aanpak tot 2011 betreft 8 verschillende locaties in de wijk. In 2003 is gestart met de aanpak van de Dordtselaan. ${ }^{10}$

Aalbers (2003) heeft recentelijk betoogd dat het buurtverval in de Millinxbuurt en later ook in de aangrenzende Tarwewijk versterkt is door het terugtrekken van de 'bovenwereld' van beleggers en banken en de daaropvolgende overname door de onderwereld in de drugs- en woningmarkt. ${ }^{11}$ Daaraan lijkt nu een einde te komen. Aalbers merkt dan ook op: "De bovenwereld van gemeente, woningbouwcorporaties, banken en projectontwikkelaars probeert de buurt terug te winnen op de onderwereld van huisjesmelkers, druggebruikers, dealers en ongeregistreerde migranten. Woningen worden actief aangekocht van huisjesmelkers. De Rabobank heeft zich opgeworpen als de hypothecaire beschermengel, de vervolging van huisjesmelkers is geïntensiveerd en de grip op drugsdealers die vanuit woningen opereren is toegenomen, dankzij de wet Victoria. ${ }^{12}$ Hiermee verbetert de situatie in de Millinxbuurt aanmerkelijk." (Aalbers 2004: 20)

De ervaringen in de Tarwewijk bevestigen dat in die wijken successen worden geboekt waarin bewoners, corporaties, diensten, ambtenaren en bestuurders erin slagen 'vitale coalities' te sluiten (het begrip is van Pieter Tops, hoogleraar aan de Universiteit Tilburg). Voorbeelden van gesloten coalities in de Tarwewijk zijn de samenwerking tussen Charlois en Feijenoord op het gebied van veiligheid en het TIP, waarin alle partijen die er met jongeren te maken hebben bij elkaar komen. 


\section{Samenwerking deelgemeente Charlois en Feyenoord op het gebied van veiligheid}

De deelgemeenten Feijenoord en Charlois hebben samen met politie en justitie besloten dat ze nog meer gaan samenwerken op de Dordtselaan. De Dordtselaan is in deze aanpak niet meer de scheiding van de deelgemeenten en politiedistricten. De gehele wijk Bloemhof evenals heel Tarwewijk worden bij de aanpak betrokken. Van 2 april tot 15 oktober 2004 zet de politie in het gebied 15 agenten extra in. De volgende zaken zullen aandacht krijgen: de scooteroverlast, preventief fouilleren, overlast gevende plaatsen en panden, de drugsoverlast op straat, de woning- en autocriminaliteit en parkeeroverlast. De deelgemeente zal bekijken hoe de aanpak van illegale bewoning, prostitutie en gokhuizen verbeterd kan worden. Bovendien komen er acties als 'Betere Buurt', waarbij Roteb, Stadstoezicht en Gemeentewerken, de deelgemeente en de politie de wijk extra onder handen nemen om de buurt schoner, heler en veiliger te maken. ${ }^{13}$

TIP

Het Transfer Informatie Punt is gericht op risicojongeren tussen de o en de 24 jaar in de deelgemeente Charlois. Het is een deelgemeentelijke voorziening op het snijvlak van het bestuurlijke, beleidsmatige en uitvoerende domein. Binnen het TIP kan informatie over jongeren overgedragen worden tussen de verschillende partners die op de een of andere manier met die jongeren te maken krijgen. Bovendien is er alle mogelijke informatie voor jongeren en/ of hun ouders beschikbaar met betrekking tot alle mogelijke zorg. ${ }^{14}$

"Wat we dus doen: we trekken hier als het ware letterlijk en figuurlijk partijen naar binnen in de zin van jeugdhulpverlening, strafrechtketen, onderwijs, werk en inkomen. Wij zijn ervoor op het moment dat die organisaties die gewoon aan het werk zijn met jongeren tot de conclusie komen: 'We hebben hier een jongere en daar is meer mee aan de hand dan standaard. Wij komen er niet uit, want daar zit een frustratie en daar loopt het niet.' Dan zijn ze pas voor hier en niet eerder." Er wordt naar gestreefd om tot een samenhangende aanpak te komen, waarbij getracht wordt te voorkomen dat er zich te veel instanties tegelijk met de situatie bemoeien. Per geval wordt er daarom één instantie als hoofdverantwoordelijke aangesteld.

Voorbeelden van problemen die bij overleggen tussen de partijen besproken worden "variëren van een klein kind dat's nachts alleen thuis aangetroffen wordt door de buurtagent, naar aanleiding van een melding van de brandweer die lekkage ziet, tot een pleeggezin dat het huis uitgezet is en nu ergens in een tuinhuisje zit en vandaar uit irreguliere dingen doet, en waarvan de helft van het gezin weer is vastgezet door de politie. (...) Maar ook meisjes die vermoedelijk in het loverboy-circuit zitten, ja of nee, een jongen die naar een drugsafkickcentrum moet. Kortom, het is heel gevarieerd. Het gaat niet alleen over een leerplichtige die niet naar school gaat, of potentiële criminelen die onderweg zijn of weer terug, maar het hele scala komt aan bod. En ja, iedere keer zitten er weer verrassende elementen in. Een keer in de twee weken komt er wel een situatie naar voren waarvan je het bestaan nog niet af weet. En dat zijn hele aparte situaties” (Resp. R3).

\subsubsection{VOORBIJ HET WIJKNIVEAU}

Naast activiteiten en projecten die gericht zijn op het bestrijden van problemen in de wijk wordt door bestuurders in de deelgemeente Charlois, net als door bestuurders op het gemeentelijke stadhuis, een toenemend beroep gedaan op bovenstedelijke partijen om bij te dragen aan de verlichting van problemen in Charlois. 
$\mathrm{Al}$ eerder is melding gemaakt van het pleidooi dat Dominic Schrijer heeft gehouden voor een meer evenwichtige spreiding van kansarmen over stad en regio. Hij hanteerde daarbij overigens wel een specifieke definitie van kansarmen, namelijk degenen die aantoonbaar niet in staat zijn om voor zichzelf en eventuele gezinsleden te zorgen (bijvoorbeeld illegale vreemdelingen en dak- en thuislozen). Essentiële voorwaarden voor het zichzelf kunnen handhaven zijn: het op legale manier kunnen voorzien in eigen levensonderhoud (inkomen) en het hebben van rechtmatige huisvesting. Het stadsbestuur zou later verdergaande criteria ontwikkelen, in het bijzonder het stellen van inkomenseisen en integratie-eisen aan woningzoekenden van buiten de regio. Ook dringt het stadsbestuur er sterk op aan dat er in de stadsregio Rotterdam meer woningen beschikbaar komen voor huishoudens met een laag inkomen en dat er een regionaal aanbod komt voor bijzondere doelgroepen (drugsverslaafden, dak- en thuislozen). De boodschap over sociale grenzen aan het absorptievermogen van bepaalde wijken heeft inmiddels brede erkenning gevonden. De Rotterdamse maatregelen om tot een selectief vestigingsbeleid over te gaan worden door het kabinet ondersteund. ${ }^{15}$

In de actuele discussie over de positie van Antillianen in Nederland is het vraagstuk van de begrensde absorptiecapaciteit van wijken opnieuw aan de orde gekomen. Er is sprake van een forse toename van het aantal Antillianen dat naar Nederland vertrekt. Een deelgemeente als Charlois heeft daar nadrukkelijk mee te maken. Inmiddels wonen er bijna 4700 Antillianen in de deelgemeente Charlois (een stijging van ruim 50 procent in vergelijking met het jaar 1998). Hun aanwezigheid draagt bij aan problemen rond uitkeringsafhankelijkheid, overlast, overbewoning en criminaliteit. Om die reden heeft wethouder Schrijer erop aangedrongen om de toestroom van (kansarme) Antillianen naar Nederland te stoppen door middel van een herziening van de bestuurlijke relatie van Nederland met de Nederlandse Antillen. ${ }^{16}$ Ook dit voorbeeld geeft aan dat er een groeiend besef is dat voor het oplossen van wijkproblemen niet alleen lokale en regionale maatregelen nodig zijn, maar ook nationale en internationale maatregelen.

\section{$5 \cdot 4$ DISCUSSIE}

De nieuwe aanpak zoals die zichtbaar wordt in de deelgemeente Charlois is een reactie op een aantal structurele problemen zoals die de afgelopen decennia zijn ontstaan in de wijken in de grote steden. Daarbij wordt een zwaar accent gelegd op verbetering van de leefbaarheid en veiligheid en op het voeren van een selectief vestigingsbeleid door middel van het stellen van eisen aan nieuwkomers en het veranderen van de bestaande woningvoorraad waardoor op termijn meer hogere inkomensgroepen in de wijk wonen. Bij deze aanpak, die door ons gekarakteriseerd is als 'sociale herovering' kunnen de volgende vier kanttekeningen worden geplaatst.

Ten eerste blijft de werkgelegenheidsituatie in Rotterdam een problematisch punt. Op deelgemeenteniveau of wijkniveau is daar heel weinig aan te doen. Een verbetering van de stedelijke arbeidsmarkt is echter een belangrijke voorwaarde 
voor een verbetering van de maatschappelijke positie van de wijk en haar bewoners.

Een tweede kanttekening betreft de waarneming dat de nieuwe beroepsgroepen (buurtconciërges, laanmanagers) al wijzen op nieuwe vormen van afhankelijkheid: zij knappen het wel op voor de bewoners. Daarom is het essentieel dat naast het verbeteren van de kwaliteit van de wijk, ook de maatschappelijk positie van de bewoners verbetert opdat zij zelfstandiger kunnen functioneren.

Een derde kanttekening betreft de implementatie van het selectieve vestigingsbeleid en het regionale huisvestingsbeleid ten behoeve van kansarme groepen. De vraag is in hoeverre een dergelijk vestigings- en spreidingsbeleid daadwerkelijk gerealiseerd zal worden. Men zal bedacht moeten zijn op ongewenste effecten (mogelijk toename van illegale vestiging) en op de begrensde medewerking van randgemeenten en woningbouwcorporaties om kansarme groepen te bedienen. Veldboer en Duyvendak (2004: 49) merken in dit verband terecht op dat de mogelijkheden voor sturing van de lokale overheid gering zijn. De overheid is vooral aanjager geworden, waardoor het maar de vraag is of hoe haar hoge aspiraties worden gerealiseerd.

Een vierde kanttekening betreft de stigmatiserende werking van Rotterdamse voorstellen. Het selectieve vestigingsbeleid wordt ook wel beschouwd als een 'allochtonenstop' en kan relaties tussen autochtone en allochtone bewoners en tussen Rotterdamse bestuurders en migrantengroepen doen verslechteren. 


\section{NOTEN}

I In Rotterdam worden ook de eerste serieuze voorstellen ontwikkeld voor additionele werkgelegenheids- en armoedebestrijdingsprogramma's die later onder invloed van minister Melkert van Sociale Zaken en Werkgelegenheid in het eerste paarse kabinet een forse impuls krijgen. Wijken die op de Veiligheidsindex gelabeld zijn met 'onveilig'.

3 Gebieden in de onveilige wijken, waar criminaliteit, vervuiling en verloedering het beeld bepalen. Gemeente Rotterdam (2002) 'Stadsmariniers stuwende kracht voor veiliger Rotterdam'. In: Nieuw Rotterdams Tij, editie 11, jaargang 2002. Gemeente Rotterdam (2003), 'Vertrouwen vertrekt te paard en komt te voet'. In: Nieuw Rotterdams Tij, editie 2, jaargang 2003.

6 Bron: Gemeente Rotterdam, dS+V.

7 Gebaseerd op G. Engelen (2004), 'Stalen deuren in Charlois'. In: Lokaal Bestuur, 1 maart 2004. De cijfers die hierin genoemd worden, zijn afkomstig van de heer Lockhorst (voorzitter deelgemeente Charlois) die op een bijeenkomst in februari 2004 in de Millinxbuurt over de twee voorgaande jaren sprak.

8 Het project interventieteams is winnaar geworden van de eerste Rotterdamse Aanpak Prijs. De prijs, een stoere gereedschapskist, symbool voor aanpakkers, werd medio juni uitgereikt door wethouder Marco Pastors. Gemeente Rotterdam (2004), 'Project Interventieteams wint Rotterdamse Aanpak Prijs'. In: Nieuwe Rotterdams Tij, editie 6, jaargang 2004.

9 Resp. R9: Directeur basisschool 'De Beatrixschool'.

10 De Nieuwe Unie, 'Start aanpak Tarwewijk. Gemeente, AM en de Nieuwe Unie starten met aanpak Tarwewijk'. Uit: http://www.denieuweunie.nl/. Aalbers publiceerde in 2003 de studie Redlining in Nederland: Oorzaken en gevolgen van uitsluiting op de hypotheekmarkt. Amsterdam: Aksant. Daarin toonde hij aan dat eind jaren negentig banken niet of nauwelijks hypotheken verstrekten in de Millinxbuurt. De Rabobank gebruikte een postcodelijst waar achter postcode 3081 (Millinxbuurt en Tarwewijk) code III stond, dat 'niet financieren' betekende. Alle grote banken maakten gebruik van een dergelijke methode, die ook wel redlining wordt genoemd. De Wet Victoria houdt in dat op grond van artikel 174a Gemeentewet een burgemeester een bezoekersverbod op kan leggen, dan wel een woning sluiten, indien er sprake is van een (ernstige) verstoring van de openbare orde, welke een voortdurende aantasting van de veiligheid en gezondheid van de omwonenden met zich brengt.

Deelgemeente Charlois (2004), Folder 'Extra inzet in de Tarwewijk en Bloemhof', 30 maart 2004.

14 TIP (2004), Informatieflyer Transfer Informatie Punt.

15 Het kabinet heeft inmiddels positief gereageerd op de Rotterdamse plannen. Grote steden mogen in de toekomst in een beperkt aantal, door henzelf aan te wijzen achterstandswijken een inkomenseis stellen aan mensen die zich daar willen vestigen. Het kabinet zal dit mogelijk maken in een speciale wet. Maar dit 
mag pas als de stad zelf eerst de eigen huisvestingsverordening beter benut. Zie Brief aan de Tweede Kamer over de kabinetsreactie op het Actieprogramma 'Rotterdam zet door' 2004, Kamerstukken I, 2003/04, 21062, nr. 111.

16 Zie: Dominic Schrijer en Jeroen Dijsselbloem, 'Stop toestroom Antillianen', in: de Volkskrant, 6 juli 2004. Daarin schetsen zij twee opties voor het herzien van het Koninkrijksstatuut: volledige onafhankelijkheid of volledig onderdeel worden van Nederland. 


\section{BUURTREGIE IN OVERTOOMSE VELD}

\subsection{INLEIDING}

In het vorige hoofdstuk over de 'Rotterdamse aanpak' is melding gemaakt van een soort paradigmawisseling in het stedelijk sociaal beleid. Die wisseling van beleid is nadrukkelijk totstandgekomen na de opkomst van Fortuyn en de entree van Leefbaar Rotterdam in de gemeenteraad. Al moet hieraan worden toegevoegd dat sommige beleidsinitiatieven als de oprichting van interventieteams, Opzoomeren en stadsetiquette al eerder waren ontwikkeld.

In Amsterdam is veel minder sprake geweest van zo'n geprofileerde verandering in de lokale politiek. Dat komt mooi tot uiting in het Sociaal Structuurplan Amsterdam 2004-2015 Wat Amsterdam beweegt (2004). Daarin wordt de dynamiek van de stad als uitgangspunt genomen en worden drie doelstellingen geformuleerd: investeren in grootstedelijke dynamiek, investeren in menselijk kapitaal en investeren in een leefbare omgeving. Men poogt bestaande programma's beter uit te voeren en tot betere samenwerking te komen. Maar er wordt geen nieuwe ideologische koers ingeslagen. We zien echter wel dat er in het collegeakkoord Alleen het resultaat telt (2002) net als in het collegeprogramma van Rotterdam een sterker accent komt te liggen op het realiseren van concrete resultaten waarop men afgerekend kan worden. Bovendien was er in Amsterdam-West een gebeurtenis die grote invloed had op de wijze waarop men sociale problemen in de wijk aanpakte. Na de al gememoreerde rellen van 1998 ziet men - na een periode van bezinning - op diverse beleidsterreinen nieuwe aanpakken en beleidsinitiatieven opkomen, die vergelijkbaar zijn met de Rotterdamse aanpak.

Contact met burgers, aandacht voor alledaagse problemen in de buurt, een hardere aanpak van jongeren die de regels overschrijden en het streven naar een meer gemengde woningvoorraad om de middengroepen voor de buurt te behouden, zijn trefwoorden in de nieuwe aanpak van stedelijke problemen in Amsterdam-West. Aangezien de meeste van deze nieuwe aanpakken en initiatieven in de jaren 2000-2002 in gang werden gezet, is het nog te vroeg om te kunnen zeggen of ze echt resultaat opleveren.

Wie de aanpakken in Amsterdam en Rotterdam beschouwt, kan niet anders constateren dan dat ze op centrale punten sterk op elkaar lijken. We zullen derhalve de Amsterdamse aanpak in Overtoomse Veld in dezelfde termen duiden als die we gebruikt hebben voor de aanpak in de Rotterdamse Tarwewijk.

Ook in Amsterdam gaat het in essentie om vier dingen. In de eerste plaats moeten beleidsvoerders om effectief in buurtproblemen te kunnen ingrijpen veel beter kennis hebben van de lokale situatie en de problemen die daarin 
spelen. Het transparant maken van de buurt is een eerste voorwaarde voor een effectief stedelijk sociaal beleid.

In de tweede plaats moeten problemen ook echt worden aangepakt. Trefwoorden in de nieuwe aanpak van stedelijke problemen zijn: (1) een repressieve aanpak, (2) het stellen én handhaven van normen, en (3) indien nodig interveniëren in het dagelijkse leven van mensen. Met deze aanpak wordt er afscheid genomen van het vroegere, relatief vrijblijvende beleid. Veel bewonersproblemen werden niet opgelost en vaak niet eens waargenomen. $\mathrm{Nu}$ is het motto dat sociale problemen in de stad moeten worden benoemd en indien mogelijk worden opgelost. Een exemplarisch Amsterdams voorbeeld van deze nieuwe, meer doortastende aanpak van grotestadsproblemen is de zogenaamde 'harde kernaanpak' om jeugdcriminaliteit te bestrijden. De gemeente schrikt er daarbij niet voor terug om problematische jongeren voor een jaar naar een 'heropvoedingsinstelling' te sturen. Maar ook op andere beleidsterreinen zien we de opkomst van meer gerichte aanpakken, waarbij interventies in het dagelijks leven van mensen niet worden geschuwd.

Een derde element is dat al deze nieuwe aanpakken en initiatieven vaak een vergaande samenwerking vergen tussen diverse betrokken partijen. Het aangaan van vitale coalities, integraal werken en ketenaanpak zijn ook in Amsterdam de nieuwe sleutelwoorden van het stedelijk sociaal beleid. De gedachte hierachter is overigens geenszins nieuw. Al in de jaren negentig werden er in het welzijnswerk al zogenaamde 'buurtnetwerken' gevormd waarin professionals van allerlei instanties met enige regelmaat samenkomen om concrete cases (bijv. problematische jongeren) te bespreken en een gezamenlijk aanpak af te spreken. Het doel van deze buurtnetwerken was tweeledig; enerzijds onderlinge informatieuitwisseling tussen alle betrokken partijen en anderzijds het afspreken van een samenhangende aanpak van een probleem, zonder dat betrokken instanties langs elkaar heen werken of elkaar zelfs in de wielen rijden. Wie de praktijk van sociaal beleid in het stadsdeel Slotervaart overziet, ziet tal van zulke netwerkachtige samenwerkingsverbanden tussen professionals en instellingen van zeer diverse pluimage. Er moeten echter twee kanttekeningen gemaakt worden bij deze integrale aanpak van problemen. In de eerste plaats kunnen we constateren dat deze samenwerkingsverbanden vooral bevolkt worden door personen die we als 'publieke professionals' kunnen betitelen. Betrokkenheid van particuliere partijen (bijv. bedrijven) en spontane initiatieven van burgers zijn er wel, maar komen slechts sporadisch voor. In de tweede plaats blijkt het welzijnswerk zijn vooraanstaande positie bij de aanpak van stedelijke sociale problemen te zijn kwijtgeraakt. Het professionele welzijnswerk speelt nog slechts een bescheiden rol in het stedelijk sociaal beleid in Amsterdam-West.

Een vierde en laatste trefwoord bij de nieuwe aanpak van stedelijke bewustzijn is het bewustzijn dat niet alle problemen op lokaal niveau kunnen worden aangepakt, maar soms de betrokkenheid van bovenlokale partijen (regiogemeenten, landelijke overheid) vergen. Vergeleken met Rotterdam hoort men dit geluid in 
Amsterdam echter betrekkelijk weinig. Integendeel, lokale autoriteiten huldigen veelal de opvatting dat het nieuwe lokale beleid op de goede weg is om de problemen in de stad aan te pakken. Wel zien we in Amsterdam een vrij creatieve en pragmatische manier van omgaan met de binnenstedelijke decentralisatie. Waar enerzijds de centrale stad en de stedelijke diensten soms te ver afstaan van de praktijk van sociaal beleid, maar anderzijds de afzonderlijke stadsdelen soms te weinig draagvlak hebben om problemen echt te kunnen oplossen, zien we in Amsterdam-Nieuwwest een nieuwe bestuurslaag tussen het stedelijke en het stadsdeelniveau ontstaan. Zo wordt de stedelijke vernieuwing aangepakt door het reeds genoemde Bureau Parkstad, dat vier stadsdelen omvat. Opmerkelijk is ook dat de politie en justitie in Amsterdam-Nieuwwest op dit tussenniveau zijn georganiseerd (resp. District 6 van de Amsterdamse politie en Justitie in de Buurt in Amsterdam-Nieuwwest).

Om hardnekkige problemen in buurten aan te kunnen pakken moeten er hoge eisen gesteld worden aan de sociale herovering. Dit is maar weer al te duidelijk geworden bij de recente gebeurtenis in de Amsterdamse Diamantbuurt, waarbij Marokkaanse jongeren een echtpaar dermate intimideerden dat dit de buurt heeft verlaten. Deze gebeurtenis liet zien hoe belangrijk het is om een dergelijke buurt te 'heroveren' en hoe hard een indringende aanpak nodig is, er door verschillende partijen goed samengewerkt dient te worden en de aanpak toegesneden moet zijn op het betreffende probleem.

\subsection{HET TRANSPARANT MAKEN VAN DE WIJK}

Een eerste voorwaarde voor effectief ingrijpen in de vaak zeer complexe problematiek in een multiculturele achterstandswijk als Overtoomse Veld is dat de betrokken instanties (gemeentebestuur en allerlei ambtelijke diensten, maar ook de politie, sociale dienst, scholen, enz.) kennis hebben van wat er in de wijk gebeurt. Dit bleek lang niet altijd het geval. Op allerlei beleidsterreinen zien we daarom nieuwe initiatieven van diverse instanties om beter zicht te krijgen op de situatie in de wijk. Een typerend voorbeeld is de 'operatie zoeklicht', waarbij middels een integrale aanpak van corporaties, gemeente, sociale dienst, belasting en socialezekerheidsinstellingen, is opgetreden tegen illegale bewoning en onderhuur. Een grappig detail is dat buurtconciërges in opdracht van de corporaties de taak hebben het afwezig zijn van naambordjes te bestrijden. Andere voorbeelden daarvan zijn:

- het in kaart brengen problematische jeugdgroepen;

- recherchematig werken door politie en casuïstiek overleg;

- centrale informatievoorzieningen 'first offenders' (јот);

- het aanstellen van buurtregisseurs;

- het in kaart brengen voortijdige schoolverlaters;

- huisbezoeken in het kader van het Sociaal Investeringsplan (SIP) in Overtoomse Veld.

We zullen deze zes voorbeelden kort toelichten. 


\section{In kaart brengen problematische jeugdgroepen}

Bij de vaststelling van het Plan Jeugd en Veiligheid 2003 door de politie in Amsterdam-Nieuwwest (District 6) werd gekozen voor een groepsbenadering van jeugdcriminaliteit en overlast door jongeren. De reden was dat veel criminaliteit en overlast door jongeren in groepsverband gebeurt. Individueel zouden veel jongeren bepaalde delicten misschien niet plegen, maar gezamenlijk doen ze dat wel. Deze beleidskeuze betekende een ommezwaai in de traditionele aanpak, niet alleen van de politie, maar ook van andere instanties. De coördinator jeugdproblematiek van de Amsterdamse politie in District 6:

"Het grote probleem met jeugd in Amsterdam-West is gedrag van jongeren in groepen en de gezinsproblematiek. Alle betrokken instanties, niet alleen politie maar ook welzijn, werken vanouds met een individuele aanpak van personen. Een gezins- of groepsaanpak is iets nieuws, wat nog ontwikkeld moet worden" (Resp. A5)․

Een eerste voorwaarde voor een groepsgerichte aanpak van jeugdgroepen is dat men precies weet om welke jongeren het gaat en wat ze hebben gedaan. Hiertoe is afgesproken om alle problematische jeugdgroepen in Nieuwwest te inventariseren volgens een methode ontwikkeld door de criminologen Beke et al. (200o). Van iedere jeugdgroep wordt nagegaan wie er precies deel uitmaken van de groep. Vervolgens wordt met hulp van politiegegevens nagegaan welke delicten deze jongeren hebben gepleegd. Op deze wijze krijgt men inzicht in het totale aantal delicten gepleegd door alle jongeren in een groep. Omdat niet alle delicten even ernstig zijn, wordt aan verschillende soorten delicten een verschillende score toegekend. Uiteindelijk krijgt men zo per jeugdgroep een beeld van de ernst van de delicten die de leden plegen. Op basis van dit totaalbeeld wordt vervolgens een onderscheid gemaakt tussen drie soorten jeugdgroepen: hinderlijke, overlast gevende en criminele groepen. Als sprake is van zeer veel én ernstige delicten wordt van een 'jeugdbende' gesproken, maar dit komt in de praktijk weinig voor.

Hinderlijke jeugdgroepen zijn jongeren die op straat rondhangen, soms luidruchtig zijn of zich schuldig maken aan kleine vernielingen, maar verder niet erg problematisch zijn. Overlast gevende jeugdgroepen zijn nadrukkelijker aanwezig in de buurt. Zij vallen soms voorbijgangers lastig, vernielen regelmatig dingen en zijn moeilijker te corrigeren. Ook plegen zij lichte vormen van criminaliteit. Criminele jeugdgroepen bestaan (in ieder geval gedeeltelijk) uit jongeren die veel verder op het criminele pad zijn terechtgekomen. Zij plegen meer en vaak ook zwaardere delicten en doen dat voor financieel gewin (Beke et al. 2000: 25).

Inmiddels heeft de politie van District 6 op deze wijze in totaal 26 jeugdgroepen in kaart gebracht, waaronder zeven groepen in het stadsdeel Slotervaart. Van de 26 jeugdgroepen in heel Amsterdam-Nieuwwest werden er zeven als 'crimineel' gekenschetst, vier als 'overlast gevend' en veertien als 'hinderlijk'. Eén groep (in Osdorp) was dermate crimineel dat sprake is van een jeugdbende. In het stads- 
deel Slotervaart zijn zeven jeugdgroepen in kaart gebracht; het betrof twee criminele, twee overlast gevende en drie hinderlijke groepen.

De ratio achter de exercitie is dat het bij de aanpak van jeugdgroepen cruciaal is om een onderscheid te maken tussen enerzijds criminele groepen en jongeren en anderzijds groepen en jongeren die (nog) niet crimineel zijn. Criminele groepen en jongeren vergen volgens de huidige Amsterdamse beleidsvisie een 'harde aanpak'. Een recente studie pleit in geval van criminele groepen voor een combinatie van repressie en individuele trajectbegeleiding, gericht op 'het breken van de groep' en op het leiden van jongeren naar onderwijs en arbeid. Bij niet-criminele groepen en jongeren is een meer welzijnsachtige aanpak op zijn plaats: enerzijds repressief om te voorkomen dat de groep echt crimineel wordt, anderzijds activiteiten als begeleiding door een mentor of professionele begeleider en georganiseerde vrijetijdsactiviteiten.

"Omdat vandalisme vaak ontstaat door een gebrek aan een positief alternatief is er met het inzetten van (...) vrijetijdsactiviteiten bij een dergelijke groep veel te bereiken.” Voor alleen hinderlijke straatgroepen is tenslotte geen speciale aanpak vereist, al kan men buurtavonden of feesten voor deze jongeren (helpen) organiseren of hen in gesprek brengen met oudere buurtbewoners. ${ }^{2}$

\section{Recherchematig werken door politie en casuïstiek overleg}

Per 1 januari 2003 is in Amsterdam de 'Aanpak harde kern jeugd' formeel van start gegaan. Deze aanpak richt zich op circa 1500 jeugdcriminelen in Amsterdam (waaronder 300 tot 400 jongeren in Amsterdam-West ${ }^{3}$ ), die zich stelselmatig aan delicten schuldig maken. Het doel is dat dit aantal harde kernjongeren in 2006 met 20 tot 30 procent is verminderd. Tevens beoogt de harde kernaanpak te voorkomen dat jongeren die nu (nog) niet of alleen licht crimineel zijn steeds zwaarder in criminaliteit verwikkeld raken en tot de harde kern zullen gaan behoren. De harde kernaanpak bestaat uit een groot aantal maatregelen van diverse partijen. Twee van deze maatregelen hebben betrekking op informatieverwerving en het transparant maken van de stad, het recherchematig werken door de politie en het casuïstiek overleg over jongeren in de buurt.

Recherchematig werken betekent dat de politie ook voor lichte delicten uitzoekt wat een verdachte allemaal op zijn of haar kerfstok heeft. Tot voor kort werden (jeugdige) verdachten meestal voor afzonderlijke delicten voor de rechter gezet. $\mathrm{Nu}$ wordt eerst volledig uitgezocht wat zo'n jongere allemaal heeft misdaan (dossier opbouwen), zodat bij een rechtszaak het hele dossier op tafel ligt. Volgens zegslieden is dit een ingrijpende verandering in de werkwijze van de politie. 
“De stad heeft alle gegevens van veelplegers, waaronder veel allochtone jongeren, op een rij gezet. Die gaan we in deze volgorde 'achterover drukken', zoals dat heet. De politie maakt dossiers klaar van alles wat die jongeren misdaan hebben, dan wachten ze tot meneer een autokraak of iets anders pleegt en dan wordt hij met dat hele dossier voor de rechter gezet. Alleen de gerechtelijke uitspraak is nog niet voorbereid, maar verder ligt alles klaar. Met dit instrument zijn in deze wijk zeker 25 veelplegers opgepakt en voor minimaal een jaar 'weggezet' in centra als Den Engh” (Resp. A4).

"We zijn ons meer gaan richten op de hardere criminelen onder jongeren, de harde kernaanpak. We richten onze aandacht op bepaalde jongeren, verzamelen en bundelen alle informatie over deze jongeren, bedenken allerlei volgsystemen en ontwikkelen een beleid voor die jongere: zoveel mogelijk informatie stapelen zodat die jongere een tijdje van de straat is en naar een heropvoedingsinstelling gaat. Dit begon allemaal een jaar of twee geleden. We zijn ons bewust geworden van de veelplegers. Voor die tijd waren we ons hiervan niet bewust, we vervolgden jongeren voor afzonderlijke incidenten. $\mathrm{Nu}$ we ons daarvan bewust zijn, gaan we bepaalde jongeren volgen en informatie over hen verzamelen. Bij de nieuwe aanpak is goede informatie heel belangrijk. Je moet precies weten welke jongeren je moet hebben en wat hij op zijn kerfstok heeft. Je probeert zo'n probleemjongere een tijdje uit de groep te halen” (Resp. A5).

“De opzet is dat je met verschillende partners om tafel gaat zitten en per gebied nagaat welke personen verantwoordelijk zijn voor een groot deel van de delicten in dat gebied. We brengen dus de harde kern van veelplegers in kaart en vervolgens wordt er per individu een plan van aanpak afgesproken. We brengen dus het verleden en heden van de betrokkene in beeld, maar zeggen ook iets over de toekomst. Als zo'n jongere weer een strafbaar feit pleegt, dan weten we al wat het plan van aanpak zal zijn. Op dit moment staan er in Amsterdam-West 160 jongeren (tot 25 jaar) op de harde kernlijst. De bedoeling hiervan is vooral om richting te geven aan strafzaken, dat je niet meer op zichzelf staande strafzaken afhandelt, maar persoonsgericht waarbij het hele verleden van iemand meeweegt in de strafoplegging” (Resp. A7).

Een belangrijk onderdeel van de harde kernaanpak is het zogenaamde casü̈stiek overleg, waarin vertegenwoordigers van allerlei betrokken instanties (politie, justitie, Bureau Jeugdzorg, Raad voor de Kinderbescherming, jongerenwerkers, enz.) individuele jongeren bespreken. Het doel van dit overleg is enerzijds om een beter beeld van problematische jongeren te krijgen en anderzijds om tot een betere coördinatie van de jeugdhulpverlening te komen. Dit overleg wordt in de diverse stadsdelen verschillend ingevuld.

In het stadsdeel Osdorp is het echt gericht op problematische en criminele jongeren. Het kortgeleden opgerichte Netwerk 12+ in het stadsdeel Slotervaart houdt zich niet alleen met criminele jongeren bezig, maar met allerlei jongeren met problemen (bijv. ook schoolverlaters).

De 'buurtregisseur' in Overtoomse Veld (zie hierna) schetst de werkwijze van het 'Netwerk 12+' als volgt. 
"Iemand brengt een bepaalde jongere in en dan zeggen alle partijen of ze die betreffende jongere kennen of onder behandeling hebben. Dan spreken we gezamenlijk af wat er met die jongere moet gebeuren. Bijvoorbeeld dat de reclassering of hulpverlening nu moet ingrijpen. Dan wil ik over twee weken horen wat er precies voor die jongere is georganiseerd. In de praktijk wacht ik dan niet twee weken, vaak bel ik al na een paar dagen op om te kijken of men al iets voor de jongere heeft gedaan. Je moet het vuurtje steeds opstoken" (Resp. A8).

\section{Informatievoorziening Jongeren Opvang Team (Јот)}

Ook het Jongeren Opvang Tеam (ЈОт) is een samenwerkingsverband tussen diverse partijen. Naast politie en justitie zijn dat Bureau Jeugdzorg Amsterdam, de Raad voor de Kinderbescherming, Halt en de gemeente (stadsdelen). Het JOT heeft een eigen ruimte in het politiebureau Meervaart (Osdorp), waar alle medewerkers van de genoemde organisaties ook een eigen werkplek hebben. Het JOT richt zich op zogenaamde 'first offenders', die woonachtig zijn en een delict hebben gepleegd in Amsterdam-West. In principe komen alle zaken tegen jeugdige verdachten in het district eerst bij het јот terecht. Неt јот bekijkt dan of men de zaak zelf - zonder tussenkomst van de rechter - kan afhandelen. Het JOT heeft de bevoegdheid om zelfstandig taakstraffen op te leggen en kan daarnaast jongeren doorsturen naar hulpverlening.

Cruciaal voor de werkwijze van het јОт is dat de medewerkers van alle genoemde partijen op het politiebureau toegang hebben tot de gegevensbestanden van de eigen organisatie. Wanneer een jongere bij het JOT wordt aangemeld, dan kijken de medewerkers van alle betrokken instanties eerst in de eigen gegevensbestanden of er bij hen iets over de betreffende jongere of diens gezin bekend is. Door deze werkwijze heeft men het mogelijk gemaakt om informatie van allerlei instanties op zeer snelle wijze met elkaar te kunnen combineren, zonder de privacyregels te overschrijden. De gegevensbestanden worden immers niet gekoppeld en blijven alleen toegankelijk voor medewerkers van de eigen dienst (zij het dat die werkzaam zijn op het politiebureau).

Een tweede belangrijk aspect van de werkwijze van het JOT is de 'screening'. Wordt een jongere door het јОт in behandeling genomen, dat begint de interventie met een uitvoerig gesprek ('screening'). In dit gesprek wordt niet alleen over het gepleegde delict gesproken, maar probeert men een beeld te krijgen van de hele leefsituatie van de jongere (thuis, school, werk, vriendenkring, vrijetijdsbesteding, enz.). Bij dit gesprek zijn ook de ouders van de jonge verdachte aanwezig. Deze screening is volgens medewerkers van het JОт het belangrijkste verschil tussen de werkwijze van het јОт en soortgelijke initiatieven elders. Vervolgens wordt de vergaarde informatie (net als bij het casuïstiek overleg) binnen het multidisciplinaire team van јот besproken, hetgeen uitmondt in een gezamenlijke aanpak (bijv. hulpverlening, georganiseerde vrijetijdsbesteding, sociale vaardighedentraining, een leer- of taakstraf dan wel een combinatie). 


\section{De buurtregisseur}

De Amsterdamse politie heeft behoorlijk geïnvesteerd in het aanstellen van buurtregisseurs. Alleen al in het stadsdeel Slotervaart werken acht buurtregisseurs, waarvan twee in de buurt Overtoomse Veld. Binnen de politie bestaan overigens verschillende opvattingen over de rol van de buurtregisseur (voorheen wijkagent). In sommige korpsen handelt de buurtregisseur de kleine criminaliteit in de buurt af, terwijl grotere zaken worden overgelaten aan de recherche. In andere korpsen fungeert de buurtregisseur als een tussenschakel tussen de buurt en de politie en voelt de buurtregisseur zich verantwoordelijk voor het hele politieoptreden in de buurt. In Amsterdam is men deze laatste mening toegedaan.

“Je houdt je met een bepaalde buurt bezig en voelt je verantwoordelijk voor alles wat er daar op het gebied van leefbaarheid en veiligheid gebeurt. Ook al kan ik het niet altijd veranderen, ik voel me wel verantwoordelijk voor wat er gebeurt. Als er veel diefstallen uit auto's zijn, dan heb ik daar buikpijn van. Dat heb ik ook als buren ruzie met elkaar hebben of elkaar naar het leven staan. Je kunt zowel bij kleine als bij grote zaken een rol spelen. Zo voed ik de recherche met informatie over wat er gebeurt in de buurt, zij gebruiken die informatie weer in rechercheonderzoeken. Tegelijkertijd ben ik betrokken bij allerlei preventieve activiteiten. Er is geen tegenstelling tussen repressie en preventie" (Resp. A8).

Cruciaal in de taak van buurtregisseur is mensen c.q. jongeren in de buurt te kennen en individueel aan te spreken. Juist bij jongeren is het belangrijk om hen uit de anonimiteit te halen en individueel op hun gedrag aan te spreken.

“Onze prioriteit zijn de probleemjongeren. Het contact met hen is van levensbelang. Ik kan niet zomaar anoniem langslopen. Ik geef iedereen een hand, maak altijd een praatje. Ik moet telkens de balans behouden tussen gezag en sociaal contact."

En:

"Wij zijn de huisartsen van de politie."4

De buurtregisseur heeft niet alleen met jongeren te maken, maar met allerlei personen en organisaties in de buurt.

"Het is hier net een dorp, in het midden staat de moskee waar iedereen elkaar ontmoet. Het is een gesloten gemeenschap, maar via de juiste ingangen kun je die toch bereiken. Zo zijn de Marokkaanse buurtvaders een belangrijke ingang. De jongerenvereniging Oportuna, waar alle jongeren uit de buurt komen, is een andere ingang. Ook het bestuur zijn allemaal jongens uit de buurt, die weten wat er aan de hand is. Als buurtregisseur probeer ik mensen en organisaties met elkaar in contact te brengen" (Resp. A8). 


\section{In kaart brengen voortijdige schooluitval}

Ook op andere gebieden dan politie en veiligheid wordt naar meer transparantie gestreefd. Zo is men zich de laatste jaren steeds meer bewust geworden dat voortijdige schooluitval van allochtone jongeren een enorme belemmering is voor hun latere arbeidsmarktkansen. Om hieraan iets te kunnen doen, moet men echter eerst weten hoeveel en welke jongeren voortijdig van school zijn gegaan. Dit is vaak niet bekend. Scholen zijn wel verplicht om schoolverlaters te melden, maar dit gebeurt niet altijd. Daarbij weet men dan niet of jongeren inmiddels weer op een andere school zitten. Vaak merkt men pas dat een jongere voortijdig van school is gegaan wanneer hij of zij met 18 jaar een bijstandsuitkering aanvraagt, maar soms zit de jongere dan al een jaar lang thuis. Om meer zicht op deze problematiek te krijgen, heeft de gemeente Amsterdam opdracht gegeven om na te gaan welke jongeren (vooralsnog alleen 17-jarigen) zonder minimale startkwalificatie van school zijn gegaan. Een betrokkene vertelt hierover.

"Nu gaan casemanagers van het stadsdeel kijken wat er met deze jongeren aan de hand is. Jongeren worden voor een gesprek opgeroepen. Door deze gesprekken blijkt het systeem niet helemaal betrouwbaar. Sommige jongeren zitten toch op school, anderen zitten in detentie, sommigen blijken te werken (maar zonder startkwalificatie). Tenslotte zijn er jongeren waarvan men niet kan achterhalen wat ze doen en waar ze wonen. Deze laatste jongeren worden besproken in het netwerk 12+ waarin alle hulpverleningsinstellingen samenwerken. Alle instanties binnen het netwerk gaan na of zij informatie over de jongere hebben. Daarna wordt binnen het netwerk afgesproken welke stappen er met de jongere worden ondernomen en wie dat gaat doen" (Resp. A6) 5 .

\section{Huisbezoeken in het kader van het Sociaal Investeringsplan (SIP) in Overtoomse Veld}

Een laatste voorbeeld van de wijze waarop lokale autoriteiten proberen meer zicht te krijgen op de alledaagse problemen en belemmeringen van bewoners is het Sociaal Investeringsplan (SIP) in Overtoomse Veld. Het SIP startte in 2001 op initiatief van het stadsdeelbestuur van Slotervaart en diverse woningcorporaties. De achtergrond was ook hier de gedachte dat stedelijke vernieuwing hand in hand moet gaan met sociale investeringen voor bewoners. De vraag is echter wat bewoners nodig hebben. Het sip beoogt een 'vraaggerichte aanpak', in de zin dat bewoners een op hun individuele situatie en behoeften toegesneden pakket van steun en hulpverlening krijgen aangeboden. Om zicht te krijgen in de individuele behoeften is gekozen voor een huis-aan-huisaanpak. Alle bewoners van bepaalde woningcomplexen krijgen bezoek van een zogenaamde bewonersadviseur. Tijdens het huisbezoek vormt de bewonersadviseur zich een beeld van de situatie. Deze zoekt daarbij naar mogelijkheden om verbeteringen te realiseren op diverse gebieden zoals taalvaardigheid, onderwijs en opvoeding, sociale participatie, werk en inkomen, veiligheid, gezondheid of welzijn. Men probeert na te gaan wat de situatie van leden van het huishouden op de diverse terreinen is, of zij bepaalde behoeften hebben en of verbeteringen mogelijk zijn. De uitkomst van het bezoek kan zijn dat bewoners gestimuleerd worden een taalcursus te 
bezoeken, geholpen worden met het aanvragen van huursubsidie of schuldhulpverlening, doorverwezen worden naar diverse instanties, enz. ${ }^{6}$

\subsection{BUURTINTERVENTIES}

Ook in Amsterdam is men tot het inzicht gekomen dat de reactie van de lokale politiek op problematische stadsbuurten lang niet altijd optimaal is geweest. Al te vaak werden problemen en klachten van bewoners genegeerd of werd er te slap opgetreden. In Amsterdam-West speelde dit onder meer bij de aanpak van overlast veroorzakende Marokkaanse jongeren in de wijk. Na de rellen van 1998 kiest men echter ook voor een radicaal andere aanpak langs twee sporen. De nieuwe stadsdeelvoorzitter van Slotervaart, Henk Goettsch, licht dit tweesporenbeleid als volgt toe.

"Aan de ene kant repressief. Geen onnodig machtsvertoon in de zin van 'de wijk blauw verven', maar wel zoveel mogelijk aanhoudingen om criminaliteit tot landelijke proporties terug te brengen. Aan de andere kant moet de dialoog worden hersteld met de fracties in de wijk. Veel praten, nog meer luisteren, maar dan niet op de geitenwollensokkenmanier van de jaren tachtig. Niet pappen en nathouden, maar een combinatie van harde hand en zachte hand. Ingrijpen, maar ook een alternatief bieden. Een situatie creëren waarin iedereen wint."’

Een exemplarisch voorbeeld van de nieuwe, hardere aanpak van stedelijke problemen is de eerdergenoemde harde kernaanpak waarmee de gemeente Amsterdam veelvoorkomende jeugdcriminaliteit probeert te bestrijden. Maar ook op andere beleidsterreinen zien we de opkomst van meer gerichte aanpakken van sociale problemen, waarbij interventies in het leven van mensen niet uit de weg worden gegaan. Voorbeelden daarvan zijn:

- de aanpak van de harde kern van jeugdcriminaliteit;

- het betrekken van ouders van probleemjongeren bij het oplossen van problemen;

- het realiseren van 'voorscholen';

- het realiseren van een sluitende aanpak van voortijdig schoolverlaten.

\section{Harde kernaanpak jeugdcriminaliteit}

Centraal doel van de Amsterdamse harde kernaanpak is het verminderen van het aantal jongeren dat op grote schaal delicten pleegt. Men heeft hierbij niet de illusie dat deze criminele jongeren door een zachte pedagogische interventie of welzijnsactiviteiten op het rechte pad terechtkomen. Het belangrijkste middel om de harde kern te verminderen is het langdurig 'van de straat halen' of 'wegzetten' van criminele jongeren in justitiële inrichtingen of in resocialisatiecentra zoals Den Engh en de Glenn Mills school. Jongeren komen in de gevangenis terecht na een strafrechtelijke veroordeling door de rechter, in Den Engh en de Glenn Mills school komt men terecht na een civielrechtelijke procedure. In zulke gevallen heeft de Raad voor de Kinderbescherming onderzoek gedaan naar de betreffende jongere en aanbevolen dat een gezinsvoogd wordt benoemd. Gaat de 
jongere toch door met het plegen van delicten, dan kan de gezinsvoogd bij de rechter een verzoek tot uithuisplaatsing indienen, waarbij de jongere dan een jaar lang in een resocialisatiecentrum terecht kan komen. De gemeente Amsterdam heeft hiertoe een aantal plaatsen in deze centra voor jongeren uit de stad ingehuurd.

De Amsterdamse harde kernaanpak was in 2003 in zoverre succesvol dat in dat jaar in totaal 381 jongeren (deels licht crimineel, deels harde kern) in een jeugdinrichting zijn geplaatst. Daarnaast zijn nog eens 81 harde kernjongeren (onder wie circa 25 jongeren uit Amsterdam-Nieuwwest) in een resocialisatietraject zoals ITB18+, Den Engh of de Glenn Mills school geplaatst. Plaatsing in een resocialisatietraject betekent dat de jongere een jaar lang in een gesloten inrichting verblijft. De vraag is overigens wat de effecten hiervan zijn. Volgens de betrokken inrichtingen vallen maar weinig jongeren daarna weer terug in de criminaliteit, maar anderen zijn hiervan niet zo zeker. Zo betogen de criminologen Van Gemert en Fleisher (2002: 80), die onderzoek deden onder Marokkaanse jongeren in het naburige Osdorp, dat veel jongeren in oude fouten vervallen zodra ze weer in de buurt en bij hun oude vriendengroep terugkomen.

“Interventiemaatregelen hebben weinig effect gesorteerd. De jongens die werden opgepakt keren vaak terug naar de groep en hulpverleners slagen er niet in ze op het rechte pad te houden. De invloed van de groep is te groot en dat leidt tot de conclusie dat het rigoureus verbreken van de banden tussen individu en groep een noodzakelijk onderdeel moet zijn van interventies." 8

Zegslieden meenden cynisch dat de jongeren in ieder geval in het jaar dat ze weg zijn geen delicten kunnen plegen. Als deze jongeren inderdaad zoveel delicten plegen als wordt gedacht, dan scheelt dat aanzienlijk. Verder heeft men geleerd hoe belangrijk het is dat er een goede opvang en nazorg zijn voor jongeren die terugkomen in de buurt. Toen de eerste jongeren uit Amsterdam-West uit centra als Den Engh of Glenn Mills in de buurt terugkwamen, was er niets geregeld. Hierdoor ging het al snel weer fout.

"Het nadeel is dat de jongeren maar één jaar bij Den Engh of Glenn Mills blijven (door het contract dat de gemeente heeft afgesloten). Maar een jaar is gewoon te kort. Daarbij moet je van alles geregeld hebben als die jongeren weer terugkomen in de buurt, maar dat was dus niet zo. We weten van tevoren dat die jongens vrijkomen en dat er opvang en begeleiding geregeld moeten zijn, maar dat lukt dan niet. Dan zie je dat die jongens weer in de greep van hun vriendjes komen en dat het weer fout gaat" (Resp. A8).

"Inmiddels duurt het hele traject achttien maanden: ze zijn een jaar weg en daarna worden ze nog zes maanden begeleid in de buurt. Er is een nazorgtraject ontwikkeld voor jongeren die terugkomen uit Den Engh of Glenn Mills. Dat is nieuw. Bij de eerste lichting jongeren die terugkwam uit Den Engh was er onvoldoende nazorg. Dat is natuurlijk zonde. Als die jongeren niet worden opgevangen en weer gekke dingen gaan doen, is je hele investering voor niets geweest. Nu zijn er 
nazorgtrajecten, waarbij gekeken wordt naar huisvesting, werk of scholing, schulden - veel jongeren hebben forse schulden. Dat soort zaken wordt allemaal tegen het licht gehouden en geregeld” (Resp. A7).

\section{Het betrekken van ouders van probleemjongeren \\ De harde kernaanpak richt zich primair op jongeren die crimineel zijn of dat drei- gen te worden, daarnaast is er ook toenemende aandacht voor de ouders en gezinnen van jongeren. Het betrekken van ouders bij de aanpak van jeugdcrimi- naliteit is volgens zegslieden van groot belang.}

“Bij de aanpak van problematische jeugdgroepen is de politie samen met jongerenwerkers bij de ouders langsgegaan. Ze gaven een brief af met een uitnodiging om op een avond op het politiebureau te komen. Alle ouders zijn gekomen en toen is de hele problematiek van jeugdgroepen aan hen uitgelegd. Dat is voor die ouders echt een eye opener geweest, ze wisten niet dat hun kind daarvan deel uitmaakt” (Resp. A7).

“Je moet ouders helpen om hun kinderen beter op te voeden. Dat hoeft niet ingewikkeld te zijn, dat kunnen we hier binnen de politie zelf wel doen. We hebben daar wel ervaring mee. Zo constateerde een buurtregisseur dat het met een paar jongeren gewoon fout liep, rondhangen, drugsgebruik, af en toe kleine delicten. Een van de moeders van die jongeren kwam naar de buurtregisseur en vertelde dat ze haar zoon niet meer in de hand heeft. Een noodkreet, kun je me niet helpen? Dat komt heel vaak voor. Toen hebben we die ouders hier op het bureau uitgenodigd om hun verhaal te laten vertellen. Ouders zijn zich vaak niet bewust wat hun kinderen allemaal uitspoken op straat. Ze kennen hun kinderen alleen maar thuis, maar op straat of op school zijn ze vaak heel anders, dat weten ouders vaak niet. In de eerste plaats is het dus bewustwordingsproces, dat de ouders een completer beeld van hun kind krijgen. Daarbij doorbreek je het zwijgen. Als je met ouders in een groep over deze problemen praat, dan zien ze dat zij niet alleen zelf met dit probleem zitten maar andere ouders ook. In de derde plaats zie je dat ouders ook elkaar gaan ondersteunen, dat ze nog een keer bij elkaar komen. In de vierde plaats kunnen we nagaan wat we voor deze jongeren kunnen betekenen. Deze jongeren worden natuurlijk ook in het Netwerk 12+ besproken en dan is het de vraag of we bepaalde voorzieningen voor de jongere kunnen regelen, bijvoorbeeld een sportclub of iets anders" (Resp. A5).

Ook bij het bestrijden van schoolverzuim en voortijdig schoolverlaten worden ouders van kinderen harder aangepakt. Een van de redenen van schoolverzuim is dat kinderen te laat van vakantie terugkomen. De verantwoordelijke stadsdeelbestuurder noemt leerplichthandhaving een eerste voorwaarde om schoolverlaten tegen te gaan, maar vroeger was men daarin 'veel te slap'. Men startte een driejarenplan. In het eerste jaar kregen alle ouders van kinderen die te laat van vakantie terugkwamen een waarschuwing en in het tweede een sanctie. Wie in het derde jaar nog steeds te laat van vakantie terugkwam, kreeg een formele boete. Het aantal kinderen dat het begin van het schooljaar mist, is door deze hardere en normerende aanpak met meer dan de helft verminderd. ${ }^{9}$ 


\section{Voorscholen}

Een ander voorbeeld dat hardnekkige sociale problemen in de stad door een gerichte en forse interventie verminderd kunnen worden, is de voor- en vroegschoolse educatie (VVE). Dit initiatief is een rechtstreeks gevolg van onderzoek dat liet zien dat allochtone kinderen het niet zozeer slechter doen op de basisschool, maar hun schoolcarrière vaak beginnen met een grote achterstand (Tesser en Iedema 2001). Om hieraan iets te doen zijn zogenaamde 'voorscholen' ontwikkeld, meegefinancierd door het rijk, die zich richten op peuters en kleuters van 2 tot 6 jaar (in peuterspeelzalen en in groep 1 en 2 van de basisschool). Voorschoolse educatie beoogt door speciaal ontwikkelde programma's (Kaleidoscoop en Pyramide) de taal- en ontwikkelingsachterstand van kinderen van laagopgeleide ouders in een vroeg stadium aan te pakken om zo de startpositie in het basisonderwijs te verbeteren. Het gaat overigens niet alleen om allochtone, maar ook om autochtone kinderen uit achterstandsgroepen. In heel Nederland bestaat de doelgroep van voorschoolse educatie uit rond 200 duizend kinderen, waarvan naar schatting circa 15 duizend in Amsterdam. ${ }^{10}$

Volgens stadsdeelbestuurder Hoogerwerf liep het stadsdeel Slotervaart voorop met de voorschoolse educatie. Al in 1998 gingen hier de eerste twee voorscholen van start en inmiddels zijn vijf basisscholen in Slotervaart aangewezen als voorschool (Ru Paré, prof. Einstein, El Kadisia, St. Jan de Doper en Johan Huizinga). In totaal nemen ruim 600 peuters en kleuters deel aan voorschoolse educatie, van wie de meeste een allochtone herkomst hebben. Drie andere basisscholen werken wel volgens de VVE-methodieken, maar hier wordt de peutergroep - net als bij de voorscholen - door een welzijnsinstelling gerund. Op deze zogenaamde aandachtsscholen komen nog eens 450 peuters en kleuters in aanraking met VVE. In totaal nemen in het stadsdeel Slotervaart dus ongeveer 1050 kinderen deel aan een voorschool. ${ }^{11}$ Voorschoolse educatie vergt een aanzienlijke inzet van financiële middelen. Er zijn veel voorzieningen en hulpmiddelen (bijvoorbeeld computers) op de scholen en veel groepen worden dubbel bezet met leerkrachten en onderwijsassistenten. De financiering geschiedt mede vanuit het Gemeentelijk Onderwijs Achterstandenbeleid (GOA), daarnaast heeft ook het stadsdeel behoorlijk geïnvesteerd in voorschoolse educatie. ${ }^{12}$

Over de effecten van voorschoolse educatie in termen van de onderwijsprestaties van kinderen die het VVE volledig hebben doorlopen, is op het moment van schrijven weinig te zeggen.

\section{Sluitende aanpak voortijdig schoolverlaten}

Een laatste voorbeeld van een stevige interventie betreft de sluitende aanpak voortijdige schoolverlaten in Amsterdam-West. Zoals gezegd, heeft men in Amsterdam beter zicht op de groep voortijdige schoolverlaters dan in veel andere Nederlandse gemeenten. Alle jongeren die zonder minimale startkwalificatie van school zijn gegaan worden opgeroepen door een casemanager. Daarvan zijn er inmiddels vijf aangesteld. 
“Die gaat een gesprek aan en kijkt als eerste optie of terugkeer naar school mogelijk is, als tweede optie wordt gekeken naar een andere school, de derde optie is tijdelijk werk en de vierde optie is toeleiding naar vast werk (als naar school gaan echt niet haalbaar is). De bedoeling is dat jongeren gemonitord worden tot ze 23 jaar zijn. Ook wordt gekeken of ze toch nog een startkwalificatie kunnen halen. De gemeente kan niet garanderen dat alle jongeren een minimale startkwalificatie halen, want sommigen missen daartoe de capaciteiten. De gemeente kan zich wel verplichten om jongeren tot hun 23 ste jaar bij te staan om een startkwalificatie te halen" (Resp. A4).

Naast de vergroting van het aantal casemanagers is ook de afdeling leerplicht van het stadsdeel Slotervaart uitgebreid van één naar vijf fulltime krachten.

\subsection{VitALE COALITIES, INTEGRAAL WERKEN EN KETENAANPAK}

Vitale coalities, integraal werken en ketenaanpak zijn veelgehoorde trefwoorden bij de hedendaagse aanpak van stedelijke problemen in buurten als Overtoomse Veld. Ook in Overtoomse Veld struikelt men over de 'netwerken' en 'samenwerkingsverbanden' tussen alle mogelijke partijen. Voorbeelden hiervan zijn onder andere de diverse netwerken rondom jongeren, de brede scholen, het buurtbeheer, enzovoort. Binnen dergelijke netwerken treft men steeds weer dezelfde partijen: politie en justitie, het onderwijs, Bureau Jeugdzorg, de Raad voor de Kinderbescherming, vertegenwoordigers van het stadsdeelbestuur, woningbouwcorporaties en het welzijnswerk. Bij deze integrale aanpak van problemen kunnen echter twee kanttekeningen worden geplaatst.

In de eerste plaats valt op dat vooral 'publieke professionals' actief zijn binnen de vele samenwerkingsverbanden, mensen die werkzaam zijn bij de gemeente, de politie, justitie, het onderwijs, enz. Met andere woorden, er is in een stadsdeel als Slotervaart maar weinig particulier initiatief van burgers of bedrijven. Het probleem van dit soort achterstandswijken is dan ook dat burgers zich terugtrekken uit de publieke sfeer en dat particuliere partijen de buurt helemaal verlaten. Op deze tendens van passieve burgers zijn echter in Overtoomse Veld ook uitzonderingen. Twee voorbeelden daarvan zijn de Marokkaanse buurtvaders en het project 'En nu iets positiefs'. Deze voorbeelden zullen we kort bespreken.

De tweede kanttekening betreft de rol van het professionele welzijnswerk bij de aanpak van buurtproblemen. In de vorige decennia speelden welzijnswerkers vaak een zeer vooraanstaande rol in stadsbuurten als Overtoomse Veld, maar in de huidige initiatieven nemen zij nog slechts een marginale plaats in. Wat opvalt is dat de politie zeer actief is bij de aanpak van buurtproblemen en dat zij daarbij ook welzijnswerkachtige taken op zich neemt. Politiefunctionarissen vervullen een leidende rol bij projecten voor jongeren in de buurt, onderhouden contacten met ouders van probleemjongeren en meer algemeen met de diverse bevolkingsgroepen in de wijk. We gaan hierna eerst in op twee voorbeelden, die wel voortkomen uit particuliere initiatieven - met name uit de Marokkaanse gemeenschap - en bespreken vervolgens de relatie tussen de politie en het welzijnswerk. 


\section{Marokkaanse buurtvaders}

De Marokkaanse buurtvaders uit Overtoomse Veld zijn misschien wel het bekendste criminaliteitspreventieproject van Nederland. Het initiatief voor dit project werd na 'de rellen van 1998' genomen door bestuursleden van de Marokkaanse stichting Al Mawadda. De Marokkaanse vaders besloten dat ze zelf iets aan de veiligheid in de buurt wilden doen door jongeren op straat aan te spreken en waar nodig te corrigeren op hun gedrag. Er zijn inmiddels ruim 25 buurtvaders actief, met name in en rond de buurt Overtoomse Veld. Het zijn vrijwel allemaal getrouwde mannen met kinderen, van Marokkaanse komaf en tussen de 30 en 60 jaar oud. De meeste van hen werken, sommigen hebben een uitkering. Een buurtvader moet minstens twee avonden per week beschikbaar zijn. Op deze avonden lopen ze hun ronde in de buurt of zijn ze indien nodig oproepbaar. Tijdens hun ronde zoeken de buurtvaders contact met jongeren op straat. Indien de jongeren overlast veroorzaken, vragen de buurtvaders hen om rekening te houden met andere bewoners. In het begin trokken jongeren zich daarvan weinig aan, maar na verloop van tijd gaven jongeren vaker gehoor aan de verzoeken van de buurtvaders (De Jong en De Haan 200o) Het optreden van de buurtvaders is een typisch voorbeeld van informele sociale controle in de buurt, dat volgens criminologische onderzoek bevorderlijk is voor zowel de veiligheid in de buurt als de subjectieve veiligheidsbeleving van burgers. Volgens onderzoekers heeft het project goede effecten.

“Op basis van interviews met Marokkaanse jongeren in de buurt kan worden geconstateerd dat een belangrijk deel van hen het gezag van de buurtvaders accepteert en feitelijk ook rekening houdt met het toezicht dat door de buurtvaders wordt uitgeoefend. Enkele leden van de (voormalige) 'harde kern' hebben mede dankzij de buurtvaders werk gevonden of zijn een opleiding gaan volgen. Er zijn echter ook enkele respondenten die zich afzijdig houden en de goede bedoelingen van de buurtvaders in twijfels trekken." ${ }_{13}$

De onderzoekers constateren verder dat ze geen positieve effecten van het project hebben gemeten, maar dat ze op theoretische gronden wel denken dat het project een gunstig effect heeft op de overlast en criminaliteit van Marokkaanse jongeren in de buurt.

Professionals in de buurt waarderen de Marokkaanse buurtvaders vooral, omdat het project hen een toegang geeft tot de Marokkaanse gemeenschap in de buurt.

De stadsdeelbestuurder:

"De buurtvaders is een fantastisch initiatief, dat terecht allerlei prijzen heeft gekregen. Het zijn Marokkaanse vaders die zeggen: wij nemen verantwoordelijkheid voor de onveiligheid die mede door onze kinderen wordt veroorzaakt, door aanwezig te zijn, te signaleren en preventief bezig te zijn. Alleen al dat Marokkanen dit eens zelf zeggen en ook daarnaar handelen is geweldig. Maar als je kijkt wat ze feitelijk doen is dat niet zo heel veel. Ze zijn met 22 man die elkaar opzoeken en twee rondjes in de buurt lopen. Ze bellen elkaar en ze zijn erg goed als er ergens een probleem is. 
Als een school of een supermarkt problemen heeft met een paar Marokkaanse jongens, dan komen de buurtvaders twee ochtendjes en die lossen het probleem op. Dat is fantastisch, maar heeft weinig effect op de criminaliteitscijfers. Dan heeft de harde kernaanpak veel meer effect" (Resp.

A4).

\section{De buurtregisseur:}

"Ze zijn niet het ei van Columbus, maar het effect was wel dat een groep mannen vertrouwd raakte met de politie. Ik heb veel contact met ze, de politie is een belangrijke partner voor ze geworden. Als zij vonden dat de wijk verloederde, konden we daarover praten. Zo ontstond er een stukje toezicht op straat, dat ongetwijfeld wel effect had, al was het minimaal. Maar veel belangrijker was dat zij meewerken aan de leefbaarheid van de buurt. Defecte lantarenpalen, gaten in het wegdek, dat melden ze bij het stadsdeel. Verder fungeren ze als een intermediair tussen ons (de politie) en de buurt. Het zijn mensen met wie ik allerlei problemen in de buurt kan bespreken en die meedenken over de problemen in de buurt. Door de buurtvaders ontstaat een soort sneeuwbaleffect: de dingen die jij kwijt wil, worden via de buurtvaders in de buurt verspreid zonder dat er een taalbarrière is. Ze zitten ook in allerlei andere organisaties in de buurt, zoals de moskee. Dus als ik een probleem bij hen aankaart, kunnen ze ook zeggen: we vragen of de imam er ook aandacht aan wil besteden. Zo verspreiden ideeën zich in de buurt” (Resp. A8).

\section{'En nu iets positiefs'}

Een van de initiatieven van de Marokkaanse buurtvaders was het project 'En nu iets positiefs' (ENIP). Ook al spelen het stadsdeelbestuur en de buurtregisseur een sturende rol achter de schermen, dit project wordt vaak naar voren geschoven als hét voorbeeld van een particulier initiatief in de buurt.

\section{De buurtregisseur:}

"Het is een heel aansprekend preventief project, vooral omdat het wordt gedragen door de buurt. Het project is niet door de gemeente gedropt, maar wordt gedragen door de buurtvaders, de jongerenvereniging, mensen die met hun voeten in de modder staan. Het zijn mensen die weten wat er aan de hand is in de buurt, je hoeft ook niet oeverloos te praten" (Resp. A8).

\section{De coördinator jeugd van de politie in Amsterdam-West:}

"In Slotervaart kun je een enorme verbetering zien in de leefbaarheid. Mensen worden veel meer betrokken bij de buurt. De buurtvaders, een project als En nu iets positiefs zijn allemaal zaken waaruit je kunt aflezen dat de communicatie en dus de leefbaarheid in de buurt veel beter is geworden. Mensen hebben het gevoel dat ze meer grip op de situatie hebben en dat is op zich al belangrijk voor de leefbaarheid. Als je meent dat je greep hebt op de situatie, geeft dat op zichzelf al een gevoel van leefbaarheid” (Resp. A5). 
Het project is ontstaan als reactie op de aanhoudend negatieve berichtgeving over de wijk en haar Marokkaanse jongeren. Het initiatief voor het project werd genomen door de Marokkaanse buurtvaders, samen met de jongerenvereniging Oportuna, de welzijnsorganisatie Impuls, het stadsdeel, de politie in Amsterdam-West (de alomtegenwoordige buurtregisseur) en een private partij, Albert Heijn.

Het idee was een werkervaringsplaats te creëren voor Marokkaanse jongeren uit Amsterdam-West, die op het randje van criminaliteit staan. De jongeren verzamelen oude spullen en knappen die onder professionele begeleiding op, zodat ze kunnen worden opgestuurd naar sociale projecten in Marokko. De jongens zijn vier avonden per week op het project aanwezig: drie avonden werken ze, de vierde avond krijgen ze een cursus (bijvoorbeeld informatie over Marokko of een sociale vaardigheidstraining). Wie het traject afmaakt, mag als beloning mee naar Marokko om de spullen af te leveren bij een weeshuis of ziekenhuis. De achterliggende gedachte is mede dat jongeren door hun ervaring in Marokko leren dat het in Nederland zo slecht nog niet is.

ENIP is ook een voorbeeld van een vrij ingrijpende interventie in het dagelijks leven van jongeren. Het betekent nogal wat, dat ze vier avonden per week aanwezig moeten zijn (bij te veel afwezigheid vliegt men uit het project). Het project lijkt goede effecten te hebben. Jongeren die met de eerste ronde van het project meededen (inmiddels is het voor de tweede keer gestart), vertellen dat ze door het project en door vooral hun verblijf in Marokko op het goede pad zijn terechtgekomen en weer naar school gaan of zijn gaan werken. Eén voormalige deelnemer van het project vertelde dat hij inmiddels zelf als jongerenwerker werkt en probeert andere jongens in de buurt in het gareel te krijgen.

\section{Buurtnetwerken jeugd}

Ook het stadsdeel Slotervaart kent diverse netwerken die zich met jongeren bezighouden. Het belangrijkste netwerk is wel het netwerk $12+$ waarin jongeren met problemen besproken worden. Het gaat deels om criminele jongeren, maar ook om jongeren zonder politiecontacten die problemen hebben (zoals schoolverzuim of uitval). Het Netwerk $12+$ is een uitvloeisel van het jeugdveiligheidsplan in Slotervaart, dat onder meer een betere coördinatie van de jeugdhulpverlening beoogde. Binnen het netwerk fungeert een groot aantal partijen (scholen, welzijnswerk, jeugdzorg, reclassering, politie, justitie en andere relevante partijen). Doel van het netwerk is om tot een samenhangende aanpak van individuele jongeren en gezinnen te komen en te vermijden dat diverse instanties ieder op hun eigen manier bij deze jongeren c.q. hun gezinnen interveniëren.

De buurtregisseur benadrukt dat het netwerk op twee verschillende manieren werkt. Er zijn formele bijeenkomsten van het netwerk, maar belangrijker zijn wellicht de informele contacten tussen leden van het netwerk. Omdat men elkaar in het netwerk heeft leren kennen, kan men elkaar makkelijker raadplegen wanneer men met een bepaalde jongere te maken heeft. 
"Iemand brengt een bepaalde jongere in en dan zeggen alle partijen of ze die betreffende jongere kennen of onder behandeling hebben. Dan spreken we gezamenlijk af wat er met die jongere moet gebeuren. Bijvoorbeeld dat de reclassering of hulpverlening nu moet ingrijpen. Dan wil ik over twee weken horen wat er precies voor die jongere is georganiseerd. In de praktijk wacht ik dan niet twee weken, vaak bel ik al na een paar dagen op om te kijken of men al iets voor de jongere heeft gedaan. Je moet het vuurtje steeds opstoken” (Resp. A8).

Het meest opmerkelijke aan het netwerk $12+$ is de samenwerking tussen politie en justitie aan de ene en het professionele welzijnswerk aan de andere kant. Er wordt vaak gesproken over een kloof tussen beide instanties, die ieder hun eigen doelen en benadering hebben. De politie werkt veelal verplichtend, welzijnswerk op basis van vrijwilligheid. De politie wil regelovertreders opsporen en ter verantwoording roepen, welzijnswerkers hebben soms de neiging om hun cliënten in bescherming te nemen. Ook in Slotervaart waren er spanningen tussen de partijen. Zo hadden jongerenwerkers aanvankelijk weinig zin om mee te werken aan het in kaart brengen van problematische jeugdgroepen in de wijk, ze wilden geen 'verklikker' zijn. Stadsdeelbestuurder Hoogerwerf stelt kortweg: "Wij hebben de welzijnswerkers gedwongen om hieraan mee te werken."

Later bleek de samenwerking tussen politie en jongerenwerk beter te verlopen. Hoogerwerf:

"Als je het maar goed aanpakt. De afspraak is dat jongerenwerkers de politie adviseren, want je moet hen niet in de positie brengen dat ze als informant of verklikker optreden. Jongerenwerkers hebben goed zicht op hoe groepen in elkaar zitten, wie leiders en wie meelopers, met welke jongens je nog wat kan als je het goed aanpakt. Dat is heel goede informatie voor politie. Jongerenwerkers hebben er zelf ook belang bij dat raddraaiers die de boel verzieken uit een groep jongeren verwijderd worden" (Resp. A4).

De coördinator van het jongerenwerk in Slotervaart bevestigt dit.

"Jongerenwerkers kregen door dat het in hun eigen belang is dat problematische jongeren op een gegeven moment uit de groep gehaald worden. Daarna kun je veel beter werken met de groep." Zelf heeft hij geen probleem om de politie informatie te verschaffen over jeugdgroepen, maar vindt dat je geen specifieke delicten mag verklappen. Je moet ook je mond kunnen houden tegenover de politie (Resp. A7) $)^{14}$.

Ook buurtregisseur Smakman ziet geen kloof tussen politie en welzijnswerk.

"Ik vind dat we begrip hebben voor elkaars mogelijkheden en onmogelijkheden, juist omdat we allemaal hetzelfde willen. Bijvoorbeeld, in het netwerk $12+$ geven wij als politie precies aan wat we met een bepaalde jongere willen en waarom we dat willen. Daarmee geven we ook bouwstenen 
aan voor de collega van hulpverlening om naar zijn organisatie toe te verkopen wat we willen. Waarom voor een bepaalde jongere een bepaald hulpverleningstraject nodig is. Hulpverlening gaat natuurlijk altijd op basis van vrijwilligheid. Als een jongere niet wil, dan is het hulpverlening einde. Daarin moet je reëel zijn. Anders blijf je doktoren zonder kans op succes, zonde van je energie. Maar biedt een jongere die kans en vraag ook waarom hij niet wil. En je moet het ook verkopen naar die jongere toe, je moet het aantrekkelijk maken. Je moet jongeren duidelijk maken dat hulpverlening de uitkomst is om goed weg te komen uit de situatie waarin ze zitten. Het is hulpverlening of strafrecht...” (Resp. A8).

\subsection{SCHAALNIVEAUS}

Al met al kan men concluderen dat zowel de aard en omvang van de stedelijke problematiek in achterstandswijken in Amsterdam en Rotterdam als de aanpak van deze problemen in beide steden niet wezenlijk van elkaar verschillen. Toch is er een verschil in de politieke discussie over deze problemen in Rotterdam en Amsterdam. In Rotterdam wordt vaak gesproken over 'bovenmaatse' problemen die om bovenstedelijk ingrijpen vragen. Rotterdam vraagt enerzijds van de landelijke overheid een strenger immigratiebeleid en anderzijds van de randgemeenten meer betrokkenheid bij de opvang van nieuwkomers en kansarme groepen. Deze geluiden hoort men in Amsterdam niet. ${ }^{15}$ Integendeel, lokale bestuurders uit Amsterdam zijn de mening toegedaan dat men op de goede weg is om bestaande problemen op te lossen en dat een grotere spreiding van 'kansarmen' dus niet nodig is. Deze accentverschillen kunnen deels worden verklaard uit de verschillen in woonmilieus. Het meer aantrekkelijke woonmilieu van Amsterdam (ook als het gaat om de wijken buiten het centrum) voorkomt dat bepaalde stedelijke problemen ontstaan. Derhalve is er minder urgentie tot vergaande beleidsmaatregelen zoals selectieve vestiging en spreiding.

\subsection{DISCUSSIE}

Net als in de deelgemeente Charlois is de aanpak in de Overtoomse Veld een reactie op diverse leefbaarheids- en integratieproblemen zoals die de afgelopen decennia zijn ontstaan. Ook in Amsterdam wordt een zwaar accent gelegd op verbetering van de leefbaarheid en veiligheid. Bij de Amsterdamse aanpak kunnen twee kanttekeningen worden geplaatst. De eerste heeft, net als voor Charlois, betrekking op de werkgelegenheidssituatie. Dit blijft een nijpend punt voor de toekomst van de wijk. Het is cruciaal voor de vitaliteit van de wijk dat meer bewoners toegang krijgen tot de stedelijke arbeidsmarkt. Het huidige beleid van sociale herovering voorziet daar onvoldoende in. Het is ook typisch een beleid dat vorm dient te krijgen op stedelijk niveau.

Een tweede kanttekening heeft betrekking op de decentrale gerichtheid van beleid. Diverse problemen die het sociale leven in de Overtoomse Veld beïnvloeden, zijn van een bovenwijks en bovenstedelijk niveau. Men kan zich de vraag stellen of elementen van de Rotterdamse aanpak ook niet van belang zouden kunnen zijn voor het verbeteren van de sociale structuur en samenhang in Overtoomse Veld. 


\section{NOTEN}

$1 \quad$ Resp. A5: Coördinator Jeugd, Politie Amsterdam-Amstelland, District 6.

2 Over de aanpak van verschillende soorten jeugdgroepen, zie: J. Noorda e.a. (2003), Osdorpse lieverdjes. Groepsgerichte aanpak van overlast en criminaliteit. Amsterdam: Instituut Jeugd en Welzijn (vu). Verder: Politie District 6, Plan Jeugd en Veiligheid 2003.

3 Schatting van Resp. A7: Coördinator Justitie in de Buurt (JIB) in AmsterdamWest (interview).

$4 \quad$ Uitspraken van buurtregisseurs Smakman en Los in Slotervaart/Overtoomse Veld, geciteerd in De Groene Amsterdammer. Resp. A6: Interim-hoofd leerplicht RMC, Stadsdeel Slotervaart, en anderen.

6 Stadsdeel Slotervaart, Achter de deur. Investeren in mensen: Sociaal Investeringsplan Overtoomse Veld 2001; De tien gouden regels, jaarverslag Investeren in mensen: Sociaal Investeringsplan Overtoomse Veld 2002.

$7 \quad$ Geciteerd in De Groene Amsterdammer, 20 december 2003.

8 F. van Gemert en M. Fleisher (2002), In de greep van de groep. Een onderzoek naar een Marokkaanse problematische jeugdgroep. Amsterdam: Regioplan, p. 8o. Interview Resp. A4.

10 Gegevens: SCP (2003: 145); O\&S, De staat van de stad 2003, p. 55. Gegevens: Stadsdeel os, Naar een solide basis voor de allerjongsten. Naar een sluitende aanpak voor de o-6 jarigen in het stadsdeel Slotervaart/Overtoomse Veld, 2003-2006, p. 21 en 23.

12 Interview Resp. A4.

13 J.D. de Jong en W. de Haan (200o), 'Buurtvaders'. In Tijdschrift voor Criminologie, vol. 42 (200o), afl. 4, p. 390.

14 Resp. A7: Coördinator ambulant jongerenwerk, Stichting Impuls.

15 Integendeel, toen het Rotterdamse gemeentebestuur vroeg om een stop op de komst van kansarme groepen naar de stad, stelde de toenmalige Amsterdamse wethouder Oudkerk publiekelijk dat kansarmen in Amsterdam welkom zijn. 


\section{SAMENVATTING EN DISCUSSIE}

\subsection{INLEIDING}

De vraag naar de betekenis van lokale gemeenschappen en de corresponderende vraag hoe revitalisatie van lokale, sociale verbanden mogelijk is, zijn terugkerende vragen in wetenschap en politiek. Er is een lange sociaal-wetenschappelijke traditie waarin zorgen worden uitgesproken over het verval van gemeenschapsrelaties. De beroemde studie van Robert Nisbet, The Quest for Community (1953), is alleen al om zijn titel tijdloos en universeel. Indien zich belangrijke maatschappelijke verschuivingen voordoen, keren de bovenstaande vragen terug (Bauman 2001 en 2004). Het is daarom niet verrassend dat onder invloed van processen van globalisering en individualisering de vraag naar de sociale samenhang in buurten en wijken opnieuw wordt opgeworpen. Dat geldt in het bijzonder voor die gebieden waar fundamentele maatschappelijke veranderingen zich in uitvergrote vorm voordoen en waar als gevolg daarvan grote maatschappelijke problemen bestaan.

In deze studie is verslag gedaan van de processen en problemen die spelen in twee stedelijke gebieden in Amsterdam en Rotterdam en van de manieren waarop lokale bestuurders in samenwerking met gemeentelijke diensten, bewoners en private partijen proberen de leefbaarheid en vitaliteit van deze gebieden te verbeteren. Daarbij hebben we geconstateerd dat, ondanks de verschillen die er bestaan tussen Amsterdam en Rotterdam, een gemeenschappelijke aanpak zichtbaar wordt. Die aanpak is door ons geduid met het begrip 'sociale herovering'. Het gebruik van dit begrip wil niet zeggen dat 'sociale herovering' gerealiseerd is. Dat is vaak niet het geval. Sociale herovering staat voor een proces van verbetering van de leefbaarheid en samenhang in achterstandsbuurten. In deze samenvattende paragraaf benoemen we de centrale dimensies van sociale herovering (paragraaf 2) en stellen we vervolgens een aantal aspecten daarvan ter discussie.

\subsection{SOCIALE HEROVERING IN AMSTERDAM EN ROTTERDAM}

Sociale herovering staat voor het ontwikkelen van sociale en fysieke interventies gericht op (1) het vergroten van de leefbaarheid en veiligheid in de publieke ruimte; (2) het realiseren van een meer evenwichtige samenlevingsopbouw (in concreto: het aantrekken dan wel behouden van middengroepen) en (3) het formuleren van gemeenschappelijke competenties en gedragsregels om het alledaagse verkeer tussen bewoners te bevorderen (vgl. ook Reijndorp 2004). Sociale herovering vindt plaats in die gebieden waarvan betrokken partijen van mening zijn dat een kritische grens is overschreden. Duidelijk is echter dat de bepaling van die kritische grens niet louter gebaseerd is op objectieve criteria, maar dat ook spraakmakende incidenten, alsmede het vermogen van bewoners en politici om de urgentie van hun wijk op de kaart te zetten, daarin een rol spelen. Het beleids- 
offensief van 'sociale herovering' kan nader worden geduid aan de hand van vier typerende kenmerken.

- Een eerste kenmerk van sociaal heroveren is het herontdekken van sociale problemen die in bepaalde gebieden spelen. Dit proces van herontdekking is vooral zichtbaar bij die (semi-)publieke diensten die ooit zijn benoemd als street-level bureaucratieën (Lipsky 1980). Het gaat daarbij om diensten die in direct contact staan met bewoners, maar die in de afgelopen jaren sterk zijn gebureaucratiseerd. Hun relaties met klanten zijn vooral van administratieve aard en hun professionele bindingen met straten en wijken zijn losser en anoniemer geworden. Daardoor hebben deze diensten de greep op de stedelijke werkelijkheid deels verloren en zijn ze minder street wise geworden. $\mathrm{Nu}$ vindt echter een duidelijke ontbureacratisering plaats van deze diensten en pogen ze weer greep te krijgen op de alledaagse werkelijkheid zoals die zich op straat afspeelt en achter de façades van woningen en bedrijven.

- Een tweede kenmerk van sociaal heroveren is de intrusive aanpak. Deze indringende aanpak vloeit deels uit de herontdekking van sociale problemen voort. Om stedelijke problemen in de greep te krijgen wordt een indringende aanpak gehanteerd om ongewenste ontwikkelingen in de stedelijke samenleving direct te signaleren en te bestrijden. Vergaande interventies in het publieke domein en in de private sfeer worden daarbij niet geschuwd. Bestandskoppeling, cameratoezicht, preventief fouilleren en resocialisatieprogramma's voor jongeren zijn daar voorbeelden van. Andere voorbeelden hebben betrekking op allerhande initiatieven die gericht zijn op het formuleren van gedeelde waarden en normen in de stad en op school (stads- en schooletiquette). Deze voorbeelden maken tevens duidelijk dat de indringende aanpak tegelijkertijd een sterk normerende aanpak is. Het gaat niet alleen om een betere handhaving van normen, het gaat ook om het opleggen van een aantal basale normen waarvan verondersteld wordt dat zij het samenleven van bewoners ten goede komen (vgl. inburgeringsbeleid). Over de aard van deze normen wordt echter permanent strijd geleverd. Toch tekent zich in Amsterdam en Rotterdam een lokaal beschavingsoffensief af, met name in het veiligheids- en integratiebeleid, waarbij geprobeerd wordt om deze normen te formuleren en te handhaven (vgl. Van den Brink 2004).

- Een derde kenmerk is het tot stand brengen van een samenhangende aanpak van problemen waarbij diverse partijen betrokken zijn. Integraal beleid is altijd als een belangrijke voorwaarde gezien voor succesvolle interventies, maar is in de praktijk lastig te realiseren. Nu zien we geslaagde vormen van een integrale aanpak waarbij diverse publieke en private partijen effectief met elkaar samenwerken. Met name op terreinen als stedelijke herstructurering, bestrijding van illegale bewoning en het voorkomen van schooluitval van jongeren worden concrete successen geboekt. 
- Een vierde kenmerk van sociaal heroveren is de onderkenning van het belang van hogere en lagere schaalniveaus om beleidssuccessen te boeken (Gurr en King 1987). De problemen die spelen in de Tarwewijk of Slotervaart zijn niet op te lossen op de schaal van een stad of een stadsdeel. Er is een bovenstedelijk beleid nodig om de problemen die spelen in wijken het hoofd te bieden. Daarbij gaat het vooral om vraagstukken van internationale migratie, huisvesting en werkgelegenheid. Zij vragen om een nationaal of regionaal beleid. Anderzijds is er aandacht nodig voor lagere schaalniveaus zoals straten, huizenblokken en delen van buurten die, gelet op hun sociaal-economische structuur en cultuur, om een heel specifieke aanpak vragen.

\section{$7 \cdot 3$ DISCUSSIE}

Stedelijk beleid is geen oorlog. Zo geformuleerd is de metafoor van 'sociale herovering' misleidend. Wel wordt in deze metafoor de ernst van sociale problematiek in een aantal wijken tot uitdrukking gebracht, alsmede de directe, offensieve aanpak van problemen. In sommige delen van wijken is de sociale samenhang zodanig uit elkaar gevallen en is de leefbaarheid zodanig in het gedrang gekomen dat 'het sociale' weer heroverd moet worden. Het 'sociale' heeft dan vooral betrekking op het veilig maken van publieke ruimten, op het handhaven van rechtsregels en gedragsregels, en op het bijbrengen van normen en competenties (bijvoorbeeld taal), opdat bewoners in staat zijn vreedzaam met elkaar te kunnen samenleven. Het begrip 'sociaal heroveren' heeft een verwantschap met het begrip 'beschavingsoffensief' (Van den Brink 2004). Maar in geval van sociaal heroveren gaat het bovenal om het corrigeren van zaken die uit de hand gelopen zijn, terwijl in de analyse van Van den Brink (Janssen 2004) het vooral gaat om 'pre-pressie': ingrijpen voordat de zaken fout gaan. Daarnaast heeft de beleidsstrategie van sociale herovering niet alleen betrekking op het formuleren en handhaven van normen, maar ook op het tot stand brengen van een meer gevarieerde woningvoorraad. Wel ligt aan deze beleidsverandering het normatief idee ten grondslag dat een meer gevarieerde samenlevingsopbouw (van lage en hogere inkomensgroepen) gunstig uitwerkt op de stabiliteit van de sociale structuur van wijken.

De beleidsstrategie van sociale herovering maakt duidelijk dat het oplossen van stedelijke problemen in achterstandswijken niet louter door de bewoners zelf kan geschieden. Er is een vernieuwend decentraal én bovenstedelijk beleid nodig. De recente Rotterdamse voorstellen voor een bovenstedelijk migratie- en huisvestingsbeleid, zijn, los van de onjuiste beeldspraak die in de publieke opinie is gehanteerd ('een hek rond Rotterdam'), de moeite waard om nader uit te werken. De vraag is echter in hoeverre een dergelijk vestigings- en spreidingsbeleid daadwerkelijk gerealiseerd kan worden. Men zal bedacht moeten zijn op ongewenste effecten (bijvoorbeeld toename van illegale vestiging) en op de begrensde medewerking van randgemeenten en woningbouwcorporaties om kansarme groepen te bedienen (Veldboer en Duyvendak 2004: 49). Ook dient men zich rekenschap te geven van de stigmatiserende werking van de Rotterdamse voorstellen 
(vgl. Squires 1990). Het selectieve vestigingsbeleid wordt ook wel beschouwd als een 'allochtonenstop' en kan relaties tussen autochtone en allochtone bewoners en tussen Rotterdamse bestuurders en migrantengroepen doen verslechteren. Ook het voeren van een inburgeringbeleid zonder begrip voor de betekenis van andere culturen en identiteiten kan tot polarisatie leiden.

Een thema dat onvoldoende terugkeert in de aanpak van 'sociale herovering' is het vraagstuk van arbeid en participatie. Kwetsbare wijken tellen nog immer substantiële aantallen uitkeringsgerechtigden. De stedelijke arbeidsmarkten van Amsterdam en Rotterdam genereren echter onvoldoende banen voor de lokale beroepsbevolking (Van der Aa et al. 2003). Het is derhalve cruciaal om opnieuw na te denken over de betekenis van additionele arbeid voor die groepen die voorbij de arbeidsmarkt staan (vgl. Blok 2004). Wil het huidige beleidsoffensief van sociale herovering slagen, dan moet niet alleen de veiligheid en leefbaarheid versterkt en de woningvoorraad veranderd worden, maar dient ook de maatschappelijke positie van bewoners verbeterd te worden. De beleidsstrategie van additionele arbeid heeft vooral in het eerste paarse kabinet veel aandacht gekregen, maar er wordt nu op bezuinigd. Meer mogelijkheden tot het verrichten van additionele arbeid zouden de effectiviteit van het huidige beleid van sociale herovering kunnen versterken. Daarnaast blijft het van groot belang dat gewerkt wordt aan structuurveranderingen in de stedelijke economie. Er moet meer werk komen in de stad. 


\section{LITERATUUR}

Aa, P. van der, N. van der Giesen, A. Hekelaar, I.P.M. Libregts en M. van Toorn (2003) In de ban van de baan. Eerste resultaatmeting rë̈ntegratiebeleid Rotterdam. Rotterdam: Dienst Sociale Zaken en Werkgelegenheid.

Aalbers, M. (2003) Redlining in Nederland: Oorzaken en gevolgen van uitsluiting op de hypotheekmarkt. Amsterdam: Aksant.

Aalbers, M. (2004) 'Als de banken zich terugtrekken nemen de speculanten het over. Woningmarkt drugsmarkt en migranten in de Rotterdamse Millinxbuurt'. In: Agora, 20 (3) 2004.

Bauman, Z. (2001) Community: seeking safety in an insecure world. Cambridge: Policy Press.

Bauman, Z. (2004) Identity. Cambridge: Policy Press.

Beke, B., A. van Wijk en H. Ferwerda (200o) Jeugdcriminaliteit in groepsverband ontrafeld: tussen rondhangen en bendevorming. Amsterdam: SWP.

Blok, S.A. (2004) Bruggen bouwen. Den Haag: Sdu Uitgevers.

Blokland-Potters, T. (1998) Wat stadsbewoners bindt: Sociale relaties in een achterstandswijk. Kampen: Kok Agora.

Botman, S. en R. van Kempen (2001) The spatial dimensions of urban social exclusion and integration: the case of Rotterdam, the Netherlands. Amsterdam: AME, URBEX 19.

Botman, S. en R. van Kempen (2002) 'Improving Dutch neighbourhoods: Tarwewijk and Hoogvliet in Rotterdam'. In: C. Kesteloot (ed.) Urban Territorial Policies and their Effects at the Neighbourhood Level. Amsterdam: AME, URBEX 21, 78-85.

Brink, G. van den (2004) Schets van een beschavingsoffensief. Amsterdam: Amsterdam University Press.

Burgers, J. en G. Engbersen (1994) ‘De wrok van Spangen’. In: Psychologie en Maatschappij, jrg. 18, nr. 4, 1994, pp. 292-302.

Burgers, J. en S. Musterd (2002) 'Naar een verklaring voor stedelijke ongelijkheid: Een model gebaseerd op bestaande theorieën en een empirische illustratie'. In: Sociologische Gids, vol. 49 (2002), nr. 4, pp. 371-385.

Cohen, A. (1985) The Symbolic Construction of Community. Londen: Routledge.

Crisis Onderzoek Team (200o) Een drugsscene op Zuid (de Millinxbuurt). Een model voor de strategische analyse van drugsscene. Alphen aan den Rijn: Samsom.

Dagevos, J., M. Gijsberts en C. van Praag (red.) (2003) Rapportage minderheden 2003: onderwijs, arbeid en sociaal-culturele integratie. Den Haag: Sociaal en Cultureel Planbureau.

Desmet, E., P. Huiskens en A. Sour (2003) Op je Klompen. Hoe nieuw leven in te blazen in een oude stadswijk. Den Haag: Drukkerij H\&W.

Dieleman, F.M. en R.C. Kloosterman (200o) 'Room to manoeuvre; Governance, the Post-industrial economy, and Housing provision in Rotterdam.' In: M. Polèse en R. Stren, The Social Sustainability of Cities. Diversity and the Management of Change. Toronto: University of Toronto Press, pp. 175-202.

Doorn, J.A.A. (1955) 'Wijk en stad, reële integratiekaders?' In: Preadviezen voor het congres over sociale samenhangen in nieuwe stadswijken, gehouden op $17 \mathrm{decem-}$ ber 1955 te Amsterdam. Amsterdam: ISONEvo. 
Duyvendak, J.W. en P. van der Graaf ( 2001) Opzoomeren, stille kracht? Utrecht: VerweyJonker Instituut.

Duyvendak, J.W. en M. Hurenkamp (red.) (2004) Kiezen voor de kudde. Lichte gemeenschappen en de nieuwe meerderheid. Amsterdam: Van Gennep.

Engbersen, G. en R. Gabriëls (red.) (1995) Sferen van integratie. Amsterdam: Boom.

Engbersen, G., J.C. Vrooman en E. Snel (2000) Arm Nederland: balans van het armoedebeleid; vijfde jaarrapport armoede en sociale uitsluiting. Amsterdam: Amsterdam University Press.

Engbersen, G. (2003) 'De armoede van sociaal kapitaal'. In: Economisch-Statistische Berichten, vol. 88 (2003), 4398, p. Di2.

Engbersen, G. en J. Burgers (red.) (2001) De verborgen stad: de zeven gezichten van Rotterdam. Amsterdam: Amsterdam University Press.

Fischer, C.S. (1996) Inequality by design: cracking the bell curve myth. Princeton: Princeton University Press.

Fogteloo, M. van en E. van Holst Pellikaan (2003) 'August Allebépleinvrees'. In: De Groene Amsterdammer, 20 december 2003.

Fortuyn, W.S.P. (1987) Nieuw Rotterdam: een opdracht voor alle Rotterdammers: rapport van de Adviescommissie Sociaal Economische Vernieuwing Rotterdam. Rotterdam: Adviescommissie Sociaal-Economische Vernieuwing Rotterdam.

Fukuyama, F. (1996) 'Trust'. In: Current, (1996), afl. 379 (o1 o1), p. 12 (7).

Gemeente Amsterdam (2002) Alleen het resultaat telt: College-akkoord 2002-2006. Amsterdam: Gemeente Amsterdam.

Gemeente Amsterdam (2004) Wat Amsterdam beweegt. Sociaal Structuurplan Amsterdam 2004-2015 (concept). Amsterdam: Gemeente Amsterdam.

Gemeente Rotterdam. College van Burgemeester en Wethouders (2002) Het nieuwe elan van Rotterdam. .. en zo gaan we dat doen: collegeprogramma 2002-2006. Rotterdam: Het College van Burgemeester en Wethouders.

Gemeente Rotterdam. Bestuursdienst (2003) Rotterdam zet door: op weg naar een stad in balans. Rotterdam: Gemeente Rotterdam.

Gemeente Rotterdam (2004) Veiligheidsindex 2004. Meting van de veiligheid in Rotterdam. Rotterdam: Gemeente Rotterdam.

Gemeente Rotterdam (2004a) Rotterdam zet door: definities en begrippen.

Gemert, F. van en M. Fleisher (2002) In de greep van de groep. Een onderzoek naar een Marokkaanse problematische jeugdgroep. Amsterdam: Regioplan, p. 19-20, 80.

Groeneveld, S.M. en Y. Weijers-Martens (2003) Minderheden in beeld. SVPA-O2. Rotterdam: Instituut voor Sociologisch-Economisch Onderzoek (ISEO).

Gurr, T. R. en D.S. King (1987) The State and the City. Londen: Macmillan.

HP/De Tijd (2003) 'Het buitenland van Zuid'. In: HP/De Tijd, 19 september 2003.

Idenburg P.A. (1989) Het nieuwe Rotterdam in sociaal perspectief: rapport van de Commissie Sociale Vernieuwing. Rotterdam: Commissie Sociale Vernieuwing.

Janssen C. (2004) 'Voorbij het cynisme: Interview Gabriël van den Brink'. In: de Volkskrant, 19 juni 2004, p. 15.

Jong, J.D. de en W. de Haan (200o) 'Buurtvaders'. In: Tijdschrift voor Criminologie, vol. 42 (200o), afl. 4, p. 383-393 (11).

Kempen, E. van, i.s.m. S. Kamp (2003) Neighbourhood Governance Capacity for Social 
Integration. The Dutch case study: Overtoomse Veld. Amsterdam: Department of Geography and Planning.

Kleinhans, R.J. en H.M. Kruythoff (2002) Herstructurering: in het spoor van de vertrekkers. Een exploratief onderzoek naar de ervaringen van herstructureringsurgenten uit Hoograven (Utrecht) en Morgenstond (Den Haag). DGW/Nethur Partnership nr. 18, Delft/Den Haag.

Kleinhans, R.J. (2003) 'Displaced but still Moving Upwards in the Housing Career? Implications of Forced Residential Relocation in the Netherlands.' In: Housing Studies, vol. 18, no. 4, pp. 473-499.

Kloosterman, R. (1996) 'Polarization Trends in Amsterdam en Rotterdam after 1980'. In: Regional Studies, vol. 30 (1996), afl. 5 (o1 o8), p. 467 (10).

Komter, A., J. Burgers en G. Engbersen (2000) Het cement van de samenleving. Een verkennende studie naar solidariteit en cohesie. Amsterdam: Amsterdam University Press.

Leerkes, A., M. van San, G. Engbersen, M. Cruijff en P. van der Heijden (2004) Wijken voor illegalen. Over ruimtelijke spreiding, huisvesting en leefbaarheid. Den Haag: Sdu Uitgevers.

Leun, J.P. van der, E. Snel en G. Engbersen, 'Ongelijkheid in veiligheid. Achterstandsbuurten en criminaliteit'. In: Tijdschrift voor Criminologie, 40: 370-384.

Muller, E.R. (1998) Incident en ongeregeldheden Amsterdam West, 23 april 1998: Marokkaanse jongeren, politie en bestuur. Alphen aan den Rijn: Samsom.

Musterd, S., W. Ostendorf en S. de Vos (2001) Armoedeconcentraties en sociale effecten in dynamisch perspectief: de relatieve concentratie van huishoudens met een zwakke sociaal-economische positie en de effecten daarvan op hun sociale mobiliteit: de ontwikkeling tussen 1989 en 1994. Amsterdam: Instituut voor Stedelijk Onderzoek en Ruimtelijk Beleid.

Nisbet, R.A. (1953) The Quest for Community. New York: Oxford University Press.

Putnam, R.D. (2000) Bowling Alone. The Collapse and Revival of American Community. New York: Simon \& Schuster.

Reijndorp, A. (2004) Stadswijk, stedenbouw en dagelijks leven. Rotterdam: Nai Uitgevers.

Sassen, S. (1991) The Global City: New York, London and Tokyo. Princeton: University Press.

Sassen, S. (ed.) (2002) Global Networks, Linked Cities. Brunner-Routledge.

Schuyt, C.J.M. (1991) 'Wat sociale vernieuwing zou kunnen zijn'. In: C.J.M. Schuyt, Het hart van de verzorgingsstaat, Leiden/Antwerpen: Stenfert Kroese, pp. 79-9o.

Schrijer, D. (2003) 'Het gaat onze draaglast te boven. Een noodkreet uit de lokale praktijk.’ In: Socialisme \& Democratie, nr. 10/11, pp. 56-64.

Schrijer, D. en J. Dijsselbloem (2004) ‘Stop toestroom Antillianen’. In: de Volkskrant, 6 juli 2004.

SCP (2002) Sociaal en cultureel rapport 2002: De kwaliteit van de quartaire sector. Den Haag: Sociaal en Cultureel Planbureau.

Snel, E., B. Steijn en L. van der Laan (2001) 'Veranderende klassen in stedelijke economieën: Rotterdam en Amsterdam vergeleken’. In: G. Engbersen en J. Burgers (red.), De verborgen stad. De zeven gezichten van Rotterdam. Amsterdam: Amsterdam University Press, pp. 29-42. 
Sprinkhuizen, A., P. Vlaar, R. Engbersen en J. de Wild (1998) In de ban van de buurt. Over lokaal sociaal beleid in de buurt. Utrecht: NIZW 1998.

Squires, P. (1990) Anti-Social Policy. Welfare, Ideology and the Disciplinary State. New York: HarvestyerWheatsheaf.

Steijn, A.J., F.G. Snel en L. van der Laan (2000) ‘Een postindustriële klassenstructuur?: het klassenschema van Esping-Andersen toegepast op Nederland, Amsterdam en Rotterdam'. In: Sociologische Gids: maandblad voor sociologie en sociaal onderzoek, vol. 47 (200o), afl. 2 (mrt-apr), p. 77-94.

Tesser, P. en J. Iedema (2001) Rapportage minderheden 20o1. Deel 1 Vorderingen op school. Den Haag: SCP.

Veldboer, L. en J.W. Duyvendak (2004) 'Wonen en integratiebeleid: een gemengd beeld'. In: Sociologische Gids, jrg. 51, no. 1, pp. 36-52.

Vuijsje, H. (2004) 'What works': Rotterdam en stedelijke vernieuwing. Verslag Breed Beraad gehouden op 13 en 14 februari 2004. S.1.: Stichting Forum voor Stedelijke Vernieuwing.

Wouden, R. van de, E. de Bruijne en K. Wittebrood (2001) De stad in de omtrek. Problemen en perspectieven van de vier grootstedelijke gebieden in de Randstad. Den Haag: SCP. 


\section{BIJLAGE: LIJST RESPONDENTEN}

\section{Geïnterviewde personen Amsterdam, stadsdeel Slotervaart}

Resp. A1: G. Brinkman, RMC-coördinator Amsterdam-West (diverse stadsdelen)

Resp. A2: Mw. Buschmann, Professor Johan Huizingaschool

Resp. A3: M. Hasic, coördinator zelforganisaties, stadsdeel Slotervaart tevens buurtbeheer in de buurt Delflandplein/Staalmanplein

Resp. A4: H. Hoogerwerf (CDA), lid van dagelijks bestuur van het stadsdeel Slotervaart, portefeuille: Onderwijs, Welzijn, Buurtbeheer, Werk, Burgerzaken, Personeelszaken

Resp. A5: P. Immel, coördinator Jeugd, Politie Amsterdam-Amstelland, District 6

Resp. A6: L. de Jong, interim-hoofd leerplicht RMC, Stadsdeel Slotervaart

Resp. A7: J. Louwe Kooijmans, coördinator ambulant jongerenwerk, Stichting Impuls

Resp. A7: J. van Midden, coördinator 'Justitie in de Buurt'(JIB), Amsterdam-Nieuwwest

Resp. A8: T. Smakman, buurtregisseur, Politie Amsterdam-Amstelland, District 6

Resp. A9: M. van Thienen, Programmamanager Stedelijk Verbeterprogramma Leerplicht, gemeente Amsterdam

Resp. A1o: I. de Wilde, opbouwwerker Stichting Eigenwijks

Resp. A11: D. de Wit, procesmanager stedelijke vernieuwing, stadsdeel Slotervaart

\section{Geïnterviewde personen Rotterdam, deelgemeente Charlois}

Resp. R1: A. Brand, hoofd Sociale Wetenschappelijke afdeling Dienst Sociale Zaken Rotterdam

Resp. R2: H. Breeveld, directeur Stichting WelzijnsBevordering Antillianen/Arubanen

Resp. R3: E. Goyvaerts, directeur Transfer Informatie Punt, Charlois

Resp. R4: R. Kleinhans, onderzoeker Stedelijke Vernieuwing, Onderzoeksinstituut Отв

Resp. R5: A. Koster, laanmanager en projectleider interventieteams, Charlois

Resp. R6: M. van Muijen, buurtbewoner Charlois, gemeenteraadslid (PvdA) Rotterdam

Resp. R7: L. Pas, buurtbewoner, buurtconciërge, Charlois

Resp. R8: D. Schrijer (PvdA), dagelijks bestuurder deelgemeente Charlois, portefeuillehouder Ruimtelijke Ontwikkeling, Beheer \& Wijkzaken

Groepsbijeenkomst met aanwezigen: Resp. R9: J. Verschoor; directeur Beatrixschool en Resp. Rio: J. Kypriotakis; adjunct-directeur Beatrixschool, Resp. R8: D. Schrijer; dagelijks bestuurder deelgemeente Charlois, Resp. Rı1: J. Koelewijn; beleidsmedewerker Jeugd, Onderwijs en Cultuur, Resp. R12: D. Lockhorst; voorzitter deelgemeente Charlois, Resp. R13: J. van der Poel; deelgemeentesecretaris Charlois en Resp. Ri4: C. Beaton; wijkcoördinator Pendrecht. 


\section{RAPPORTEN AAN DE REGERING}

\section{Eerste raadsperiode (1972-1977)}

1 Europese Unie

2 Structuur van de Nederlandse economie

3 Energiebeleid

Gebundeld in één publicatie (1974)

4 Milieubeleid (1974)

5 Bevolkingsgroei (1974)

6 De organisatie van het openbaar bestuur (1975)

7 Buitenlandse invloeden op Nederland: Internationale migratie (1976)

8 Buitenlandse invloeden op Nederland: Beschikbaarheid van wetenschappelijke en technische kennis (1976)

9 Commentaar op de Discussienota Sectorraden (1976)

10 Commentaar op de nota Contouren van een toekomstig onderwijsbestel (1976)

11 Overzicht externe adviesorganen van de centrale overheid (1976)

12 Externe adviesorganen van de centrale overheid (1976)

13 Maken wij er werk van? Verkenningen omtrent de verhouding tussen actieven en niet-actieven (1977)

14 Interne adviesorganen van de centrale overheid (1977)

15 De komende vijfentwintig jaar - Een toekomstverkenning voor Nederland (1977)

16 Over sociale ongelijkheid - Een beleidsgerichte probleemverkenning (1977)

Tweede raadsperiode (1978-1982)

Etnische minderheden (1979)

A. Rapport aan de Regering

B. Naar een algemeen etnisch minderhedenbeleid?

Plaats en toekomst van de Nederlandse industrie (1980)

Beleidsgerichte toekomstverkenning

Deel 1: Een poging tot uitlokking (1980)

Democratie en geweld. Probleemanalyse naar aanleiding van de gebeurtenissen in Amsterdam op 30 april 1980

Vernieuwingen in het arbeidsbestel (1981)

Herwaardering van welzijnsbeleid (1982)

Onder invloed van Duitsland. Een onderzoek naar gevoeligheid en kwetsbaarheid in de betrekkingen tussen Nederland en de Bondsrepubliek (1982)

Samenhangend mediabeleid (1982)

\section{Derde raadsperiode (1983-1987)}

Beleidsgerichte toekomstverkenning

Deel 2: Een verruiming van perspectief (1983)

Waarborgen voor zekerheid. Een nieuw stelsel van sociale zekerheid in hoofdlijnen (1985)

Basisvorming in het onderwijs (1986)

De onvoltooide Europese integratie (1986)

Ruimte voor groei. Kansen en bedreigingen voor de Nederlandse economie in de komende tien jaar (1987)

Op maat van het midden- en kleinbedrijf (1987)

Deel 1: Rapport aan de Regering;

Deel 2: Pre-adviezen 


\section{Vierde raadsperiode (1988-1992)}

Activerend arbeidsmarktbeleid (1987)

Rechtshandhaving (1988)

Allochtonenbeleid (1989)

Van de stad en de rand (1990)

Technologie en overheid (1990)

De onderwijsverzorging in de toekomst (1991)

\section{Vijfde raadsperiode (1993-1997)}

Duurzame risico's. Een blijvend gegeven (1994)

Besluiten over grote projecten (1994)

47 Hoger onderwijs in fasen (1995)

De financiering van de Europese Gemeenschap. Een interimrapport (1987)

Overheid en toekomstonderzoek. Een inventarisatie (1988)

Een werkend perspectief. Arbeidsparticipatie in de jaren '90 (1990)

Milieubeleid. Strategie, instrumenten en handhaafbaarheid (1992)

Grond voor keuzen. Vier perspectieven voor de landelijke gebieden in de Europese Gemeenschap (1992)

Ouderen voor ouderen. Demografische ontwikkelingen en beleid (1993)

Belang en beleid. Naar een verantwoorde uitvoering van de werknemersverzekeringen (1994)

48 Stabiliteit en veiligheid in Europa. Het veranderende krachtenveld voor het buitenlands beleid (1995)

Orde in het binnenlands bestuur (1995)

$50 \quad$ Tweedeling in perspectief (1996)

51 Van verdelen naar verdienen. Afwegingen voor de sociale zekerheid in de 21e eeuw (1997)

52 Volksgezondheidszorg (1997)

53 Ruimtelijke-ontwikkelingspolitiek (1998)

54 Staat zonder land. Een verkenning van bestuurlijke gevolgen van informatie- en communicatietechnologie (1998)

\section{Zesde raadsperiode (1998-2002)}

Generatiebewust beleid (1999)

Doorgroei van arbeidsparticipatie (2000)

Ontwikkelingsbeleid en goed bestuur (2001)

Naar een Europabrede Unie (2001)

60 Nederland als immigratiesamenleving (2001)

61 Van oude en nieuwe kennis. De gevolgen van ICT voor het kennisbeleid (2002)

62 Duurzame ontwikkeling: bestuurlijke voorwaarden voor een mobiliserend beleid (2002)

63 De toekomst van de nationale rechtsstaat (2002)

64 Beslissen over biotechnologie (2003)

65 Slagvaardigheid in de Europabrede Unie (2003)

66 Nederland handelsland. Het perspectief van de transactiekosten (2003)

67 Naar nieuwe wegen in het milieubeleid (2003) 


\section{Zevende raadsperiode (2003-2007)}

Waarden, normen en de last van het gedrag (2003)

De Europese Unie, Turkije en de islam (2004)

71 Focus op functies. Uitdagingen voor een toekomstbestendig mediabeleid (2005)

72 Vertrouwen in de buurt (2005)

Rapporten aan de Regering nrs $1 \mathrm{t} / \mathrm{m} 67$ en publicaties in de reeks Voorstudies en achtergronden zijn niet meer leverbaar. Vanaf begin 2005 zijn alle studies van de WRR beschikbaar via de website www.wrr.nl.

Rapporten aan de Regering nrs $68 \mathrm{t} / \mathrm{m} 72$ zijn verkrijgbaar in de boekhandel of via Amsterdam University Press, Prinsengracht 747-751, 1017 JX Amsterdam (www.aup.nl). 


\section{VERKENNINGEN}

\section{Zevende raadsperiode (2003-2007)}

1 Jacques Pelkmans, Monika Sie Dhian Ho en Bas Limonard (red.) (2003) Nederland en de Europese grondwet

2 P.T. de Beer en C.J.M. Schuyt (red.) (2004) Bijdragen aan waarden en normen

3 G. van den Brink (2004) Schets van een beschavingsoffensief. Over normen, normaliteit en normalisatie in Nederland

4 E.R. Engelen en M. Sie Dhian Ho (red.) (2004) De staat van de democratie. Democratie voorbij de staat

5 P.A. van der Duin, C.A. Hazeu, P. Rademaker en I.J. Schoonenboom (red.) (2004) Vijfentwintig jaar later. De Toekomstverkenning van de WRR uit 1977 als leerproces

6 H. Dijstelbloem, P.L. Meurs en E.K. Schrijvers (red.) (2004) Maatschappelijke dienstverlening. Een onderzoek naar vijf sectoren

7 W.B.H.J. van de Donk, D.W.J. Broeders en F.J.P. Hoefnagel (red.) (2005) Trends in het medialandschap. Vier verkenningen.

Verkenningen nrs $1 \mathrm{t} / \mathrm{m} 7$ zijn verkrijgbaar in de boekhandel of via Amsterdam University Press, Prinsengracht 747-751, 1017 JX Amsterdam (www.aup.nl). 


\section{VOORSTUDIES EN ACHTERGRONDEN}

Hieronder worden de publicaties uit de WRR-serie Voorstudies en achtergronden opgesomd vanaf de vijfde raadsperiode. Een volledig overzicht van de voorstudies is beschikbaar op de WRR-website (http://www.wrr.nl) of aan te vragen bij het bureau van de WRR (070 - 3564625$)$.

Vijfde raadsperiode (1993-1997)

\section{Zesde raadsperiode (1998-2002)}

V104 implicaties voor beleid arbeid het behoud daarvan

J. Rupnik e.a. (1995) Challenges in the East oudedagsvoorziening Health Care

binnenlands bestuur Nederlandse arbeidsverhoudingen

J.P.H. Donner (1998) Staat in beweging

W.J. Dercksen e.a. (1993) Beroepswijs onderwijs. Ontwikkelingen en dilemma's in de aansluiting van onderwijs en

W.G.M. Salet (1994) Om recht en staat. Een sociologische verkenning van sociale, politieke en rechtsbetrekkingen J.M. Bekkering (1994) Private verzekering van sociale risico's

C. Lambers, D.A. Lubach, M. Scheltema (1994) Versnelling juridische procedures grote projecten СSнОВ (1995) Aspecten van hoger onderwijs. Een internationale inventarisatie

T. van der Meij e.a. (1995) Ontwikkelingen in de natuur. Visies op de levende natuur in de wereld en scenario's voor

L. Hagendoorn e.a. (1995) Etnische verhoudingen in Midden- en Oost-Europa

H.C. Posthumus Meyjes, A. Szász, Christoph Bertram, W.F. van Eekelen (1995) Een gedifferentieerd Europa

J.P.H. Donner (rapporteur) (1995) Europa, wat nu?

R.M.A. Jansweijer (1996) Gouden bergen, diepe dalen: de inkomensgevolgen van een betaalbare

W. Derksen, W.A.M. Salet (red.) (1996) Bouwen aan het binnenlands bestuur

SEO/Intomart (1996) Start-, slaag- en faalkansen van hoger opgeleide startende ondernemers

L.J. Gunning-Schepers, G.J. Kronjee and R.A. Spasoff (eds.) (1996) Fundamental Questions about the Future of

H.B.G. Ganzeboom en W.C. Ultee (red.) (1996) De sociale segmentatie van Nederland in 2015

M.F. Gelok en W.M. de Jong (1997) Volatilisering in de economie

A.H. Kleinknecht, R.H. Oostendorp, M.P. Pradhan (1997) Patronen en economische effecten van flexibiliteit in de ecologische en maatschappelijke risico's in confrontatie en dialoog

W. Zonneveld en A. Faludi (1998) Europese integratie en de Nederlandse ruimtelijke ordening

Verslag en evaluatie van de vijfde raadsperiode (1998)

W. Derksen et al. (1999) Over publieke en private verantwoordelijkheden

Henk C. van Latesteijn (1999) Land use in Europe. A methodology for policy-oriented future studies

Aart C. Liefbroer en Pearl A. Dykstra (2000) Levenslopen in verandering. Een studie naar ontwikkelingen in de levenslopen van Nederlanders geboren tussen 1900 en 1970 
V108 Bart Wissink (2000) Ontworpen en ontstaan. Een praktijktheoretische analyse van het debat over het provinciale omgevingsbeleid

V109 H. Mommaas, m.m.v. W. Knulst en M. van den Heuvel (2000) De vrijetijdsindustrie in stad en land. Een studie naar de markt van belevenissen

V110 H. Dijstelbloem en C.J.M. Schuyt, red. (2002) De publieke dimensie van kennis

V111 M.C.E. van Dam-Mieras en W.M. de Jong, red. (2002) Onderwijs voor een kennissamenleving. De rol van ICT nader bekeken

V112 Wendy Asbeek Brusse, Harry van Dalen en Bart Wissink (2002) Stad en land in een nieuwe geografie. Maatschappelijke veranderingen en ruimtelijke dynamiek

V113 G.A. van der Knaap (2002) Stedelijke bewegingsruimte. Over veranderingen in stad en land.

V114 F.J.P.M. Hoefnagel (2002) Internet en cultuurbeleid. Over de gevolgen van ICT voor het cultuurbeleid van de Nederlandse overheid

V115 Gabriël van den Brink (2002) Mondiger of moeilijker? Een studie naar de politieke habitus van hedendaagse burgers

V116 Willem Witteveen, Bart van Klink, met bijdragen van Wouter de Been en Peter Blok (2002) De sociale rechtsstaat voorbij. Twee ontwerpen voor het huis van de rechtsstaat

V117 Rein de Wilde, Nikki Vermeulen en Mirko Reithler (2003) Bezeten van genen. Een essay over de innovatieoorlog rondom genetisch gemodificeerd voedsel

\section{Overige publicaties}

Voor de eenheid van beleid. Beschouwingen ter gelegenheid van vijftig jaar Ministerie van Algemene Zaken (1987)

Eigentijds burgerschap. WRR-publicatie onder leiding van H.R. van Gunsteren (1992)

Mosterd bij de maaltijd. 20/25 jaar WRR (1997)

De vitaliteit van de nationale staat in een internationaliserende wereld (2002) 


\section{Sociale herovering in Amsterdam en Rotterdam}

Wat zijn de grenzen en mogelijkheden van stedelijke gebieden om zichzelf te vernieuwen en te verbeteren? Duidelijk is dat een belangrijke rol bij dit zelfvernieuwend potentieel wordt gespeeld door de buurt. Als het sociale potentieel dat op kleinschalige niveaus aanwezig is voldoende ruimte en ruggesteun krijgt bij de aanpak van problemen die van invloed zijn op de leefbaarheid, doet de buurt ertoe. Er bestaat echter wel een grote variëteit in buurten en problematiek. Veel achterstandsbuurten, zoals de Overtoomse Veld in Amsterdam en de Tarwewijk in Rotterdam, kennen hardnekkige en omvangrijke problemen waardoor die buurten zonder gerichte aandacht en ondersteuning niet of moeilijk op eigen kracht de probleemspiralen kunnen doorbreken. In dit soort buurten past een strategie van 'sociale herovering', dat wil zeggen: een massieve inzet van alle betrokkenen om de leefbaarheid te verbeteren.

Ter onderbouwing van de specifieke problematiek van achterstandsbuurten in de grote steden heeft de WRR in het kader van haar rapport Vertrouwen in de buurt een onderzoek laten uitvoeren door prof. Engbersen, prof. Snel en mw. Weltevrede (Erasmus Universiteit Rotterdam en de Universiteit van Twente). Deze verkenning, Sociale herovering in Amsterdam en Rotterdam, omvat het verslag van dit onderzoek. 